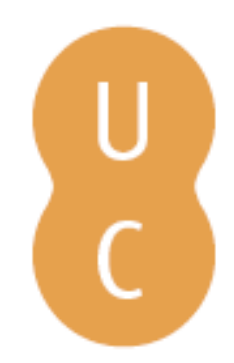

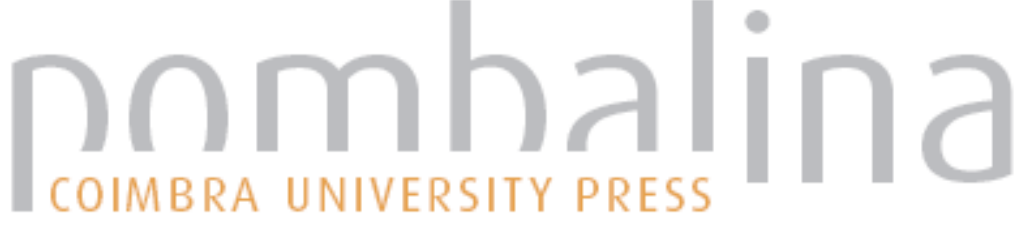

\section{Aprofundar a crise: olhares multidisciplinares}

Autor(es): $\quad$ Peixinho, Ana Teresa; Camponez, Carlos; Sá, Alexandre

Publicado por: Imprensa da Universidade de Coimbra

URL

persistente: URI:http://hdl.handle.net/10316.2/5676

DOI: $\quad$ DOI:http://dx.doi.org/10.14195/978-989-26-0574-6

Accessed : $\quad$ 28-Sep-2017 14:52:47

A navegação consulta e descarregamento dos títulos inseridos nas Bibliotecas Digitais UC Digitalis, UC Pombalina e UC Impactum, pressupõem a aceitação plena e sem reservas dos Termos e Condições de Uso destas Bibliotecas Digitais, disponíveis em https://digitalis.uc.pt/pt-pt/termos.

Conforme exposto nos referidos Termos e Condições de Uso, o descarregamento de títulos de acesso restrito requer uma licença válida de autorização devendo o utilizador aceder ao(s) documento(s) a partir de um endereço de IP da instituição detentora da supramencionada licença.

Ao utilizador é apenas permitido o descarregamento para uso pessoal, pelo que o emprego do(s) título(s) descarregado(s) para outro fim, designadamente comercial, carece de autorização do respetivo autor ou editor da obra.

Na medida em que todas as obras da UC Digitalis se encontram protegidas pelo Código do Direito de Autor e Direitos Conexos e demais legislação aplicável, toda a cópia, parcial ou total, deste documento, nos casos em que é legalmente admitida, deverá conter ou fazer-se acompanhar por este aviso. 


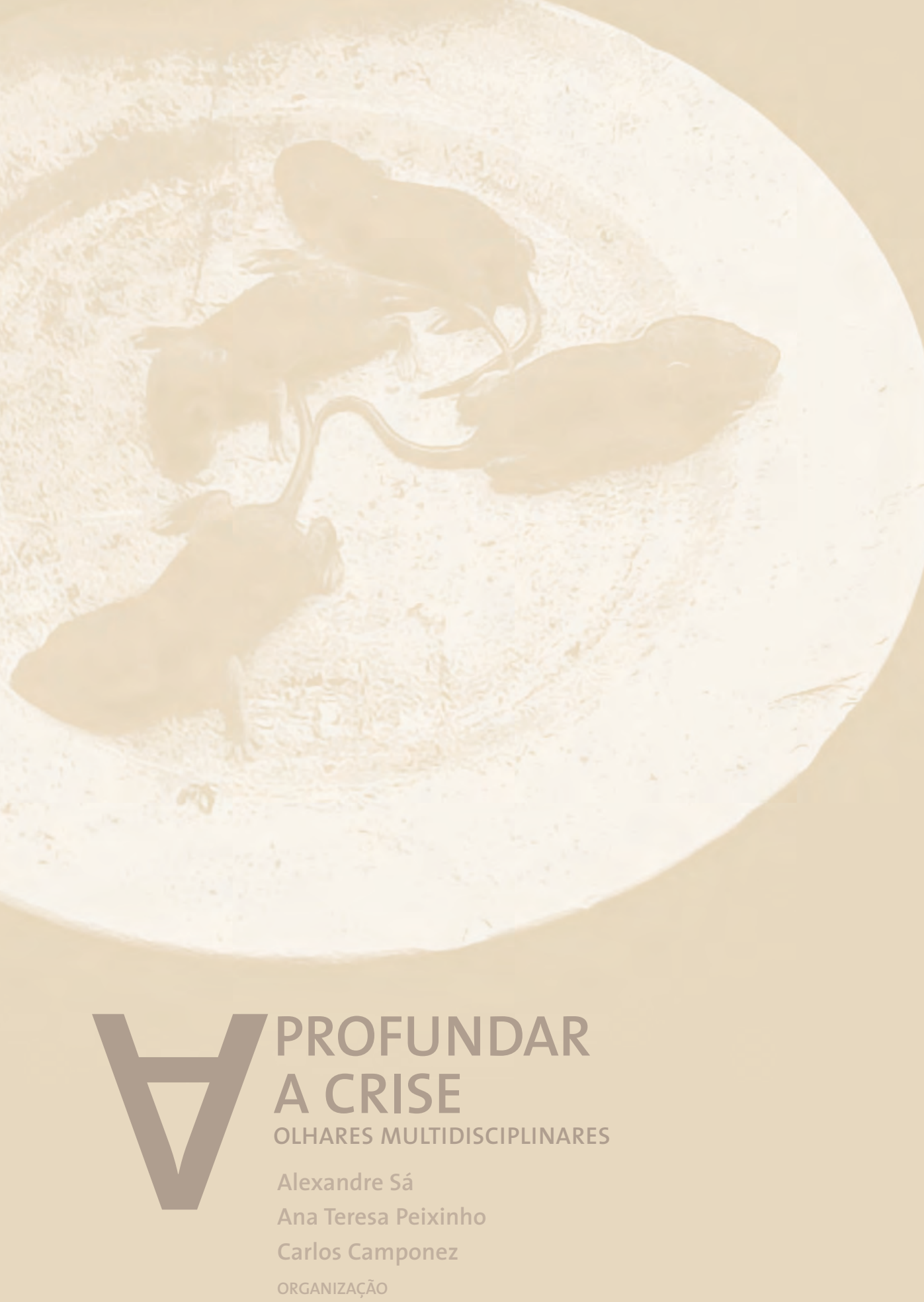


(Página deixada propositadamente em branco) 


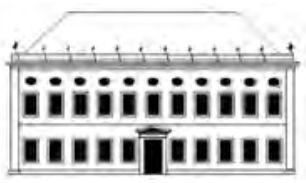

D

0

C

U

E

N

0

S

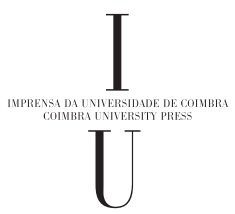




\section{EDIÇÃO}

Imprensa da Universidade de Coimbra

URL: http://www.uc.pt/imprensa_uc

Email: imprensauc@ci.uc.pt

Vendas online: http://www.livrariadaimprensa.com

\section{CONCEÇÃO GRÁFICA}

António Barros

INFOGRAFIA DA CAPA

Carlos Costa

\section{INFOGRAFIA}

Xavier Gonçalves

EXECUÇÃO GRÁFICA

wWw.artipol.net

IS BN

978-989-26-0149-6

ISBN Digital

978-989-26-0574-6

DOI

http://dx.doi.org/10.14195/978-989-26-0574-6

DEPÓSITO LEGAL

$347417 / 12$

OBRA PUBLICADA COM O APOIO DE:
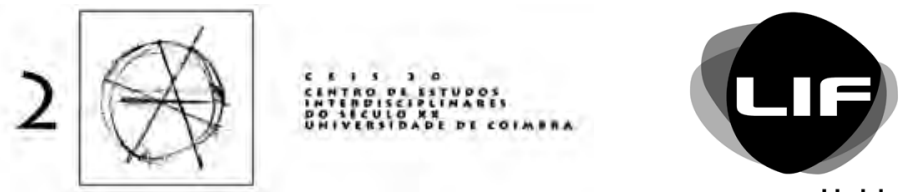

Unidade de I\&D

LINGUAGEM

INTERPRETAÇÃO

FILOSOFIA

\section{FCT Fundação para a Ciência e a Tecnologia MINISTÉRIO DA CIENCIA, TECNOLOGIA E ENSINO SUPERIÓR Portugal}

Programa Operacional Tecnologia Inovação do Quadro Comunitário de Apoio III 


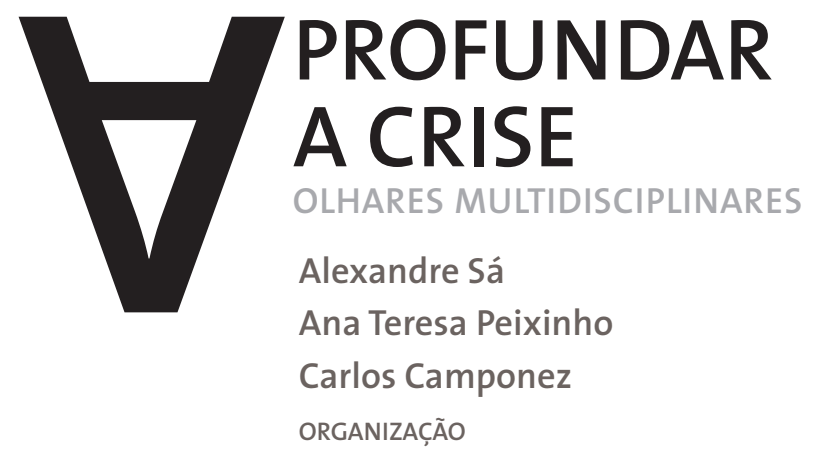

IMPRENSA DA UNIVERSIDADE DE COIMBRA 
(Página deixada propositadamente em branco) 


\section{Sumário}

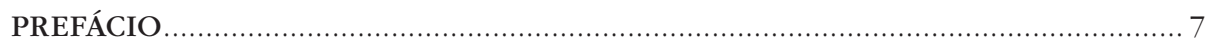

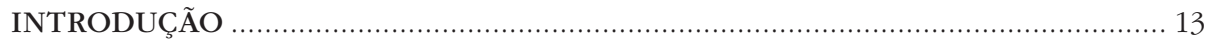

A CRISE VISTA PELA FILOSOFIA

CONTRIBUTOS PARA UMA HERMENÊUTICA DA CRISE. 23

Maria Luísa Portocarrero

DA CRISE DA REPÚBLICA À REPÚBLICA DA CRISE ........................................ 41

Alexandre Franco de Sá

CRISE E SENTIDO

Luís António Umbelino

TEM O DIAGNÓSTICO FENOMENOLÓGICO

DA CRISE UMA LEITURA POLÍTICA?.

Pedro M. S. Alves

CRISE NOS E DOS MEDIA

ELEGIAS DA CULTURA NA ERA DA INTERNET 93

António Fidalgo

A CRISE DA NORMALIZAÇÃO DA “CRISE»: OU A COMUNICAÇÃO DESCONTINUADA POR EXAUSTÃO SIMBÓLICA DA LINGUAGEM 105 João Pissarka Esteves 
CRISE, CORRUPÇÃO POLÍTICA E MEDIA

IsABel Ferin Cunha

O SOM DO SILÊNCIO: A QUESTÃO DA VOZ NAS SOCIEDADES NEOLIBERAIS EM CRISE

Maria Jỗo Silveirinha

JORNALISMO: O FRACASSO DE UM CONTRAPODER ENTRE PODERES 159

Carlos Camponez

A NARRATIVA COMO SUPERAÇÃO DA CRISE 175

Ana Teresa Peixinho

A PEGADA JORNALÍSTICA NA PAISAGEM MEDIÁTICA 193 JoÃo FigueIRA

ECONOMIA E CRISE

A CRISE ATUAL DO CAPITALISMO: CRISE ESPERADA

E QUASE PROGRAMADA

AnTÓNIO José AvelÃs NunEs

AUX ORIGINES DE LA CRISE FINANCIÈRE .253

Alain de Benoist

ÍNDICE ONOMÁSTICO 263 
José Reis

FEUC - CES

\section{Prefácio}

Parece claro que vivemos um momento raro em que a elaboração conceptual e a problematização teórica têm um papel crucial, irrevogável, no debate de ideias. E, no entanto, os conceitos centrais e as noções fundamentais aparentam estar tão sujeitos como tudo o mais a uma tormenta que os desafia, delapida ou desconstrói. É certo que nestas circunstâncias há encontros previstos. Geralmente, são os inquietos que se encontram, ansiosamente. São os que carregam consigo pequenos patrimónios a que persistem em dar valor e os que querem refazer os mapas que lhes descrevam os caminhos e lhes viabilizem sentidos. São os que apenas procuram compreender, mesmo que de forma parcial, limitada, humilde. As crises parece que só oferecem espaço para a afirmação de compreensões totais aos que as ignoram, aos que insistem em "procurar ativamente esconder". Os outros, ao contrário, fixam-se essencialmente em tensões a que tentam deslindar as forças e os significados. E não desistem de tentar a perceção da complexidade.

Quer isto dizer que um dos primeiros terrenos para onde converge a inquietação é aquele onde já se plantou a recusa de fazer da "pura sistemática" ou da "pura transparência" instrumentos para analisar ou representar um mundo que é essencialmente impuro, feito de contingências, refrações, obscuridades, continuidades valiosas e roturas significativas. Este é, aliás, o primeiro patamar onde eu, um economista que se prende à corrente da vida e às interrogações sobre o que está em aberto, se encontrou fraternalmente com os problemas e os debates deste livro. A Economia que desapossou o conhecimento económico da perceção da história, da valia dos quadros culturais e institucionais, da intencionalidade dos atores e das tensões próprias da sociabilidade, a Economia que reduziu o conhecimento económico a uma sistemática pavloviana sobre reações 
gélidas a incentivos ou a uma mecânica de lógicas supostamente naturalistas que antecedem os indivíduos e a organização coletiva (os "mercados"), essa Economia é o reverso da capacidade de encarar o mundo através do conhecimento problemático, tenso, porventura apenas provisório. Um conhecimento que valorize as tensões mas também a incerteza, a disputa, os desequilíbrios próprios do conflito e a deliberação que viabiliza os processos sólidos, mesmo os que não alcançam consensos.

Por estas razões, o segundo patamar onde um economista como eu se encontra com os outros cientistas sociais que escrevem neste livro é evidentemente aquele onde a própria noção de crise se revela e se oferece à discussão. Estamos todos longe dos lugares folclóricos onde se substitui o mundo público e político pelo dos saberes autistas, das soluções "inevitáveis", das trajetórias "obrigatórias", do papel sapiente e autoritário dos que "reorientam" a vida daqueles que se "desviam", cometem "excessos", andam "além das suas possibilidades", ignoram o "padrão" dos comportamentos "certos". Para os que ocupam esses lugares, a "crise" é apenas isso, é um processo "técnico" que a vulgaridade exprime através da noção arbitrária de que "se faz o que tem de ser feito", dizendo-se isso da forma compulsiva que serve para esconder a violência ideológica, tanto a consciente como a ignorante de si mesma. Ao contrário, habituámo-nos à historicidade, à complexidade, à construção de ordens coletivas através da deliberação, à revisão dessas ordens através de processos igualmente históricos ou do surgimento de contingências fundamentais, ambos assentes em decisões que marcam instantes, momentos radicais e originais de separação e rotura, com os quais se definem novas clarificações que são tanto fruto como origem da mudança e da transformação.

Mas, ao dizer-se isto, abre-se a porta para a maior das perplexidades, aquela para que já apontei acima, quando falei da tormenta a que os próprios conceitos estão sujeitos. Basta-nos hoje, basta-nos para os dias que vivemos, o conceito de crise que convocamos a cada momento? O refinamento do seu conteúdo, feito com clareza e abundância neste livro, assim como a alusão à hermenêutica e à exuberância das situações sociais que já conhecemos do passado, não nos demonstrarão que o conceito nos serve para quando as crises-foram-realmente-crises, revelando-nos agora que até o conceito de crise nos abandonou no ermo da crise-da-crise, deixando-nos desapossados num contexto a que parece que já 
foram subtraídos os seus elementos essenciais? A crise como "instante fugaz" de rotura, de "clarificação, de "abertura a um futuro", de separação de tempos mas não de separação das bases da vida digna condiz com os dias de hoje? Não terá a disputa que justifica a deliberação, não terá a transformação que proporciona o futuro, não terá a fenomenologia que dá substância ao processo da vida, não terá aquilo que nos oferece a possibilidade de agir e de exercer as próprias circunstâncias das crises sido expulso do espaço público e político, que é aquele onde, através do comprometimento, se resolvem as crises-que-são-crises? A crise como ideia e lugar de avanços, como "horizonte de espera", será compatível com um tempo sistemático de desligamentos, de retrocessos, de desconstruções, de subtrações ao campo do visível e de remissões de muito do que nos capacitava ("o espaço da experiência") para os espaços reservados da obscuridade? Isto para já não falar da tentação fácil de localizar a crise, designando-a financeira ou referindo-a apenas aos "mercados", entidades que não se define, porventura para não se dar conta de que o que existe e nos oprime nada tem a ver com a ideia trivial, quanto mais com a noção, de mercados.

Talvez, então, perdendo-se quer o significado transformador, deliberativo, das crises, quer a mais ampla erudição conceptual que a marcou, a noção de crise resista e subsista como simples patologia, bloqueamento "claustrofóbico" que desfez as sequências do tempo, gerando um "abismo entre o realizado e o realizável”. Nesse caso, o conhecimento (tanto o dos filósofos como o dos economistas) está tão desapossado que só pode ambicionar em reconstruir-se rapidamente. É certo que, com essa consciência, esses desapossados ainda possuem uma vantagem significativa: têm a noção do tempo e a herança dos que os precederam (os clássicos de todas as disciplinas). E têm o sentido da crítica e da sua capacidade construtiva. Assim como têm a intuição do campo para onde se devem dirigir.

É aqui que entra a outra dimensão deste livro, a que se junta à sabedoria dos filósofos, a que nos fala do espaço público e político, das estruturas comunicacionais, da construção de sentidos, dos modelos de comunicação. São estes os campos e os lugares que não se podem dispensar, quando se estima que o conhecimento não precisa apenas de se afirmar, precisa também de se refazer construtivamente, em debate, nos espaços da vida, no fórum. Um conhecimento "republicano", porventura. E aqui chego ao terceiro grande patamar onde 
um economista que encara a Economia como Economia Política se reconhece confortavelmente. Como os jornalistas de um tipo preciso de jornalismo que regressaram à voz das pessoas, que descreveram as "cenas" onde essa voz se ouve e onde se desenrola a ação, assim os economistas políticos não prescindem das grandes narrativas, assumindo-as como meio de uma inteligibilidade mais rigorosa e de acesso a um lugar onde, nas atuais circunstâncias, é importante estar para criar sentido - a polis, a arena pública, o espaço da (discussão sobre a) deliberação coletiva. O que nos encaminha para tais lugares é, porventura, o valor da história e a ambição de retirar das obscuridades tudo o que lá foi colocado depois de subtraído às pessoas, à política, ao espaço público. Mas é também a noção de que o conhecimento mais sólido se constrói e reconstrói por estes caminhos.

Não se ignora, no entanto, que o lugar público não está reservado para esta agenda e que outros identificaram atempadamente o seu valor. E que, por isso, as relações são assimétricas, sistematicamente tensas, talvez estruturalmente desequilibradas. O significado crítico e voluntarioso incluído na ideia de hegemonia foi devidamente apropriado por quem age segundo interesses estreitos, com a finalidade precisa de colocar silêncios onde deviam estar vozes. A "voz", que Albert Hirschman pôs ao lado da dissidência (exit) e do empenhamento cúmplice (loyality) como modo de relacionamento com organizações ou processos políticos, é evidentemente condição da participação e da deliberação democrática e a sua "crise" é a da própria possibilidade de democracia e a expressão da perda de memória. Antes disso está, no entanto, uma "estrutura simbólica de comunicação pública" que destituiu a comunicação de algumas das suas condições essenciais e a subordinou, operando descontinuações que até os universitários hoje em dia conhecem bem no seu próprio meio, pois são parte de uma lógica geral de normalização que orienta a própria produção dos saberes académicos, cada vez mais descontínua, fragmentária, desligada de preceitos que não sejam os da simples individualização e reconhecimento "tribal".

Cada disciplina confronta-se, é certo, com os seus limites e dilemas. Mas é no campo transdisciplinar que os cientistas sociais fixam os locais de encontro das questões mais substantivas e mais emancipadoras com que trabalham e com que buscam soluções ou, pelo menos, caminhos. A Economia é hoje uma das disciplinas que maiores perplexidades suscita. Não é apenas pela falta de 
capacidades que os seus discursos dominantes encerram ou pelas soluções que eles não são capazes de formular - é pela redução violenta, rude, a que submete a definição e a interpretação dos problemas essenciais. Como todos os campos são incontornavelmente plurais, mesmo quando não existe pluralismo, os que ambicionam o debate e as vantagens da complexidade sabem, em geral, para onde se devem dirigir. É para o campo privilegiado da troca de saberes e da construção cúmplice de problemáticas comuns, assentes em preocupações partilhadas e em objetivos abertos.

Este livro, com que estive a relacionar-me num envolvimento de quem privilegiou as convergências mais sedutoras, é de enorme importância e os contributos que regista são dos mais desafiadores. Como comecei por dizer, há sempre, nas circunstâncias difíceis, encontros previstos. Para mim, este é um deles, paralelo em significado a tudo o que possui a vitalidade que transborda os limites, quaisquer que sejam, em que nos possamos encerrar. É com o elogio da confluência dos debates e da turbulência das ideias que eu, beneficiário da intensidade deste livro, termino. 
(Página deixada propositadamente em branco) 


\section{INTRODUÇÃO}

O caráter intrinsecamente interdisciplinar do conceito de "crise" começa logo na sua etimologia. Crise remete para crítica: o verbo grego krinein significa julgar e, nesse sentido, decidir, cortar, separar, cindir, estabelecer diferenças. Todavia, a cisão só ocorre, a diferença só se estabelece, entre aquilo que tem relação. A relação que a cisão crítica exige aponta, então, para o contacto entre análises diferenciadas, por cujo cruzamento se possa desenvolver uma compreensão mais original - mais originária e, neste sentido, mais crítica - dos temas tratados.

Há, contudo, também um sentido mais óbvio em que a interdisciplinaridade do tema da crise pode ser surpreendida. Tal sentido deriva do próprio conteúdo imediato do fenómeno para o qual este tema aponta. Por um lado, em certo sentido, poderíamos dizer que a vida fática do homem no mundo é perpassada pela crise. Uma vida humana não se reduz ao simples facto de se viver: existir humanamente significa já habitar uma "crise", ser perturbado pelo enigma da existência. Por outro lado, numa outra aceção, o nosso tempo, a "era comunicacional" e a "era da informação", é também, mais do que nunca, especificamente, um tempo de crises: crise social, crise de valores, crise educacional, crise política, crise económica, crise financeira. Os contributos que as ciências da comunicação podem dar para a compreensão profunda destas crises são aqui decisivos, sobretudo quando em diálogo com perspetivas filosóficas de abordagem destes fenómenos.

Colhendo esta multiplicidade de sentidos que o tema da crise nos disponibiliza, o presente livro pretende dar lugar precisamente a uma variedade de abordagens que ecoa esta multiplicidade de sentidos. É com este propósito que se tem em vista aprofundar a crise. Este aprofundamento é, aliás, essencial para 
o debate fundado não apenas dos problemas, mas também das soluções. Talvez este aprofundamento da crise se possa colocar sob o mote de um verso do poeta Hölderlin, muitas vezes citado por autores filosóficos: "Só onde está o perigo é que também cresce o que salva”.

Neste sentido, o presente livro teve a sua origem num colóquio organizado pelo Departamento de Filosofia, Comunicação e Informação, no passado mês de março de 2011, que reuniu um conjunto de académicos de áreas científicas muito diferenciadas, para, em conjunto e sempre numa perspetiva de questionamento coletivo e interdisciplinar, refletir sobre esta pluralidade de sentidos que o conceito «crise» convoca. A partir da reflexão desencadeada nesse evento e dada a qualidade das intervenções, entendemos levar a público estes contributos, abrindo a discussão a outros autores.

O livro organiza-se em três secções temáticas que correspondem a três diferentes perspetivas de abordagem da crise: a filosófica, a da comunicação e, naturalmente, a económica. O primeiro momento - A Crise Vista pela Filosofia - inicia-se com um texto de Maria Luísa Portocarrero. Escrevendo sobre os Contributos para uma hermenêutica da crise, esta estudiosa questiona o pano de fundo espiritual, histórico e filosófico da nossa situação atual. Partindo do horizonte teórico da hermenêutica e cruzando as reflexões de historiadores como Tony Judt e de filósofos como Hannah Arendt e Paul Ricoeur em torno da situação epocal do século xx, a autora procura encontrar, na problemática hermenêutica da relação entre tradição e crise, a fonte que permite compreender a crise atual num plano mais profundo e complexo. A matriz hermenêutica da sua abordagem conduz Maria Luísa Portocarrero a situar uma tal crise no horizonte da filosofia prática, compreendendo-a à luz de uma exigência ética de compromisso e como ocasião para uma reinterpretação das grandes heranças da tradição.

Partindo de um quadro teórico semelhante no plano da hermenêutica, Luís Umbelino, escrevendo sobre Crise e Sentido, interroga-se sobre os critérios pelos quais somos levados a caracterizar determinado estado, contexto, situação ou período como sendo "de crise". A partir desta questão, sugere-se que, para se entender determinada situação fora de nós e à nossa volta como "crise", é forçoso que encontremos primeiro "em nós" um modelo interior que permita, por analogia, viver, experimentar e compreender como crise determinado estado de coisas. É para esta correspondência analógica que se procura remeter, a partir 
de uma confrontação com os pensamentos de Maine de Biran, Paul Ricoeur e Innerarity.

Num texto intitulado Da Crise da República à República da Crise, Alexandre Franco de Sá procura aproximar uma abordagem histórico-filosófica da crise em geral da realidade concreta da crise portuguesa. Partindo de reflexões acerca da cultura e da política portuguesas como as de José Gil, ao descrever Portugal como um país em que nada acontece, Alexandre Franco de Sá interroga-se sobre a história de Portugal nos últimos cem anos, em busca do fundamento para um tal diagnóstico. Este horizonte de questionamento e uma abordagem do fenómeno político, em que se cruzam as influências de Carl Schmitt e de Hannah Arendt, permitem uma visão panorâmica do percurso da República Portuguesa, e das suas crises, ao longo dos seus cem anos de vida.

Na secção desta obra, dedicada à Crise dos e nos Media, os autores e autoras tentam decifrar o sentido atual da crise nos media: até que ponto estes são afetados por esta ideia global de crise e, por outro lado, de que formas o discurso mediático recoloca no espaço público a temática da crise. Inaugurando esta secção, António Fidalgo, ao escrever sobre Elegias da Cultura na Era da Internet, situa o tema da crise no plano de uma reflexão sobre os novos meios de informação, particularmente a internet. Partindo de reflexões críticas já clássicas, em torno do efeito da televisão no plano da cultura e da educação, como as de Neil Postman, António Fidalgo confronta-se com as reflexões de autores como Sven Birkerts e Nicholas Carr em torno da internet e das perplexidades que ela não pode deixar de suscitar. O contraste entre a leitura demorada de um livro e a leitura saltitante potenciada pela internet, assim como a hipótese de Carr de que a internet terá como efeito a perda de capacidade de atenção, memória e concentração no cérebro humano, conduzem António Fidalgo à reflexão sobre a possibilidade de compreender tais efeitos em analogia com a perda, pela obra de arte, da sua "aura" naquilo a que Walter Benjamin chamou a era da sua reprodutibilidade técnica.

Numa perspetiva diferente, em A Crise da Normalização da "Crise»: sobre a comunicação descontinuada por exaustão simbólica da linguagem, João Pissarra Esteves aborda os media, enquanto potenciais focos de crise, divididos entre uma ética e moral da comunicação e a sua funcionalização sistémica. Adotando um ponto de vista diacrónico, sem, no entanto, deixar de refletir sobre a emergência 
dos chamados "novos media", este autor sublinha o fosso criado, no seio da comunicação pública, entre produção e receção, fratura que arrasta consigo problemas éticos e morais, atualmente potenciados pelo aparato tecnológico que amplifica os efeitos simbólicos dos media. Contudo, para Pissarra Esteves, quer nos antigos media, quer nos novos, a questão candente é a da cisão que existe entre as exigências intercompreensivas, por um lado, e performatividade funcional, por outro. O final do texto deste autor é bem sintomático quanto à complexidade desta questão: terminando com uma pergunta - à qual foi conduzido pelo raciocínio desenvolvido - Pissarra Esteves convoca a nossa atenção para uma nova reflexão: aquela que abordará a "teologia dos media".

Maria João Silveirinha, em O som do silêncio: a questão da voz nas sociedades neoliberais em crise, parte da pista de diversos autores contemporâneos na sua leitura da crise financeira contemporânea, para quem o foco na procura dos responsáveis pelo problema, minimizando o contexto mais vasto cultural e político que lhe deu forma, tende a levar a soluções excessivamente rápidas e aparentemente simples, deixando intocado o modo como esta mesma crise é usada para impor duras medidas de "ajuste estrutural», que reforçam o sistema e nos impedem de projetar outros imaginários políticos viáveis do futuro. Na busca de pistas que nos coloquem no encalço desses novos imaginários, a autora parte do contexto neoliberal, analisando criticamente alguns dos momentos-chave que impuseram a doutrina neo-liberal. Termina a análise, considerando que a crise económica contemporânea não é apenas a voragem economicista das nossas reivindicações culturais, mas também uma verdadeira crise de voz que não se faz escutar. Ouvir, aqui, constitui-se como o ato radical de reconhecer que alguém tem algo a dizer, que é capaz de gerar outras narrativas de si mesmo e dos seus projetos humanos, isto é, a adotar perspetivas morais que garantam as condições sociais do reconhecimento e do respeito por todos os outros, pelo amor, igualdade e solidariedade.

Já Isabel Ferin Cunha, no seu texto Crise, Corrupção Política e Media, visa discutir as relações entre estes conceitos, tentando perceber que representações dos fenómenos de corrupção são construídas pelos media portugueses. No artigo, utiliza-se ainda uma estratégia que pretende cotejar definições conceptuais e a revisão de literatura com as representações da crise e da corrupção política nos meios de comunicação em Portugal. 
Numa outra perspetiva, Ana Teresa Peixinho e João Figueira dedicam duas reflexões à crise no jornalismo, tentando perceber vias de superação da crise que afeta o panorama jornalístico português. Segundo a primeira autora, o jornalismo pode encontrar um último reduto, caso decida fazer um exercício retrospetivo, resgatando algumas das características que tinha nas suas origens. Recuperando, através de uma visão histórica, o importante papel que a imprensa teve ao longo do século xix, Ana Teresa Peixinho defende que uma das soluções possíveis para a crise da imprensa, na atualidade, pode passar por uma revisão do papel dos jornais, mas também por uma abertura destes a novos agentes, e a uma revisão do papel da escrita e da narrativa na construção dos acontecimentos.

Já João Figueira defende que um jornalismo forte é a receita para uma democracia saudável. Segundo este autor, pesem embora as enormes transformações tecnológicas a que temos vindo a assistir nas últimas décadas, os vetores basilares do jornalismo permanecem inalterados: incrementar o debate, fomentar o esclarecimento do público, dinamizar laços sociais. Contudo, reconhece e sublinha que um conjunto de condicionalismos económicos, sociais e culturais têm afastado o jornalismo da sua linha de atuação principal, tornando-o "fraco e dependente".

$\mathrm{Na}$ abordagem económica, três textos críticos tratam questões fundamentais da crise contemporânea, a partir de perspetivas diferentes mas convergentes. Alain Benoist, António José Avelãs Nunes e Carlos Camponez trazem-nos um olhar crítico sobre as consequências que se desenham por detrás das expressões como capitalismo intangível, capitalismo cognitivo, novo capitalismo, ou, de uma forma mais contundente, turbo-capitalismo. De uma forma geral, todas as abordagens põem em evidência as consequências dos efeitos da economia contemporânea, nomeadamente da sua virtualização relativamente à denominada economia real, acabando por desestruturar os processos de organização social e política, cada vez mais enredados no pensamento único neoliberal.

Assim, António José Avelãs Nunes, aborda em filigrana as crises económicas, desde as propostas keinesianas, passando pelos Trinta Gloriosos anos que criaram a ilusão de um capitalismo post-cíclico. Desfeita nos anos 70, a ilusão de um capitalismo sem crises e o regresso da denominada contrarrevolução monetarista, que culminou com a vitória do "capitalismo de casino", parecem dar razão às teses do fascismo amigável e do fascismo de mercado de que já nos anos 80 nos alertavam autores como Bertram, Gross e Paul Samuelson. 
O capitalismo de casino, de que nos fala José António Avelãs Nunes, é o resultado da financeirização da economia e do neoliberalismo assente na especulação em detrimento do capital produtivo, cujas consequências se refletem nos momentos conturbados da crise do euro e da Europa. Porém, como sustenta o autor, o neoliberalismo não é mais do que "O reencontro do capitalismo consigo mesmo, depois de limpar os cremes das máscaras que foi construindo para se disfarçar». Por isso, na sua perspetiva, a atual crise do neoliberalismo - certamente, não a última - representa a crise do próprio capitalismo, pelo que a luta contra a situação que vivemos é entendida como a causa pela própria democracia, por uma "ordem social nova" e por uma profunda alteração das relações internacionais.

A ideia de que a crise económica reflete as próprias contradições do sistema capitalista é retomada por Alain Benoist. O autor salienta que o capitalismo é, ele próprio, sinónimo de crise e se alimenta dela, defendendo que, se a situação económica contemporânea pode não ser mais do que uma fase de uma crise de longa duração, iniciada há 35 anos, ela deve ser também entendida como uma crise estrutural de rutura do próprio sistema. Nestas circunstâncias, mais do que a crise económica, está em causa a crise do próprio regime de acumulação do capital. A dominação dos mercados financeiros, a busca constante de maior lucro, forçando a compressão dos salários, fez com que o consumo fosse sendo estimulado pelo acesso ao crédito fácil, conduzindo ao endividamento massivo e à atual crise que, mais do que económica, é uma crise sistémica. Em face disso, se, em seu entender, a boa notícia talvez fosse que o sistema capitalista está a chegar aos seus últimos dias, a má notícia será certamente a de que esta crise estará longe de terminar.

Ainda na linha desta discussão, outros autores retomam o tema da crise, centrando a sua análise sobre as repercussões sociais e socioprofissionais. Carlos Camponez, retomando Richard Sennett, levanta a questão dos efeitos do capital impaciente na vida dos indivíduos e no seu mundo profissional, questionando uma cultura capitalista que valorizou uma certa forma de realização dos sujeitos, a partir da construção do sucesso do próprio percurso socioprofissional. Passando em revista algumas teses sobre as esperanças anunciadas pela sociedade da informação, o autor defende que, contrariamente ao que se poderia pensar, os processos de desqualificação profissional afetam também os trabalhadores da informação, nomeadamente os jornalistas. A racionalização dos media, proporcionada pela 
novas tecnologias ao serviço de objetivos comerciais e do lucro, começou por se fazer sentir nos anos 70 nas áreas técnicas e de gestão e é hoje uma realidade nas redações, pondo em causa a própria autonomia do jornalismo e dos jornalistas. Desprofissionalização, juvenilização e perda de memória, deslocalização de serviços noticiosos e precariedade profissional são palavras que não podem ser esquecidas no atual contexto de produção de informação. Trata-se de um léxico sem o qual não é possível explicar a atual crise no jornalismo, indissociável das pressões do capital impaciente que busca o lucro e a influência a todo o custo, e que ajuda também a compreender a crise da comunicação e da democracia.

Ana Teresa Peixinho Carlos Camponez Alexandre Franco Sá 
(Página deixada propositadamente em branco) 
A Crise vista pela Filosofia 
(Página deixada propositadamente em branco) 
Maria Luísa Portocarrero

FLUC - LIF

\section{Contributos PARA UMA hermenêutica da CRISE}

Parto com esta comunicação de uma reflexão sobre textos de grandes vultos do séc. xx, um historiador e três filósofos, um deles grande professor desta Faculdade, de modo a efetuar uma hermenêutica da ideia de crise. Os textos em referência são: a introdução a O século xx esquecido. Lugares e memórias de Tony Judt $^{1}$, o artigo "Crise e crítica" de Miguel Baptista Pereira ${ }^{2}$, o texto de P. Ricoeur, "La crise: un phenomène spécifiquement moderne?»3 e o artigo de H. Arendt "A crise na educação"

Começo com Tony Judt, que muito nos faz pensar sobretudo na fragilidade da consciência histórica do Ocidente dos dias hoje. Retenho, nomeadamente, algumas das suas palavras incisivas: "Ao escrever nos anos 90, e novamente a seguir ao 11 de Setembro de 2001, fiquei diversas vezes espantado com essa perversa insistência contemporânea de não perceber o contexto dos nossos dilemas atuais, no país e no estrangeiro; de não escutar com mais atenção algumas das mentes mais sábias das últimas décadas; de procurar ativamente esquecer em vez de lembrar, de em todas as ocasiões possíveis desmentir a continuidade e proclamar a novidade. Isso sempre me pareceu um tanto solipsista. E como os acontecimentos internacionais do princípio do século xxı começaram a dar a entender, também pode ser muito imprudente. O passado recente ainda pode

\footnotetext{
1 TONY JUDT, O século xx esquecido. Lugares e memórias, Lisboa, ed. 70, 2010.

2 MigUEL BAPTISTA PEREIRA, Crise e crítica, in Vértice, (1983) nº XLIII, pp. 100-142.

3 P. RICOEUR, "La crise: un phénomène spécifiquement moderne?, in Revue de théologie et de philosophie, 120 (1988) pp. 1-19

4 HANNAH ARENDT, "A crise da educação", in IDEM, Entre o passado e o futuro. Oito exercícios sobre o pensamento politico, Lisboa, Relógio de Água, 2006, pp. 183-206.
} 
continuar connosco mais alguns anos ${ }^{5}$. No entanto, relembra Judt, procedemos hoje como se o séc. xx, com toda a dramaticidade que o caracterizou - e «cujas estações de passagem são rotuladas de 'Munique' ou 'Pearl Harbor', 'Auschwitz' ou 'Gulag', 'Arménia ou 'Bósnia' (...)» ${ }^{6}$ - estivesse definitivamente passado.

Esta atitude de obliteração da memória ou esquecimento do passado recente é considerada pelo nosso historiador demasiado grave e plena de consequências, dado que ela fez passar a ideia ingénua segundo a qual podemos finalmente avançar - porque não onerados pelos erros passados - para uma era totalmente diferente e melhor. Uma tal vontade de esquecer, de nada aprender com as narrativas do passado, a não ser por referência aos nossos interesses muito atuais, tantas vezes díspares, acaba por desligar-nos de uma tradição comum e, como tal, da nossa própria humanidade. Mas retira-nos sobretudo a capacidade de intervenção na praxis do presente, por falta de balizas e pontos de confronto; desenraíza-nos, por fim, alienando a nossa própria capacidade de crítica e de decisão. Como nos diz Judt, este fenómeno é absolutamente novo e, diríamos nós, para além de novo, perigoso e desmobilizador da vida ética e política que é a da partilha de horizontes, a da decisão e da escolha do bem comum. A história tradicional, lembra-nos ainda Judt, neste sentido, ensinada a gerações de crianças e de estudantes universitários, dava justamente um sentido ao presente por referência ao passado. Ora, (...) na nossa época, todo esse processo se inverteu. «Agora o passado não tem acordada uma forma de narrativa própria. Só adquire significado por referência aos nossos interesses atuais tantas vezes díspares»?

De todas as ilusões contemporâneas deste século xxi, aquela que Judt considera a mais perigosa é justamente a que se gerou já no final do séc. xx e nos primeiros anos do novo século. De acordo com ela vivemos hoje uma época sem precedentes. O que tem querido dizer que consideramos que o passado já nada tem a ensinar-nos, «exceto quando se trata de o pilhar em busca de precedentes convenientes» ${ }^{8}$.

Perguntemos então com o nosso historiador: como entender uma tal atitude e sobretudo como explicá-la? Da seguinte maneira: o Estado providência europeu

\footnotetext{
5 TONY JUDT, op. cit., p. 14

6 IDEM, ibidem.

7 IDEM, ibidem, p. 16.

8 IDEM, ibidem, p. 30
} 
que nasceu no séc. xx de um consenso transpartidário e foi implementado, na maioria dos casos por liberais e conservadores que tinham entrado na vida pública muito antes de 1914, construiu-se fundamentalmente após a guerra como uma barreira contra o regresso dos sofrimentos e horrores do passado. Neste sentido os Estados providência foram Estados profiláticos ${ }^{9}$, justamente concebidos, de uma forma muito consciente, para responder ao anseio generalizado de segurança e de estabilidade e deram resultados muito para além das expetativas. Com efeito, com eles asseguraram-se os serviços públicos médicos universais, as pensões de velhice, os subsídios de desemprego e de doença ${ }^{10}$, a educação garantida, os transportes públicos subsidiados e outros pré-requisitos de uma ordem civil estável, aquela que hoje começamos a ver claramente ameaçada. O que correu mal então nesta passagem? Diz-nos Tony Judt: «O paradoxo, claro é que o próprio êxito da economia mista dos Estados providência, ao proporcionar a estabilidade social e a desmobilização ideológica, que tornaram possível a prosperidade do último meio século, levou uma geração política, mais jovem, a tomar por garantida essa mesma estabilidade e imobilidade ideológica e a exigir a eliminação do «estorvo» do Estado, tributador, regulador e geralmente interferente. Se o argumento económico para isso é tão seguro como agora parece (...) é discutível. Mas o que surpreende é até que ponto perdemos a capacidade de conceber a política pública para lá de um economicismo interpretado com tacanhez. Esquecemo-nos de como pensar politicamente ${ }^{11}$.

Vivemos hoje, com efeito, numa era a-política, isto é, somos céticos ou mesmo profundamente desconfiados relativamente a objetivos políticos envolventes. Assim, "as grandes narrativas da Nação, História, Progresso, que caracterizaram as famílias políticas do séc. $x x$, parecem irrevogavelmente desacreditadas $\aleph^{12}$. Não existem mais escolhas políticas significativas a fazer, quando a política económica é tudo o que realmente conta e quando esta mesma política (económica) é agora fundamentalmente determinada por atores não políticos, bancos centrais, agências internacionais ou empresas transnacionais.

\footnotetext{
9 IDEM, ibidem, p. 22

10 IDEM, ibidem, p. 21-22.

11 IDEM, ibidem, p. 22.

12 IDEM, ibidem, p. 23.
} 
Estamos pois predispostos, nos dias de hoje, a olhar para o séc. xx como uma era de extremos políticos, de erros trágicos e de escolhas irracionais, como uma era de ilusão da qual felizmente nos libertámos. Mas não estaremos igualmente iludidos? "Será que as circunstâncias do séc. xx foram realmente tão invulgares, únicas e irrepetíveis, será que podemos ter a certeza de que nunca mais voltará aquilo que impeliu homens e mulheres para as grandes narrativas da revolução e da renovação? Será que os planaltos ensolarados da paz, da democracia e do mercado livre chegaram mesmo para ficar?»13 Não será justamente a crise que hoje nos assola um sintoma que nos faz dar plena razão a Judt? «O medo está a ressurgir como ingrediente ativo na vida política das democracias ocidentais. Medo do terrorismo, decerto; mas também, e talvez de forma mais insidiosa medo da mudança, medo da crise, medo da perda de emprego com toda a sua dimensão de sofrimento.

Como sair então desta situação? Eis a questão a que Judt só responde de forma indireta dizendo: "Julgamos que aprendemos o suficiente do passado para saber que muitas das velhas respostas não resultam, e isso pode até ser verdade. Mas o que o passado pode realmente ajudar-nos a compreender é a complexidade perene das perguntas» ${ }^{14}$.

Esta compreensão foi, podemos dizê-lo, a grande mensagem que os filósofos sempre aprenderam e por isso a Filosofia, sempre nascida do espanto ou crise de um sentido, que já não satisfaz e deve ser procurado a um outro nível, sempre voltou à pergunta do passado, a partir das respostas do presente. Com efeito, neste seu perguntar ela não retoma exatamente a pergunta do passado, mas reinterpreta, a partir dos conceitos do presente, o seu horizonte inesgotável de referência. Por isso, a Filosofia, que não quer ser pura sistemática nem se contenta com o mundo da pura transparência, nasce como uma resposta nunca totalizante à crise dos quadros do passado. Nunca o esqueçamos: a filosofia nasceu da praxis e da organização dos assuntos da cidade-estado no mundo grego. Muito aprendemos, neste sentido, com os gregos, nomeadamente com Aristóteles, filósofo grego que, hoje, em tempos de crise ética revela toda a sua atualidade. A ele devemos, de facto, a constituição de uma filosofia prática,

13 IDEM, ibidem, p. 27.

14 IDEM, ibidem, p. 33. 
terreno por excelência da Política, que exerceu no mundo europeu a sua influência até ao séc. xix e que no século xx foi substituída pela chamada "Ciência Política ou Politologia "15. E, note-se, por muito estranho que pareça a um espírito fascinado pelo encanto da teoria pura, pelo da crítica literária ou crítica de arte etc., a ele devemos ainda a ideia de que foi no reino concreto, áspero e duro do obstáculo e do valor, do interesse e do empenhamento que as expressões crise e crítica ganharam sentido.

Crise e crítica, refere a este respeito M. Baptista Pereira, têm origem no verbo grego krinô que significa separar, escolher, julgar e decidir ${ }^{16}$. O uso grego das palavras krinô e krisis cedo invadiu a linguagem jurídica e, por isso krisis, além de significar separação e disputa, designou também a decisão no sentido de uma sentença, de um juízo definitivo. Além de que, como nos mostra ainda o Saudoso Professor, a palavra krisis no sentido de decisão judicial ficou vinculada à ideia de estabelecimento da ordem e foi neste sentido que Aristóteles a usou na Política. Com efeito, a organização política e jurídica da comunidade dependia da justa decisão do juiz, acatada pelo cidadão. E lembra-nos ainda Miguel Baptista Pereira: ao sentido jurídico do termo crise como decisão, juntou-se no mundo clássico o seu uso pela medicina sendo a crise da doença e o juízo médico "conceitos coordenados entre si, pois, é a partir da 'mudança súbita da doença', sobretudo para o melhor e dos correspondentes sintomas, que o médico pode diagnosticar o futuro do doente ${ }^{17}$. Já Platão no Fedro se serve da Medicina para defender que não é a soma dos conhecimentos relativos à ciência médica que chega para definir o que é um bom médico, pois é preciso fundamentalmente que este saiba como aplicá-los.

Ora, é esta aplicação ou individualização que constitui a experiência de crise, no sentido de juízo e decisão imediatos sobre o estado concreto do doente. É da relação à experiência viva, da relação à vida concreta e ativa do homem, que o sentido de crise retira a sua real dimensão de decisão e aplicação. Era também neste sentido que, para a filosofia prática de Aristóteles, (urdida em volta do bem prático do homem), toda a construção filosófica sobre esta temática, apenas faz sentido na decisão ou crise da vida concreta. Assim, se a filosofia prática

\footnotetext{
15 M. BAPTISTA PEREIRA, op. cit., p. 116.

16 IDEM, ibidem, p. 102.

17 IDEM, ibidem, p. 111.
} 
pressupunha "conceitos normativos transmitidos por educação e configuradores da ordem social, não era menos certo que tais ideias reguladoras não eram imutáveis nem tão-pouco gozavam de imunidade crítica. Sofriam, pelo contrário, as transmutações que lhes eram impostas pela experiência solidária concreta, sempre 'outra' da deliberação em contexto. Por isso para Aristóteles, as virtudes morais pressupunham a comunidade das representações do bom, do mau, do justo e do injusto, representações que criavam a comunidade doméstica e política e se abriam ainda e sobretudo a uma forma de crise ou escolha ética. Escolha esta que, por sua vez, era definida nestes termos: "preferir uma coisa a outra a partir do fundamento da reflexão» ${ }^{18}$.

E, ao contrário da atividade técnica, Aristóteles mostrava-nos ainda que a crise ou decisão prática não tinha qualquer fim exterior a ela mesma e, por isso, não precisava de subordinar meios a fins nem necessitava da correspondente lógica subsuntiva, que eliminaria toda a crise. Neste sentido, para o filósofo grego, e cito ainda o texto "Crise e crítica" de Miguel Baptista Pereira: "As coleções de leis e de constituições só serão úteis àqueles que, em virtude da sua experiência têm possibilidades de as julgar, isto é, de as criticar retamente. As opiniões dos próprios sábios valem apenas condicionalmente, porque 'a verdade nas coisas práticas é julgada a partir das relações de facto da vida'. Embora a Política seja uma atividade e uma ciência de domínio, o seu fim subordina-se à praxis: formar os cidadãos, tornando-os bons e capazes de bem agir (...). A política põe o problema do novo e do diferente, perante as leis tradicionais e, por isso, Aristóteles pergunta se é politicamente prejudicial ou útil 'mudar' as leis tradicionais, quando algo de melhor se oferece» ${ }^{19}$.

Retenhamos então: surgida da participação do homem no mundo concreto, a crise é para a consciência humana, que julga e decide, a revelação de uma realidade nova e diferente porque temporal. Exige tradição, escolha e aplicação. A eliminação científica da crise coincidiria com o fim da história. Foi este o objetivo de A. Comte, para quem o estádio positivo do saber realizaria a consumação dos tempos pois não haveria qualquer alternativa ao progresso indefinido da ciência e da técnica e portanto nenhuma possibilidade crise $^{20}$. Sabemos no,

\footnotetext{
18 IDEM, ibidem, p. 120.

19 IDEM, ibidem, p. 123.

20 IDEM, ibidem, p. 139.
} 
entanto, pelo menos quem pratica a filosofia hermenêutica que o que vale a pena gera a crise histórica da razão, que exige reflexão e deliberação. Desta experiência vive hoje a hermenêutica filosófica que sabe que a praxis simbólica do homem não se deixa pré-determinar, nem escapa à crise. Lembramos de novo o contributo de M.Baptista Pereira e suas palavras sábias: "O topos de crise e crítica é a hermenêutica jamais definitiva da praxis simbólica» ${ }^{21}$.

\section{II}

É, de facto, da trama simbólica complexa da praxis humana que precede e funda o trabalho teórico, que nasce a problemática hermenêutica, quer na sua dimensão pré- filosófica de disciplina auxiliar da Teologia da Filologia e da Jurisprudência, quer na sua dimensão filosófica, ocorrida com o advento da consciência histórica no séc. XIx. A hermenêutica desenvolvida como ars interpretandi até ao Romantismo foi a forma de formação do homem culto e crente, greco-romano, medieval, renascentista e moderno e não esqueçamos, no período do Renascimento afirma-se como o grande movimento de crise de tradição, nomeadamente, com o fenómeno da Reforma protestante. Por outras palavras, a diferença histórica dos tempos modernos, obrigou com Lutero, a uma nova interpretação/aplicação do sentido da Escritura, a uma decisão em prol da scriptura sola, decisão esta que deu forma e figura ao futuro da interpretação bíblica. A crise do sentido dogmático da tradição não pôs aqui de modo algum, em causa a validade do texto transmitido, mas pelo contrário propôs uma nova aplicação. Um conflito de interpretações impõe-se então como resultado da crise que, detetando a dimensão simbólica e excessiva do transmitido, lutou contra a sua fixação dogmática e a-temporal.

O problema da hermenêutica sempre foi o da deliberação, situada entre tradição e crise, isto é, o da aplicação do transmitido a novas situações. Assim um filósofo como Gadamer pôde, na sua obra Verdade e método ${ }^{22}$, caracterizar a crise ou aplicação como o núcleo fundamental da Hermenêutica filosófica. Ela

\footnotetext{
21 IDEM, ibidem, p. 138

22 H. G. GADAMER, Gesammelte Werke, Hermeneutik I.Wabrheit und Methode 1, Tubingen Möhr, 1968
} 
nasce da transmissão do sentido, que caracteriza as comunidades humanas, e sobretudo do efeito histórico desta e o seu eixo decisivo não é a aplicação cega dos conteúdos transmitidos às virtualidades do presente. É, pelo contrário, como sempre o mostrou a própria hermenêutica jurídica o ato de traduzir e aplicar a lei à situação concreta que pede justiça. Da compreensão hermenêutica faz pois parte um acontecer que provoca crise, escolha e compromisso e não um simples reconstruir. Compreender é fazer com que possamos entender o que a mediação dos símbolos e narrativas do passado nos transmite, em termos de organização ética e social dos assuntos humanos. Mas é também perceber que é necessário desistir da ideia de que existe uma compreensão única, plena e total.

Só se interpreta, de facto, quando não existe uma compreensão total e imediata, um acordo claro e estabelecido, de uma vez por todas, e quando uma tarefa prática ou deliberativa está no horizonte. É neste sentido que Gadamer considera que a hermenêutica jurídica recorda por si própria de forma exemplar, o verdadeiro procedimento de uma hermenêutica ${ }^{23}$. Nela temos, de facto, o modelo de relação de passado e de presente de que estávamos à procura. Quando o juiz tenta aplicar a lei transmitida às necessidades do presente, tem claramente a intenção de resolver uma tarefa prática. O que de modo nenhum quer dizer que a sua interpretação da lei seja arbitrária. Também no seu caso, compreender e interpretar significa conhecer e reconhecer um sentido vigente. O juiz tentará responder 'à ideia jurídica' da lei mediando-a com o presente. Esta é evidentemente uma mediação jurídica. O que ele tenta reconhecer é o significado jurídico da lei e não o significado histórico da sua promulgação ou uns casos específicos sua aplicação (....) "A tarefa da interpretação consiste em concretizar a lei em cada caso, isto é, consiste na sua aplicação» ${ }^{24}$.

A Hermenêutica vive de tradição e crise e sabe que o ser humano, porque é finito, parte sempre de pressupostos, logo de um mundo herdado e transmitido. Chegamos, com efeito, sempre demasiadamente tarde para fundamentar pelos nossos próprios meios a simbólica narrativa que guia o nosso agir; estamos já sempre misturados em histórias, valores, leis, que orientam a nossa ação no mundo. É esta a verdadeira condição do nosso agir prático de ordem ética e

23 IDEM, ibidem, pp. 330 ss.

24 IDEM, ibidem, p. 335. 
moral: herdamos quadros que nos chegam a partir da tradição. Mas se não queremos ser macacos repetidores, esta herança tem que ser recriada na situação que nos concerne. Compreender ou agir não é aqui dominar uma situação, a partir de categorias prévias, mas saber-se afetado pelo assunto em questão e atualizá-lo em determinada situação, deliberando sobre ele. A aplicação é sempre uma exigência ética, uma explicitação interessada e não neutra do assunto veiculado pelo texto; sublinha nele determinados contornos, é uma tarefa eminentemente ética e prática.

Partimos sempre de figurações simbólicas do passado, de costumes e tradições que devem, por sua vez, ser ampliadas e discutidas, em cada situação concreta da ação, quer isto dizer, assumidas de modo novo e diferente. Sem a crise hermenêutica séria, que convida à deliberação, vivemos na repetição e somos transformados em autómatos. Fugimos à exigência prática da crise, no sentido hermenêutico de decisão, aplicação, responsabilização... e, no entanto, uma outra crise nos apanha.... a crise contemporânea, dita económica que nos parece definitiva e não provisória.

\section{III}

Recorro, para compreender este novo sentido de crise, ao contributo de P. Ricoeur, no artigo «Será a crise um fenómeno especificamente moderno?». Neste texto, que reproduz uma conferência pronunciada pelo filósofo em Neuchâtel em 1986, a questão central em volta da qual o nosso filósofo faz a sua hermenêutica da crise é a seguinte: viveremos nos dias de hoje uma crise, sem precedentes, uma crise definitiva e pela primeira vez nada provisória? Questão que se desdobra nas seguintes: O que será que esta crise tem a ver com a nossa modernidade? "Será a modernidade uma causa de crise generalizada? Será que a modernidade, isto é, o nosso presente, exclui toda a possibilidade de voltar atrás? Ou ainda será que assistimos a uma crise da própria modernidade?

Para responder a esta questão, tão vasta, o autor começa por nos dizer que a ideia que hoje temos da crise está cheia de equívocos, logo que é preciso esclarecê-los. Com efeito, os conceitos habituais de crise são regionais: a crise de choro, de valores etc., que parecem nada ter a ver com este sentido global 
que hoje se insinua pela primeira vez e que tem que ver com as próprias representações que a nossa sociedade faz de si própria. Por meio deste tipo de representações, que a ideia generalizada de crise, de crise económica e de mundialização da crise suscitam, Ricoeur procura na condição humana a raiz da crise interpretando-a a partir da temporalidade da experiência humana na dialética, que é a sua, e que foi evidenciada por Koselleck, de espaço de experiência e horizonte de expectativa.

Mas o filósofo começa propositadamente a sua análise pelos conceitos habituais, regionais e produtivos de crise que conhecemos. Coloca em primeiro lugar, a análise mais vulgar, a crise em sentido médico: esta implica agravamento, sofrimento, exige diagnóstico, decisão e tem resolução; em segundo lugar, trata a crise no contexto do desenvolvimento psicofisiológico do ser humano, cujo exemplo paradigmático, por excelência, é a adolescência, caracterizada por E. Eriksson. Aqui também a crise não tem o sentido ameaçador de catástrofe, mas o de uma viragem, de «um período crucial de vulnerabilidade acrescida e de potencialidade acentuada e, por conseguinte, a fonte ontogenética de força criadora mas também de desequilíbrio ${ }^{25}$.

Em terceiro lugar, Ricoeur analisa um sentido cosmopolítico de crise, que também não tem a dimensão de tragédia, a crise no sentido que Kant deu a este termo, nos seus escritos de filosofia da história: uma passagem da menoridade à maioridade. "Ousa servir-te das Luzes da tua própria razão. Acorda em ti as Luzes do espírito". A crise não é aqui de modo algum permanente; é acompanhada pelo papel profundamente crítico do educador público que não cuida já de um desenvolvimento orgânico imanente, mas efetua uma crítica da situação de domínio, responsável pelo atraso da humanidade. Quer dizer, também aqui, no século da crítica, a crise não é ameaça de catástrofe, dado o horizonte otimista do progresso da altura e o papel de educador do género humano atribuído à filosofia. Vem em seguida o modelo epistemológico de crise de paradigma, tal como ele foi cunhado por Kuhn ${ }^{26}$ na sua conhecida obra sobre as revoluções científicas. Também aqui pelo facto de experiências ou conhecimentos em número suficiente não se deixarem integrar no anterior paradigma do conhecimento, a crise não tem o sentido de desastre, pois é transitória e obriga a mudar de paradigma.

\footnotetext{
25 P. RICOEUR, op. cit., p. 3.

26 IDEM, ibidem, pp. 5-6
} 
Surge por fim a dimensão económica propriamente dita do fenómeno que nos assola. Claramente, Ricoeur não quer sobrevalorizá-la. É que se, como nos diz, ela comunica já com os fenómenos de maior amplitude, que obrigam o analista a levar a reflexão para um plano mais vasto, o do fenómeno social global, importa "manter o uso do plural e falar de crises, de forma a levar em conta 'a diversidade, a sucessão cronológica das crises determinadas, discerníveis e que apresentam cada uma traços que as distinguem das outras'».

Retenhamos então: Ricoeur começa deliberadamente por uma abordagem analítica e fragmentária do fenómeno da crise, para nos mostrar que esta não tem necessariamente um carácter ameaçador, faz parte da vida humana, revela como a existência está exposta ao sofrimento, que sempre marca a mudança de um estado de equilíbrio anterior logo, que exige decisão, escolha e solução. Ricoeur sublinha ainda que estas análises fragmentárias lhe permitem perceber que o traço empírico mais visível da crise é a rutura de um antigo equilíbrio seguida de sofrimento, de queda e de solução. Assim, no âmbito da crise económica, tal como no médico são sempre os sofrimentos que fazem pairar uma ameaça sobre todos os outros equilíbrios, e neste âmbito económico propriamente sobre "a ideologia dominante, isto é, sobre a hierarquia de valores pela qual uma sociedade global se define» ${ }^{27}$. E aqui está pela primeira vez algo de novo quanto à crise económica: «é numa civilização como a nossa, que coloca a economia no topo da sua hierarquia de valores que a forma económica da crise é erigida em modelo de todas as crises ${ }^{28}$. É precisamente a sociedade que mais valoriza a dimensão económica da sua existência que sente a desordem económica como não sendo parcial, mas, pelo contrário total. No entanto, analisando a periodicidade das crises económicas dos séc. xix e xx, Ricoeur conclui que no sentido económico a crise sempre manteve a esperança de ser sempre transitória, isto é, acreditou-se sempre que há uma saída para a crise.

Hoje, no entanto, é a mundialização da crise que nos faz pensar (...) mais, num fenómeno novo e subjacente, a mundialização do mercado. Ora, diz o nosso filósofo, a compreensão deste fenómeno obriga a sair do horizonte limitado da análise económica e a colocar a questão da mundialização do fenómeno de

27 IDEM, ibidem, p. 6.

28 IDEM, ibidem. 
autonomia e da predominância da economia relativamente aos outros componentes, mais simbólicos da coesão social. Então o que está aqui em jogo são as próprias representações que a sociedade faz do seu funcionamento, o que nos obriga a efetuar uma hermenêutica das suas ideias e dos seus valores. Quer dizer, é a sociedade contemporânea, filha da modernidade iluminista que, mundializada hoje pelo primado da razão instrumental, parece estar em crise, revelando a crise de um mundo global, o europeu, em que tudo é reduzido a mercadoria. Mundializada (estendendo-se geograficamente), a crise põe ainda em jogo, para além dos fatores ideológicos já revelados, uma dimensão propriamente política que por toda a Europa revela: a) a perda de confiança das opiniões públicas nos seus dirigentes; b) a contradição entre a dimensão nacional dos Estados e a dimensão internacional da crise ${ }^{29}$.

Quer dizer então que os fenómenos de unificação, de extensão, de emancipação do mercado que, como nos diz o filósofo "podiam de igual modo ser tidos pela causa ou efeito de outras alterações, em particular ao nível das mentalidades »30, põem pela sua pertença à configuração de ideias e valores característica da sociedade moderna, claramente em jogo a nossa modernidade. «É a sociedade enquanto todo que, na época moderna, se define, pela primeira vez, pela autonomia do mercado dilatado às dimensões do mundo ${ }^{31}$. Surge, então, pela primeira vez, pensa Ricoeur a necessidade de passar de um modelo fragmentário a um englobante que possa coordenar estes esboços imperfeitos de generalização da crise e que permita uma abordagem holística desta.

Para isso, o filósofo francês recorre às filosofias existenciais de índole personalista, que muito o influenciaram, nomeadamente a P. Landsberg e a E. Mounier. Na esteira de Max Scheler, estes filósofos dão, na sua visão do homem, um lugar decisivo ao conflito, à rutura ao risco e, neste sentido à noção de crise. Por outras palavras, para os filósofos referidos a pessoa é representada mediante traços dramáticos, sempre "dilacerada entre as forças da vida que a lançam em direção a um êxtase negro e forças espirituais que a impelem em direção a um êxtase superior ${ }^{32}$. A crise reside no próprio fenómeno temporal do processo de personalização,

\footnotetext{
29 IDEM, ibidem, p. 9.

30 IDEM, ibidem, p. 11.

31 IDEM, ibidem, p. 12.

32 IDEM, ibidem, p. 32.
} 
que é sempre uma operação de hierarquização, a descoberta de uma nova ordem, dado que a própria nunca é a natural. Ora, «esta atividade de hierarquizar, a que o homem está condenado, não acontece sem um juízo de preferência, uma crisis que decide no seio da confusão das pulsões” ${ }^{33}$. Nesta linha (de Mounier e Landsberg), a grande perturbação reside na experiência de não saber mais qual é o meu lugar no universo, no facto de eu deixar de saber qual a escala de valores estável que pode guiar as minhas preferências.

Neste caso, só mesmo o compromisso pode intimar-me a uma hierarquia do preferível, identificando-me com uma causa que me ultrapasse. A crise nasce assim na encruzilhada em que o compromisso luta contra a tendência para inércia. O que quer dizer que, sob esta perspetiva, poderemos mesmo dizer que a travessia da crise caracteriza o itinerário humano no tempo e que só o compromisso prepara o futuro; o essencial da crise reside então na confrontação entre futuro e passado no processo de personalização ${ }^{34}$.

Justamente para Ricoeur, o importante desta análise reside na relação que ela permite estabelecer entre crise e temporalidade. E reencontramos de novo a mensagem de Judt, pensada agora com os meios da análise filosófica. Transposto este nexo de crise e temporalidade para o plano da nossa consciência histórica, caracterizada por R. Koselleck, na sua obra Vergangene Zukunft (citada por Ricoeur), pela dialética dos dois grandes tanscendentais da temporalidade humana, o espaço de experiência e o horizonte de expectativa, podemos dizer então com Ricoeur que, quando o espaço de experiência se estreita pela recusa/ esquecimento do passado ou da transmissão, o horizonte de expectativa tende a estender-se para um futuro cada vez mais vago e indistinto. Surge então um futuro "povoado de utopias ou ucronias sem influência sobre o curso efetivo da história» e "nesse instante a tensão entre o horizonte de expectativa e o espaço de experiência transforma-se em rutura, cisma ${ }^{35}$. É esta a nossa situação. Será ela sem remédio?

Perguntando, por fim, se poderemos usar este critério de crise global, que tem a vantagem de envolver em si os critérios regionais anteriores à nossa época, para pensar o presente, Ricoeur responde: Mas como podemos avaliá-lo, se

\footnotetext{
33 IDEM, ibidem, p. 12.

34 IDEM, ibidem, p. 13.

35 IDEM, ibidem, p. 14.
} 
estamos dentro dele? E explica: existem, no entanto, muitas interpretações da modernidade que a caracterizam como uma época de individualismo, de que o liberalismo económico é apenas uma variante. Mas também como uma época em que apesar do individualismo, como ideologia dominante, ela engloba ainda o seu contrário, os valores da sociedade tradicional.

Não estará então a verdadeira crise na hesitação da nossa sociedade entre modelo social tradicional, entre o modelo moderno e o pós-moderno? Ricoeur entende aqui pós-modernidade, no sentido que lhe dá Louis Dumont quando considera que a sociedade moderna, de alavanca da crise se tornou, por sua vez, o lugar da crise; o que explica o recurso à ideia de pós- modernidade. Não radicará a crise, como o pensa a escola de Frankfurt, nas promessas não mantidas do Iluminismo? Na conversão da sua racionalidade em razão instrumental? Não será o humanismo moribundo e o seu desencantamento do mundo, a retirada dos deuses e dos valores, uma razão da crise?

De agente da crise de um mundo marcadamente religioso e metafísico, o humanismo antropocêntrico tornou-se hoje o lugar da crise e, finalmente a vítima da crise por decomposição interna. No entanto, é curioso: hoje vários são os sectores da sociedade, a clamar por um novo humanismo (veja-se o caso da Bioética).

Ricoeur conclui então a sua apreciação da época contemporânea deste modo: nas diversas interpretações da crise contemporânea, anunciadas ou por L. Dumont, ou por Nietzsche e Heidegger, ou mesmo pela Escola de Frankfurt "O que me parece comum (...) é a ideia de sobreposição de duas crises: a da sociedade tradicional, sob a pressão da sociedade moderna, a da própria sociedade moderna, enquanto aparece como um produto abortado da sociedade tradicional» ${ }^{36}$. Dito isto, a minha dúvida inicial, respeitante à possibilidade de proceder a uma avaliação global da época presente, regressa com novos argumentos. A época atual, diz-nos, não se deixa definir por meio de uma ideologia única. As definições rivais da modernidade, a querela entre modernidade e pósmodernidade testemunham o carácter equívoco do tempo presente. Assim para o filósofo o que melhor parece caracterizar o tempo presente, como tempo de crise, é:

36 IDEM, ibidem, p. 17 
a) a ausência de consenso numa sociedade dividida entre tradição e pós-modernidade

b) o recuo geral das convicções e da capacidade de compromisso dos humanos. É ainda o afastamento do sagrado, seja ele entendido no sentido vertical, seja no horizontal (político). Como sair então da crise?

Para responder à pergunta com que começou o seu texto, «será a crise de hoje, pela primeira vez interminável», ao contrário das do passado que, como nos mostravam os modelos regionais, eram transitórias? Ricoeur afirma que tem esperança que não, porque apesar da ausência de consenso e de convicções fortes na nossa sociedade pluralista, abre-se hoje uma oportunidade inédita à reinterpretação das heranças do passado. Muito particularmente à reinterpretação do cristianismo. Só a hermenêutica, como lugar de memória e crise, no sentido de compromisso e aplicação, poderá pois salvar-nos da inércia em que caímos. A hermenêutica, lembra-nos Gadamer, o seu grande teórico já referido, cultiva um modelo de formação, de senso comum, de capacidade de juízo e de gosto que não se adquirem por meio de uma educação reduzida a instrução, mas pelo exercício hermenêutico do saber ouvir a proposta de sentido transmitida pelo outro, que fala a partir da tradição, isto é, a partir do diálogo e do aprender a não ter sempre razão.

Neste sentido, creio ser pertinente acabar todo este conjunto de reflexões por meio da referência a mais um texto, agora de H. Arendt sobre "A crise na educação» ${ }^{37}$. Este escrito teve como alvo principal a crise provocada pelo modelo americano de educação de massas, dos anos sessenta, modelo que, todos sabemos, governa hoje a Europa. Para a filósofa, que considera que uma crise é sempre a ocasião de um crescimento e de esperança, desde que haja ânimo e condições para a enfrentar, o grande problema das novas pedagogias [americanas] que, não esqueçamos, invadiram o mundo, é terem afastado completamente o papel formador da tradição. Tal afastamento bloqueou, segundo Arendt, a capacidade humana de perceber e ajuizar a crise. Assim o que mantém crise é, na opinião da filósofa, a perda das tradições e a anulação contemporânea de toda a autoridade.

37 H.ARENDT, op. cit., pp. 183-206. 
Expliquemo-nos melhor: para Arendt tal modelo de educação tem os seus fundamentos no pragmatismo; caracteriza-se por substituir as antigas teorias da aprendizagem, baseadas na tradição como apresentação do mundo àqueles que são mais novos, por teorias de um saber fazer que, aliado à racionalização técnica do mundo, se conjuga muito bem com a ideia segundo a qual um professor pode ensinar toda e qualquer coisa. Fenómeno este que desobriga, por sua vez, o docente de possuir conhecimentos teoricamente sólidos. "O professor - assim nos é explicado - é aquele que é capaz de ensinar qualquer coisa. A formação que recebe é em ensino e não no domínio de um assunto particular (...). Porque o professor não tem necessidade de conhecer a sua própria disciplina, acontece frequentemente que ele sabe pouco mais do que os seus alunos. O que daqui decorre é que, não somente os alunos são abandonados aos seus próprios meios, como ao professor é retirada a fonte mais legítima da sua autoridade enquanto professor ${ }^{38}$.

Assim se impôs no âmbito da educação a ideia de que não se pode compreender senão aquilo que qualquer um se faz por si próprio, o que leva à substituição do aprender pelo primado do fazer. «Considera-se pouco importante que o professor domine a sua disciplina porque se pretende compelir o professor ao exercício de uma constante aprendizagem para que, como se diz não transmita um 'saber morto', mas ao contrário, demonstre constantemente como se adquire esse saber. A intenção confessada não é a de ensinar um saber mas a de inculcar um saber fazer. O resultado é uma espécie de transformação das instituições de ensino geral em institutos profissionais $^{39}$.

Nesta conceção, a habilidade supera o conhecimento e a brincadeira, como nos diz Arendt, pode substituir o trabalho sério. Ora, o que de mais grave acontece é que tal modelo de educação não dá aos mais novos a possibilidade do novo. Com efeito, sem a tradição e as balizas da autoridade, em educação, as margens não têm qualquer oportunidade para surgir, logo não há capacidade para perceber o novo. Sem a apresentação que a tradição faz do mundo, aos mais novos, estes nunca terão a possibilidade de estar atentos ao novo. Só a conservação, diz-nos Arendt e também Gadamer o defende, possibilita que o novo

38 IDEM, ibidem, p. 192.

39 IDEM, ibidem, p. 193. 
possa aparecer como crise, diferença. Então o que uma verdadeira educação deve conservar é, antes de mais, a possibilidade do novo vir a ser; por outras palavras: o professor deve ter a capacidade de narrar o passado, possibilitando simultaneamente que a imaginação dos educandos o interprete. Com efeito, não há outra forma de apresentação do mundo empírico do ser humano, nas suas várias nuances, sem a tradição.

E Arendt pergunta: como manter hoje esse mínimo de conservação sem o qual a educação não é possível? De novo respondemos com a Hermenêutica que, desde a sua fase pré-filosófica, foi para o mundo greco-romano, medieval, renascentista e moderno o lugar de uma educação que sempre se apoiou na tradição, na ordenação poética e narrativa das peripécias da condição humana e no efeito configurador da sua interpretação. 


\section{BIBLIOGRAFIA}

ARENDT, Hannah, "A crise da educação", in Entre o Passado e o Futuro. Oito exercícios sobre o pensamento politico, Lisboa, Relógio de Água, 2006, pp. 183-206.

GADAMER, H.G., Gesammelte Werke, Hermeneutik I.Wahrheit und Methode 1, Tubingen Möhr, 1968.

JUDT, Tony, O Século xx Esquecido. Lugares e memórias, Lisboa, ed. 70, 2010.

PEREIRA, Miguel Baptista, "Crise e crítica», in Vértice, (1983) n XLIII, pp. 100-142.

RICOEUR, Paul, "La crise: un phénomène spécifiquement moderne?, in Revue de théologie et de philosophie, 120 (1988) pp. 1-19. 
Alexandre Franco de Sá

FLUC - LIF

\section{Da Crise da República À República da CRise}

Em geral, o conceito de crise alude a um espaço de tempo diferenciado, um hiato, capaz de introduzir um instante fugaz determinante de decisão e de rutura, de mudança e de abertura a um futuro que se constitua como o advento de algo novo. É a partir desta alusão que se compreende a origem do termo crise no verbo grego krinein, traduzível por julgar, decidir, separar. Como escreve Reinhart Koselleck, aludindo a este estatuto de clarificação e abertura que a noção de crise ostenta: «Repousa na essência de uma crise que possa surgir uma decisão, mas que esta ainda não tenha surgido. E, do mesmo modo, faz parte da crise que permaneça em aberto qual a decisão que surge. A incerteza geral numa situação crítica é, portanto, perpassada pela única certeza de que - indeterminadamente quando, mas contudo determinadamente; incertamente como, mas contudo certamente - se nos depara um fim do estado crítico. A solução possível permanece incerta, mas o próprio fim, uma reviravolta das relações existentes - de um modo ameaçador e temido ou desejado com grande esperança - é certa para os homens. A crise evoca a pergunta acerca do futuro histórico» ${ }^{40}$. A crise é, portanto, um instante que se destaca no curso do tempo, um momento crítico capaz de irromper na vida humana como uma potência propiciadora de transformação da realidade e de prospeção de um futuro. E se a noção de crise aponta para um instante decisivo e aberto ao futuro, projetado como um advento efetivo, dir-se-ia que a representação de uma crise permanente não pode deixar de se constituir, antes de mais, como a alusão ao despojamento do potencial de clarificação, transformação e mudança que a própria crise encerra. É a esta

40 Reinhart Koselleck, Kritik und Krise, Frankfurt, Suhrkamp, 1997, p. 105. 
subtração de um futuro diferenciado do presente, aberto pelo tempo crítico de uma crise, que a perpetuação de uma crise conduz. E é este, em larga medida, o estado da vida cívica portuguesa. Um tal estado corresponde, em geral, a uma crise cujo arrastamento num futuro indefinido traz consigo um puro e simples prolongamento do presente e, nesta medida, uma amputação do futuro através da subtração de qualquer capacidade de mudança.

A subtração do futuro manifesta-se em Portugal, antes de mais, numa vida social e política particularmente despojada de capacidade de transformação. Esta hostilidade à mudança é um fenómeno facilmente percetível, se pensarmos o quanto, em Portugal, tudo se organiza no sentido da conservação de um status quo: o quanto a sociedade é ocupada por um poder mediático pobre e fechado (assente sobretudo na televisão); o quanto este poder mediático é, por sua vez, ocupado pelo "poder", representado sobretudo por partidos que mantêm com os media relações da maior intimidade; ou o quanto o próprio Estado é ocupado por estes mesmos partidos, os quais se instalam nele e tornam os seus interesses, estruturas e funcionários indiferenciados de interesses, estruturas e funcionários estatais. Configurando assim a sua "esfera pública", dir-se-ia que é de um modo só aparentemente paradoxal que a crise em Portugal não convida à mudança. Longe de instaurar uma consciencialização da necessidade da mudança, a crise crónica portuguesa tem-se caracterizado por instigar a que a vida política em Portugal se constitua como uma espécie de camada protetora isolante, como uma espécie de redoma na qual se produz o efeito estranho de um país que procura ser, de certa forma, imune à vida. Portugal, como comunidade política, alicerça-se nesta imunidade, isto é, nesta circunscrição de um mundo próprio que se subtrai à "comunidade" propriamente dita, vedando-se ao confronto, ao risco e à partilha. O filósofo napolitano Roberto Esposito propôs-se pensar toda a política moderna a partir de um movimento paradoxal no qual aquilo que é "comum" na política - em latim: o munus - se subtrai na própria vida em comum, deixando àquilo que é partilhado, à co-mmunitas da comunidade, apenas a $i$-mmunitas que a nega ${ }^{41}$. A política moderna seria, assim, constituída pelas características de uma comunidade marcada pela própria subtração da comunidade, através do aparecimento de indivíduos que partilham apenas a

41 Cf. Roberto Esposito, Communitas: origine e destino della comunità, Turim, Einaudi, 2006. 
sua ausência de partilha, o seu isolamento e a sua proteção. Partindo destas considerações, dir-se-ia que Portugal se tornou numa espécie de "república da crise", enredando-se numa crise cujo prolongamento indefinido converte o futuro em algo essencialmente indiferenciado do presente, ao reproduzir exemplarmente esta relação entre comunidade e imunidade, ou seja, criando o simulacro de uma comunidade estável a partir justamente da sua imunização face ao potencial transformador da crise. É no sentido desta imunização que a vida política portuguesa se desenvolve como uma espécie de mundo de fantasia: um mundo que abdica de qualquer interferência no "mundo real" e um mundo que procura ser imune a qualquer interferência do "mundo real" nele próprio.

Num tal mundo político de fantasia, cujos contornos quotidianos são moldados e recriados mediaticamente dia a dia, os decisores políticos cumprem o papel não de pensadores ou de executores de qualquer projeto, mas de simples administradores de um "estado de coisas" imutável e inerte. Eles tornam-se, assim, uma elite cujo mérito se não vislumbra, mas que forma uma rede de cumplicidades e favores de que muitos retiram toda a sua vida social, profissional e económica. A facilidade com que em Portugal se evocam e apresentam planos abandonados no momento seguinte, trocados por outros igualmente fugazes, ou a completa impunidade com que são tomadas decisões sem qualquer continuidade, consistência ou fundamentação, a generalização daquilo a que os portugueses chamam ironicamente a "navegação à vista", são apenas fenómenos que tornam manifesto um mundo político cujos protagonistas se comportam como se nenhum comportamento fizesse diferença, isto é, como se habitassem uma entidade intemporal e imune à realidade do próprio mundo. Articulada com tais protagonistas políticos, dir-se-ia que a vida cívica em Portugal se caracteriza por nada parecer nela consistente, por todos os acontecimentos nela se desvanecerem, tornando-se como que liquefeitos e incapazes de ganhar raízes. Foi a partir desta alienação da realidade que José Gil, com alguma razão, pôde chamar a Portugal o "país da não-inscrição"²: um país em que nada realmente acontece, ou em que tudo o que acontece é reduzido a uma superficialidade incapaz de deixar marca; um país, enfim, em que todo o espaço mediático saltita de curiosidade

42 Cf. José Gil, Portugal hoje: o medo de existir, Lisboa, Relógio d’Água, 2004, pp. 15 ss. 
em curiosidade, reproduzindo o previsível, e em cuja vida pública nada parece perdurar, arrebatar ou marcar a vida, deixando rasto ou memória.

Especificamente, a vida política portuguesa não pode deixar de aparecer, neste contexto, como o mais patente exemplo desta "não-inscrição", da exclusão de tudo quanto seja novo e da incapacidade de acolher tudo quanto esteja "fora" do já integrado e estabelecido. Como afirma José Gil: «Não há debate político: nem sequer na televisão que cria um espaço artificial, com regras predeterminadas que limitam a espontaneidade das intervenções, o acaso, e a participação desse "fora" que faz toda a riqueza da expressão pública. Nos jornais e na rádio, os debates confinam-se a trocas de opiniões e argumentos entre homens políticos, sempre de um partido, visto que no mundo da política não há lugar para independente, ou entre comentadores, pretensos "opinion makers» que dialogam constantemente entre si, em círculo fechado. Muitos dos políticos são também comentadores, fazem o discurso e o metadiscurso, o que suscita um circuito abafador e redundante: sempre as mesmas vozes e a mesma escrita nos mesmos tons, com os mesmos argumentos, com o mesmo plano de sentido, como se as ideias políticas se reduzissem a um empirismo sociológico de estratégias partidárias. Se a política é "chata» em Portugal, se os portugueses estão "fartos dos políticos», isso não se deve apenas à sua incompetência, mas também ao próprio universo do debate político em que nada de novo, de inovador, de diferente, de forte, de original e estimulante surge para abalar os espíritos» ${ }^{43}$. Partindo do diagnóstico que assim é traçado, é importante, antes de mais, perguntar pelas origens da "não-inscrição" que marca Portugal como uma "república da crise", como uma república em que o futuro é amputado e em que todo o espaço mediático, híper-visibilizando o presente, se constitui em torno da invisibilização de tudo o que se subtraia à sua estrutura de poder. Por que razão se gerou em Portugal uma crise cujo prolongamento num futuro indefinido resulta num despojamento do potencial crítico e clarificador, transformador e genésico, que reside intrinsecamente na própria crise? Por que razão a vida política se traduz, em Portugal, numa anti-política, numa crónica imunização contra qualquer tipo de transformação e mudança? A resposta a estas questões exige que, antes de mais, clarifiquemos o conceito de política de que partimos.

43 Ibid., p. 24. 


\section{A política entre "agonismo" e "mundo público"}

O conceito de política de que partimos encontra na sua base a conjugação daquilo a que poderíamos chamar duas dimensões fundamentais do fenómeno político. A primeira dimensão a que nos referimos, e que irrompe nas mais variadas reflexões sobre a política, estendendo-se desde os diálogos platónicos em torno da pólis até à abordagem por Carl Schmitt do "conceito do político", entende a política como um tipo de relação na qual a possibilidade do conflito e da discórdia - numa palavra: o "agonismo" - é algo intrínseco, essencial e irredutível. Nesta dimensão, o que importa assinalar é a impossibilidade de reduzir o mundo político a um mundo harmónico, unitário e ordenado. Como escreve Schmitt: "O mundo político é um pluriversum, não um universum» ${ }^{44}$. A partir desta dimensão, poder-se-ia dizer que a política consiste num fenómeno relacional em que não é possível não apenas eliminar a possibilidade da discórdia, mas até erradicar definitivamente a própria possibilidade de dissensões, conflitos e violências. Por outras palavras, a partir do agonismo como dimensão irredutível do político, a política deixa de poder compreender-se como um âmbito da vida humana redutível ao plano da discussão racional, do diálogo persuasivo ou da competição entre elites participantes dos mesmos pressupostos simbólicos. É neste sentido que Chantal Mouffe, no seguimento das reflexões schmittianas em torno do conceito do político, pode definir o fenómeno político a partir da uma relação conflitual ou "agonística" na qual os participantes disputam não quem tem ou não tem razão num diálogo, mas quem tem poder suficiente para circunscrever hegemonicamente as relações de poder e o modo de vida presentes numa sociedade. Como escreve Chantal Mouffe: "Para os liberais, um adversário é simplesmente um competidor. O campo da política é para eles um terreno neutro no qual diferentes grupos competem para ocupar as posições de poder; o seu objetivo é meramente desalojar os outros para ocupar o seu lugar. Eles não põem em questão a hegemonia dominante e não há uma tentativa de transformar profundamente as relações de poder. É uma mera competição entre elites. Aquilo que está em jogo na luta agonística, pelo contrário, é a própria configuração das relações de poder em torno das quais a sociedade está

44 Carl Schmitt, Der Begriff des Politischen, Berlin, Duncker \& Humblot, 1996, p. 54. 
estruturada: é uma luta entre projetos hegemónicos opostos que nunca podem ser reconciliados racionalmente ${ }^{45}$.

A segunda dimensão do fenómeno político a que nos referimos é, por outro lado, complementar da primeira. Ela consiste na ligação da política a uma vida social partilhada e, nessa medida, à constituição de um mundo comum, o qual não pode deixar de ser, ao mesmo tempo que essencialmente plural, marcado por uma unidade e estabilidade fundamentais, isto é, marcado por uma permanência e por uma tradição subjacentes a essa mesma pluralidade. Foi sobretudo Hannah Arendt quem, no século xx, a partir de uma tentativa de retomar o sentido clássico da política, a encontrou sediada num mundo estável e tradicional que perdurasse ao longo de gerações. Esta segunda dimensão da política não pode deixar de ser acentuada, na medida em que é também ela que se torna mais frequentemente esquecida. Ela chama a atenção para o facto de que a política, longe de consistir apenas em conflitos de poder ou em disputas em torno de uma hegemonia, encontra a sua base na partilha de um mundo público duradouro por homens que se relacionam através dele. Dir-se-ia então que, se o agonismo constitui o modo como a política se fenomenaliza, sendo, nessa medida, uma condição de possibilidade do próprio fenómeno político enquanto tal, a estabilidade e a durabilidade do mundo público constituem a sede em que o agonismo político não pode deixar de repousar. Tal quer dizer que a própria política nasce da convergência destas duas dimensões: o agonismo e a partilha de um mundo público. A eliminação de uma delas, e a consequente absolutização da outra, não pode deixar de resultar numa eliminação da política e numa consequente degradação da vida cívica. Dissociar a política da existência de um mundo estável que percorre gerações, perder os laços providenciados pela memória e por uma tradição partilhada, significa, por um lado, reduzi-la a um agonismo sem base que dissolve a própria política. Mas dissociar a política do agonismo não pode deixar de significar, por outro lado, esvaziar o próprio mundo político da relação fundamental que o constitui irredutivelmente como sua possibilidade real. Usando uma formulação de matiz kantiano, poder-se-ia dizer que o agonismo sem um mundo público que o sustente é politicamente cego; e que um mundo público sem agonismo, um mundo público sem o conflito como possibilidade

45 Chantal Mouffe, On the Political, London \& New York, Routledge, 2005, p. 21. 
real, um mundo artificialmente confortável e despojado do confronto e da disputa, só o é na aparência e é, portanto, um mundo politicamente vazio.

\section{Portugal entre "agonismo" e "mundo público"}

Tentando encontrar a origem da especificidade da "república da crise" que atrás apresentámos, consideremos agora o percurso histórico português nos últimos cem anos à luz da breve reflexão sobre a política aqui introduzida. Comecemos pela data significativa de 1910, no momento em que uma monarquia com mais de setecentos anos caía às mãos da revolução republicana cujo centenário há pouco se comemorou. Durante todo o século xix, Portugal fora marcado por grande instabilidade política e social: as invasões napoleónicas, o protetorado inglês que se lhe seguiu, a independência do Brasil, a guerra civil entre os filhos de D. João VI, os levantamentos populares resultantes da vitória liberal nesta mesma guerra, a frustração das esperanças africanas pelo ultimatum inglês de 1891, a banca rota, as experiências de ditadura administrativa de João Franco. Com todos estes episódios, as instituições monárquicas eram em Portugal, no início do século xx, caraterizadas por uma extrema fragilidade, crescentemente fustigadas por uma propaganda republicana que, cada vez mais radicalizada, acabou por adotar o propósito de derrubar a monarquia pela violência e pela insurreição armada. É essencialmente através de uma convergência entre uma fragilização da monarquia e uma concomitante radicalização do movimento republicano que se torna possível explicar que, através de uma revolução mal planeada e mal conduzida, se tenha podido proclamar, em outubro de 1910, não apenas um novo regime político, mas algo que aparece, pela primeira vez, como uma espécie de brave new world que transformaria radicalmente toda a vida portuguesa. É de uma caracterização deste "admirável mundo novo" republicano que a nossa reflexão não pode deixar de partir. Duas manifestações, complementares entre si, podem permitir uma caraterização breve deste "novo mundo". A primeira manifestação a que nos referimos emerge na ação política do movimento político republicano, quer na fase final da Monarquia quer já durante o percurso do novo regime. Esta ação política - que, em fevereiro de 1908, conhece no assassínio do Rei D. Carlos e do Príncipe Luís Filipe o seu momento mais paradigmático - distingue-se pela 
assunção explícita pelo Partido Republicano Português, ao contrário do que caraterizara a sua tradição inicial, do princípio político de que as instituições deveriam ser derrubadas diretamente pela subversão, pelo uso da força e pela instrumentalização da violência. Uma tal doutrina iria deixar marcas profundas na vida política portuguesa do século xx. No seu livro O Poder e o Povo, apresentado como tese de doutoramento na Universidade de Oxford, Vasco Pulido Valente, explicando que "a Monarquia caiu porque deu "liberdades" a mais, como se queixava João Franco, e não porque deu "liberdades" a menos, como depois virtuosamente sustentou a historiografia "democrática”, esclarece a este propósito: "A cada instante o PRP forçava a legalidade estabelecida: ou seja, não se limitava a usar os seus direitos, mas sistemática e deliberadamente os transgredia» ${ }^{46}$. A adoção da ação subversiva, transgressora e violenta como critério de atuação política traduziu-se por isso, após a implantação da República em 1910, na crónica instabilidade do novo regime e na sua incapacidade para verdadeiramente se institucionalizar. Os governos do Partido Democrático, como se sabe, tinham de ser guardados por uma polícia política informal, a chamada "formiga branca", responsável por um clima de denúncias, prisões políticas e caos social. A reação contra tais governos fazia-se com revoltas e atos de insubordinação - como os de Pimenta de Castro em 1915 ou de Sidónio Pais em 1917 -, do mesmo modo que a reação democrática a tais experiências políticas se fazia com atos de violência: a revolta de 14 de maio de 1915 contra Pimenta de Castro, o assassínio de Sidónio Pais em 1918, ou o rapto e assassínio de António Granjo e Machado Santos, na Noite Sangrenta de 1921. Neste clima de perturbação, o Portugal republicano dava mostras de ser um espaço político em dissolução, no qual a violência se substituía crescentemente a qualquer tipo de ordem e coesão. Com o evoluir do regime, era esta dissolução que se manifestava como a caraterística última da política portuguesa, levando até os franceses da época à cunhagem do neologismo portugaliser como sinónimo de "anarquizar".

As caraterísticas do "novo mundo" político português, no começo do século xx, não se reduziram, porém, à prática política da anarquia e da violência. Para além desta, o novo regime conduziu também a uma profunda reconfiguração do espaço político simbólico. Se a República foi em Portugal, na sua prática política,

46 Vasco Pulido Valente, O Poder e o Povo, Lisboa, Aletheia, 2010, p. 79. 
um fenómeno essencialmente anarquizante, traduzido numa espécie de normalização da violência, esta mesma prática encontrou na própria transformação da política portuguesa como espaço simbólico um fundamento que a dotou de uma base ainda mais funda. Assim, sob o ponto de vista simbólico, o Estado republicano português tornou-se no protagonista de uma "luta fraturante" (para usar uma terminologia hodierna) de um Portugal contra outro, convertendo-se no instrumento do combate citadino, positivista e anti-católico contra um Portugal rural, arcaico e religioso. Como diz Pulido Valente: «O caráter democrático, nacionalista, anticlerical e igualitário da ideologia republicana exprimia fundamentalmente as frustrações e ambições da pequena burguesia de Lisboa. O PRP era o seu partido. Um partido lisboeta, não um partido português ${ }^{47}$. Dir-se-ia, então, que a política republicana em Portugal consistiu na redução da política a simples relações agónicas. Esta redução da política à dimensão de um agonismo absolutizado adquire visibilidade sobretudo na ocupação do espaço público português por símbolos de partido e de combate. No caso da bandeira nacional, depois de grande controvérsia, a opção final foi a da substituição das suas próprias cores - o azul e branco - pelas cores dos movimentos iberistas, marcadas pelo vermelho da revolução e pelo verde do combate positivista contra as trevas da metafísica e da religião. É esta mesma dimensão do combate em torno do simbólico que perpassa também pela mais importante reforma política da República: seguindo as pisadas da III República Francesa, a separação entre a Igreja e o Estado. Dir-se-ia que, sob a República, a laicidade do Estado e a secularização do espaço público não foi orientada por um princípio de tolerância, de liberdade religiosa e de despolitização da religião. Passou-se, neste domínio, precisamente o contrário: uma tal secularização foi dirigida pela redução da religião a uma dimensão agónica ou, o que aqui é o mesmo, por uma politização da própria questão religiosa. Assim, marcada por uma prática política crescentemente anarquizante, a República surgia também, em Portugal, como um espaço político em que a comunicação se reduzia ao combate ideológico e propagandístico. Como escreve Fernando Catroga: "Para os republicanos, o espaço público, ainda que ocupado de uma maneira delimitada e ordeira, constituía um excelente palco para a participação (comícios) e emissão de mensagens

47 Ibid., p. 66. 
políticas. Para isso, foi necessário secularizá-lo, e as restrições às procissões, à inserção de símbolos religiosos nos edifícios públicos, ao uso de hábitos talares na via pública, bem como o controlo político-administrativo da utilização dos sinos não tiveram outro objetivo. As praças e as ruas deviam ser espaços disponíveis para a simbólica e para o espectáculo político» ${ }^{48}$.

Esta conversão da política portuguesa em puro agonismo não podia deixar de ter como resultado uma drástica degradação, em Portugal, daquilo a que se poderia chamar o "mundo público" enquanto espaço de convivialidade. Para lá das crises políticas, é no ambiente geral de agressividade que a perda de um verdadeiro mundo público se torna mais imediatamente manifesta. De entre os inúmeros exemplos que expressam eloquentemente a crescente agressividade em que o mundo público português se pulveriza, poder-se-ia citar, apenas como exemplo sintomático, o texto de uma carta que Fernando Pessoa projetara enviar ao jornal A Capital, em 1915, a propósito de Afonso Costa: "O chefe do partido democrático não merece a consideração devida a qualquer vulgar membro da humanidade. Ele colocou-se fora das condições em que se pode ter piedade ou compaixão pelos homens. A sua ação através da sociedade portuguesa tem sido a dum ciclone, devastando, estragando, perturbando tudo, com a diferença, a favor do ciclone, que o ciclone, ao contrário de Costa, não emporcalha e enlameia. Para o responsável máximo do estado de anarquia, de desolação, e de tristeza em que jazem as almas portuguesas, para o sinistro chefe de regimentos de assassinos e de ladrões, não pode haver a compaixão que os combatentes leais merecem, que aos homens vulgares é devida “49. A agressividade de textos como este, que de nenhum modo é excecional, torna bem patente o quanto, no Portugal republicano, Portugal desaparece como res publica, dissolvendo-se como espaço simbólico de convivência política. E é diante da pulverização do mundo público português e da sua dissolução em puro agonismo que se pode compreender a crescente obsessão, então emergente em todos os movimentos políticos e literários portugueses, por uma reflexão em torno de Portugal enquanto entidade original, assim como em torno da restauração de um

48 Fernando Catroga, O Republicanismo em Portugal: da formação ao 5 de Outubro, Alfragide, Casa das Letras, 2010, 274.

49 Fernando Pessoa, Páginas de Pensamento Político - 1, 1910-1919 (org. António Quadros), Lisboa, Europa-América, 1986, p. 81. 
"mundo português" ou daquilo a que Teixeira de Pascoaes chamara uma "arte de ser português".

A ditadura militar que daria lugar ao Estado Novo, com a Constituição de 1933, pode ser compreendida, neste contexto, como uma contraposição de tipo dialético à redução da política a um puro agonismo. O chefe do governo do Estado Novo, Salazar, reconhecê-lo-á sempre implicitamente, insistindo em que aos então novos governantes caberia a responsabilidade de restabelecer o espaço público português como um espaço de convivialidade e de unidade nacionais, pacificando a sociedade e libertando-a do agonismo político que a corrompia. No entanto, se a preocupação fundamental do Estado Novo tinha consistido na eliminação da identificação republicana entre política e agonismo, e na restauração de um "mundo português" que transcendesse esse mesmo agonismo, tal contraposição dialética conduziu a um excesso contrário: a criação da ficção política de um "mundo português" despojado de todo e qualquer agonismo, um mundo de heróis e de santos em torno de cuja vocação civilizadora (e colonizadora) não haveria lugar para discórdias ou dissensões. Fenómenos como a concentração da política no governo, a despolitização da sociedade, a eliminação da discórdia e da oposição, o afastamento do debate público, a censura e a institucionalização da polícia política tornaram-se então, no Estado Novo, nas principais manifestações de uma política despolitizante, na qual a restauração de um "mundo português" deu lugar a um mundo público vazio, sem vida nem política: um mundo certamente pacífico e ordeiro, mas despojado das perturbações que o confronto e o agonismo, intrinsecamente essenciais à política, não podem deixar de encerrar. Tudo no Estado Novo girou em torno da paz e da tranquilidade desvitalizada daquilo a que Salazar chamara, não sem fina ironia, a "vida habitual". Como escrevia Salazar a propósito da Revolução de 28 de maio de 1926: "O País, longa e duramente experimentado por estéreis lutas políticas, tem gozado, como o maior dom da Revolução, esta calma que lhe permite dedicar-se mais confiadamente à sua vida. Têm-se-lhe poupado, sempre que possível, os sobressaltos, as preocupações, as amarguras, e o seu espírito não tem sido torturado com as nossas dúvidas e dificuldades " ${ }^{50}$. É em nome desta

50 António de Oliveira Salazar, "Balanço da obra governativa", Discursos e notas politicas II 1935-1937, Coimbra, Coimbra Editores, s.d., pp. 28-29. 
pacificação social despolitizante e desvitalizante que o Estado Novo orienta não só a sua prática política, mas também a sua organização simbólica. Para além de uma prática política que eliminaria do espaço público, discreta mas violentamente, o conflito e a discórdia, emerge o cultivo de uma educação marcada por uma propaganda $^{51}$ destinada à reconstrução do espaço simbólico de uma unidade nacional onde quem não fosse patriota - segundo um lema bem conhecido da época - não poderia ser considerado português.

Dir-se-ia, então, que o Estado Novo significou, enquanto contraposição dialética à Primeira República portuguesa, uma total inversão da relação entre Portugal e a política; mas uma inversão que teve, de um modo só aparentemente paradoxal, os mesmos resultados inevitáveis. Se a Primeira República consistira em Portugal numa espécie de eclipse da própria política na cegueira da violência e do agonismo, o Estado Novo consistiu nesse mesmo eclipse através do estabelecimento em Portugal, até 1974, de um mundo público vazio e desvitalizado. Por outras palavras: se a Primeira República correspondera, em Portugal, àquilo a que se poderia chamar um despojamento da política através de uma absolutização da sua dimensão agónica, o Estado Novo revelou-se como uma continuação deste mesmo despojamento, mas, desta vez, através da absolutização da estabilidade de um mundo que deveria excluir artificialmente do seu seio qualquer dissensão e dimensão conflitual. E foi esta exclusão da dimensão conflitual que acabou por ditar o destino do próprio Estado Novo, sobretudo após a conclusão da Segunda Guerra Mundial, no momento em que a preservação de um "mundo português" é tentada à custa de uma espécie de imunização face à história. Após uma penosa confrontação com a realidade, que, a partir da década de 1960, assolava o "mundo português" na África e na Índia, e quando o golpe militar de 25 de Abril de 1974 derrubou o Estado Novo, Portugal via-se perante o desafio de se confrontar com a política sem absolutizar, como sempre acontecera no século xx, qualquer uma das suas duas dimensões.

É precisamente a este desafio que até agora, na sua relação com a política, a democracia portuguesa não conseguiu adequadamente responder. Logo no ano

51 Sobre o papel da propaganda como construtora deste espaço simbólico, e da informação e formação como realidades políticas fundamentais, cf. o discurso de Salazar de 1940 em reunião da União Nacional: António de Oliveira Salazar, "Fins e necessidade da propaganda política", Discursos e notas políticas III - 1938-1943, Coimbra, Coimbra Editores, s.d., pp. 193 ss. 
e meio que se seguiu ao golpe militar de 25 de Abril, com os desenvolvimentos revolucionários que decorreram até novembro de 1975, com os saneamentos e as ocupações, as perseguições e a iminência de uma guerra civil, a Terceira República portuguesa teve na sua génese um breve regresso a um agonismo absolutizado. Numa situação histórica inteiramente distinta da que fora vivida na Primeira República, Portugal reencontrava a mesma relação anarquizante com a política: a mesma aniquilação do espaço público enquanto espaço convivial e a mesma transformação deste num puro e simples terreno de combate. E é em contraste com o momento da sua génese que se poderá dizer que, depois da sua pacificação, da integração europeia e da instalação de um cada vez mais monótono rotativismo partidário, a Terceira República se caracteriza hoje por uma crescente tendência para uma nova erradicação de qualquer dimensão de agonismo político; ou seja, consequentemente, para uma nova transformação do mundo público português num espaço oco e sem vida. É esta tendência persistente que pode explicar, em última análise, a especificidade da relação atual de Portugal com a política: importa reconhecer que, tal como durante o Estado Novo, Portugal tende hoje crescentemente a existir numa espécie de redoma despolitizada na qual a crise é despojada de qualquer efeito crítico ou transformador.

Dizer que a Terceira República se caracteriza politicamente pela eliminação do agonismo político, tal como o Estado Novo se caracterizou, não implica, como é óbvio, identificar empiricamente o modo de funcionamento dos dois regimes. Mas implica reconhecer, para lá dos contrastes estabelecidos pela historiografia e pelas memórias, que os dois regimes, no seu desenvolvimento histórico, não deixaram de produzir, apesar de tudo, o mesmo efeito despolitizante. O Estado Novo, como se disse, procurou aniquilar o agonismo político em Portugal através quer de uma prática política autoritária, assente na censura da opinião e na eliminação das oposições, quer de uma educação baseada na representação da honra e da unidade nacionais. No caso da Terceira República, este mesmo efeito de aniquilamento do agonismo político, e de transformação do espaço público num espaço vazio e sem vida, é produzido através de um outro tipo de associação: a associação entre uma educação em crescente degradação e uma prática política que converteu o Estado num aparelho burocrático, ocupado por partidos cuja função essencial tem consistido em gerir o status quo, reproduzir 
estruturas de poder e satisfazer interesses e "clientelas". O reconhecimento destas semelhanças estruturais entre a vida pública do Estado Novo e a da Terceira República, na sua tendência para a eliminação da dimensão agónica da política e para a perpetuação artificial de um status quo, não é grandemente original. Como escrevia já Eduardo Lourenço, na década de 1980, a propósito deste assunto: «Uma imprensa às ordens, uma máquina partidária bem montada bastam para estrangular no berço qualquer tentativa para alterar a sério o estatuto, no fundo confortável, com que a classe política pós-25 de Abril no seu conjunto vive a paradisíaca (para ela, pelo menos) vida política portuguesa. Também isto não deve surpreender: tal estatuto é o mesmo do Antigo Regime com um suplemento inexpugnável de boa consciência "democrática”, „52. Se o Estado Novo gerou um espaço público artificial e cristalizado, assente na ideia de uma unidade nacional protegida e imunizada diante da vida, a Terceira República portuguesa, "aburguesada" ainda por um modo de vida que já não consegue suportar, tende hoje ainda a conceber-se como um paraíso de correção política, como um espaço imunizado artificialmente contra tudo o que é estranho ou verdadeiramente novo. É, em definitivo, face aos resultados eminentes desta atitude anestesiante que Portugal precisa de encontrar na sua crise um novo significado político: a abertura da dimensão agónica que falta à política portuguesa e, com ela, a confrontação com um futuro que surja diante dele como algo novo, aberto e verdadeiramente adveniente.

52 Eduardo Lourenço, A esquerda na encruzilhada ou fora da história?, Lisboa, Gradiva, 2009, pp. 56-57. 


\section{BIBLIOGRAFIA}

CATROGA, Fernando, O Republicanismo em Portugal: da formação ao 5 de Outubro, Alfragide, Casa das Letras, 2010.

ESPOSITO, Roberto, Communitas: origine e destino della comunità, Turim, Einaudi, 2006.

GIL, José, Portugal hoje: o medo de existir, Lisboa, Relógio d'Água, 2004.

KOSELLECK, Reinhart, Kritik und Krise, Frankfurt, Suhrkamp, 1997.

LOURENÇO, Eduardo, A esquerda na encruzilhada ou fora da história?, Lisboa, Gradiva, 2009.

MOUFFE, Chantal, On the Political, London \& New York, Routledge, 2005.

PESSOA, Fernando, Páginas de Pensamento Político - 1, 1910-1919 (org. António Quadros), Lisboa, Europa-América, 1986.

SALAZAR, António de Oliveira, "Balanço da obra governativa", Discursos e notas políticas II - 1935-1937, Coimbra, Coimbra Editores, s.d.

SALAZAR, António de Oliveira, "Fins e necessidade da propaganda política", Discursos e notas políticas III - 1938-1943, Coimbra, Coimbra Editores, s.d.

SCHMITT, Carl, Der Begriff des Politischen, Berlin, Duncker \& Humblot, 1996.

VALENTE, Vasco Pulido, O Poder e o Povo, Lisboa, Aletheia, 2010. 
(Página deixada propositadamente em branco) 
Luís António Umbelino

FLUC - LIF

\section{Crise e Sentido}

\section{Intróito}

Nesta ocasião em que o Departamento de Filosofia, Comunicação e Informação se reúne em colóquio para meditar o tema da crise, vale a pena recordar as linhas iniciais do ensaio "Filosofia e Crise Atual de Sentido", com o qual o saudoso Prof. Miguel Baptista Pereira inaugurava a obra coletiva de 1986 Tradição e Crise. No seu estilo denso e provocador, afirmava: "Construir ou ensinar filosofia não é desertar do presente problemático que nos aflige (...) mas participar sem repetir na reserva de sentido do passado ou no seu potencial de futuro." ${ }^{53}$ A atualidade de tais palavras reforça-se hoje na contraluz de um tempo angustiado que reclama, mais do que nunca, a reabilitação das melhores possibilidades incumpridas do passado, o reforço das energias do presente e a projeção de umas e outras na construção de um futuro alternativo. Neste esforço coletivo, deverá a meditação filosófica desempenhar o seu papel. E este poderá ser, desde logo, o de pensar com densidade o próprio conceito de "crise", assim disponibilizando instrumentos teóricos suficientemente vigorosos para o aprofundar.

\section{Um critério existencial}

No cenário quase totalitário da contemporânea crise dita financeira e económica, mas que também já foi classificada de "ideológica", "cultural" e "ética", uma

53 Pereira, M.B., "Filosofia e Crise Actual de Sentido", in AAVV, Tradição e Crise, FLUC, Coimbra, 1986, p. 5. 
pergunta quase nunca é formulada: do que falamos exatamente quando falamos de crise? Isto é: por que razão e seguindo que critério somos levados a caracterizar determinado estado, contexto, situação, período como sendo "de crise"?

Não se trata de uma questão fácil, desde logo pelo facto de se utilizar o termo "crise" para qualificar uma grande variedade de fenómenos aparentemente diferentes. Basta assistir a um qualquer programa noticioso para escutar expressões como: "a crise em que o país está mergulhado", a "crise no médio-oriente adensa-se", "há uma crise de talentos", "continua a crise de vocações", regista-se uma "crise de resultados", "o casamento está em crise", "a crise do saber", etc. Acresce a esta variedade de usos o facto de cada um deles poder ser configurado por uma multiplicidade de modelos de referência. O filósofo francês P. Ricoeur viu-o bem e por isso começa o seu artigo "La crise, un phénomène spécifiquement moderne?" ${ }^{4}$ elencando os principais conceitos "regionais" de crise, à procura de significados básicos que, presentes nos vários modos de uso do conceito, sirvam de ancoragem à análise. Assim, analisa o modelo médico da crise, o modelo do desenvolvimento psico-fisiológico, o modelo que denomina, na esteira de Kant, de cosmopolítico, o modelo de crise fornecido pela história das ciências, ilustrado pela obra de Th. Kuhn, e finalmente o modelo da crise dita "económica", hoje representada pelos problemas decorrentes da desregulação dos mercados financeiros que se globalizam ao mesmo tempo que se tornam perigosamente autónomos em relação a qualquer controlo político democrático.

De qualquer um destes modelos é possível fazer derivar um certo grau de generalização capaz de nos oferecer algumas orientações para responder à nossa questão inicial sobre o sentido da crise. Consideremos dois exemplos de entre os apontados: é possível usar o termo crise por referência ao "modelo médico" de crise e, assim, o termo é associado a uma doença - súbita -, a um contexto patológico - anormal - revelado por sintomas precisos de sofrimento ou mal-estar, que reclamam diagnóstico e intervenção especializada. É assim que podemos estabelecer analogias do tipo: "o país está doente", "esta situação já não tem cura", etc. Mas se considerarmos o modelo científico ilustrado por Kuhn, uma situação de crise já é entendida como situação imprescindível ao avanço do

54 RICOEUR, P., "La crise, un phénomène spécifiquement moderne?", in Revue de théologie et de philosophie, 120 (1988), p. 1-19, consultado em http://www.fondsricoeur.fr/photo/crise(4).pdf 
conhecimento e à mudança de paradigmas. É assim que podemos encontrar no discurso dos mais otimistas a ideia de que "a crise mudará tudo", a convicção de que "agora temos de pensar de outra forma", ou a crença em que "a situação nunca mais será a mesma”.

O problema dos modelos regionais de crise é que a generalização de cada um deles tem limites que o impedem de se tornar critério único. A nossa questão inicial, portanto, resiste e uma outra abordagem é reclamada. O critério deve procurar-se noutro lugar.

Neste sentido, pela nossa parte, gostaríamos de sugerir a seguinte possibilidade: para entendemos determinada situação fora de nós e à nossa volta como "crise", é forçoso que encontremos primeiro "em nós" um modelo interior que permita, por analogia, viver, experimentar e compreender como crise determinado estado de coisas. É o que, a nosso ver, Ricoeur nos autoriza a pensar quando, ao procurar uma aproximação holística e não apenas analítica e fragmentada ao conceito de crise ${ }^{55}$, descobre "um encorajamento neste sentido nas filosofias existenciais que encontram a noção de crise como estrutura permanente da bumana conditio." 56 Neste contexto, são os nomes de Max Scheler, Paul Landsberg e Emanuel Mounier que surgem sob a pena do filósofo de Valence para recordar a que ponto "o conflito, a rutura, o risco" fazem parte da "conceção militante do homem comprometido". Segundo Paul Landsberg, nomeadamente, a pessoa desvenda-se sob os traços dramáticos de um ritmo existencial traçado entre "as forças da vida que a atraem para um êxtase negro e as forças espirituais que a atraem para um êxtase superior"; e, neste sentido, pode afirmar-se que a crise é "o entre dois, constitutivo da coragem de existir", não sendo descabido concluir que o "processo de personalização, enquanto conquista da singularidade e da diferença" parece, de algum modo, conter "em embrião todas as figuras parciais da crise" ${ }^{57}$.

Dir-se-ia, então, que um primeiro "barómetro" da crise se encontra na constituição oscilante de uma individualidade que luta por se reapossar de si própria e da sua ação na contraluz da possibilidade de não o conseguir sempre em todos os momentos - uma individualidade que, portanto, procura afirmar-se

\footnotetext{
55 Ibidem, p. 11

56 Ibidem, p. 11

57 Ibidem, p. 11
} 
mas constantemente se pode desolar de si própria, que procura perseverar no seu centro mas recorrentemente se pode arruinar, que procura conquistar-se mas frequentemente se reconhece devastada no centro do seu próprio existir.

A ser correta esta nossa assunção, o reconhecimento de dada situação social, política, ética, etc., como "de crise" terá sempre como primeiro critério, como primeiro modelo, um referencial autobiográfico - a história de uma vida que persevera no fio oscilante de um existir sempre precário, sempre construído sem pontos de apoio fixos dados à partida ou de uma vez por todas.

Pelo seu incomparável valor filosófico e carácter pioneiro, parece-nos ter a este respeito importância de exemplo paradigmático o texto do Journal intime de Maine Biran, filósofo francês injustamente esquecido que até ao ano da sua morte, em 1824, não cessou de testemunhar e interrogar filosoficamente as crises diárias da vigência perseverante da posse de si. Os exemplos encontram-se em praticamente todas as páginas desse texto tão especial. Anotemos apenas um exemplo: "Grateloup, 3 de setembro: (...) A mudança de temperatura afetou-me. Apanhei uma constipação que abate singularmente as minhas faculdades e me tira todo o equilíbrio, toda a firmeza de pensamento." 58 Em traços melancólicos, o filósofo de Bergerac espanta-se com a inconstância das condições propícias ao pensamento, surpreende-se com a sua contingência, eclipses e intermitências que parecem acompanhar as mais prosaicas circunstâncias diárias: uma digestão pesada, mudanças súbitas do clima, etc. E filosoficamente interroga-os com precisão: "a que ponto dependo eu de mim próprio?" Por que razão "não pensamos sempre"? Que significa esta estranha condição de por vezes "cessar de ser eu"?

As origens da recorrente crise da posse de si situa-as Biran no "fluxo perpétuo"59 de uma matéria sensitiva que se sucede, alterna e varia no corpo vivo da organização podendo interferir constante e continuamente ${ }^{60}$, com a "direção das nossas ideias e dos nossos pecados", da nossa vontade e do nosso corpo próprio. Assim varia a meteorologia da interioridade biraniana: tomba a organização na astenia e logo se regista "um dia triste; todas as minhas boas

\footnotetext{
58 MAINE de BIRAN, Journal intime, II, ed. La Baconnière, Neuchatel, 1955, p. 154.

59 Veja-se, por exemplo, MAINE de BIRAN, De l'aperception immédiate. Mémoire de Berlin, in Euvres de Maine de Biran, t. IV, ed. Vrin, Paris, p. 137, n.

60 Veja-se, por exemplo, MAINE de BIRAN Essai sur les fondements de la psychologie, II, Euvres, t. VII-2, ed. Vrin, Paris, p. 202.
} 
disposições vitais se desvaneceram; a humidade penetra-me e entristece-me" ${ }^{\prime 61}$; impera a inconsistência do corpo afetivo e há que registar os dias passados "num estado penoso de tristeza, de desencorajamento, de dificuldade e quase de ausência de vida" ${ }^{2}$; alvoroça-se o jogo das imagens e fluxos afetivos - que parece ter o seu centro no estômago ${ }^{63}$ - e eis que afluem todas as inconstâncias do humor, todas as faces do devaneio alucinado, todos os males da "doença da distração" "; ; abate-se em movimentos nervosos e dormentes a "máquina", e logo parecemos, no tumulto do mundo, os magnetizadores de nós próprios, cada qual deambulando "distraído e como um sonâmbulo neste mundo dos assuntos"65.

Esta última referência (recorrente) merece ser sublinhada. Biran reconhece que a crise da posse de si não é estranha à presença no "mundo dos assuntos", às influências da sociedade, à "órbita" dos outros, às transformações constantes do mundo da política. O barómetro do continente da interioridade do qual Biran desejou ser o "Colombo metafísico" também oscila ao ritmo da sociedade e das influências simpáticas dos outros, também balança com as cadências da vida social, com as suas convulsões, exigências e imposições. No centro de uma teoria da vida afetiva, e a partir da constatação da crise da posse de si, que o biranismo encontra o terreno da ética e da reflexão social e política.

Com esse terreno do "mundo dos assuntos", no entanto, Maine Biran manterá sempre uma relação paradoxal. Por um lado, relata diariamente os males que dele colhe a sua frágil saúde, os desajustamentos que o seu temperamento patenteia; por outro lado, não deixará de procurar uma vida política e uma presença pública. Várias entradas do Journal podem ilustrá-lo, mas eventualmente nenhuma de modo mais eloquente do que o episódio do "peditório para os pobres de Saint Sauveur". A Sra Duquesa de Rohan, acompanhada de Castel-Bajac, conhecido de Biran, vai a casa deste último para lhe pedir que contribua para os pobres e o nosso filósofo, nesse dia indisposto, sem firmeza, nervoso, contribui com seis francos que tinha preparado por esperar já a chegada da Duquesa. Ora, uma palavra da sua visita, referindo-se a outras pessoas que haviam contribuído com

\footnotetext{
61 MAINE de BIRAN, Journal, II, p. 163

62 Ibidem, p. 205.

63 Ibidem, p. 5.

64 Ibidem, p. 21.

65 Ibidem, p. 27.
} 
um ou dois Luíses, será suficiente para que Biran imediatamente comece a pensar que a sua esmola foi vergonhosamente pequena. Fica paralisado. Nada mais fará durante o dia senão pensar neste assunto: o que pensarão dele, para mais um homem político, com responsabilidades e respeitado? Como retificar tal gesto ridiculamente avaro? Tornar-se-á na anedota da sociedade. Permanentemente inquieto chegará a passar em frente à casa da Duquesa, mas não conseguirá entrar. Não sabe o que dizer, como dizer. Apenas após o jantar, quando o acaso o leva a encontrar a benemérita e lhe diz que deseja aumentar o seu contributo, apenas então ficará descansado ${ }^{66}$.

O episódio é revelador da personalidade melancólica, depressiva e quase patologicamente insegura de Biran ; mas não é por isso que se trata de um passo importante do Journal. Ele é interessante a vários níveis. Primeiro, por nos obrigar a pensar a que ponto a vida afetiva marca a nossa primeira "entrada" no mundo e, ao mesmo tempo, a que ponto o mundo e os outros podem influir, sem controlo da nossa consciência, sobre o nosso temperamento e sobre os equilíbrios da nossa interioridade. Depois, por nos oferecer - como viu A. Antoine no seu pequeno mas estimulante texto intitulado Maine de Biran. Sujet et politique $e^{67}$ - uma significativa prefiguração do "tipo novo de homem democrático do qual Tocqueville fará magistralmente a teoria na sua segunda [parte] de Démocratie en Amérique." 68 O que caracteriza a nova sociedade americana é o facto de desenhar uma ordem sem "ordens sociais", sem classes, corporações ou privilégios de nascença e de se fundar na universalidade e igualdade dos valores individuais. O mesmo é dizer que a afirmação do "eu" passa a ser um direito universal, mas também precisamente por isso uma conquista perpétua contra a multidão de iguais; é necessário medir-nos constantemente entre todos, procurar a aceitação do outro, lutar pelo seu apoio, procurar partilhar os mesmos valores e assumir que se está sempre sob o olhar avaliador de alguém que partilha os mesmos direitos e oportunidades. Que este esforço encerra algo de perturbador é o que já Maine de Biran testemunha na primeira pessoa: "O sentimento da minha fraqueza faz com que experimente, mais do que qualquer outra, a necessidade de ser apoiado, de estar em paz com todo o mundo, de

\footnotetext{
66 Ibidem, I, p. 186.

67 ANTOINE Agnès, Maine de Biran. Sujet et politique, P. U.F., Paris, 1999, pp. 38 e ss.

68 Ibidem, pp. 41-42
} 
inspirar a benevolência de cada um (...). Quando estou na dúvida do sucesso, o medo atormenta-me; se julgo notar alguma indiferença ou menosprezo, entro em suplício; eis um escravo completo." ${ }^{" 69}$ A experiência de Biran numa sociedade em convulsão é a de se sentir fora do seu lugar e do seu tempo; sente que - diríamos, jogando com o título famoso de Max Scheler O lugar do homem no cosmos - não tem naturalmente um lugar no "cosmos" social e político. "Não conheço bem o meu lugar - escreve Biran - o instinto variável de fraqueza ou de força mostra-mo ora mais alto, ora mais baixo"70

Com Biran percebemos que o homem da sociedade, submetido ao olhar avaliador do outro ${ }^{71}$, tomado pelos cegos desígnios das simpatias, é fundamentalmente um ser inquieto, melancólico, perturbado, que constantemente se comparara com os iguais e julgando nunca estar "à altura"72, continuamente convocado pelas obrigações sociais mas "desencantado do mundo"73 na contraluz de uma ausência de pontos de apoio seguros para se conquistar a si próprio na diferença - enfim, alguém forçado a participar de uma "exterioridade" que reforça a evidência interior de que a conquista de si, o reapossamento, o perseverar no seu centro é uma tarefa penosa, árdua e cheia de dificuldades.

O sujeito biraniano traz consigo a crise. E esta corresponde ao sentimento de desequilíbrio recorrente ante a necessidade constante de superar, sob o olhar avaliador dos outros, todo o tipo de alternativas que reclamam uma decisão, de abismos que carecem de uma ligação, de ruturas que exigem uma ordem. E a insegurança constante torna-se assim pasto do pressentimento de poder "cessar de ser eu", do bloqueio ou dormência da reflexão impedindo a concentração e a posse de si e, no limite, da experiência melancólica de oscilar entre o perseverar na posse de si e o desapossamento imposto pelo fluxo de uma vida em mim sem

69 MAINE de BIRAN, Journal I, p. 198. Cf. ANTOINE Agnès, Maine de Biran ..., p. 39 e ss.

70 Ibidem, II, p. 86.

71 Ibidem, I, p. 198

72 Ibidem, II, p. 90: «Je me sens plus faible au milieu de tant d'hommes forts ; je ne me mets pas en rapport avec eux ; je cesse d'être moi sans me confondre avec les autres; le moindre signe d'opposition ou seulement d'indifférence me trouble et m'abat. Je perds toute présence d'esprit, tout sentiment et toute apparence de dignité. Je sens que les autres doivent avoir une pauvre idée de mon chétif individu et cette persuasion me rend plus chétif, plus timide et plus faible encore. Je devrais renoncer aux grandes assemblées et à la vie publique ou extérieure ; j'y suis le moins propre de tous les hommes."

73 Ibidem, II, p. 208. Cf. DEVARIEUX, A., Maine de Biran. L'individualité persévérante, Millon, 2004, p. 372. 
mim, entre as condições para se concentrar e as circunstâncias que desconcentram, magnetizam, alienam e roubam o tempo do eu.

\section{Crise, tempo e afirmação}

Com Biran encontrámos um primeiro critério em nós para perceber o que é uma crise: esse critério encontra-se ligado ao sentimento de não saber qual o nosso lugar no mundo, à insegurança de não saber sempre e em todas as circunstâncias que hierarquia de valores pode conduzir as decisões, à inquietação de não poder dominar as influências dos outros ou conseguir distinguir claramente quem são os amigos e os adversários, ao desassossego de não nos possuirmos sempre e em todos os momentos no meio das múltiplas influências que vêm perturbar o existir perseverante. E assim dir-se-ia que um primeiro núcleo da crise se encontra sempre nas encruzilhadas onde o esforço para perseverar esperançadamente no nosso existir é cruzado por tendências sonâmbulas, de inércia, de desistência, de fuga ou de queda.

$\mathrm{Na}$ via de um aprofundamento da crise e da nossa procura de um critério distintivo, tais considerações não completam, no entanto, a nossa análise.

É necessário constatar, também do "lado de fora", o que faz determinada situação aparecer a um sujeito como "crise", pois se o único critério fosse, de facto, o existencial, a crise seria um estado permanente de todos e de cada um e, nesse caso, como diria P. Ricoeur, tudo sendo crise, nada seria crise. ${ }^{74} \mathrm{Em}$ função do que fica dito, não faria certamente sentido supor que se reconhece como situação de crise "fora de nós" algo de radicalmente diferente do que se vive como crise em nós; mas para completar o nosso critério identificador de crise é ainda necessário saber se algo do que foi dito sobre o plano pessoal pode ser transposto para o plano da realidade social e fornecer pistas para descobrir um critério ao mesmo tempo universal e transtemporal de crise, com o qual seja pertinente caracterizar um determinado período ou contexto histórico-social ${ }^{75}$.

74 RICOEUR, P., "La crise, ...", p. 12.

75 Ibidem, p. 13. Ricoeur propõe-nos este caminho na esteira de Landsberg e Mounier ; nós procurámos fazer o mesmo caminho a partir de Maine de Biran. 
A análise que vimos desenvolvendo do critério existencial de crise oferece-nos, nesse sentido, uma dupla indicação que merece ser explorada: por um lado a ligação entre crise e tempo ou temporalização; por outro, a ligação entre crise e firmeza ou afirmação.

Consideremos a primeira destas indicações, recordando a angústia de Biran aquando do episódio com a Duquesa de Rohan. Essa angústia guarda algo que não é apenas próprio do indivíduo Maine de Biran, mas revelador da condição humana - de uma condição que é marcada pelo conflito de se querer ser si mesmo num mundo com outros. "Olho-me, vejo-me nas minhas ações e julgo-me" à luz da imagem que terei de mim mesmo e do que os outros poderão vir a pensar de mim. E por isso sou crise no sentido em que, para mim, reapossar-me da minha personalidade é sempre algo que acontece num presente que é, ao mesmo tempo, passado recente e futuro iminente. Quando me olho e me julgo na minha situação, faço-o sempre, pois, apropriando-me das minhas ações ainda presentes mas já repercutindo-se numa imagem - de desproporção - que é o meu ser futuro ${ }^{76}$.

Num certo sentido, é esta estrutura de temporalização que, como mostra Ricoeur, pode ser transposta para o âmbito global da consciência histórica ao mesmo tempo acentuando, fazendo variar produtivamente e relativizando a polaridade, proposta por Koselleck, entre "horizonte de espera" e "espaço de experiência" ${ }^{\prime 7}$. Nesta relação, onde o aluno de Heidegger faz ressoar a distinção augustiniana entre presente do passado - a memória - e presente do futuro - a espera -, as duas categorias históricas destacadas são assim ponderadas: o "espaço de experiência" corresponde ao "passado atual cujos acontecimentos foram integrados e podem ser rememorados ${ }^{78}$; o "horizonte de espera" designa a preocupação pelo futuro e liga-se "ao que-ainda-não-é, ao que-não-é-do-espaço-de-experiência, ao que-não-é-ainda-senão-expectável."79 E o centro da análise é localizado na distância que existe entre os dois, fazendo do presente um movimento de temporalização que avança à medida da tensão entre o realizado

76 Ibidem, p. 12.

77 Ibidem, p. 13.

78 KOSELLECK, R., Le futur passé, contribution à la sémantique dês temps historiques, (trad. franc.), Editions de l'Ehess, 1990, p. 311.

79 Ibidem, p. 311, Cf. CERCLET, D., "Le corps en mouvement comme lieu de constitution du temps?», in BERTHOZ, A. ANDRIEU, B., (dir.) Le corps en acte, P. U.N., 2010, p. 174. 
no campo de experiência e o realizável no horizonte de espera. Nestas categorias, que entrecruza com as suas análises da ideologia e da utopia, Ricoeur crê encontrar o ponto de apoio para meditar um conceito "ao mesmo tempo geral e determinado da crise". Tal conceito resume-o o filósofo neste termos: "quando o espaço de experiência se estreita por causa de uma negação geral de toda a tradição, de qualquer herança, e o horizonte de espera tende a recuar para um futuro cada vez mais vago e mais indistinto, apenas povoado de 'ucronias' sem influência sobre o curso efetivo da história, então a tensão entre horizonte de espera e espaço de experiência torna-se rutura, sisma." ${ }^{80}$

Neste sentido, então, a crise será como que uma "patologia do processo de temporalização da história", que se pressente existencialmente como sentimento claustrofóbico, como vivência de uma rutura bloqueadora do processo de temporalização pessoal, como abismo entre o realizado e o realizável. Dito de outro modo, crise é, ainda segundo Ricoeur, "uma disfunção da relação normalmente tensa entre horizonte de espera e espaço de experiência." ${ }^{81}$ Pode ser dito de crise, pois, um contexto social ou político onde as forças perseverantes do presente e as memórias do realizado não vislumbram no horizonte de futuro senão forças de inércia, de repetição, de deserção, forças incapazes de pôr em marcha as promessas que se desenham no "presente do futuro", ou de sequer abrir espaço ao poder transformador da imaginação.

O que nos leva à segunda indicação do critério existencial de crise que propusemos: o sentimento de recorrente falta de firmeza, de pontos de apoio que disponibilizem o plano de consistência necessário ao reapossamento das possibilidades humanas de existir. Com o critério existencial, reconhecemos a crise na oscilação melancólica entre momentos de concentração e posse de si e momentos de "perda do seu centro". Neste sentido, poderia dizer-se que o reconhecimento da crise se liga à consciência de poder não ser si mesmo em todos os momentos, ao escândalo de, subitamente e sem aviso, podermos perder-nos de nós próprios; mas também à estranheza de nos reconhecermos depois de não ter sido. Assim se constrói um existir constantemente averiguado entre o que se conquista de si e subitamente se pode perder, constantemente medido entre a

\footnotetext{
${ }^{80}$ RICOEUR, P., "La crise, ...", p. 13

81 Ibidem, p. 14.
} 
firmeza do que se alcança e o pressentimento da sua precariedade cujas causas "em mim" permanecem refractárias à consciência.

De algum modo, esta estrutura de oscilação precária dos pontos de apoio, variando, segundo Biran, entre o exercício da vontade e a influência selvagem do fluxo afetivo - onde se pressagia a preponderância cega da vida e dos outros - pode ser transposta para o âmbito global da consciência histórica acentuando aquilo a que D. Innerarity chamou, na contraluz de uma ideia de história como "peculiarização", a "aprendizagem da contingência." ${ }^{2}$ Não só os sujeitos, mas também as instituições e os sistemas sociais, têm um carácter e uma história não em função das suas intenções (ou da sua vontade) mas, em grande parte, "por efeito da intervenção das intenções de outros e dos acontecimentos contingentes para os quais não estão programados." ${ }^{83} \mathrm{O}$ aparecimento e comportamento destes últimos são "aleatórios em relação às intenções, planos e evolução normal do sujeito" ${ }^{84}$, muitas vezes manifestando propriedades anómalas e surgindo de inesperadas combinações singulares que frustram amiúde as expectativas da vontade. O sentimento de crise cresce nestes esgueires de inesperado, de insegurança, de efetiva desconcentração resultante de um processo histórico impossível de padronizar e calcular sem erro. Numa palavra, longe de sermos os mestres e possuidores da nossa história, são antes aqueles processos em grande parte aleatórios e que escapam às expectativas, que se furtam à previsão, ou subvertem as regras e o habitual que nos mostram quem somos ${ }^{85}$.

Por isto se compreende que o modo que corresponde à história não poderia senão ser narrativo ${ }^{86}$ : porque apenas a narrativa guarda o poder de integrar coerentemente os acontecimentos que não encaixam em qualquer modelo teórico, que subvertem qualquer expectativa racional, qualquer padronização. Por isso quando por exemplo "alguém se procura desculpar, costuma contar uma história; isto é: remete-nos para circunstâncias que não obedecem às razões da sua ação." ${ }^{87}$ Tal não significa, no entanto, que tal história nos possa "exonerar

\footnotetext{
82 INNERARITY, D., O Novo Espaço Público (trad. port.), ed. Teorema, 2006, pp. 187 e ss.

83 Ibidem, p. 185.

84 Ibidem, p. 188.

85 Cf. Ibidem, p. 191.

86 Ibidem, p. 189.

87 Ibidem, p. 188.
} 
do difícil exercício das nossas liberdades"; longe disso, a lição a retirar do gesto narrativo é a de que devemos moderar as certezas sobre o futuro, libertar-nos da ilusão de que dado "sinal da história" revela mais necessidade do que simples acaso, mais firmeza do que apenas variação - e compreender que o futuro se mantém aberto como realidade não exaurível e nunca definitivamente firme.

Assim, o mais apreciável ensinamento da dimensão narrativa da história seria o de nos tornar possível "adivinhar quão indeterminadas estão as possibilidades do que viermos a ser" ${ }^{\prime 8}$. E, neste sentido, o critério da crise seria o de uma "patologização" do carácter aberto da história: ou melhor a ocupação do seu carácter de abertura quer pela pura incerteza, face à qual se cai na desistência alienante, quer pelo vazio de possibilidades razoáveis, ante o qual sucumbem a vontade e a projeção de possíveis. A crise seria, portanto, de um modo ou de outro, uma situação de carência de possibilidades de fazer sentido orientador o que permite afirmar que neste contexto se jogam sempre, como viu Ricoeur, três traços que podemos recuperar do modelo médico de crise: a) uma patologia cujo sintoma principal é o de um mal-estar, o de um sofrimento que resulta da aparente impossibilidade de integrar os acontecimentos passados num espaço de experiência presente, em vista de uma antecipação orientadora do futuro; b) um constante ciclo de ruturas, de quedas súbitas, que tornam impossível a consistência do tempo; c) a expectativa sempre adiada de um diagnóstico convincente; d) a oscilação constante entre a esperança de cura e a fatalidade do fim.

\section{Filosofia, crise e sentido}

Mas como enfrentar tais situações? Ou seja: qual a solução para a crise? Este questionamento, esperado por todos os conferencistas, pode ser formulado em vários tons, como reconheceu ironicamente N. Postman: há aqueles que perguntam com grande ansiedade, supondo que o conferencista conhece as soluções tão bem como os problemas mas não as quer revelar; há aqueles que perguntam ameaçadoramente, certos de que o conferencista não deveria sequer ter aparecido para maçar as pessoas sem uma resposta pronta e definitiva para os problemas

88 Ibidem, p. 191. 
que formula; e, finalmente, há aqueles que perguntam de modo encorajador, reconhecendo que para problemas tão complexos não há soluções simples, mas que, ainda assim, do debate crítico alguma orientação, algum sentido, pode emergir $^{89}$. A estes últimos me atreverei propor algumas notas orientadoras, que mais não farão, seguramente, do que mostrar a minha própria perplexidade e desorientação ante a dificuldade do problema debatido.

Uma primeira nota orientadora pretende chamar a atenção para o seguinte facto: no centro da crise, onde nascem as suas forças mais paralisantes, mais alienadoras, mais negadoras de futuro, também nasce o que nos pode salvar: a vocação da crise para se oferecer como ocasião de questionamento das aparências, de investigação crítica do que realmente vale, de transformação de princípios e normas, de renovação das tradições mais férteis e dos caminhos que guardam mais promessas de futuro. Há que aprofundar a crise, pois, no sentido de assumir o seu escândalo como ocasião de crítica - de crítica às formas empobrecidas de fazer sentido que tendem a reduzir o inacabamento próprio do futuro à aridez do mesmo.

Segunda nota: tal capacidade de crítica exige o esforço de uma aprofundada compreensão dos problemas, de uma complexificação dos discursos e de densificação de possibilidades novas de sentido. Dir-se-ia que uma situação de crise reclama Filosofia enquanto esta sempre se propõe como saber que: a) se compromete com a autenticidade; b) critica a aparência, o banal e o monótono; c) afirma e defende a irredutibilidade da diferença; c) nega a uniformização do sentido sob a forma de produto, função ou mercadoria.

Terceira nota: o esforço de complexificação filosófica deverá estar ao serviço de uma aproximação epistemológica e psíquica à ideia de que não há apenas um único sistema de pensamentos capaz de produzir a verdade, de propor o progresso e de aumentar a posse de si, mas vários. O mesmo é dizer que devemos encarar seriamente as propostas das grandes análises filosóficas, como das grandes narrativas literárias, históricas e religiosas, devemos ouvir o que nelas ainda nos fala e pode contribuir para compreender a nossa situação presente

89 POSTMAn, N., Tecnopolia (trad. port.), ed. Difusão Cultural, 1994, p. 160. Este texto foi ainda inspirador de alguns aspetos das notas que se seguem. 
sempre aberta a um futuro por fazer - numa palavra devemos aplicá-las (no sentido hermenêutico do termo) a uma causa que valha a pena.

Quarta e última nota: encarar tais propostas e procurar apropriá-las, aplicá-las à orientação da ação, conduzirá a reconhecer não ser mais possível dar demasiada atenção às opções de sentido empobrecido (derivadas de sondagens, estudos de opinião, ratings, racionalização burocrática, lixo televisivo, excesso de informação superficial, monotonia do politicamente correto, estagnação do discurso político, desorientação do discurso económico, compartimentação artificial de saberes, má literatura, arte desinteressante, etc.) sem interpretar cuidadosamente os respetivos pressupostos, preconceitos e, principalmente, limites. Neste sentido, é necessária uma dupla tarefa quotidiana: por um lado, preservar a capacidade crítica e o pensamento razoável; por outro, recusar o critério da eficácia como prioritário na determinação das relações humanas, da organização do estado, e da educação do pensar. 
Pedro M. S. Alves

Universidade de Lisboa

\section{Tem o diagnóstico fenomenológico}

DA CRISE UMA LEITURA POLÍtica?

1. Não vou falar abstrata ou sibilinamente sobre crises em geral, ou sobre o conceito de crise - que não é, sequer, uma categoria forte do pensamento político, ao contrário do conceito de revolução -, ou ainda sobre uma qualquer crise do passado, próximo ou remoto. Vou falar diretamente do sentimento difuso de mal-estar que hoje em dia atravessa a nossa vida coletiva e que se exprime em múltiplos sinais. E fá-lo-ei não em função de qualquer cartilha político-ideológica, seja a liberal, a marxista, a conservadora ou outra, que já têm, todas elas, um diagnóstico da crise pronto a servir e um curativo também pronto a aplicar, mas tentando, na medida do possível, interrogar a própria natureza de uma comunidade política enquanto tal. Para isso, socorrer-me-ei - coisa inusitada e, para muitos, aberrante - do método fenomenológico de abordagem, para com ele intentar caracterizar o sentido do Político e obter também, a partir daí, um significado mais bem definido para o próprio conceito de crise.

Falemos dos sinais, difusos, de um mal-estar sempre crescente. Seja dito desde já que, ao falar de um mal-estar, não me refiro às múltiplas peripécias de comportamentos lamentáveis de muitos atores políticos, que dão origem a uma perceção quase criminal da atividade política. Refiro-me, mais profundamente do que esta quebra de confiança dos cidadãos nos atores políticos atuais, que será certamente fruto de uma generalização abusiva, ao fenómeno de fundo de que ela é, em minha opinião, a expressão incorreta e deslocada: a perda de confiança, por parte dos cidadãos, nas suas próprias instituições políticas, ou seja, a perda de confiança no próprio sistema através do qual uma comunidade se governa a si própria. Mais fundo do que um desencanto com os políticos, 
gritado nas ruas em palavras cortantes, ouvem-se, em surdina, as vozes de um desencanto com a própria Política como tal. E este mal-estar significa a abertura de uma cisão entre a comunidade e as instituições pelas quais ela decide a sua vida coletiva. Este estranhamento, que não é alheamento indiferente, mas perceção de uma profunda disfunção do próprio sistema, é, a meu ver, o que de mais fundo e perturbador há na situação de hoje em dia. E os sinais de que falava são múltiplos. Por exemplo, a ideia de que os representantes do Povo se tornaram uma espécie de classe profissional, com os seus interesses particulares próprios; ou a ideia de que o sistema político está aprisionado pelas instituições partidárias e serve os seus interesses, como se estas fossem sociedades particulares relativamente ao interesse geral; ou ainda a ideia de que o sistema político se hipertrofiou, a ponto de haver um número excessivo de atores; ou também a ideia de que o sistema político toma más decisões ou decisões fora de tempo, pelo que não é nem oportuno nem eficaz.

Todos estes sinais conduzem a perguntas inquietantes. Refiro algumas:

1. Até que ponto o sistema político que construímos ao longo das quatro últimas décadas é eficaz para assegurar o nosso autogoverno?

2. E não será a perda de eficácia eo ipso uma perda de legitimidade?

3. Tem o Povo o direito de alterar a sua Constituição, ou seja, o sistema político pelo qual se rege?

4. E poderá fazê-lo de outro modo que por revolução?

Isto digo para já sobre a crise hodierna da nossa vida coletiva. Falarei agora sobre a Fenomenologia. Em boa verdade, a Fenomenologia sempre teve pouco ou nada para dizer sobre a Política. Não há uma fenomenologia do Político, não há sequer, com a notável exceção de Alfred Schütz, uma teoria fenomenológica da sociedade e, ainda menos, uma teoria fenomenológica dos processos económicos e organizacionais de reprodução da vida material. Não há também, na Fenomenologia, por maioria de razão, uma visão sobre essas ruturas na vida coletiva que denominamos por "crise".

Muitos dirão que não tem de haver uma tal extensão da Fenomenologia, pelo menos daquela que se inscreve na matriz husserliana. Para quem sustenta este 
ponto de vista, essa lacuna justificar-se-ia por uma razão essencial. Os métodos de redução ou limitam a Fenomenologia a uma teoria das essências, portanto, a um a priori material e formal desligado dos acidentes da vida factual e histórica, ou a acantonam no ego transcendental liberado pela epoché, o qual é uma base demasiado estreita para abarcar processos sociais e políticos, que são, por natureza, coletivos e meta-egológicos.

No entanto, quero aqui sustentar duas coisas contra esta maneira de entender a Fenomenologia. Primeiro, direi que há, desde a origem, uma teoria fenomenológica e um diagnóstico fenomenológico da crise; segundo, contrariando a opinião dominante, direi que uma fenomenologia do Político é não só possível como desejável, na medida em que uma descrição fenomenológica do sentido do fenómeno político poderá lançar luz sobre algumas raízes da crise hodierna que permanecem invisíveis para outras abordagens.

É isso que ensaiarei no que se segue. Desenvolverei o diagnóstico fenomenológico da crise da humanidade europeia para, a partir dele, me interrogar sobre o sentido do fenómeno político e, a essa luz, sobre algumas razões, de outro modo menos visíveis, da crise da nossa vida coletiva.

Este será o meu contributo para o aprofundamento - não para o agravamento, espero... - da crise, que é tema deste colóquio.

2. Sob a designação de "diagnóstico fenomenológico da crise" refiro-me, aqui, ao conjunto de teses e de apreciações que Edmund Husserl apresentou na sua célebre conferência de 1935, em Viena, intitulada "A Crise da Humanidade Europeia e a Filosofia”. A conferência versava sobre o significado espiritual da Europa (ou do Ocidente), sobre o nascimento, com os Gregos, da atitude puramente teorética perante o mundo e, finalmente, sobre o modo como esta atitude criara, através das ciências, que são o seu desenvolvimento, uma comunidade de tipo novo, dotada de um carácter supranacional e aberta sobre tarefas infinitas.

Uma teoria é uma idealidade. É um conjunto de proposições, concatenadas segundo métodos internos de validação, que, em conjunto, pretendem descrever aquilo que é. Uma teoria é uma unidade de sentido sempre disponível, que pode ser indefinidamente repetida e desenvolvida em novos atos do pensamento teorético. É justamente isso que faz dela uma idealidade. As tarefas infinitas 
de que Husserl falava nessa conferência eram precisamente esses processos de construção de sempre novas idealidades teóricas por sobre as idealidades já instituídas, num movimento de receção compreensiva e de crítica permanente. Era assim que ciências como a Geometria, a Álgebra, a Lógica, a Física, ou qualquer outra, se constituíam, desde a sua fundação originária, como tarefas sempre em aberto e jamais cristalizáveis sob uma forma final definitiva. Assim, não haveria jamais qualquer coisa como $a$ Geometria, entendendo-se com isso um corpo teórico definitivamente terminado. A Geometria seria, antes, a tarefa de uma progressão infindável do pensamento geométrico. E o mesmo para todas as outras ciências, que dimanavam do que chamamos "Filosofia", palavra que Husserl entendia, aí, como o nome cunhado pelos Gregos antigos para designar esta atitude puramente teórica perante o mundo e a forma cultural dela resultante. Era nesta comunidade dos homens que dedicavam porções da sua vida fática à atitude puramente teórica, à comunicação e crítica recíprocas, que Husserl divisava o nascimento de uma comunidade humana de tipo novo, que vencia as incompreensões entre culturas e as barreiras políticas entre nações para se constituir como uma comunidade supranacional. O significado espiritual da Europa teria sido precisamente esta comunidade supranacional aberta sobre a tarefa infinita do conhecimento da Verdade. E o conhecimento da verdade constituía a expressão mais própria da cultura da Razão.

Como é bem visível, esta comunidade supranacional dos "filósofos", em sentido lato, não tem configuração política possível. Ela não envolve os múltiplos planos da vida social e material das comunidades humanas. Ao contrário do devaneio de Husserl sobre um "Povo mundial" e um "Estado mundial", no fim do quarto artigo que escreveu para a revista Kaizo, a ideia de uma comunidade supranacional dos filósofos não tem, só por si, modo político de formulação. É certo que Husserl declarava na conferência que a tarefa infinita da Verdade, uma vez descoberta, permitia a irrupção de outras tarefas infinitas, que retiravam da primeira o seu estilo e que cobriam outros aspetos da vida fática dos homens e dos povos. A esta luz, a Justiça poderia bem ser entendida como uma tarefa infinita da esfera político-jurídica. E o mesmo para o Bem, na vida ética individual. Fora justamente nesse sentido que ele o entendera, aliás, quando alargou o conceito de Razão também a um exercício prático, que já não estava apontado à Verdade, mas a uma vida, tanto individual como social, regida por normas de 
validade absoluta. No entanto, este alargamento do conceito de uma cultura da Razão não conduz, por si só, a uma figura definida para a comunidade política. Da Filosofia, ou seja, da atitude puramente teórica perante o mundo, e da ideia de uma vida autêntica, sob normas racionais absolutamente válidas, não brota por si só uma Política. Dito com mais precisão: não brota nem uma forma definida para a vida em comunidade nem uma configuração determinada para as instituições "políades", se assim me posso exprimir, ou seja, para as formas organizativas concretas em que a pólis se realiza.

Diremos, então, que, neste contexto, o diagnóstico fenomenológico da crise, qualquer que ele seja - e ainda não dissemos qual é -, será sempre irrelevante do ponto de vista político? Não o creio. Por duas razões conjugadas.

Primeiro, é minha convicção que o diagnóstico husserliano da crise tem uma motivação diretamente política. De facto, tirando a crise dos fundamentos da Matemática e, eventualmente, as sequelas de uma discussão áspera sobre a interpretação do formalismo quântico, não há, em 1935, qualquer crise interna nas ciências. O que há, o que é visível por toda parte, é uma crise da humanidade (Husserl fala de Menschentum) europeia, para a qual Husserl julga poder encontrar a causa última num desenvolvimento unilateral da racionalidade científica que teria ocorrido na Modernidade. E essa crise da humanidade europeia que se depara a Husserl é bem fácil de documentar. De facto, sobre o ano de 35 projeta-se a sombra de várias catástrofes. Há desde logo a crise económica e financeira que devastou a Europa na sequência do crash bolsista de 1929; há ainda o colapso, na Alemanha, da República de Weimar e, com ele, da democracia parlamentar no estilo liberal; há, finalmente, desde março de 33, com o Ermächtigungsgesetz, uma alteração do próprio princípio de governação, com a suspensão da Constituição e a concessão de poderes ao Chanceler para legislar sem intervenção do Reichstag. A devastação da vida material, a desagregação da sociedade, a alteração radical do modo de governação - na Alemanha e não só -, alteração que se despoleta uma interrogação em profundidade sobre a própria natureza do político, são o contexto e, a meu ver, a motivação direta para afirmação de que há uma crise da humanidade europeia.

A segunda razão é que a etiologia que Husserl faz da crise só ganha sentido precisamente neste contexto. De facto, no momento em que a os mecanismos da vida material e o próprio princípio de organização da comunidade 
política estavam em questão, no momento em que as antigas convicções se tornavam questionáveis, Husserl voltava-se para as ciências humanas - as então chamadas Geisteswissenschaften - no sentido de obter delas uma resposta e uma guia racional segura. No entanto, as ciências humanas, de onde princípios normativos para a configuração da vida ativa, tanto individual como coletiva, deveriam brotar, estavam mudas, nada diziam, não prestavam o serviço que supostamente deveriam prestar. De onde vinha esta falha? Eis a resposta de Husserl: do facto, funesto, de as ciências humanas terem seguido, na Modernidade, o modelo das ciências da natureza e de terem procedido a uma interpretação naturalista do espírito, como realidade dependente e subordinada ao mundo da corporalidade. Daí que elas se tivessem desenvolvido como meras ciências dos factos do homem e da sociedade, daí que elas tivessem remetido as causas últimas desses factos para a infraestrutura psicofísica e para a realidade material descrita pela Biologia, pela Química e pela Física, sem jamais terem apreendido tais factos como realizações de leis puras do domínio espiritual e de terem descoberto, por essa via, o plano das ciências apriorísticas da essência do Homem e da sua vida em comunidade. A humanidade europeia estaria, afinal, mergulhada numa crise porque as ciências do homem não teriam cumprido o seu papel, alçando-se dos factos até o nível de uma aclaração principial do eidos Homem e Sociedade, e, em retorno, não teriam podido, também, exercer uma crítica dos factos à luz desse conhecimento de essência. O conhecimento teorético foi, nelas, simples conhecimento de facticidades empíricas, o nível da teoria pura e das leis de essência não foi sequer entrevisto e, em consequência, nenhum princípio normativo de validade absoluta pôde delas brotar. Era nesta incapacidade das ciências do espírito para fornecer normas fundadas num conhecimento apriorístico de leis de essência que Husserl via a razão, remota mas ainda atuante, para a crise da Humanidade europeia.

Eis assim o que estava em questão no diagnóstico fenomenológico da crise: o que Husserl denominava como Naturalismo e Objetivismo, ou seja, a extensão de um certo modelo da racionalidade físico-natural à esfera da vida subjetiva e, por esse motivo, a elisão de uma verdadeira ciência racional, apriorística, da essência do homem, da vida social e da comunidade humana enquanto tais. 
3. Como disse, não é a crise de outrora que me interessa, mas a hodierna. No entanto, não deixa de haver entre as duas surpreendentes semelhanças: a atual situação de pré-colapso financeiro à escala global só teve precedente precisamente na situação vivida em 29, a que se acrescenta, ontem como hoje, o descrédito crescente, tanto intramuros como alhures, do sistema político, que conduz a uma interrogação sobre o que seja governar e sobre o princípio constitutivo da vida comunitária. É sobre estes últimos aspectos que me deterei no que se segue.

Para os tratar, pergunto: perante tal parentesco, será ainda instrutivo hoje em dia o que a Fenomenologia teve outrora para dizer sobre a crise? A minha resposta é a seguinte: sim, é instrutivo; e acrescento: talvez que a Fenomenologia não tenha mesmo mergulhado tão fundo quanto seria necessário para pôr a nu as raízes da crise que estão contidas na Modernidade, e talvez que estas duas crises, em que o colapso da vida económico-material se conjugou com uma crise da própria vida social e política, sejam dois afloramentos de uma mesma situação profunda e persistente.

Eis, então, o modo como entendo a razão profunda para a situação de pré-falência do sistema político. A questão não será tanto o Naturalismo e o Objetivismo na compreensão do homem, ou seja, a exportação da metodologia e da ontologia da ciência matemática da natureza para as ciências do homem e da sociedade; a questão reside, mais fundo do que isso, no modo como a Modernidade compreendeu a natureza do Político e o princípio da Soberania a partir de um modelo de racionalidade analítica e linear, que se constituíra em torno das ciências matemáticas da Natureza, particularmente da Física. Se isto for correto, antevê-se, também, o modo como uma explicitação fenomenológica da essência do Político poderia dar um bom contributo para a compreensão da crise hodierna, trazendo à luz as suas causas mais ignotas.

Passo à explicação do meu ponto de vista. Na génese e configuração das ciências da Modernidade, foi a Física, proveniente de Galileu e de Descartes, que desempenhou o papel de ciência diretora, e, dentro da Física, o desenvolvimento principal deu-se em torno da Mecânica. A Mecânica, porém, devido à sua orientação exclusiva para o estudo de sistemas sujeitos a deslocações provenientes da aplicação de forças, deu origem a um modelo de inteligibilidade a que chamo "analítico e linear", modelo de inteligibilidade em que, por um lado, um sistema pode ser sempre decomposto nos elementos simples que o integram, os quais 
podem existir isoladamente, e em que, por outro, o comportamento global do sistema pode ser sempre explicado como resultado do comportamento dos elementos que o compõem. Numa palavra, os elementos são anteriores ao todo e as propriedades do todo são redutíveis às formas de interação dos elementos; nada há como elementos que só possam existir como partes do todo e nada há como propriedades do todo que não sejam redutíveis ao comportamento das partes. Este modelo de inteligibilidade não é intrínseco à Ciência da Natureza. Nem sequer lhe será sempre aplicável. Ele é-lhe conveniente quando, da Natureza, apenas o sistema de movimentos locais e o dinamismo das forças interessa, de tal modo que o ente físico é considerado apenas como um corpo dotado de massa, submetido às leis de inércia e de comunicação de movimento. Esse modelo falha já, dentro da própria Ciência da Natureza, quando se lida com fenómenos complexos de organização, em que o todo não é nem decomponível nem redutível ao comportamento atómico das suas partes. A vida é apenas um caso de inaplicabilidade do modelo analítico e linear. E uma visão anticartesiana da vida, ou seja, não-mecânica, é uma tese explicitada desde muito cedo, pelo menos desde Leibniz. "Sou da opinião ... que as leis da Mecânica, por si só, não poderiam formar um animal, quando não houvesse ainda nada organizado", afirma este, referindo Cudworth. Mas há ainda uma profusão de outros domínios em que a complexidade é irredutível à linearidade. No entanto, o que importa frisar é que, no dealbar da Modernidade, esse modelo realizou uma abstração sobre a complexidade do real físico: reduziu-o a um sistema de corpos em movimento, e sobre ele aplicou, com o bom sucesso que se conhece, a inteligibilidade analítico-linear, mas com a pretensão reducionista excessiva - e, aliás, desde cedo controvertida - de que todos os demais problemas poderiam ser tratados introduzindo apenas um maior número de variáveis neste modelo, que tão boas provas dera já para a Mecânica e domínios afins.

A minha hipótese é que o pensamento político moderno, na própria formulação do seu tema, transpôs ingenuamente este modelo de inteligibilidade e que, em consequência, passou ao lado de uma compreensão em profundidade da essência do Político, para a qual ele não é de todo aplicável.

O caso flagrante é Thomas Hobbes, o pensador que dá a forma e a direção de fundo para o pensamento político moderno. A transposição começa desde logo na sua visão materialista e fisicalista da natureza humana, que a torna 
compatível com um modelo de inteligibilidade haurido na Física Mecânica: o homem, como matéria em movimento, esforça-se, como todos os outros corpos, para a autoconservação; se encontra outros homens, da igual tendência para a autoconservação resulta o impedimento recíproco e, deste, o conflito, conflito que Hobbes define como "estado de guerra" de todos contra todos e que afirma ser a condição prevalecente no Estado de Natureza, anterior ao surgimento do Estado Civil. No entanto, o essencial da transposição do modelo analítico e linear nem está nesta imagem materialista do homem, que não passará para outros pensadores posteriores. O que é verdadeiramente decisivo é que, na visão de Hobbes, o fenómeno político, aquilo que ele denomina como o "Commonwealth", seja descrito à luz da dupla tese da pré-existência das partes relativamente ao todo e da redutibilidade das propriedades do todo às propriedades das partes. Em primeiro lugar, Hobbes decompõe atomisticamente a comunidade política em elementos simples, os indivíduos, e admite que estes podem ser considerados por si próprios, como existindo antes e fora da sua inserção no todo - trata-se do Estado de Natureza, como estado pré-político da vida dos homens, de que Hobbes e tantos outros teóricos políticos modernos, como Locke ou Rousseau, falarão amplamente. Em segundo lugar, a comunidade política e o poder civil são explicados como resultados de um certo arranjo particular entre esses indivíduos que existem não só independentemente como também anteriormente à comunidade e ao poder do Estado - trata-se do Contrato, "convenant", em que Hobbes e boa parte dos teóricos políticos modernos verão a origem do Estado, fazendo-o assentar num acto deliberado de instituição por parte de indivíduos em estado pré-político. Uma vez realizado este arranjo particular entre os indivíduos, diz Hobbes, eis que "a multidão, assim unida em uma pessoa, é designada um Commonwealth, em Latim, civitas".

Esta visão do fenómeno Político padece, a meu ver, de duas deficiências de base. Elas têm que ver com uma certa feição construtivista do pensamento político moderno, com o facto de ele, guiado pela visão analítica e linear, haurida nas novas ciências da natureza, se ir perder em hipóteses arbitrárias sobre a génese da comunidade política que lhe impedem o acesso às evidências do fenómeno político enquanto tal.

Primeiro que tudo, com a figura do contrato e a ideia do Estado por instituição, surge uma ficção que não parará de fazer o seu caminho no pensamento político 
moderno: a da origem, e da origem popular daquilo a que chamamos o "poder civil"; por outras palavras, a ficção de que o poder civil tem uma génese, e de que essa génese pode ser encontrada numa decisão tomada pelos indivíduos, que por essa via se constituiriam como um povo. O pensamento político anterior havia vivido largamente na ficção da origem divina do poder civil. Filmer afirmá-la-á ainda em pleno século xvi. O pensamento político que se inicia em Hobbes substituirá, porém, relativamente ao facto do poder, a ficção da origem divina pela ficção da instituição popular. Isto não significa que o pensamento moderno tenha, por fim, divisado a "verdadeira" origem "democrática" do poder político. Significa, apenas, que substituiu a ficção da outorga transcendente pela ficção da génese imanente, por força do seu modo analítico e linear de inteligibilidade, para o qual as propriedades de topo de um sistema têm de ter a sua origem num arranjo particular dos elementos que o compõem. No entanto, esta génese do poder civil a partir de um contrato livre entre os indivíduos é simplesmente uma construção - mais que isso: uma quimera - que encobre a circunstância de o poder ser algo que se dá como um facto absolutamente primitivo, para lá do qual não é possível remontar, a não ser, precisamente, por meio da construção de hipóteses sem nenhuma relação com as evidências do fenómeno político enquanto tal (voltaremos a isto). Pouco importa que certos autores tenham entendido esta génese da comunidade política a partir de um contrato como uma simples "ideia reguladora", que nada diria sobre o modo como a comunidade historicamente se originara, mas apenas sobre o modo como ela "deveria ser". Esta subtileza inane, que se encontra em Kant, por exemplo, não altera em nada o fundo da questão, ou seja, nada altera quanto à pretensão de recuar mais atrás do facto do poder em direção a uma sua instituição original (agora, sob a forma de uma origem imanente), seja ela entendida como uma instituição real ou como um simples modo de pensar.

A segunda insuficiência - conjugada, aliás, com a primeira - é aquilo a que chamarei a hipertrofia do "princípio de representatividade", usando este conceito num sentido algo diferente do habitual, a saber, no sentido em que a representatividade não será, agora, uma função entre outras dentro de um sistema político, mas passará a caracterizar (diria: mascarar) a própria essência do político como tal. A essência do político está dada na ideia - e, posteriormente, nos mecanismos institucionais - de representação. 
O que isto significa será visível se regressarmos às ficções fundadoras do pensamento político moderno. Na medida em que a ficção contratualista moderna (ou qualquer variante crítica que assuma, porém, a tese da origem popular do poder) põe na decisão dos indivíduos em estado pré-político (real ou suposto) a génese do poder civil, este último ficará determinado pela propriedade de representar, nos atos da sua vontade, a totalidade dos indivíduos que lhe deram origem. O poder civil exerce-se, portanto, "por todos", "para todos" e "em nome" de todos, porque de todos "provém". A essência do poder político é, assim, a de "representar", neste sentido plurifacetado. Hobbes dizia, justamente, que quem detinha o mando era ator de atos de que a inteira multidão era a autora. E isto não porque o soberano hobbesiano formasse a sua decisão consultando, sob qualquer forma, a multidão dos indivíduos, mas porque, por essência, um acto do soberano seria um acto representativo, na medida em que o poder que nele se exerceria seria o da própria multidão.

Há pelo menos três aceções relevantes deste conceito de representação, assim transportado para a essência do político. A primeira é o sentido cognitivo: as decisões do poder civil são os atos por meio das quais o corpo político a si próprio se conhece (a si próprio se "representa", ou seja, se eleva à autoconsciência e ao autoconhecimento) - elas ao mesmo tempo determinam e dão a conhecer a sua vontade. A segunda aceção é o sentido constitutivo: as decisões do poder civil representam o corpo político na medida em que são os actos por meio dos quais o corpo político se constitui, e o que aparece como corpo político é a própria multidão de indivíduos, de tal modo que as decisões do poder civil são ("representam"), num sentido eminente, as decisões da própria multidão, mesmo aí onde não exista ainda qualquer mecanismo de integração da vontade de cada indivíduo numa única vontade geral. A terceira, por fim, é o sentido institucional: as decisões do poder civil tenderão a estar escoradas em mecanismos formais de auscultação (ou mesmo de "representação", justamente no sentido vulgar, em que algo que está no lugar de outra coisa) da opinião de todos (ou apenas de alguns) e de conversão da sua opinião numa vontade geral única, que vincule a totalidade dos membros do corpo político. Assim, as deliberações políticas são uma representação do corpo político no sentido de o conhecerem; elas representam o corpo político no sentido de lhe darem consistência; finalmente, elas representam o corpo político no sentido de serem 
tomadas em seu nome. Tais são os sentidos cognitivo, constitutivo e institucional da ideia de representação como essência do político. Mesmo aí onde não haja representação segundo o modelo "democrático" moderno da eleição, por sufrágio direto e universal, de uma assembleia legislativa, há-a neste sentido mais profundo de a própria essência do político estar pensada como representação. Mesmo o poder absoluto do monarca hobbesaino é um poder erigido sobre e legitimado pela ideia de representação.

Esta determinação do ato político pela representatividade passou para todo o pensamento político moderno e chegou até hoje. Na sua forma amadurecida, o facto de os indivíduos estarem efetivamente envolvidos como autores - diretos ou indiretos - dos atos do poder civil passou a valer como condição da sua própria legitimidade e do seu poder de obrigar. O princípio da representatividade como essência do ato político evoluiu desde a representação quase por antonomásia da comunidade política como um todo (o autor) na pessoa do soberano (o ator), à maneira de Hobbes, até conceções como as de Rousseau e de Kant, segundo as quais, para os indivíduos, a sua condição de membros passivos do Estado, ou súbditos, teria de estar suportada pela sua condição de membros ativos do Estado, ou cidadãos, de tal modo que, na obrigação política, cada indivíduo, submetendo-se ao poder civil, não se submeteria senão à lei que se dera a si próprio. A obediência ao poder civil deixou de estar vinculada apenas à ficção do contrato original (uma obediência que passaria, misteriosamente, de geração em geração), para passar a depender da condição suplementar de uma participação (direta ou por deputação) na formação das decisões coletivas. No pensamento político do século xix, este princípio de representatividade assumirá a forma de um poder legislativo instituído numa assembleia que possa efetivamente falar em nome dos cidadãos. A convicção de base para esta forma institucional do princípio da representatividade será que, aí onde o poder civil não delibera segundo uma modalidade de efetiva formação plural da vontade, de tal modo que esta seja efetivamente representativa de todos (de todos os que são membros ativos do Estado, cidadãos), ele ultrapassa também os limites do seu exercício legítimo. A ideia é, pois, a de que toda decisão legítima se enraíza na representação, que a decisão deve estar, senão escorada, pelo menos limitada por instituições representativas - a ideia que passou a dominar a conceção moderna do poder civil é, pois, a de que a representação é a essência do político, e que a forma 
institucional plena da representação é a assembleia legislativa. Mais fundamental que a decisão é a representação. No limite, a decisão política que se quer legítima provirá da própria instituição que se constitui em torno da função representativa, agora alçada a essência do político.

4. O pensamento político moderno entendeu a decisão política como representação, no triplo sentido cognitivo, constitutivo e institucional. Esta "evidência" é, contudo, o resultado de uma construção. Ela escora-se na ficção de um estado pré-político dos indivíduos e de uma geração do corpo político através de um ato deliberado de instituição, em que todos tomam parte. Esta ficção dúplice de um "antes" do corpo político e de um momento originário de "instituição" - que responde à questão de saber por que razão os indivíduos estão vinculados às decisões do poder civil - resulta, como foi dito, do modelo analítico e linear que o pensamento político na modernidade tomou de empréstimo às ciências da Natureza.

Contudo, quando olhamos o fenómeno político sem o fazer regredir a uma origem construída, ficcional, o que aparece como seu elemento nuclear não é a representação, mas o dado nu da decisão com valência coletiva, acerca da qual o princípio da representação é já uma interpretação - e uma forma, entre outras possíveis, de operacionalização -, precisamente a interpretação que se tornou dominante entre os modernos. E isto porque o fenómeno fundamental da comunidade política não é a multidão dos indivíduos abstratos, tão-pouco a instituição do Estado pela multidão - é antes a existência dos indivíduos no seio do corpo político, e a existência do corpo político em decisões de valência coletiva, que são as formas concretas da sua ação. O que a teoria política moderna designa como "poder civil", para o qual pretendeu ficcionar uma origem que era ao mesmo tempo um modo de legitimação, não é, na realidade, algo que tenha uma génese, mas é, pelo contrário, um dado primitivo, tão originário como os grupos humanos. Na verdade, aí onde há um grupo e uma vida coletiva, há também uma instância de tomada de decisão e de regulação global do comportamento coletivo quer define o grupo na sua vida "política". Não há verdadeiramente uma origem para isso, que doravante chamaremos a "instância de ducção". Diremos, antes, que só há grupo por via da instância de ducção que possibilita um 
comportamento coletivo, e que essa instância não é ninguém, mas uma estrutura que emerge no e com o grupo, sem que para ela um procedimento instaurador possa ser encontrado. Há, de facto, procedimentos que definem e regulam a configuração dessa instância de ducção, nomeadamente através de instituições, de cargos e funções, mas os procedimentos definidores não criam essa instância - pelo contrário, pressupõe-na, ou seja, pressupõem que um grupo, ou uma colectividade, só se comporta e aprende como tal por referência a uma instância, nela emergente, de ducção.

Mudemos, então, de terminologia. Abandonemos, desde logo, a metáfora moderna do "corpo político", metáfora tão próxima do paradigma mecânico da Física, proximidade que nada tem de acidental, aliás, como sugerimos atrás. Falemos do que é dado tal como é dado - ao invés de "corpo político", falemos de grupo, enquanto unidade da vida coletiva de uma multiplicidade de indivíduos que não lhe pré-existem e que jamais subsistem no grupo como meros átomos isolada e abstratamente tomados. Consideremos o grupo como fenómeno fundamental. Ele pode conter já outros grupos, ou congregar-se com outros num grupo mais complexo, mas não se decompõe em indivíduos, que são, justamente, o seu oposto, tal como, mesmo do lado do pensamento geométrico, um espaço não se decompõe em (nem se compõe de) pontos. É certo que podemos sempre retirar cada indivíduo da sua pertença a um grupo e considerá-lo isoladamente. Mas, com essa operação, retiramos também o fenómeno político. Do mesmo modo que não podemos, inversamente, recuperar o fenómeno político conjugando ou adicionando simplesmente tais indivíduos isoladamente considerados. O grupo é o sujeito da vida política. E o indivíduo é uma abstracção-limite do pensamento político. O que se pode dizer dele, qua tale, é que é a forma do apolítico por excelência.

Abandonemos, de seguida, a metáfora do "poder". Um grupo não é uma soma de comportamentos individuais (ou uma sua resultante, como no paralelogramo das forças), mas um comportamento coletivo. Onde há um grupo, surge, nele e com ele, o que chamei uma instância de ducção. Entendo por isso que o comportamento do grupo não resulta dos comportamentos isolados dos indivíduos, mas que é o comportamento dos indivíduos que se determina como comportamento grupal por referência de todos eles a uma instância decisória com valência coletiva. Esta instância não é ninguém, e também não pode 
ser descrita como um "poder" de condicionar ou coagir o comportamento dos indivíduos. O facto primitivo é que, no seio de um grupo, há linhas de ducção coletiva pelas quais os indivíduos ajustam o seu comportamento num comportamento global coordenado, sem que isso tome a forma de uma instituição deliberada ou de um processo coercivo de uniformização. Simplesmente, um grupo é isso mesmo: um comportamento coletivo induzido por mecanismos que são imanentes ao próprio grupo. Vemos isso em casos simples de etologia animal: um cardume tem um comportamento coletivo na sua trajetória, do mesmo modo que uma manada de herbívoros adquire uma direção coletiva em situações de migração ou de fuga a predadores. Nuns casos, o grupo é "monocéfalo", por assim dizer: todos os membros seguem a decisão de um outro; noutros casos, o grupo é "policéfalo", já que o comportamento coletivo deriva de decisões de cada elemento do grupo relativamente aos mais próximos, como, por exemplo, a manutenção da mesma distância relativamente aos elementos contíguos. Não importa as formas de ajustamento do comportamento grupal. O que importa é que o grupo tem um comportamento coletivo determinado por uma instância de ducção. O elemento essencial nesta instância é o par decisão-seguimento. Nos grupos humanos, infinitamente mais complexos que o movimento coletivo de certos grupos animais, o elemento diferencial é justamente o facto de a forma de ducção e de o processo de decisão-seguimento não estarem já determinados no património biológico da espécie, mas serem objeto de procedimentos de fixação e de preservação (ou de alteração). É essa variabilidade de formas de fixação-preservação-alteração que os conceitos de instituição e de deliberação política recobrem. Nos grupos humanos complexos (mas não em pequenos grupos de indivíduos, onde espontaneamente alguém acaba por ocupar a posição de guia, de decisor que determina os comportamentos grupais), há, de facto, uma instituição e uma escolha. A ilusão moderna é que os indivíduos começavam por criar deliberadamente o próprio "poder", para depois - ou em simultâneo - decidirem sobre a sua forma. No entanto, se dissiparmos esta ilusão, veremos que o "poder" estava desde sempre já lá, como facto primitivo, para que se pudesse decidir sobre quem o incarnaria e sobre os modos e processos da decisão coletiva: ele, o impropriamente chamado "poder", é justamente a instância de ducção, imanente a qualquer grupo e tão originária quanto ele. 
Abandonemos, por fim, a metáfora da "força". O "poder" não é uma "força" de coerção, sempre maior que a força de resistência de cada indivíduo, por se tratar da força unida da comunidade política como um todo. Digamos de outro modo: o princípio de ducção, imanente ao grupo, induz linhas comportamento que são o próprio grupo em acto, de tal modo que, para cada indivíduo, opor-lhes resistência representa um movimento para fora do espaço do grupo, ou seja, a sua desagregação. O "cimento" que une cada indivíduo ao grupo é o grupo mesmo. Não há aí nada para representar como uma força, por semelhança, digamos, com o modo como uma massa maior constrange o movimento retilíneo de outra massa menor e a coage a descrever uma trajetória em seu redor. Simplesmente, cada indivíduo é um membro do grupo na exata medida em que está envolvido no processo de decisão-seguimento e integra, com a sua atuação, a vida do próprio grupo. Se entendermos o grupo como o sujeito primário da vida política, a questão fundamental não é a da "força" que coage ou que "gruda" os indivíduos ao grupo, mas a de saber como as decisões com valência colectiva são tomadas e (eficazmente) propagadas no seio do próprio grupo, de modo a que este tenha um comportamento unitário, na tripla relação do grupo com os seus membros, dos seus membros entre si e do próprio grupo com outros grupos diferentes.

Efetuada esta mudança de termos, que é também o esboço de uma mudança de perceção do fenómeno político, façamos, enfim, duas precisões importantes.

A primeira é que isto, que foi dito, representa como que uma determinação genérica da comunidade política, pois o que acaba de ser destacado é válido para não importa que grupos: em todos eles, emerge uma instância de ducção, com ela, uma capacidade de decisão e uma propagação coletiva da decisão, que determina um comportamento global (diferenciado nas três relações fundamentais). A diferença específica para a comunidade política está em que um grupo que seja uma comunidade política projeta com exclusividade as suas decisões sobre um espaço geográfico (um "território"), possui, ainda, mecanismos de regulação da ordem interna e de proteção externa, e está, por fim, em relação (tensional ou não) com outros grupos semelhantes.

A segunda precisão é que a apresentação do conceito de indivíduo atomicamente considerado como uma categoria não-política, bem como a tese, com ela conjugada, de que o fenómeno político começa não nos indivíduos mas no 
grupo e na sua dinâmica coletiva de decisão, não sugere uma desvalorização da categoria do indivíduo e não propõe um apagamento da individualidade no seio da vida do grupo. A crítica da ficção demoliberal não se faz, aqui, em prol de uma visão totalizadora da vida política. Bem pelo contrário. Ela tem o sentido de uma limitação do fenómeno político. Este diz respeito apenas a certas dimensões da totalidade da vida humana individual e social, mormente àqueles aspetos que tangem à regulação da vida coletiva de uma comunidade, e não se expande para as formas particulares de organização da vida individual, nomeadamente a pertença a grupos diferenciados, pela qual os indivíduos desenvolvem concretamente a sua individualidade. Se há aí uma crítica, ela tem antes que ver com a abstração demoliberal do indivíduo enquanto unidade de base da vida política e sujeito de direitos que seriam não só anteriores à sua inserção em grupos, como à sua pertença a uma comunidade política. Por mais que escavemos e desagreguemos a vida concreta, nunca encontraremos o indivíduo abstracta e atomicamente considerado, em privação de todas as suas relações. Daí que a ideia moderna de auscultar o indivíduo e fazê-lo, nessa pobreza exangue, a sede de uma deliberação sobre a vida colectiva seja uma ficção sem qualquer fundamento real. O indivíduo passou-se sempre para a vida no seio de um grupo, e a vida individual é uma vida multifacetada em vários grupos e num grupo político global. Arrancá-lo dessa teia concreta de relações, auscultar o indivíduo ou o cidadão em abstrato, pedir-lhe que cuide do bem comum e seja participe da vontade geral, é esquecer que cada indivíduo existe na comunidade política não como sujeito isolado, mas como participante em vários grupos, onde ele é, em simultâneo, muitas e variadas coisas, tem múltiplas fidelidades, e só nessa forma real da sua existência pode ser um membro da comunidade política.

5. A minha tese é, pois, que a teoria política moderna projetou sobre o fenómeno político um modelo analítico e linear haurido na ciência da natureza. Isso conduziu à ideia de uma génese da comunidade política a partir de uma livre decisão de indivíduos em estado pré-político e conduziu, mais além, à perceção do fenómeno político como representação. Se, porém, eliminadas as ficções construtivistas, olharmos o fenómeno político tal como se mostra e segundo o seu sentido imanente, verificaremos que o seu lugar primitivo é o grupo, e que 
a sua forma de aparição é a decisão coletiva, ou melhor, não tanto o decidir coletivamente, de modo direto ou indireto (isso é já a interpretação moderna do poder como representação), mas a decisão com valência coletiva a partir de uma instância de ducção que é imanente ao próprio grupo.

A esta luz, olhemos, para terminar, a crise hodierna da nossa vida coletiva. Esta está em processo acelerado de desagregação. O descrédito da vida pública e dos agentes políticos não poderia ser mais patente, nem mais justificado. A experiência democrática demoliberal da Primeira República precisou apenas de 15 anos para se afundar na desordem e para fazer o povo detestar a democracia parlamentar. O sistema político-constitucional que tão inabilmente construímos em 1975 precisou de 30 anos para entrar em colapso e perda abrupta de legitimidade. Apesar de ter o dobro da longevidade, o seu mérito não é grande, pois as mesmas taras deploráveis - e outras mais graves ainda - emergem com particular acuidade. Não tardará o dia em que, uma vez mais, o povo grite na rua a sua aversão à democracia.

O problema não está, porém, na democracia (o que dissemos sobre o grupo e a emergência da instância de ducção é um reconhecimento de que todo o poder se exerce pelo povo e ao povo pertence). O problema está em que o nosso sistema político-constitucional se construiu por uma hipertrofia da ideia de representação e que o enquadramento da intervenção pública foi confiado, em regime de quase-exclusividade, aos partidos políticos silenciando os grupos concretos da sociedade. Aí vejo a causa permanente dessas disfunções do nosso sistema político que hoje vêm à luz do dia e fazem perigar a democracia.

Desde logo, o princípio de representação

- Bloqueou a eficácia da decisão política, fazendo as funções executivas estarem sistematicamente dependentes de validações em assembleias;

- Hipertrofiou o sistema político, fazendo pulular por todo lado assembleias supostamente "representativas", formadas por lista (desde a junta de freguesia até a assembleia legislativa, passando por um, nunca felizmente realizado, nível de poder intermédio, dito "regional"), de tal modo que o sistema de decisão não só perdeu em eficácia, como cresceu desmesuradamente em número de atores, todos eles passíveis de múltiplas pressões e influências, que retiram legitimidade às próprias deliberações; 
- Desfigurou a própria forma fundamental de qualquer sistema político, suspenso num poder decisório supremo como expressão última da vida coletiva, ao diminuir, por sucessivas revisões constitucionais, os poderes do Presidente da República, em prol de uma assembleia legislativa multitudinária, pletórica e tonitruante.

- $\quad$ Liquidou, por fim, a própria margem de autonomia dos deputados, ao fazer o sistema eleitoral basear-se em listas partidárias, sem representação uninominal por círculos, volvendo os deputados em funcionários servis, verdadeiros assalariados dos partidos, sem liberdade nem capacidade de intervenção crítica.

Um sistema destes não precisa de reforma. Precisa de refundação. E de uma refundação haurida no núcleo fundamental do fenómeno político, ou seja, no princípio da decisão, liberada das armadilhas "representativas" que atualmente o manietam. Isso implica a diminuição drástica das assembleias, bem como da frequência das suas convocações, e a clara assunção do comando, de modo a ser visível não só quem decide, mas quem tem a responsabilidade das decisões. Um regime político assente na decisão não é incompatível com a democracia, porque a democracia não é a representação. É esse o equívoco que alimenta o sistema atual e nos põe a todos, coletivamente, no falso dilema de ter de escolher ou isto ou a subversão autoritária da democracia.

E seria aconselhável que o povo tomasse, por fim, seriamente nas suas mãos a responsabilidade pelo seu autogoverno, antes que o descrédito do sistema político-constitucional atual se transforme em ódio à democracia e de novo mergulhemos nos dias sombrios de um regime ditatorial que nos faça entrar numa menoridade cívica de que, por inação, todos nós, afinal, seremos merecedores. 
(Página deixada propositadamente em branco) 
Crise nos e dos Media 
(Página deixada propositadamente em branco) 
António Fidalgo

UBI

\section{Elegias da Cultura NA ERA DA INTERnet}

1. Desde sempre, ou pelo menos desde o Fedro de Platão, a emergência de um novo meio de comunicação deu azo a ditirambos e a elegias; uns vendo no novo meio a aurora de uma época mais capaz e mais inclusiva, outros achando que o novo meio representava a morte da cultura, preterindo o verdadeiro saber em favor de um conhecimento aparente, que se ficava pela rama. Foi assim com o surgimento da escrita, com a invenção da imprensa, com os meios eletrónicos de comunicação e hoje com a Internet. Enquanto muitos veem na Internet um poderoso meio de informação e de comunicação, com possibilidades quase ilimitadas de promover o saber e a cultura, outros acham que a Internet é um meio de estupidificação geral. O texto de Nicholas Carr "Is Google making us stupid?", publicado na revista Atlantic Monthly de julho de 2008 teve o mérito de enunciar o que era uma vaga sensação sentida por muitos, sobretudo pelos que faziam um uso diário da Internet, de que o acesso fácil e ilimitado (everywhere anytime) à informação não tinha correspondência numa melhor formação cultural e humanística. Com efeito, houve a perceção, nomeadamente por parte de docentes universitários, primeiro, que os jovens que nasceram já na era dos meios digitais, designados por digital natives, chegavam à universidade com lacunas graves na formação escolar e, em segundo lugar, que a própria forma de pensar estava sofrendo alterações profundas.

Nesse artigo, Nicholas Carr começa por constatar que nos últimos anos a sua maneira de pensar se modificara e que isso se notava desde logo na capacidade de leitura. Antes era-lhe muito fácil concentrar-se na leitura de um artigo ou de um livro e passar horas a fio seguindo uma longa narrativa ou as voltas intrincadas de uma linha de raciocínio. Agora, pelo contrário, verificava que a atenção se 
desviava ao fim de duas ou três páginas, que começava a ficar nervoso, impaciente, a perder o fio à meada, e à procura de qualquer outra coisa para fazer. E a explicação que encontra e aponta para esta alteração é a Internet. É que durante mais de uma década estivera online, navegando e fazendo buscas pelas grandes bases de dados online. Para um escritor como ele a Internet era uma dávida dos céus. Pesquisas que antes demoravam dias em canseiras por arquivos e bibliotecas, agora poderiam ser feitas comodamente em casa num computador ligado à Internet, levando minutos a obter as informações desejadas mediante algumas buscas efetuadas no Google. Além disso, a Internet oferecia-lhe tudo em um, comunicação por email, informação noticiosa, leituras de todo o tipo em múltiplos e diversos blogues, audição de podcasts e visionamento de vídeos. Era o meio universal, a bem dizer perfeito, que dispensava todos os outros. Só que tudo isto oferecido a um custo pesado: a perda das capacidades de concentração e de contemplação. Os meios não apenas passam a mensagem, os múltiplos e variados conteúdos, que alimentam o pensamento, eles alteram também o modo de pensar, de acordo com a doutrina de McLuhan.

Ler na Internet não é a mesma coisa que ler no velho papel. Afastando-se do meio impresso as pessoas deixaram de ler livros, e habituaram-se a passar os olhos (a fazer um scannning) pelos textos que passam continuamente pelos ecrãs dos computadores. É possível que hoje, na era da Internet, até se leia mais do que antes, na era da televisão, e isso graças a emails, a mensagens SMS, e à ubiquidade dos textos em milhares de blogues e de sítios na Internet. O problema é que é um outro tipo de leitura. A imediatez e a eficiência típicos da Internet debilitam a nossa capacidade de leitura lenta e atenta. Online tornamo-nos mais descodificadores de informação escrita do que verdadeiros leitores, prontos a imergir no texto e a seguir as múltiplas ramificações de pensamento a que nos leva a leitura.

O ponto crucial do artigo de Nicholas Carr é que o cérebro não é algo acabado, mas um órgão altamente maleável que se vai adaptando às realidades e desafios que o envolvem e que a Internet está de facto a alterar o modo de funcionamento do cérebro. É este ponto que é desenvolvido extensivamente no livro The Shallows: What the Internet is Doing to our Brains, publicado por Carr em 2010. Com a disseminação da Internet é a atividade intelectual do cérebro que se altera, ou seja os modos de como percecionamos e pensamos. 
Em vez de mergulhar nas águas profundas do conhecimento que os livros impressos nos ofereciam, ficaremos pelas águas baixas e salobras (the shallows) da informação online.

O tenor das posições de Nicolas Carr ecoa as preocupações de autores anteriores, como Neil Postman, We are amusing ourselves to death de 1986, e de Sven Birkerts, The Gutenberg Elegies de 1994. Na linha do pensamento de Marshall McLuhan de que os meios não se limitam a passar informação, mas que a condicionam fortemente, tanto dos lados dos emissores como dos recetores, estes autores consideram que a introdução dos meios eletrónicos e digitais de comunicação constituem uma rutura significativa nos processos pessoais e sociais de aprendizagem e de aculturação.

O livro de Postman, anterior à vulgarização da Internet graças à Web, é uma crítica contundente à televisão. A televisão não é um meio de informação, nem um meio de educação, mas, no fundo, um meio de entretenimento que converte tudo em diversão: a informação transforma-se em info-diversão (infotainment) e a educação em edu-diversão (edutainment). Na televisão sobrevivem apenas os programas que conseguem audiências e estas só se mantém se houver, de um modo ou de outro, entretenimento: sensacionalismo, curiosidade doentia, distração. Tudo o resto passa à categoria de aborrecimento. É da própria essência do meio televisivo entreter. Querer que sirva para outros fins, nomeadamente informativos e educativos, é não entender a natureza do meio audiovisual, que não é de todo apropriada a uma descrição e explanação conceptual. A televisão não é feita para discursos, nem para palavras, mas sim para imagens e telenovelas.

Kant distinguia conceitos e intuições pelo facto de os primeiros serem representações universais, válidos para qualquer objeto, facto ou circunstância, enquanto as intuições são individuais, cingidas ao aqui e agora da experiência. Ora as palavras são conceitos e os sons e as imagens são intuições, pelo que a natureza audiovisual e eo ipso intuitiva da televisão não se compagina com discursos ou raciocínios longos.

Ao mesmo tempo que crítica à televisão, o livro de Postman é também uma elegia da mente tipográfica, das capacidades perdidas de concentração e de raciocínio que caracterizavam os discursos públicos no século XIX. Se antes do advento das tecnologias de imagem, cinema e televisão, oradores e ouvintes eram capazes de aguentar horas seguidas os múltiplos debates que marcavam 
as campanhas políticas norte-americanas, era simplesmente porque tinham sido forjados pela disciplina linear da palavra impressa. O livro treinava nos leitores a concentração e a atenção prolongada, ao passo que a televisão habitua os espectadores à distração e dispersão contínua.

Os livros de Birkerts e de Carr partem de uma verificação comum, e que certamente também é nossa. Os jovens deixaram de apreciar literatura e não leem livros. Birkerts conta como lecionando no outono de 1992 um curso intitulado "The American Short Story" a alunos de graduação, se deparou com uma indiferença estranha. A turma era composta de alunos inteligentes, diligentes, mas os textos selecionados de textos de Washington Irving, Hawthorne, Poe, James e Jewett, não suscitaram de modo algum o suposto fascínio ou sequer o interesse dos estudantes. Nem o vocabulário, nem a sintaxe, nem o enredo constituíam dificuldades. Entendiam tudo, só que o problema era "o todo" (the whole thing). Escapava-lhes o sentido das novelas, como se pertencessem a um outro mundo. O problema não era este ou aquele autor, o problema residia no facto de "a experiência coletiva dos estudantes, nascidos na primeira metade da década de 70, ter feito de uma grande parte da nossa herança cultural algo completamente estranho para eles." ${ }^{\circ 0}$ O que os estudantes não entendiam era o que estava debaixo do vocabulário e da sintaxe, e isso era "todo um sistema de crenças, valores e aspirações culturais" 91.

Os textos eram fruto de um mundo e de uma época a que os meios eletrónicos de comunicação puseram fim. A incompreensão dos alunos, ou melhor, o desinteresse e fastio que sentiam por aquelas histórias, não resultava de uma qualquer circunstância particular, mas sim de uma mudança sistémica de atitudes e de assunções, que Birkerts situa algures na década de 50 do século passado, quando a televisão entrou nos lares americanos e as pessoas começaram a viver em dois mundos paralelos, um em que viviam e outro em que podiam entrar sempre que buscavam um intervalo ou uma fuga da vida que levavam. ${ }^{92}$

Os livros pertencem ainda, de algum modo, ao mundo que o homem habitou ao longo de milénios, em que o espaço e o tempo delimitavam a existência individual e constituíam poderosas barreiras à comunicação. A imediatez e a

\footnotetext{
90 Birkerts, 2006, p. 19.

91 ibidem.

92 idem, p. 214.
} 
omnipresença das comunicações eletrónicas vieram alterar profundamente a maneira de estar e de viver dos indivíduos e das comunidades. Birkerts escreve que hoje em dia haverá muitas pessoas que nunca nas suas vidas passarão pela experiência de estar num local isolado, no meio de árvores e de pedras, a mais da distância do grito de outra pessoa, sem qualquer dispositivo de telecomunicação, forçadas à lenta e dura passagem do tempo, experiência essa que era a norma na vida das pessoas em épocas passadas. As formas de viver que regularam o dia a dia dos indivíduos e se tornaram bens culturais passados de geração em geração tornaram-se, de repente, em grande medida irrelevantes. Hoje estamos permanentemente conectados, graças aos novos meios, com mais e mais pessoas, fisicamente ausentes, enquanto vamos diminuindo as relações presenciais, face a face. ${ }^{93}$

Imerso num livro, o leitor encontra-se só, envolto num espaço e num tempo que é só dele. É que a leitura atenta (deep reading) de um livro se distingue em muito da comunicação eletrónica. A ordem tipográfica é linear, obedece às regras da sintaxe, que estabelece as coordenadas da linguagem com sentido. A comunicação impressa exige uma participação ativa por parte do leitor, nomeadamente uma atenção dedicada, pois que ler é um ato de tradução de símbolos e de interpretação. Por outro lado, a tipografia determina um eixo temporal: a ordem de leitura, ao longo das linhas, de cima para baixo, e o voltar das páginas, constitui um movimento contínuo em frente, servindo os conteúdos lidos previamente de fundamento aos conteúdos posteriores. Acrescente-se que os materiais impressos são extáticos, é o leitor que avança e não o livro. O ritmo de avanço é lento. Ou seja, as características físicas do livro estão de acordo com o sentido tradicional de história.94

A ordem eletrónica é, em muitos aspetos, o oposto. A informação não passa de um setor privado para outro, mas por uma rede pública, onde passam outras informações no âmbito de um circuito de múltiplas conexões. Por outro lado, a comunicação eletrónica é passiva, no caso da televisão, ou interativa, no caso do computador. Os conteúdos são efémeros; mudam-se e apagam-se com o pressionar de um botão ou de uma tecla. O ritmo é rápido, caracterizado por

\footnotetext{
93 idem, p. 214-215.

94 idem, 122.
} 
saltos e interrupções, e o movimento procede lateralmente por associações, mais do que por uma cumulação vertical.

As consequências da mudança de como lemos são vastas e profundas. Desde logo assistimos a uma erosão da linguagem. Os meios eletrónicos de comunicação exigem uma enorme simplificação da linguagem, designadamente da sintaxe e da semântica. As complexidades características da escrita tipográfica dão lugar a uma linguagem telegráfica. Há um empobrecimento vocabular e uma platitude sintática. É o triunfo total da denotação sobre a conotação. Não há mais lugar aos duplos sentidos, à ambiguidade, ao paradoxo, à ironia, ao humor, à subtileza. Exige-se mesmo que o que é complexo e longo seja transposto para uma formulação simples e breve, inevitavelmente à custa de perdas importantes de significado. É claro que a literatura é uma das vítimas desta erosão linguística. Não é preciso que seja um texto de um dos clássicos, por exemplo Francisco Manuel de Melo, Rodrigues Lobo, Bernardes ou Vieira, mesmo um texto literário contemporâneo é incompreensível a muitos dos estudantes universitários.

Outra das consequências da leitura eletrónica é o esbatimento da perspetiva histórica. Um livro não é apenas o seu conteúdo, é também um objeto físico com múltiplas indicações sobre a sua origem e o seu passado. O tipo de encadernação, o uso que denota, se muito ou pouco lido, sublinhado ou anotado, a localização numa biblioteca, tudo isso empresta uma profundidade histórica à leitura tipográfica, que está ausente na leitura eletrónica. Um livro insere-se sempre numa linha histórica, de uma editora, uma coleção, de um passado de pertença, que constitui um horizonte temporal inerente à sua leitura. Por sua vez, a leitura eletrónica é feita num presente perpétuo, uniforme, igual para todos os textos, que, desse modo, ficam descontextualizados.

Finalmente, Birkerts observa que no fim desta evolução deparamos com o declínio da privacidade individual. Efetivamente, há a tendência de aceitar a vida tornada cada vez mais transparente pelos meios eletrónicos. Os sistemas eletrónicos estão sempre ligados, registando continuamente os nossos passos e ações. A vida privada surge como algo opaco, pertencendo ao passado. As paredes e as portas das nossas habitações perdem relevância; o mundo entra em nossa casa pelas redes que nos mantém em permanente comunicação, comunicação essa que acaba sempre por nos expor. 
Não deixa de ser curioso que Birkerts saliente o definhamento do sentido de privacidade muito antes da Web 2.0, dos blogues e do facebook. Há jovens hoje que não entendem o que é a privacidade, que apenas distinguem o que é e o que não é segredo, sendo público tudo o que não é segredo.

Creio que este é o ponto central da elegia que Birkerts faz da cultura tipográfica. À medida que os indivíduos se ligam eletronicamente uns aos outros, à medida que todos se encontram online, há uma retração da subjetividade individual e, portanto, também uma perda da privacidade essencial à autoconsciência enquanto foro de autonomia e espontaneidade próprias. Para Birkerts a opção é clara: "o que se ganha em acesso e em eficiência é à custa da autoconsciência subjetiva". 95

A conectividade geral e permanente tem como contrapartida o sacrifício da vida própria do eu isolado. Os paladinos das novas tecnologias esquecem que os meios, além de extensões dos nossos sentidos, são também as extensões dos sentidos dos outros e que o resultado desse contacto super-mediado é a erradicação final da solidão individual que até aqui determinava os termos da existência de cada pessoa. ${ }^{96}$

Birkerts aplica a teoria benjaminiana da aura ao indivíduo. Será que cada um de nós enquanto indivíduo possui uma aura tal como os objetos de arte, uma presença única que só se manifesta no aqui e agora da localização espaciotemporal? Se sim, se efetivamente cada um de nós é dotado de uma aura própria, então o que a reprodução técnica faz às obras de arte, a depreciação da qualidade da sua existência única, no aqui e agora, ${ }^{97}$ também a miríade de meios de comunicação que envolvem o indivíduo e o conectam a outros lugares e tempos acaba por desvalorizar a presença real do indivíduo. ${ }^{98}$

Dantes, antes da introdução dos meios de comunicação, as interações humanas eram face a face, em presença. A comunicação era fundada na presença. Originariamente não havia um hiato entre a pessoa e a comunicação. Dantes, antes do megafone e do telefone, o mais longe que a voz humana ia era a distância

\footnotetext{
95 p. 220.
}

96 ibidem.

97 "Die Umstände, in die das Produkt der technischen Reproduktion des Kunstwerks gebracht werden kann, mögen im übrigen den Bestand des Kunstwerks unangetastet lassen - sie entwerten auf alle Fälle sein Hier und Jetzt."

98 p. 226. 
de um grito. O que os meios de comunicação fazem é quebrar este vínculo direto entre presença e comunicação.

Voltando à doutrina da aura, o que verificamos é que, em última instância, o efeito de todas as mediações do real, e isso significa o afastamento e a fragmentação de uma ligação direta ao mundo, pode ser comparada à depreciação da obra de arte original pela reprodução técnica. Os diversos avanços tecnológicos não só têm como contrapartida direta a diminuição da função original99 - tal como o telefone esbateu o poder e a imediatez do diálogo humano -, mas também acaba por destruir, pelo menos parte, da autoridade fundamental do próprio ser humano. Com a comunicação total e permanente o que está em jogo é nada menos que a erosão da presença humana, tanto no que respeita à autoridade do indivíduo como da própria espécie humana. ${ }^{100}$

Birkerts acaba por confessar o receio de estarmos, enquanto cultura, a tornar-nos mais superficiais (shallower), de que nos estamos a desviar da profundidade da tradição judaico-cristã que via a pessoa como mistério insondável - para nos adaptarmos a uma segurança assente nas conexões laterais. Estamos a desistir da sabedoria, que foi o objetivo último da existência humana durante milénios, para nos convertermos à fé na rede comunicacional. ${ }^{101}$

Em suma, a nossa era da comunicação total desemboca numa "morte da imaginação”, justamente por aniquilar os mundos privados e os substituir por um único mundo plano de conexões. O cenário é o de uma diminuição da cultura, a de uma erosão cultural em larga escala (a large scale leaching away). ${ }^{102}$

O posfácio de 2006 que Birkerts faz numa reedição do livro é menos negro. Passados mais de 10 anos, o autor acabou por aceitar o computador como meio de trabalho (processador de texto) e como meio de comunicação (o uso de email). A escrita do livro ocorreu no início da revolução operada pela introdução da Web gráfica em 1993 e o prefácio é já de uma data posterior à euforia das dot.com e respetivo colapso bolsista, e ao nascimento da Web 2.0 nos inícios

99 "In one of the most perceptive, if least remarked, passages in Understanding Media, McLuhan wrote that our tools end up 'numbing' whatever part of our body they 'amplify'. When we extend some part of ourselves artificially, we also distance ourselves from the amplified part and its natural functions." Nicholas Carr, The Shallows, p. 210.
100 p. 228.
101 ibidem.
102 p. 243. 
da $1^{\text {a }}$ década do novo século. As razões que aponta para a adesão às novas tecnologias são três. A primeira é que não queria gastar as energias em atitudes de recusa pouco práticas. Não valia a pena tornar-se um caso raro de rejeição de tecnologias a bem dizer aceites por toda a gente. A segunda é que desejava continuar a ter uma vida dedicada à escrita e isso impunha manter boas relações com editores, pouco dispostos a aceitar versões de obras escritas à mão ou à máquina, que obrigaria a contratar alguém para as passar a formato digital, já para não falar nos muito mais morosos processos de revisão a que as versões em formato papel obrigam (página quatro, terceiro parágrafo, segunda frase). A terceira razão, a mais importante, foi a educação de dois filhos que entretanto chegavam à adolescência. Embora seja possível criar filhos mantendo-os afastados de dispositivos eletrónicos, a cultura em que vivemos torna isso difícil, e até desagradável, mesmo que seja apenas uma simples tentativa. ${ }^{103}$

Ora aqui paira uma sombra gigante na formação da subjetividade das crianças e adolescentes, nomeadamente na construção da sua capacidade de imaginação. As tecnologias, graças a programas fascinantes e bem desenhados, oferecem um sofisticadíssimo conjunto de opções de escolha, que são superiores ao que uma imaginação individual pode alguma vez conceber. Elas integram e até convidam à participação e interatividade, e estimulam mesmo a criatividade dos utilizadores. Os novos brinquedos concebidos e realizados por equipas multidisciplinares de engenheiros, psicólogos e geeks de toda a espécie, superiorizam-se claramente às criações que brotam de um simples indivíduo. Bombardeadas continuamente por jogos e aventuras com animações fantásticas, as crianças têm dificuldades em voltar a brincar com legos ou a ler um livro de aventuras.

O ponto principal da elegia de Birkerts mantém-se. As novas tecnologias perturbam a formação da subjetividade. É que a subjetividade humana não é algo natural, mas cultural, formado ao longo de milénios, nomeadamente pela solidão, pelos obstáculos postos pela distância física e pela experiência de um tempo continuado de duração e de atenção, não entrecortado por um sem número de sinais e estímulos a dispersar-nos. O que está em causa, pois, é a subjetividade primária, fundamental, de onde nasce genuinamente a arte e o saber.

103 Aqui aplica-se às praticalidades a sentença de Thomas Kuhn sobre as revoluções científicas, de que as teorias vingam ou soçobram consoante os seus seguidores são novos ou velhos. 
Resumindo a advertência de Birkerts é que estamos a perder o mundo originário, tal como o encontrámos, e o correspondente desejo de fazer dele a nossa casa, de o conhecer a ele e aos outros que nele habitam por um presença real e imediata. E estamos a criar um mundo de procuração, um proxy, entre nós e esse mundo primeiro. Ou seja, a conectividade - e a ideologia da conectividade - elimina a oposição, a fricção, aquilo que sempre caracterizou e definiu a experiência humana como tal. Era a velha conceção da vida como luta, a repetida lembrança da mortalidade, que estava na base da tragédia, e da conceção da redenção estimulada pela tragédia. Ora a perda da oposição é a perda da polaridade e, portanto, também a perda do mistério. Não só do mistério das coisas desconhecidas, mas também o mistério do eu e do ser.

Parar um momento no tempo, sentarmo-nos num local calmo, abrir um livro, mergulhar na leitura, é entrar dentro de nós próprios e oferecer alguma resistência ao mundo da conectividade constante e ubíqua.

2. As elegias culturais de Birkerts podem ser obviamente vistas, e desvalorizadas, como uma reedição contemporânea de elegias passadas de mundos que desaparecem face às mudanças temporais. E mesmo a alegação de que hoje o caso é diferente, mais grave, de que é a própria identidade humana que está em jogo, pode ser enfrentada com o verso de Camões que "afora este mudar-se cada dia, / Outra mudança faz de mor espanto:/ Que não se muda já como soía." Podem também ser desmontadas a vários níveis, de que esse mundo natural e original nunca foi tão direto e presencial como o autor quer fazer crer, nem a teia de conexões em que hoje vivemos é o casulo artificial que nos isola desse mundo primeiro e natural.

Mas as elegias não são apenas lamento; constituem também um elemento identitário crucial em épocas de mudanças profundas. É certo que a ligação que fazem ao passado é sob o signo da perda, do que não vinga na atualidade e acaba por morrer. Contudo, o memento mori elegíaco não é saudosismo inane, antes consciência da necessidade de preservar da usura inexorável do tempo valores intemporais. Mal vai uma época onde as elegias não têm mais lugar. Com efeito, a confiança cega no futuro, na admirável capacidade da tecnologia, em que o passado é propositadamente esquecido porque escolho ao avanço 
do progresso, é não apenas temeridade juvenil, mas também aleijão intelectual grave, na medida em que oblitera a dimensão histórica da existência humana.

O sentimento da perda expresso pelas elegias, estando virado para o passado, constitui um salutar estado de cautela e de prevenção face ao presente e ao futuro. A tecnologia torna o homem qual aprendiz de feiticeiro, lidando com forças tremendas que não é capaz de controlar. Hans Jonas preconizou justamente uma ética de responsabilidade para enfrentar os desafios colocados pela tecnologia. ${ }^{104}$ Tal ética é a de uma atitude de receio e de cautela no uso e manejo das potencialidade tecnológicas, precavendo imprevisíveis, mas possíveis consequências nefastas desse uso. Jonas refere em particular a ameaça atómica de um suicídio coletivo de toda a humanidade e o risco biotecnológico da alteração da identidade humana. Porém, os riscos que o homem presentemente enfrenta não se restringem a alterações duras, tipo hardware, mas estendem-se a modificações de configuração da sua maneira de pensar e sentir, ou seja, a alterações tipo software. Birkerts chama a atenção para o risco que o uso das novas tecnologias de informação e comunicação envolve, nada menos que uma perda da subjetividade humana tal como tem sido forjada ao longo de milénios. Portanto, as suas elegias gutenberguianas não são apenas um lamento relativo a um forma específica de transmissão da cultura, são também um sério aviso ao modo como essas tecnologias são usadas no quotidiano humano, em particular na educação de crianças e jovens.

104 Hans Jonas, 1979, Das Prinzip Verantwortung: Versuch einer Ethik für die technologische Zivilisation. Frankfurt: Suhrkamp. 


\section{BIBLIOGRAFIA}

Walter Benjamin, 1939, "Das Kunstwerk im Zeitalter seiner technischen Reproduzierbarkeit". http://walterbenjamin.ominiverdi.org/wp-content/kunstwerkbenjamin.pdf

Sven Birkerts, 1994, The Gutenberg Elegies: the fate of reading in an electronic age, Boston: Faber and Faber

Nicholas Carr, 2008, "Is Google making us stupid?", publicado na revista Atlantic Monthly de Julho.

Nicholas Carr, 2010, The shallows: what the Internet is doing to our brains, New York: W.W. Norton.

Hans Jonas, 1979, Das Prinzip Verantwortung: Versuch einer Ethik für die technologische Zivilisation. Frankfurt: Suhrkamp.

Neil Postman, 1986, We are amusing ourselves to death: public discourse in the age of show business, New York: Penguin Books. 
João Pissarra Esteves

UNL

\section{A Crise da Normalização da "Crise»: OU A COMUNICAÇÃo DESCONTINUADA POR EXAUSTÃo SIMBÓLICA DA LINGUAGEM}

Este longo e um tanto pretensioso título escolhido para ilustrar aquilo que, afinal, não é nada mais do que uma breve reflexão sobre a questão da crise ou melhor, sobre apenas uma certa dimensão muito específica que esta assume nos nossos dias - exige que comecemos por uma desambiguação fundamental no que diz respeito aos propósitos deste mesmo exercício. As próximas páginas serão dedicadas a pensar a forma peculiar de uma crise que hoje se encontra amplamente reconhecida a nível da Comunicação Pública; e insistiremos mais concretamente no papel que cabe aos media a este nível, enquanto potenciais focos de crise, divididos entre uma ética e moral da comunicação, e a sua funcionalização sistémica.

Para este exercício, tomarei como ponto de partida uma caracterização geral da estrutura simbólica da comunicação pública, com atenção especial a dois vetores fundamentais: 1. a presença esmagadora que os media hoje assumem nesta mesma estrutura (a expressão "media» é aqui utilizada como termo facilitador, para designar toda essa imensa parafernália de dispositivos tecnológicos de mediação simbólica que temos à nossa disposição - para fins de comunicação pública, mas não só); 2. os problemas éticos e morais subjacentes a esta mesma estrutura (e decorrentes da situação antes referida) - questões gerais relativas a valores, normas e regras sociais, decorrentes de forma mais ou menos direta da presença dos media a nível da comunicação pública (e como resultado das características técnicas e simbólicas dos dispositivos em questão, mas também e sobretudo - do seu quadro institucional e usos sociais). 
Começando pelo mais trivial. Consideramos que a característica que melhor distingue a cultura da comunicação pública dos nossos dias será mesmo esta sua forte dependência dos media - a que se encontram associadas capacidades excecionais de produção, armazenamento e processamento de informações, possibilidades de reprodução praticamente ilimitadas (no tempo e no espaço) das formas simbólicas e, ainda, o facto de tudo isto poder hoje ser operacionalizado sem necessidade de um domínio de competências específicas especialmente complexas (refiro-me a utilizadores comuns, como é evidente).

Por outro lado, algo agora talvez já menos óbvio: o facto de todo este imenso potencial tecnológico se apresentar organizado como um aparato institucional, consubstanciado numa gigantesca rede de discursos públicos que se rege por quadros próprios e por um determinado modelo (mais ou menos formal e rígido) de estruturação das relações sociais que se processam no seu interior.

E ainda um terceiro elemento para análise, este à primeira vista mais neutral (mas talvez só aparentemente): uma nova estrutura espácio-temporal da experiência simbólica que assume em todo este quadro da comunicação pública uma importância crucial - considerando de facto como extraordinárias as possibilidades de manipulação que as formas simbólicas dos media permitem com relação aos seus diferentes contextos mais imediatos de produção e de difusão (uma manipulação no tempo e no espaço, a manipulação do tempo e do espaço).

Este conjunto de características é potencialmente indutor de efeitos de ordem ético-moral, os mais importantes dos quais poderão mesmo ser aqueles que resultam de um maior distanciamento que passa a observar-se entre os planos de produção e de receção. Em termos práticos, isto corresponde à afirmação de uma estrutura comunicacional tendencialmente assimétrica (e no que à comunicação pública em concreto diz mais diretamente respeito).

Bem sei que vivemos hoje sob o signo de uma grande promessa, anunciada pelos chamados novos media, de redenção de muitos dos males que desde sempre atingem a humanidade - e também no que diz respeito ao problema que aqui discutimos; mas não é este o momento mais apropriado para tratar tal tipo de matérias de fé (...sem qualquer menor consideração pelos crentes em geral e pelos cibercrentes muito em particular).

Especulação por especulação, sempre me parece mais sedutor (e útil) um olhar sobre o passado, ainda que um tanto romanceado, do qual se pode extrair 
uma outra imagem bastante diferente da realidade dos media nos seus primeiros momentos de existência nas sociedades modernas: quando era ainda possível estabelecer uma articulação estreita, uma continuidade mais ou menos imediata, entre a palavra falada (dos encontros sociais comuns), de um lado, e a palavra escrita (dos jornais e revistas, porventura mesmo das próprias obras literárias), de outro lado (Habermas, 1962: 42). Foi o desenvolvimento dos media que veio estabelecer um abismo entre os planos da produção e da receção do discurso - arrisco até dizer que uma tal descontinuidade tem vindo regularmente a acentuar-se, malgré os ditos novos media (mesmo descontando já todas as ambivalências que a estes são próprias). Ou seja, estamos hoje colocados perante um afastamento da experiência original de uma comunicação pública moderna, a qual começou por se afirmar primordialmente no plano da cultura e das artes, e que embora já então proporcionasse mediações simbólicas a uma escala mais ampla, não impunha ainda, propriamente, uma dissociação de lugares, de momentos e de competências entre os seus planos de produção e de recepção das mensagens - isto num momento, é verdade, em que o raio de ação das primeiras publicações impressas era ainda consideravelmente limitado.

O desenvolvimento dos media cavou um fosso entre a produção e a receção de mensagens como resultado, não apenas, do afastamento físico que passou a existir entre estes dois pólos do processo comunicacional, mas também, e mais importante ainda, tendo em consideração a incomensurabilidade de recursos e competências inerentes a cada um deles: de um lado, encontram-se o carácter institucional, o profissionalismo e a crescente especialização dos processos (técnicos) de produção e difusão de discursos e mensagens, do outro lado e em contraste, estão a informalidade e uma certa espontaneidade que continuam a imperar a nível da receção. Nestas condições, a relação de forças desequilibra-se necessariamente a favor de um dos pólos, o da produção e os seus mega complexos institucionais (as «organizações mediáticas»), fazendo com que a dinâmica geral da comunicação pública resvale cada vez mais para a órbita do cálculo, da planificação e de uma pura racionalização estratégica de recursos - das redes e fluxos de comunicações e informações, da produção e difusão de mensagens e discursos.

Não será necessário alongar-nos sobre as implicações de ordem ética e moral que resultam deste estado de coisas. Mas, por outro lado, qualquer caracterização da comunicação pública na atualidade não pode dispensar a 
perspetiva de uma outra importante dimensão da atual mediação (mediatizada): a circulação a uma escala cada vez mais generalizada da comunicação pública, consequência direta do extraordinário aparato tecnológico que os media hoje constituem, e que torna praticamente ilimitadas as possibilidades de extensão no tempo e no espaço das suas formas simbólicas.

Este aspeto possui também um recorte próprio em termos éticos e morais, em resultado das atuais possibilidades que se nos oferecem de avaliação das formas simbólicas postas em circulação: o número daqueles que podem fazer essas avaliações é potencialmente ilimitado e as oportunidades para a sua realização são também praticamente infinitas. Podemos, neste sentido, falar de um alargamento e densificação das redes de comunicação pública - e este é um domínio em que as novas tecnologias nos apresentam algo concreto de novo que não apenas quimeras ou meras profissões de fé... Algo que deve poder ser considerado de uma forma positiva, na medida em que os critérios referidos deixam em aberto a possibilidade de alcançar uma concretização com maior sucesso dos fluxos gerais da comunicação pública, em termos da sua amplitude e enraizamento sociais.

Claro que há um reverso da medalha a considerar, por assim dizer. Este potencial eminentemente libertário e emancipatório pode reverter (e reverte-se de facto com regularidade) numa certa vulnerabilidade dos media: as extraordinárias potencialidades das atuais estruturas de comunicação pública funcionam como um poderoso atrator de interesses, alguns dos quais têm conseguido impor de facto, e de forma esmagadora, o seu poder sobre os media, reduzindo estes a pouco mais que simples extensões das suas estratégias - por muito confusos (e provisórios) que sejam os resultados das pesquisas neste domínio de estudo, dos mesmos resulta com bastante clareza a confirmação desta realidade (e que, aliás, as mais recentes pesquisas sobre os chamados novos media também já vêm confirmando muito convincentemente) (p. ex., cf. Young, 1987: 121; Luke e White, 1987: 42 e sg.s; Dahlberg, 2011).

\section{Media de comunicação e media funcionais}

Do que até aqui ficou exposto, podemos concluir que a ambivalência é, pois, um traço essencial do presente quadro da comunicação pública. No que aos 
media diz respeito, esta ambivalência liga-se de modo muito estreito com as condições do seu próprio desenvolvimento no âmbito das sociedades modernas: a sua proximidade ao Estado e ao Mercado, os dois principais pólos institucionais destas mesmas sociedades.

O binómio Estado-Mercado marcou de uma forma decisiva - e continua ainda hoje a marcar - o nascimento e o desenvolvimento dos media modernos, tendo conduzido estes a uma profunda convergência quer com a economia capitalista, quer com o modelo político do Estado-Nação: a implantação, a expansão e a consolidação de qualquer um destes núcleos institucionais são indissociáveis dos media. Esta foi uma situação que se começou a definir logo a partir dos séculos XVII e XVIII, através de uma imprensa florescente por quase toda a Europa, que a seguir se estendeu de forma ainda mais decisiva com os chamados mass media (nos séculos Xix e xx) e que os atuais novos media não vieram também alterar de modo muito significativo (se é que não estarão mesmo a reforçar, perdoem-me os mais entusiastas).

É claro que as questões éticas e morais da comunicação pública não podem ser dissociadas deste importante enquadramento histórico, ou, mais propriamente, da ação bipolarizada que sobre os media modernos foi (e é) exercida tanto pelo Estado, como pelo Mercado; nos dias de hoje, porém, importa assinalar mais concretamente uma clara supremacia que o medium dinheiro vem assumindo a este nível, superando de forma inquestionável o poder político enquanto mais importante dispositivo de regulação (da comunicação pública). Estes balanços e equilíbrios, porém, devem ser vistos sempre como circunstanciais, sendo mais ou menos claro que qualquer estado de supremacia de um destes pólos institucionais não altera muito significativamente (pelo menos de uma forma positiva) a situação geral em termos éticos-morais.

Mas ainda assim, tudo isto não deixa de ser apenas uma parte da presente realidade dos media. Conjuntamente a estas duas dimensões mais marcadamente institucionais do Mercado e do Estado, há uma outra dimensão que importa equacionar; refiro-me àquilo que pode ser designado como a estrutura de uma comunicação pública propriamente dita, uma comunicação orientada por valores de liberdade e de autonomia (sobre a televisão, ver p. ex., cf. Kellner e Best, 1988: 88-89). Esta componente dos media deve ser equacionada a par, e em contraposição, à dimensão de carácter mais institucional anteriormente referida. 
A sua presença e relevância em termos axiológicos não deve, porém, ser negligenciada: mesmo em condições mais adversas, como foi o caso do período áureo dos mass media (se é que esse período já está terminado...), esta dimensão mais informal e libertária da comunicação pública nunca deixou mesmo assim de estar presente - quanto mais não seja, apenas em termos normativos e ideais, sob a forma utópica de uma aspiração ou de uma certa expectativa social. A qual permitiu, pelo menos, manter em aberto a perspetiva de uma alteração, de uma possibilidade de mudança, de inversão das situações mediáticas mais comprometedoras de um certo ideal de comunicação pública - quero acreditar que a «teologia» dos novos media, no seu melhor, se inspirará neste ideal utópico (mas em matéria de crença, como sabemos, as motivações nem sempre são perfeitamente transparentes).

Estamos, assim, perante uma outra ambivalência típica da atual estrutura dos media, que se projeta sobre a comunicação pública definindo nesta linhas de orientação díspares, linhas que entre si estabelecem fortes tensões e disputas de hegemonia. De um lado, a ação dos media funcionais (o dinheiro e o poder) e dos respetivos subsistemas sociais (a economia e o aparato político-administrativo), enquanto reguladores dos meios de comunicação, atuando à ordem de interesses particulares institucionalmente protegidos e tendo em vista a fabricação de uma pretensa vontade geral. De outro lado, está posicionada a intercompreensão linguística, cujo imperativo precede (e deve sobrepor-se a) qualquer tipo de exigências de ordem performativa (pouco importa se estas têm origem nas empresas comerciais, ou nas burocracias administrativas).

Do meu ponto de vista, este é o cerne do problema ético e moral dos media - não só no passado, mas também no presente (tanto dos «velhos media» como dos ditos "novos media", pois): uma cissura criada a nível da linguagem pública que coloca em rota de colisão - e aparta - exigências intercompreensivas, por um lado, e performatividade funcional, por outro.

Neste diagnóstico da situação - sobre os media e a comunicação pública está presumida uma prioridade simbólica no que se refere a estas realidades humanas e sociais. Ou dito de outra forma, é assumida a defesa de um paradigma comunicacional como princípio de compreensão (chave epistemológica) da realidade humana e social - no seguimento da importante intuição de George Herbert Mead (1934) quanto à forma de constituição tanto do Indivíduo (Self \& Mind) como da Sociedade. É a esta luz, portanto, e contra a tentação hoje em 
dia tão comum de considerar os processos de tecnologização em termos estritamente positivistas, que podemos afirmar a prioridade que cabe (que continua a caber) à dimensão simbólica da experiência: a supremacia dos enquadramentos de sentido de ordem cultural e moral sobre a técnica, a imperatividade de um ordenamento desta em função de valores e normas sociais legitimamente constituídas. Sendo esta, aliás, a única forma que se mostra realmente consequente para que possamos encarar as novas tecnologias como um bem em termos sociais e humanos, na medida em que deixa em aberto a possibilidade de converter toda a extraordinária performatividade técnica destes meios em algo mais substancial em termos de comunicação universal (cf. Thompson, 1992: 205-215) - ou seja, um aprofundamento da comunicação pública, tanto num plano vertical como num plano horizontal (cf. Ferry, 1989: 21-22).

\section{Linguagem e interação}

Retomemos o diagnóstico da crise ético-moral da comunicação pública, equacionada como o resultado da subordinação sistémico-funcional desta aos complexos institucionais anteriormente referidos. A questão crítica central relaciona-se com o facto de os fluxos de comunicação dos media, nestas condições, se apresentarem organizados de um modo tendencialmente unidirecional, conferindo assim aos interlocutores marcas de poder perfeitamente distintivas (e seletivas), em função dos lugares que aos mesmos são destinados nesses mesmos fluxos (como emissores, como recetores, como referentes, etc.). As consequências daqui resultantes são da maior importância a nível de condição ética e de estatuto moral reconhecidos a cada indivíduo, e ainda, de forma mais ampla, no que diz respeito às possibilidades (recursos) que são postas à disposição de cada indivíduo para poder construir a sua própria trajetória social - as condições específicas de liberdade e de autonomia.

A pesquisa comunicacional, de um modo geral, tem vindo a reunir um corpo relevante de conhecimentos sobre este tipo de incidências ético-morais, decorrentes de uma forma de poder dos media mais próxima da sua dimensão mais eminentemente institucional no quadro das sociedades complexas dos nossos dias. Mas determinadas análises mais catastrofistas mostram alguma 
dificuldade em dar conta de todos os aspetos contraditórios que aqui se encontram envolvidos, acabando com muita facilidade por perder de vista um sentido propriamente prático de interpelação ético-moral da comunicação pública. Por muito extraordinário que seja o poder dos dispositivos mediáticos - mesmo quando hiperbolizados ao mais elevado nível pelas novas tecnologias, como dispositivos simulacrais (cf. Kellner e Best, 1988: 60-65) -, esse poder é sempre, ainda assim, um poder condicional: as vantagens em termos de controlo e manipulação que o domínio privilegiado destes meios oferece (por exemplo, na definição intencional de uma dada imagem de si, na autoapresentação e na construção de representações idealizadas da realidade, etc.) - tudo isto tem sempre como reverso da medalha uma agudização de determinados fatores de risco para o self (por exemplo, uma exposição de si altamente saturada, um controlo mais aleatório sobre as diversas «regiões» de exposição do indivíduo (cf. Goffman, 1959: 109 e sg.s), para referir apenas algumas situações mais óbvias ou comuns).

A ideia de um poder ilimitado dos media - e de uma comunicação pública irremediavelmente comprometida em termos ético-morais - é ainda contrariada por uma outra razão fundamental (mas nem sempre devidamente considerada a nível de pesquisa): apesar de subordinados a uma estrutura tendencialmente unidirecional, os media em nenhuma condição, porém, podem dispensar (ou erradicar em absoluto do seu interior) uma certa capacidade de resposta por parte dos recetores. Os media operam a partir de "mapas de sentido" ideologicamente definidos, estabelecidos em estreita proximidade com as estruturas de poder dos sistemas sociais, mas estamos a falar sempre, em todo o caso, de um sentido "dominante e não "determinado", pois é sempre possível ordenar, classificar, estabelecer e descodificar qualquer acontecimento através de mais do que um "mapeamento" (Hall, 1980: 57). Com os media, como logo de início referimos, não apenas o universo dos destinatários das mensagens se alargou extraordinariamente, mas também se expandiram em conformidade as margens de imprevisibilidade dos processos comunicacionais; mais ainda, pela própria natureza dos dispositivos em questão, os mecanismos de controlo sobre as respostas produzidas perderam em grande parte a sua tradicional eficácia (própria dos processos de comunicação convencionais), tornando-se assim impossível em termos práticos a contenção da multiplicidade de fluxos de sentido gerados a partir dos media; e na base dos quais novos «mapeamentos da realidade» podem (e estão de facto) a todo o momento ser construídos. 
Os mais recentes acontecimentos das ruas do Islão aí estão para o provar. Ou será ainda (mais uma vez...) o nosso incorrigível desconhecimento do "Outro» que assim nos faz crer? E eu disse «Islão», ou será a «rua árabe»? Na verdade, nada disto soa (ainda) muito bem...Só mesmo um pedido: por favor, não me "sufoquem» mais uma vez com novas tecnologias a pretexto destes mais recentes acontecimentos. Todos sabemos que muitas outras revoluções tiveram o seu lugar na história muito antes destas tecnologias, e também que não será por causa delas que o conceito de "revolução» voltará ao léxico da Sociologia contemporânea (das sociedades desenvolvidas).

Avancemos então, pois estamos agora em condições de dar um novo passo neste excurso pela ideia de Crise. Vimos que o funcionamento dos media se constitui como um motivo de preocupação, se não mesmo uma ameaça, em termos axiológicos - mais do que pelas características estruturais dos dispositivos, sobretudo em virtude dos seus quadros institucionais. Isto não impede, contudo, os media de manterem em aberto a possibilidade de atualização de outras orientações de funcionamento, mais promissoras no que diz respeito a uma capacidade de gerar novas formas de experiência coletiva, processos de intercompreensão, discursos e linguagens inovadoras mais solidamente ancorados no domínio simbólico das experiências de vida. As questões éticas e morais da comunicação pública são assim indissociáveis destas novas possibilidades de realização de uma vida melhor - uma vida mais bela e mais justa (se é permitido o toque poético). De um ponto de vista estritamente empírico, a organização da comunicação pública põe hoje em evidência muito claramente uma intenção colonizadora por parte dos media funcionais; mas em termos normativos, a capacidade de refletir criticamente (e de inverter) esta situação mantém-se em aberto, o que significa que a possibilidade de uma transformação emancipatória dos media existe de facto - e também a possibilidade, assim, de se redimensionar a comunicação pública em função de valores, normas e regras sociais legitimamente constituídas.

Vejo, porém, esta dimensão dos media como sustentável sobretudo (ou mesmo apenas) pelo lado dos recetores - dito de uma outra forma, basicamente como um exercício de cidadania. A partir daquele ponto, em concreto, em que a quase-interação dos media (cf. Thompson, 1995: 87 e sg.s) se conecta de alguma forma com os processos de interação social comuns, onde as práticas de receção 
e de apropriação simbólica das mensagens mediáticas se ligam mais estreitamente com os contextos informais e plurais da vida quotidiana.

Um dos contributos mais relevantes da pesquisa neste âmbito tem por origem, precisamente, os estudos de receção, que possibilitaram o afastamento de vez de uma imagem redutora dos interlocutores enquanto recetores absolutamente passivos. Os sujeitos na sua relação com as mensagens e os discursos dos media assumem estratégias de interpretação diferenciadas, a partir das redes sociais de comunicação nas quais os próprios se encontram inseridos - redes estas que funcionam em paralelo, isto é, são precedentes e concorrentes em muitas situações com as dos media. Deste modo, os sujeitos têm possibilidade de sintetizar através de formas originais (inclusive até de contrariar) os conteúdos que lhes chegam. A receção como um padrão de interpretação alinhado com a estrutura da oferta deve, assim, ser considerada como uma hipótese, mas não mais do que isso (apenas uma das hipóteses em aberto), outros padrões de receção encontram-se disponíveis, a partir de estratégias interpretativas que são desenvolvidas de uma forma mais ou menos autónoma a partir dos próprios recetores - interpretações alternativas à oferta disponibilizada, ou estabelecendo com esta articulações mais complexas e variáveis (cf. Hall, 1980: 59-61).

Situamo-nos em pleno domínio da "política da significação", o território a partir do qual se vão progressivamente definindo os sentidos dominantes, mas não de uma forma determinística: estes sentidos são sempre o resultado de certo modo contingente de determinadas «lutas discursivas». Stuart Hall tipifica estas lutas recorrendo a um esquema de posições variáveis na relação que se estabelece entre a produção e a receção de mensagens, definindo-se esta, por assim dizer, entre dois pontos limite: num extremo, a perfeita adaptabilidade, no outro extremo, uma oposição/resistência irredutíveis (cf. Hall, 1980: 59-61). Considero o terreno onde ocorrem estas lutas o locus propriamente dito para uma interpelação ética dos media, onde se joga o desafio ético e moral crucial da comunicação pública: de um lado, alinhando-se valores e normas sociais, e do outro, formas de dominação e controlo (associadas ao poder e ao dinheiro).

Permitam-me agora um breve insight para esclarecer melhor o intitulado deste exercício. Equacionada a questão ética e moral dos media nestes termos, estamos em condições de compreender um pouco mais sobre o seu alcance: são questões éticas e morais que dizem respeito, em primeira instância, ao próprio 
funcionamento dos media (às mensagens que circulam no interior destes), mas que não se limitam a este horizonte, abraçando a comunicação pública em toda a sua plenitude. Podemos mesmo dizer que as questões éticas e morais da comunicação dos media só são realmente importantes pelo impacto mais geral que as mesmas têm sobre a comunicação pública (global), ou pelo impacto que desta recebem; ou seja, na medida em que elas próprias ajudam a dimensionar a (e são dimensionadas pela) comunicação pública nesses mesmos termos e, assim, em última análise, a própria vida pública em geral e a organização das sociedades numa base axiológica.

Este quadro visto pelo prisma das dificuldades e obstáculos que hoje se colocam à comunicação pública tem já a chave de compreensão do título proposto: uma crise - dos media (e da sua comunicação) - que tem como efeito a normalização (uma naturalização de forma reificadora) de uma outra crise maior - ou melhor, das várias crises estruturais das sociedades complexas dos nossos dias (as crises de regulação e as crises de legitimidade, do sistema económico capitalista e do sistema político das democracias de massa do Estado Social) (Habermas, 1973: 68 e sg.s). Por que motivo falo de "normalização»? Porque os media procedem, de certo modo, a uma descontinuação da comunicação - no sentido em que esta é sujeita como que a uma reciclagem informacional. E se o recurso simbólico da linguagem é assim exaurido, não podemos deixar de ficar irremediavelmente limitados na nossa capacidade de pensar tudo o resto: de conhecer de uma forma minimamente racional os problemas que se nos colocam, o nosso meio envolvente, e de poder continuar a procurar melhores respostas para estes problemas (num futuro aberto).

Agora quase mesmo para terminar, uma chamada de atenção. Referi a propósito da receção que as lutas discursivas, mesmo quando focalizadas nos media, não se situam à margem das redes de comunicação e dos sentidos constituídos da interação comum. Mas é também verdade que as relações entre os diferentes planos da interação, ou as relações entre os respetivos processos de comunicação, não obedecem a um padrão uniforme; assim como cada um destes planos não pode, também, ser definido per si de uma forma rígida e homogénea: os media tanto podem promover como inibir os processos interlocutórios a nível da interação social e da comunicação quotidiana, mas esta, por seu lado, também tanto pode estimular como desincentivar uma receção de carácter mais comunicacional dos discursos dos media. É evidente, pois, que a dimensão ético-moral 
da comunicação pública se joga a um nível muito mais geral que o simples funcionamento dos dispositivos mediáticos.

Assim, a melhor formulação que encontro para a pergunta-resposta à atual crise (da comunicação pública) é a seguinte: que condições permitem aos media atuar como um elemento enriquecedor dos processos simbólicos (numa conexão criativa com as práticas de significação em geral)? Ou, em sentido contrário, quais os fatores que favorecem uma intervenção dos media redutora desses mesmos processos simbólicos, isto é, que limita as formas de expressão convencionais e as rotinas linguísticas comuns?

São possibilidades distintas que aqui estão em equação e com significados opostos em termos éticos e morais. Isto apesar de nenhuma destas possibilidades poder ser à partida recusada analiticamente: nas condições atuais, qualquer das hipóteses tem a sua própria pertinência empírica, considerando a dinâmica plural, contingente, mas ainda assim não programável das nossas sociedades, ou seja, em face de um processo de desenvolvimento que se encontra perfeitamente em aberto.

Mas aberto mesmo em todos os sentidos - até na (pior) possibilidade de um maior fechamento.

Ou seja, se uma saída para a crise está no nosso horizonte, também não podemos afastar liminarmente a possibilidade de acontecer algo de diferente. Porque, de facto, sabemos ainda muito pouco sobre a capacidade humana de resiliência a este tipo de adversidades: haverá mesmo limites para uma descontinuação da comunicação e para a exaustão simbólica da linguagem?

Tantas fronteiras não imaginadas têm sido sucessivamente ultrapassadas, que até a pergunta proibida deve poder ser formulada: o humano estará mesmo sujeito a limites comunicacionais?

É com esta interrogação que por agora termino - e é até onde me permite ir este meu espírito cético, ainda que profundamente otimista.

(post scriptum: a este propósito, tanto entusiasmo que por vezes se observa à volta das novas tecnologias faz-me recordar - e compreender melhor - como a crença e a fé são, afinal, coisas tão absolutamente humanas, mas também bastante previsíveis, sobretudo em situações de maior incerteza ou adversidade; e é de novo o tema da "teologia dos media" que aqui nos assalta, mas a que prometi desta vez resistir - até uma próxima oportunidade). 


\section{BIBLIOGRAFIA}

DAHLBERG, Lincoln (2011), "Web 2.0 divides: a critical political economy», Media $\&$ Jornalismo, n. ${ }^{\circ} 18$, Lisboa

FERRY, Jean-Marc (1989), "Les transformations de la publicité politique», Hermès, n4, Paris

GOFFMAN, Erving (1959) The presentation of self in everyday life, N. York, Penguin, 1980

HABERMAS, Jürgen (1962) The structural transformation of the public sphere: an inquiry into a category of bourgeois society, Cambridge, Mass., The MIT Press, 1991

HABERMAS, Jürgen (1973) Raison et legitimité: problems de legitimité dans le capitalisme avancé, Paris, Payot, 1978

HALL, Stuart (1980) "Encoding/Decoding», in Paul Marris e Sue Tornham (ed.s), Media studies: a reader, Edinburgh, Edinburgh University Press, 1999

KELLNER, Douglas e BEST, Steve (1988) «Watching television: limitations of post-modernism», Science as Culture, n. ${ }^{\circ} 4$, London

LUKE, Thimothy W. e WHITE, Stephan K. (1987) "Critical Theory, the information revolution, and the ecological path of modernity", in FORESTER, John (ed.), Critical Theory and public life, Cambridge/Mass., The MIT Press

MEAD, George Herbert (1934), Self, mind and society, Chicago, The Chicago University Press, 1967

THOMPSOM, John B. (1992) Ideology and modern culture, Cambridge, Polity Press

THOMPSOM, John B. (1995) The media and modernity: a social theory of the media, Cambridge, Polity Press

YOUNG, T. R. (1987) «Information, ideology and political reality: against Toffler», in SLACK, Jennifer D. e FEJES, Frede (ed.s), The ideology of information age, N. Jersey, Ablex Publishing Corporation 
(Página deixada propositadamente em branco) 
Isabel Ferin Cunha

FLUC

\section{Crise, Corrupção Política e Media}

\section{Introdução}

Este artigo tem como objetivo discutir as relações entre crise, corrupção política e os media. Inicia-se a exposição apresentando diversas aceções dos conceitos anteriormente referidos, tendo em conta a sua etimologia, as definições de dicionários gerais e das áreas disciplinares, bem como os conceitos apresentados nos estudos sobre os media e à ciência política. Disserta-se sobre os conceitos de crise e corrupção política tendo como exemplos o contexto europeu e português Em seguida, recorrendo-se a uma revisão da literatura, estabelece-se as relações entre crise e corrupção política destacando-se os fatores singulares que estão na génese da atual crise internacional e portuguesa. Estas reflexões serão posteriormente conectadas aos fenómenos de corrupção e às suas representações nos media bem como ao papel que estes exercem na denúncia e prevenção. Apoiam-se estas afirmações nos estudos realizados pela organização não-governamental Transparência Internacional e nos índices que divulga, assim como nos estudos sobre as perceções sociais da corrupção em Portugal. Salienta-se, ainda, as questões relativas à transparência da informação e dos processos de comunicação sobre a governação presentes nos media.

Ao longo do artigo toma-se como exemplo alguns estudos empíricos sobre a cobertura de atos de democracia na imprensa e na televisão e apresentam-se algumas imagens a título ilustrativo. Esta estratégia tem como objetivo cotejar definições concetuais e a revisão de literatura com as representações da crise e da corrupção política nos meios de comunicação. 
Etimologicamente a palavra crise tem a sua origem no grego krisis, que significa separação, disputa, decisão, sentença ou juízo definitivo. No latim crisis designa alteração, desequilíbrio repentino; estado de dúvida e incerteza; tensão, conflito (Cunha, 1982: 228). A origem etimológica de crise e os seus sentidos, assim como as definições encontradas nos dicionários gerais, apontam para variados campos disciplinares, como a medicina - alteração para melhor ou para pior no curso de uma doença - a economia - momento decisivo de um negócio - e a política, quando um governo, partido ou político, se encontra em dificuldades ou quando há um hiato de poder. A palavra crise pode também estar associada à moral e resultar de um conflito de sentimentos ou valores.

Norberto Bobbio no seu Dicionário de Política (2004: 303-306) define crise como um momento de rutura no funcionamento de um sistema e considera que as crises podem ser caraterizadas através de três elementos: imprevisibilidade, duração limitada e incidência no funcionamento do sistema. Para compreender uma crise é necessário ter em conta os contextos internos e externos que a antecedem e as mudanças no sistema que a originaram. Na fase da crise, propriamente dita, deve-se dar especial relevância para as questões de tempo e espaço que uma crise envolve e para os atores e protagonistas que se encontram em jogo. Bobbio considera que as crises políticas e as crises económicas estão intrinsecamente ligadas, tanto a nível nacional como internacional, como demonstra a crise económica internacional de 1929 a 1932 que teve severas repercussões sobre os sistemas políticos nacionais. Assim, as crises podem ter uma origem interna ou externa ao sistema e evoluírem em função de picos, o que quer dizer que ao longo da duração de uma crise podem sobrepor-se outras crises, provocando sobrecargas nos sistemas políticos, económicos, jurídicos e sociais.

O mesmo autor distingue ainda as crises do sistema, as governamentais e as internacionais. A crise do sistema está associada a alterações do regime político, bem como a mudanças nos mecanismo e dispositivos jurídicos e constitucionais, como por exemplo, o fim de um regime monárquico e a implantação de uma república, ou o fim de um regime ditatorial e o início de uma democracia. Ainda dentro da crise do sistema, inscrevem-se as transformações das relações 
socioeconómicas que incluem as relações de produção, a distribuição de propriedade e de rendimentos e a conceção de família (Bobbio, 2004: 304). Convém notar que os dois aspetos focados estão profundamente interligados, o que faz com que não haja mudanças de regime sem alterações nas relações socioeconómicas, nem alterações socioeconómicas sem substanciais mudanças na conceção e desenho de um regime.

As crises governamentais estão relacionadas ao funcionamento do subsistema Governo e podem ter origem em fatores internos, inerentes ao contexto e estrutura governamental, ou externos, referentes às relações com a sociedade ou com aspetos derivados de conjunturas internacionais desfavoráveis. O autor assinala que um dos elementos determinantes da crise de governo advém das relações entre classe política e sociedade e pode depender da falta de representatividade da classe política no poder sendo que a institucionalização dos procedimentos com vista a solucionar as crises governamentais têm como objetivo controlar os danos que possam afetar o regime (Bobbio, 2004: 3005).

Crise internacional é um conceito que teve a sua origem nas relações diplomáticas e políticas entre países. Historicamente o conceito esteve sempre associado a conflitos, a guerras e às ambições hegemónicas de determinados países. Na modernidade este conceito aplica-se às relações económicas e às disputas entre países, encabeçadas por partidos e grupos de interesses instalados nos governos, empreendidas com vista a obter vantagens económicas, financeiras e tecnológicas relativamente a acordos. Segundo Bobbio (2004: 305) há uma enorme vantagem em analisar as crises internacionais do ponto de vista da informação disponível, da qualidade e número dos atores envolvidos, bem como dos processos de decisão e resultados alcançados.

A recente crise internacional eclodiu nos mercados em setembro de 2008 despoletada pela falência do banco Lehman Brothers mas, em Portugal, vinha-se arrastando desde o início do milénio, com crescente endividamento interno e externo, baixas taxas de crescimento do PIB, aumento do desemprego e dificuldades em enfrentar a abertura aos mercados emergentes. Apesar do governo socialista, que tomou posse em fevereiro de 2005, ter nos primeiros anos de legislatura reequilibrado o défice e ter dado algum folgo à economia, a crise internacional acabou por vir anular estes esforços. A crise internacional atinge sobretudo o Ocidente, Europa e Estados Unidos, com grandes défices públicos 
e privados e crónica dependência de financiamento externo. Países emergentes, como o Brasil, a China, a Índia e a Rússia, não têm sido afetados da mesma maneira estimando-se crescimentos económicos entre os quatro e os oito por cento.

\section{Crise e corrupção}

No grego, a palavra phthora, corrupção, é o contrário do termo geração sendo que ambos os conceitos apontam para a mudança substancial de caraterísticas que estão associadas à natureza das coisas que podem "chegar a ser" (geração) e "deixar de ser" (corrupção). Assim, para Aristóteles (2005), a corrupção é um movimento de mudança das coisas da natureza, que vai do algo ao não ser desse algo. Nesta aceção, a degeneração, putrefação ou destruição é um processo profundo da transformação dos seres, não necessariamente negativo, que tem em vista a mudança de sua matéria. O conceito de corrupção, do latim corruptione, surge no Dicionário etimológico da língua portuguesa (Cunha, 1982: 203) com dois campos semânticos paralelos. O primeiro aponta para a ideia de estragar e decompor; o segundo envolve um sentido moral mais evidente como perverter e depravar. Estes campos semânticos acentuam a visão "negativa" da conceção de corrupção enunciada pela definição grega e por Aristóteles, ao mesmo tempo que alastram aos sentidos que envolvem a utilização da palavra crise na atualidade.

Rose-Ackerman (1999) na discussão que empreende sobre crise e corrupção, reflete que a crise gera mudanças políticas, económicas, sociais e morais. Ao mesmo tempo, ela é um fenómeno que provoca o afastamento dos cidadãos dos seus governantes e tende a provocar uma despolitização do espaço público, abrindo campo a uma deslegitimação do sistema político e das instituições públicas. A economia é o vetor preponderante das crises na história contemporânea, ten-

dendo a defraudar as expectativas dos cidadãos e das sociedades e contribuindo, de forma inequívoca, para o aumento de fenómenos de corrupção, nas suas múltiplas variantes. Acresce que as crises provocam, também, uma escalada de reivindicações sociais que, por sua vez, levam os atores e agentes políticos e económicos a limitar direitos políticos e sociais, nomeadamente através do controle da informação. As crises promovem ainda o escamoteamento de aspetos 
micro e macropolíticos e processos de colonização económica dos discursos no espaço público, desenrolando-se, em simultâneo, estratégias de ocultação e manipulação da informação disponível.

Gambetta (2002) defende que, na linguagem comum, corrupção carrega diversos sentidos, sendo que três parecem ser os mais importantes. Numa primeira aceção, corrupção refere-se à degradação do sentido ético de agentes (públicos ou privados) implicando uma falta de integridade moral e a sua consequente depravação. Numa segunda perspetiva, corrupção surge associada a um conjunto de práticas sociais resultantes da degradação de algumas instituições (públicas e privadas), estando por isso o foco da corrupção nas relações institucionais e na organização da sociedade. Um terceiro sentido de corrupção acentua determinadas práticas sociais, com forte componente cultural, como por exemplo presentes, etc., com vista a favorecer ou premiar decisões de agentes públicos ou privados.

A literatura especializada e os media classificam corrupção como um conjunto de ilícitos, de grau e natureza diversos que vão dos "agrados" ao compadrio, à cleptocracia, aos crimes de colarinho-branco e à criminalidade organizada. No entanto, a definição de corrupção, entendida como uma prática, é um fenómeno sui generis com propriedades específicas, que se distingue de outros fenómenos de apropriação indevida, encontrando-se hoje relativamente estabilizada. A perceção social de corrupção envolve elementos de cultura local e nacional, variando, em função dos períodos e dos países, a noção do que é legítimo e legal. Em alguns países, os donativos aos partidos são contra a lei, mas noutros não e em certas circunstâncias são aceitáveis: In Italy the socialist argued that the bribes they took were for their party rather than for personal gain, and that, since there is no other way for them to finance their electoral campaigns, donations should be legalized (Gambetta, 2002: 34)

Assume-se assim que a perceção social da corrupção está inserida na cultura local e nacional e tem que ser enquadrada numa perspetiva diacrónica e sincrónica. Como exemplo, pode-se citar determinadas formas de clientelismo em países do Leste da Europa que sempre estiveram na base da organização social e que no pós-comunisno se fundiram com a corrupção. Para Sajó (2002: 1-21) deve-se fazer uma distinção entre atos individuais de corrupção e as estruturas sociais 
clientelistas, independentemente destas abrigarem, frequentemente, práticas corruptas. Segundo ainda este autor, estes fenómenos acabaram misturando-se no que chama clientelistic corruption tornando-se uma forma estável de organização social que permeia todas as áreas da vida pública. O fim do estado comunista e a consequente fragilidade da economia e das instituições fez com que as populações não tivessem uma perceção clara sobre os efeitos da corrupção quer sobre os procedimentos clientelísticos tradicionais, quer sobre a emergência de novas práticas de corrupção.

A definição mais abrangente de corrupção diz respeito à apropriação indevida de bens ou ganhos, enquanto o esmiuçar do conceito aponta para três grandes cenários: um primeiro em que ocorre uma degradação do sentido ético dos agentes envolvidos; um segundo em que se observa um conjunto de práticas sociais predatórias no interior de determinadas instituições e um terceiro cenário onde instituições e agentes acordam na apropriação indevida de benefícios (Heidenheimer e Johnston, 2002: 3-73).

Segundo Dobel (1978) a corrupção deriva, em grande parte, da escassez de bens disponíveis num determinado momento numa dada sociedade o que tende a promover uma "luta pela sobrevivência" aliada a uma diminuição dos padrões éticos e cívicos. Dobel considera que, neste contexto, os ilícitos surgem sobre a forma de corrupção política, económica e judiciária mas é na política que esta se torna mais evidente em cenários de crise económica. Salienta ainda que a corrupção política é um fenómeno historicamente inerente aos contextos de crise e aos fins de regime que esteve sempre no Ocidente associada às crises de legitimação, em que os atores (cidadãos e políticos) qualificam a ordem política como corrupta e empreendem ações com vista à sua alteração.

Na comunicação social portuguesa, as referências à crise são frequentes desde o início do milénio. Estudos empíricos sobre as coberturas dos finais de mandato de primeiros-ministros (Cavaco Silva, 1994-1995; António Guterres, 2001-2002; Santana-Lopes, 2004-2005) na imprensa de referência registam como tema recorrente as questões sobre o défice e a economia (Ferin, 2006: 30-38), bem como sobre a"crise", como se pode ver com duas capas de jornais periódicos publicadas no final de mandato do primeiro-ministro Cavaco Silva (1995). 

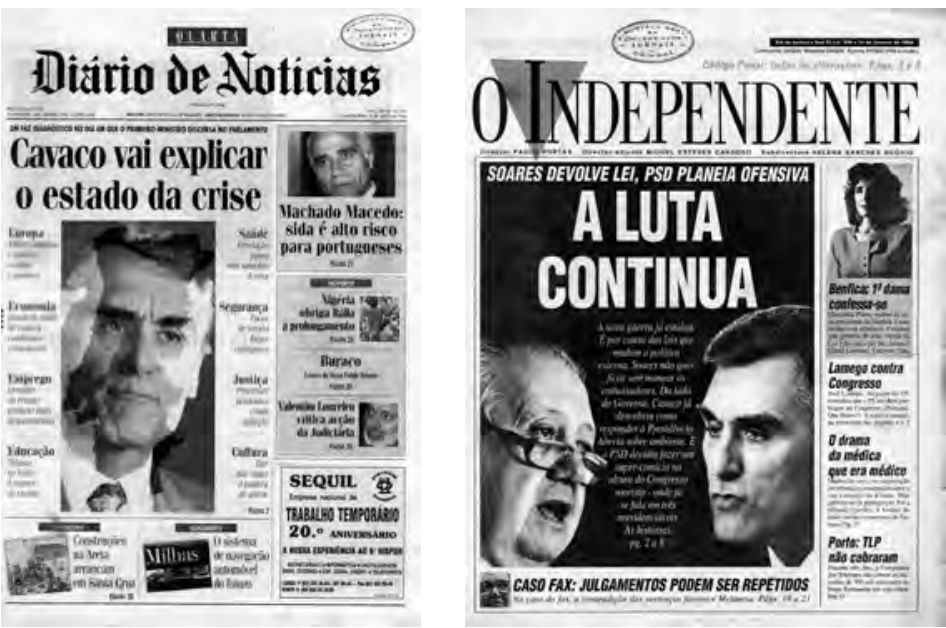

Fonte: Ferin, I. (coord.) (2007)

Na cobertura das eleições legislativas de 2005 (Memorandum, 2005) entre os temas dominantes das candidaturas, embora ainda apresentados sobre diversas perspetivas, estão já assinalados a situação das finanças e a alusão a ilícitos na governação.

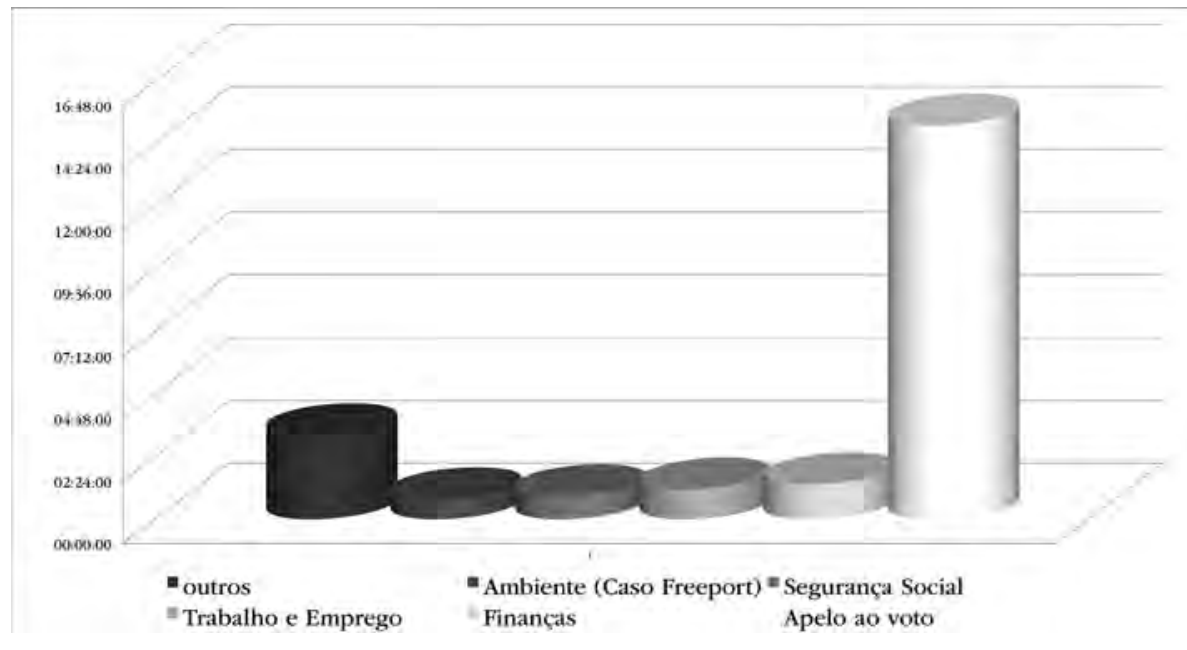

Fonte: Memorando, Legislativas 2005 
Num estudo empírico realizado pelo CIMJ (Centro de Investigação Media e Jornalismo), solicitado pela Entidade Reguladora da Comunicação, sobre as Legislativas de 2009, os temas mais focados nos canais generalistas pelos partidos, num total de 1043 registos, foram, "Ações de Campanha" (42, 3\%, 441 registos), "Economia, Finanças e Crise" (19, 9\%, 208 registos), "Ambiente" (6, 0\%, 63 registos) e "Escândalos e Processos judiciais" (5, 4\%, 56 registos). Nos canais de acesso condicionado, num total de 630 registos, os temas "Escândalos e Processos Judiciais" (9, 7\%, 61 registos) e "Economia, Finanças e Crise" (4, 9\%, 31 registos) ocupam, respetivamente, o terceiro e quarto lugar na cobertura das eleições.

Estes exemplos retirados de estudos empíricos sobre atos de democracia ilustram que a associação entre crise e corrupção tem estado permanentemente nos meios de comunicação e apresentam grande visibilidade no espaço público mediático português. Esta visibilidade justifica que, nos últimos cinco anos (2005-2010), a perceção pública sobre o aumento da corrupção em Portugal tenha vindo a refletir-se nas alterações de posição do país na listagem divulgada anualmente pela Transparency International no Global Report. Em 2006,

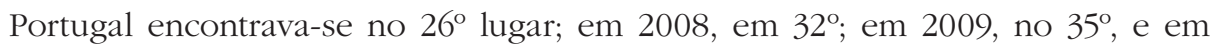
2010 voltou à $32^{\mathrm{a}}$ posição.

\section{Corrupção política}

A corrupção política é entendida como o abuso de poder em benefício próprio de agentes políticos democraticamente eleitos. Esta situação pode ocorrer durante o exercício de funções públicas, ou após, quando os agentes políticos utilizam o capital relacional adquirido durante o exercício de funções para a obtenção de ganhos indevidos. Este processo envolve um leque diversificado de crimes cometidos por agentes políticos ou ex-agentes políticos. Os ilícitos ocorrem fundamentalmente em quatro situações-tipo: na competição por cargos políticos, no exercício de cargos públicos, na ação de legislar e governar, bem como após o abandono de cargos de governação, mantendo-se, contudo, determinadas funções político-partidárias (Heidenheimer e Johnston, 2002).

A corrupção política articula as áreas da Política (poder), da Economia (empresas e negócios), da Justiça (quadro legal) e dos Media (publicitação da 
informação) (Blankenburg, 2002). Simultaneamente, os tipos mais frequentes de corrupção política surgem sob a forma de fraude, suborno, clientelismo, apropriação indevida de bens, tráfico de influências, favorecimento seletivo e financiamento ilegal de partidos.

Bobbio (2004: 291-292) distingue três tipos de corrupção: a recompensa ou compra de um funcionário público no sentido de influenciar a sua decisão; o nepotismo ou contratação de funcionários baseada em relações de parentesco e não no mérito; o peculato por desvio ou apropriação de fundos públicos para fins privados. O autor considera ainda que a corrupção é uma forma particular de exercer influência que tende a moldar-se ao sistema em que se insere, nomeadamente no que toca à tomada de decisões. Neste sentido, a institucionalização de certas práticas torna previsível o aumento de corrupção, sendo que quanto maior for o âmbito da institucionalização maior será a probabilidade do sistema se corromper.

Bobbio (2004), Blankenburg (2002) e Philp (2002) consideram que as privatizações realizadas no espaço europeu alargado nas décadas de oitenta e noventa contribuíram para o aumento da corrupção em diversos níveis. Salientam, primeiramente, que a mudança de paradigma económico e financeiro veio favorecer determinados grupos de interesses já instalados, que viram aumentados os seus privilégios, assumindo estratégias - tais como a alternância de gestores entre cargos públicos e privados - com vista a influenciar decisões governamentais. A expansão económica e financeira, e o crescimento da sociedade de consumo, nas décadas de oitenta e noventa na Europa, fizeram igualmente emergir uma nova elite dirigente, cujos valores conjugaram práticas políticas tradicionaiscomo clientelismo, nepotismo e familiarismo- com estratégias de sucesso e enriquecimento rápido.

Um dos exemplos deste conjunto de práticas está elencado na cronologia do "Caso Freeport" publicada no Diário de Notícias de 27 de Julho de 2010, que se transcreve em seguida:

MP ENCERROU INVESTIGAÇÃO

Freeport: Cronologia dos principais acontecimentos

27 Julho 2010

Cronologia dos principais acontecimentos relacionados com o processo Freeport, que teve na sua origem suspeitas de corrupção e tráfico de 
influências na alteração à Zona de Protecção Especial do Estuário do Tejo e licenciamento do espaço comercial em Alcochete quando era ministro do Ambiente José Sócrates, actual primeiro-ministro.

Entre os arguidos estão os empresários Charles Smith e Manuel Pedro, João Cabral, funcionário da empresa Smith\&amd Pedro, o arquiteto Capinha Lopes, o antigo presidente do Instituto de Conservação da Natureza Carlos Guerra e o então vice-presidente deste organismo José Manuel Marques e o ex-autarca de Alcochete José Dias Inocêncio.

2002

- Em Março é aprovado o Estudo de Impacte Ambiental do projecto para o 'outlet' Freeport em Alcochete. O projecto já tinha sido chumbado duas vezes. No mesmo dia é decretada no último Conselho de Ministros uma alteração da Zona de Protecção Especial (ZPE) do Tejo que exclui o terreno do 'outlet'.

- Em Junho a Quercus apresenta duas queixas na União Europeia: uma contra o licenciamento e outra contra a alteração da ZPE.

2004

- Em Setembro é inaugurado o espaço comercial Freeport. Com uma área global equivalente a 55 estádios de futebol, o complexo de Alcochete custou cerca de 250 milhões de euros. É o maior outlet da Europa.

- Em Outubro chega à PJ de Setúbal uma carta anónima, que se soube mais tarde ser de Zeferino Boal, então deputado municipal do CDS/PP em Alcochete, que denunciava o alegado financiamento do PS a troco da aprovação do Freeport numa altura em que José Sócrates era ministro do Ambiente e na altura candidato a primeiro-ministro. A Polícia Judiciária (PJ) começa a investigar.

2005

- O semanário 'O Independente' divulgou que José Sócrates foi dado como sendo suspeito de alterar a Zona de Proteção Especial (ZPE) do Estuário do Tejo enquanto ministro do Ambiente.

- Em Janeiro José Manuel Palma e João Matias, da Fundação das Salinas, são ouvidos como testemunhas pela PJ de Setúbal, relatando uma história que ouviram em Alcochete que dava conta de que José Sócrates teria recebido dinheiro para aprovar a construção do Freeport.

- Em Fevereiro são feitas buscas na Câmara Municipal de Alcochete, presidida por José Inocêncio, e em três escritórios: Smith\&Pedro, SAM e SEA. As empresas visadas são de Manuel Pedro e Charles Smith, intermediários no negócio. As buscas da PJ estendem-se à sede do Freeport.

É também interrogada a secretária de Manuel Pedro e uma funcionária da 
Direção Regional do Ambiente.

- Em Agosto, a PJ envia para Inglaterra uma carta rogatória com um pedido de informação sobre movimentos bancários das contas do Freeport. Rui Leitão, funcionário da SAM, é ouvido como testemunha.

2008

- Em Maio é ouvido formalmente o chefe da divisão de urbanismo da Câmara Municipal de Alcochete, depois de três anos sem inquirições por parte da PJ de Setúbal.

- Em Setembro a directora do Departamento Central de Investigação e Acção Penal (DCIAP), Cândida Almeida, avoca o processo justificando que o caso é muito complexo. Em poucos meses realizam-se duas reuniões com a Polícia britânica para troca de informações.

2009

- Em Janeiro a PJ realiza mais buscas domiciliárias, nomeadamente na casa de Júlio Monteiro, tio de José Sócrates, no escritório de advogados Vieira de Almeida e no atelier de arquitectos Capinha Lopes.

- A 10 e 17 do mesmo mês, o Ministério Público emitiu comunicados onde esclarecia que, até àquele momento, não havia indícios do envolvimento de qualquer ministro português, do atual Governo ou de anteriores, em eventuais crimes de corrupção relacionados com o caso.

- Em Fevereiro, os empresários Charles Smith e Manuel Pedro foram ouvidos como arguidos no DCIAP, em Lisboa, e ambos ficaram sujeitos a termo de identidade e residência (TIR).

- No dia 18 do mesmo mês, o empresário Júlio Monteiro, tio de José Sócrates, é ouvido como testemunha no Tribunal de Cascais, área da sua residência, por procuradores do DCIAP.

- Em Maio o arquitecto Eduardo Capinha Lopes é constituído arguido na investigação. O gabinete de Capinha Lopes foi responsável pelo projecto do centro comercial 'outlet' em Dezembro de 2001 e foi alvo de buscas do DCIAP e da PJ em Janeiro.

- Em Junho, Carlos Guerra, antigo presidente do Instituto de Conservação da Natureza (ICN) que assinou os pareceres decisivos para o chumbo e a posterior aprovação do 'outlet' de Alcochete, em Março de 2002, foi constituído arguido no caso. Dias depois pede a demissão do cargo de Programa de Desenvolvimento Rural (PRODER).

- Também em Junho o ex-presidente da câmara de Alcochete, José Dias Inocêncio, foi constituído arguido no inquérito

- No mesmo mês, José Manuel Marques, antigo vice-presidente do Instituto de Conservação da Natureza (ICN), foi igualmente constituído arguido no 
caso. José Manuel Marques foi consultor da Câmara Municipal de Alcochete na altura em que o 'outlet' de Alcochete foi aprovado.

2010

- No dia 26 de Julho o DCIAP deu por concluída a investigação do processo Freeport.

Fonte: Diário de Notícias, especial Caso Freeport, 27 de julho de 2010

(http://www.dn.pt/especiais/interior.aspx?content_id=1627775\&

especial $=$ Caso $\% 20$ Freeport $\&$ seccao $=$ POL $\%$ CDTICA $\&$ page $=3)$

Segundo Blankenburg (2002) a corrupção política é um fenómeno recorrente que está intrinsecamente relacionado com mudanças de valores políticos, económicos e sociais, bem como a ascensão de novos grupos sociais ao poder. Para este autor um dos fatores que mais determinou nos anos 90, a eclosão na Europa Ocidental de fenómenos de corrupção política foi a mudança de padrões de clientelismo político, que estando inseridos em práticas locais, regionais e nacionais se viram confrontados com avaliações exógenas de cariz internacional.

A visibilidade do fenómeno na comunicação social acentuou-se neste último quinquénio, como demonstra o exemplo apresentado em seguida na revista Visão.

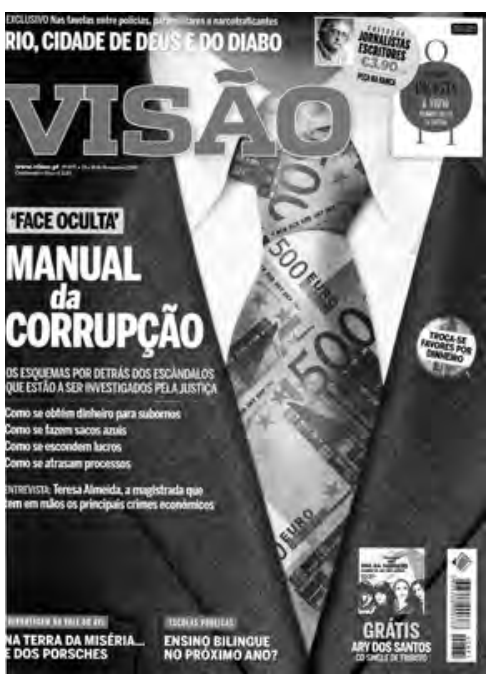

Fonte: Visão, no 871, 12 a 18 de Novembro de 2009 
As transformações das últimas décadas na Europa levaram a que o mundo dos negócios ficasse sobre grande pressão e se instalasse um clima de competição em consequência da globalização. Muitos países europeus foram obrigados a abandonar centenários procedimentos protecionistas, nomeadamente no que concerne à indústria nacional, e a investir em infraestruturas (tais como comboio, aeroportos, telecomunicações, correios e serviços) com vista a facilitar a instalação de empresas multinacionais e o comércio internacional. Este modelo económico abriu campo a uma crescente interdependência entre os negócios e a política, alimentando uma estrutura clientelística. Neste contexto, nos anos 80 e 90 os acordos do GATT, do Banco Mundial, assim como a criação das zonas de comércio livre dentro da Europa, da América e da Ásia, resultaram na abertura dos mercados nacionais e na privatização forçada das empresas dirigidas pelo Estado. As privatizações surgem simultaneamente como oportunidades para novos negócios mas também para novas formas de corrupção política e económica. Em contrapartida, o avanço da globalização e as práticas económicas que a este processo obriga, nomeadamente a homogeneização de procedimentos para concursos e abjudicações, levou à institucionalização de mecanismos de combate à corrupção: Fighting corruption on the side of bribers as well of the bribed has been one of the credos of the globalization efforts (Blankenburg (2002:154). Os países e os governos assumem coletivamente que a corrupção é um inimigo da competição internacional, obrigando assim à promoção de normas para uma justa competição no interior de um mercado livre e sancionando aqueles e aquilo que possa criar obstáculos a esta situação.

Os tipos mais frequentes de corrupção política, como se disse anteriormente são a fraude, o suborno, o clientelismo, a apropriação indevida de bens, o tráfico de influências, o favorecimento seletivo e o financiamento ilegal de partidos. Em Portugal, este último aspeto tem dominado os casos mais mediatizados como se constata no estudo empírico o "Escândalo Político em Portugal: 1991-1993 e 2002-2004", de Bruno Paixão (2010). Entre estes, que envolveram alegadas práticas de corrupção política e económica estão os casos: "Fax de Macau" (1991); "Caso Costa Freire" (1991); "Faturas falsas do Fundo Social Europeu" (1993); "Caso Moderna" (2002); "Caso Avelino Ferreira Torres" (2004); "Caso Felgueiras" (2004; "Caso Isaltino de Morais/Câmara de Oeiras" (2003). Em grande parte destes 
"casos" são detetalhadas cumplicidades entre o mundo da política, obras públicas e futebol, com a respetiva contribuição para o financiamento dos partidos e dos políticos.

A estes casos ainda se poderiam acrescentar, por exemplo, os casos amplamente mediatizados "CTT/Coimbra", "Freeport", "Face Oculta" e "Submarinos", onde as questões relativamente ao financiamento de políticos e partidos parecem estar sob constante suspeição. Como exemplo, transcreve-se o depoimento do ex-vereador da Câmara Municipal do Porto ao programa Linha da Frente da RTP1.

Programa Grande Reportagem Linha da Frente, RTP1, emitido a 30/03/2011. Título "Afinal de Contas". 40m. Resumo: "Afinal de Contas é uma reportagem sobre as derrapagens financeiras nas obras públicas em Portugal e nas parcerias público-privadas. Este trabalho conta com depoimentos do ex-juiz do Tribunal de Contas, Carlos Moreno, do ex-ministro das Obras Públicas, Ferreira do Amaral e do ex-vereador do urbanismo da Câmara Municipal do Porto, Paulo Morais".

Excertos do depoimento de Paulo Morais: ... o financiamento partidário é calamitoso...envolve duas questões: financiamento dos partidos propriamente ditos e da sua atividade...têm que arranjar recursos e fazem-no nomeadamente através desta nova Lei....Outro aspeto é o financiamento da vida privada dos próprios políticos. Há todo um conjunto de pessoas que gravitam à volta da vida política, os chamados homens da mala, que são aqueles que fazem a intermediação entre o financiador e os partidos que recebem o dinheiro. E hoje as margens de comissionamento neste tipo de negócios, que já é um negócio, estão na ordem dos 40\%. Ou seja alguém vai a um empreiteiro buscar 100 mil euros para dar ao partido e pelo caminho fica com 40 mil e dá 60 mil ao partido... 


\section{Crise, corrupção política e media}

Blankenburg (2002) demonstra que a adesão à União Europeia, de muitos países do Sul e do Leste da Europa, e a consequente desregulamentação dos media, originou uma maior competição pelo valor-notícia e uma nova cultura profissional dos jornalistas, fundada simultaneamente na competição pelo mercado de audiências e nos valores democráticos. A corrupção e o escândalo entraram no quotidiano dos media constituindo um issue sempre com dimensões e valor de mercado crescentes.

Segundo Thompson (2000:40) o escândalo político refere-se a ações ou acontecimentos que implicam certos tipos de transgressões que se tornaram conbecidas de outros e que não são suficientemente sérias para provocar uma resposta pública. O mesmo autor considera que o escândalo está muitas vezes associado à corrupção e ao suborno de tal modo que esses conceitos parecem inextricavelmente ligados (Thompson, 2000:55). Ao mesmo tempo, as democracias liberais reúnem um conjunto de fatores que tendem a promover o escândalo político, nomeadamente estratégias de visibilidade dos líderes políticos, as mudanças de tecnologias de comunicação e de vigilância, as mudanças na cultura jornalística e na cultura política, bem como a crescente regulamentação da vida política.

A crise e a corrupção política são por si só uma matéria-prima para os media pois geram fenómenos de valor acrescentado e é neste contexto que se insere a escandalização, ou seja a apresentação de uma informação sob a forma de escândalo, dentro de uma lógica de crescente competição entre meios de comunicação em busca do mercado das audiências. É necessário, ainda, ressaltar que, num primeiro momento, a imprensa (escrita, radiofónica e televisiva) apostou no jornalismo de investigação, mas o alastrar da crise económica aos media, fez com que se privilegiassem informações oferecidas por fontes anónimas, normalmente localizadas nos tribunais. Como nota Blankenburg (2002: 153), o tom das revelações dos media assume caraterísticas de espetáculo (entretenimento e ficção) servido quotidianamente aos espetadores/consumidores de informação, envolvendo, por vezes, grandes doses de imaginação criativa e algum apelo ao pânico moral, como se nota na chamada da primeira página do jornal Público: 


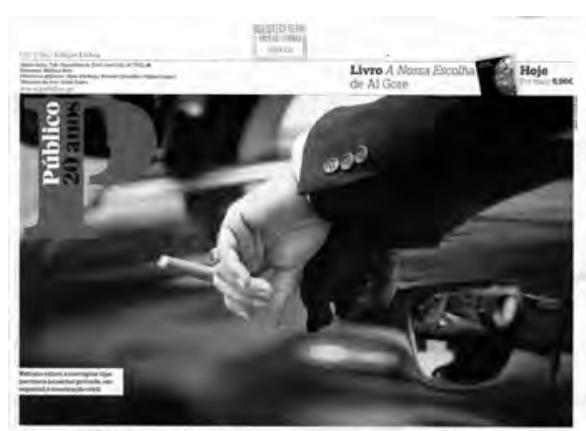

Dos 549 condenados por corrupção em dez anos só 50 tiveram pena de prisão efectiva

Um retrato do Portugal corrupto $\bullet$ Mais de 80 por cento dos inquilidos acham que a comrupcîo

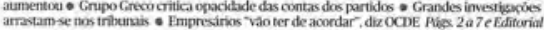

Fonte: Público, Quinta-feira, 9 de Dezembro de 2010

A estes fenómenos convém somar a convergência de interesses dos juízes e dos media no sentido de permitir a ambos enfrentar o sistema partidário. Todavia este procedimento tem como consequências os julgamentos em praça pública e a utilização dos tribunais como palcos de escandalização. A estes fatores acresce a lentidão ou a incapacidade da justiça demonstrar a ilicitude de determinados atos de corrupção o que leva os media e o ministério público a unirem-se no sentido de expor o arguido àquilo que parece ser a sua única e verdadeira punição: o escândalo público. Os media tornam-se muitas vezes um permanente palco de discurso moral e legal, definindo e redefinindo, na praça pública, o que se entende por corrupção política. Ressalva-se, no entanto, que a escandalização da corrupção política tornou-se uma estratégia de denúncia que tende a afetar a classe política e a democracia representativa como um todo, apesar de instrumentalizada por todos os políticos.

O papel dos juízes e do ministério público tornou-se especialmente visível, em diversos momentos das últimas décadas, nos países do sul da Europa. Na Itália dos anos 80, a magistratura adquiriu grande notoriedade encabeçando o movimento "mãos limpas" que evidenciou os tentáculos da corrupção política e das máfias no financiamento dos partidos. Nos anos noventa, em Espanha, foram também notórias as ações do ministério público contra a corrupção, estando assinaladas em Novembro de 2009, 730 investigações a responsáveis, públicos e políticos, de todos os partidos por corrupção.

Conforme escreve Blankenburg (2002: 154) estas diligências da justiça devem-se a uma nova geração de juízes, egressa da democratização do ensino superior 
e do alargamento da base da classe média no sul da Europa. Estes juízes têm menos ligações às elites tradicionais e assumiram, em muitos casos, a luta contra a corrupção como uma missão da sua magistratura. Movimentando-se entre legislação desadequada e morosidades processuais, os jovens juízes são tentados a considerar os jornalistas seus aliados, esquecendo que as informações, uma vez na praça pública, se autonomizam e criam dinâmicas próprias independentes da sua fonte. Como refere Leblanc (1998: 60-70), os media e a justiça têm, pelo menos, dois objetivos comuns: descobrir a verdade e fazer com que publicamente ela seja reposta. No entanto, enquanto o juiz surge aos olhos do cidadão comum como um justiceiro, cuja ação está travada por obrigações e códigos, o jornalista parece estar aparentemente mais livre, movendo-se por uma representação da justiça que transcende os limites da instituição. Esta perceção pública da justiça faz com que os media assumam a intermediação entre poderes, exercendo ora o papel de acusadores, ora de advogados de defesa, ora de juízes nos casos com maior potencial mediático. Nestes caso, é também frequente a violação do segredo de justiça, promovida pelos media através da divulgação de informações de fonte judicial, gerando um conhecimento parcial dos factos designada "informação hipótese" e os julgamentos na praça-pública.

No sentido de minimizar a crise e as denúncias de corrupção política os governos de países democráticos tendem a condicionar a informação e a controlar a informação pública.

Por exemplo, o chamado caso "Face Oculta" envolve procedimentos do governo que apontam para tentativas de controlo da informação, como demonstra a notícias do semanário Expresso:

\section{Sócrates falou do negócio PT/TVI 11 dias antes de negar conhecê-lo}

\begin{tabular}{|c|c|}
\hline $\begin{array}{l}\text { Is do processo 'Face } \\
\text { im marcas de água } \\
\text { das. O Expresso } \\
\text { stagens e despachos } \\
\text { fiu os momentos }\end{array}$ & $\begin{array}{l}\text { Soares comenta outra vez com } \\
\text { Paulo Penedos que "o chefe" pe- } \\
\text { tiu para "ir para la trés meses". } \\
\text { Estas escutas de Sócrates sobre } \\
\text { negdcio PT/rVI identificadas pe } \\
\text { o Expresso sảo diferentes das co- } \\
\text { ias de cinco chamadas de voz e } \\
65 \text { mensagens escritas guardadas }\end{array}$ \\
\hline
\end{tabular}


O papel dos media, face ao fenómeno da corrupção é reconhecido por todas as instituições internacionais tais como a ONU, a OCDE, bem como as organizações políticas (EU), económicas (Banco Mundial, FMI) e não governamentais (Transparency International). Na perspetiva destas instituições, os media podem desempenhar um importante papel na denúncia do fenómeno e, em simultâneo, contribuir para a consciencialização da opinião pública e defesa dos interesses públicos (Heidenheimer e Johnston, 2002; Sousa e Triães, 2008).

Os intervenientes nacionais e internacionais que se debruçam sobre esta problemática concordam, contudo, que nos países ocidentais, a perceção do fenómeno é influenciada pelo tipo de cobertura jornalística realizada pelos media, nomeadamente pelo que alguns autores designam como indústria mediática do escândalo (Heidenheirmer, Johnston, Levine, 1999; Thompson, 2000).

Em Portugal há alguns estudos que se debruçam sobre a perceção da corrupção nos media. Num trabalho realizado em 2006 e 2007, sobre os traços caracterizadores da perceção que os portugueses associam às práticas de corrupção ocorridas em Portugal, Maia (2009: 115) constatou que a maior parte das pessoas recolhe informação acerca das práticas de corrupção e constrói a sua perceção acerca do problema, tendo como base os canais televisivos, bem como a imprensa. Outros estudos realizados por Sousa e Triães confirmam relativamente aos anos de 2007 e 2008, a mesma realidade. Poeschl e Ribeiro (2010), num artigo sobre as representações sociais da corrupção, apuraram que são os acontecimentos nacionais que se impõem à mente dos cidadãos, os negócios fraudulentos que povoam o mundo do futebol e da política e das instituições financeiras. A informação parece resultar dos enquadramentos mediáticos mais frequentes que tendem a destacar pessoas singulares ou casos específicos e a negligenciar análises mais abrangentes dos fenómenos.

Estes trabalhos sobre as representações sociais da corrupção focam a importância dos media para a perceção da corrupção pelos portugueses (Sousa e Triães, 2007, 2008; Maia, 2009; Sousa, 2009, 2010) mas não se debruçam sobre a relação dos media com a corrupção política ou sobre a cobertura jornalística dos fenómenos de corrupção. Como exceção refere-se um breve ensaio publicado em 2008, no $\mathrm{n}^{\circ} 12$, da Revista Trajectos, do ISCTE, da autoria de Isabel Babo-Lança, intitulado $A$ corrupção como problema público e a nova ética da confiança. Neste artigo de treze páginas a autora aborda os discursos sobre a 
corrupção e discorre sobre as questões de denúncia e desconfiança no espaço público. O livro do jornalista José Vegar e da procuradora Maria José Morgado, intitulado Fraude e Corrupção em Portugal: O inimigo sem rosto, de 2003, disserta no capítulo quinto sobre as relações entre justiça e comunicação social, incidindo sobre o segredo de justiça e as fugas de informação para os media. No trabalho de Mestrado publicado sob o título O escândalo político em Portugal, Bruno Paixão (2010) procura observar como o escândalo político, envolvendo em geral um fenómeno de corrupção política, se torna mercadoria interessante para os jornalistas e para os adversários políticos, eventuais beneficiários da aniquilação da vítima do escândalo. Por último, em março de 2011, foi editado o livro Transparência, Justiça, Liberdade: Em Memória de Saldanha Sanches, coordenado por Luís de Sousa e Domitília Soares, onde João Triães, no capítulo 1, 1 aborda o tema Acesso à informação, media e corrupção em Portugal.

Neste contexto, dado que a corrupção se pratica de forma discreta, os meios de comunicação têm um papel preponderante na difusão da informação sobre casos de corrupção (Tumber e Waisbord, 2004), mas também podem utilizar a informação para aumentar as suas vendas e obter maiores audiências (Shea, 2009). Como refere Shea (2009), só agentes que conhecem as práticas e os meandros de uma instituição têm capacidade de avaliar os procedimentos ilícitos sendo que estes nem sempre estão na posição institucional certa para os denunciar, optando muitas vezes por os silenciarem. Nesta linha, Lindstedt e Naurin (2010) consideram que a existência ou não de corrupção, tem uma correlação muito forte com a independência dos media e a liberdade de informação, constituindo estes fenómenos um indicador da qualidade da democracia e da liberdade de expressão.

\section{Algumas conclusões: notas sobre a transparência}

A sobreposição das diversas crises (acional, internacional, nacional) e as denúncias de corrupção constituíram conteúdos recorrentes, ao longo destes anos, nos meios de comunicação portugueses. Os media não ficaram imunes aos ciclos económicos dado que integram grandes grupos económicos com áreas diversificadas de interesses e ligações internacionais. A retração 
do investimento publicitário, associado às movimentações pelo controle, privado e público, das empresas de Comunicação, Informação e Media, criaram um clima de grande crispação dentro das redações das televisões, jornais e rádios, e entre estas últimas, o governo e as diversas fações partidárias. Entre 2008 e 2011 sucedem-se as acusações de interferência do governo, sobretudo do primeiro-ministro José Sócrates, junto de empresas de Comunicação Social, visando condicionar informações menos favoráveis à governação socialista. O tema da transparência tornou-se mais um issue a juntar à crise, à corrupção e ao escândalo político.

Transparência é um conceito entendido como a disponibilização de informação sobre uma instituição pública a agentes internos e externos para que possam formar uma opinião sobre ações e processos a empreender face a essa instituição. Para que haja transparência é determinante conhecer-se quem são os agentes que publicitam a informação e quais as relações que existem (ou não existem) entre as empresas dos media, do sistema político e partidário e dos grupos mediáticos, nomeadamente com a imprensa. A partir da identificação destas relações é que se pode aferir os critérios de publicitação de determinados acontecimentos, as agendas, assumidos pelos meios de comunicação os quais influenciarão não só os assuntos sobre os quais as pessoas irão pensar, mas também os pontos de vista que moldam a opinião pública (Iyengar e Simon, 1993).

A partir da análise de dados internacionais sobre diversos países Lindstedt e Naurin (2010), num artigo intitulado Transparency is not enough: making transparency effective in reducing corruption, confirmam que, tornar a informação acessível ou promulgar legislação sobre a corrupção, não é condição suficiente para a combater ou diminuir. Os autores consideram que as medidas tomadas pelos agentes públicos e governamentais com vista a tornar as instituições transparentes têm mais possibilidades de não se efetivarem, ou terem menos sucesso, que as empreendidas pelos cidadãos organizados. Estas conclusões apontam para o papel determinante dos cidadãos no combate à corrupção, nomeadamente por meio da consciencialização dos danos causados à democracia e à economia, na assunção de formas de cidadania ativa e através da ação de uma imprensa independente.

A desconfiança face às medidas tomadas pelos governos/estados fundamenta-se na perceção que existem dois tipos de transparência: a que é controlada 
pelo agente produtor da informação (o ator que produz a informação assume a responsabilidade de a publicitar) e aquela que não é controlada pelo agente produtor, ou seja a informação que é publicitada por quem não a produz e não está envolvido no processo. A primeira forma de transparência tem mais possibilidades de se revelar ineficaz, simulando apenas procedimentos formais de transparência.

Para que a transparência seja de facto um meio de prevenir a corrupção é necessário disponibilizar a informação mas, também, fazer com que chegue de forma compreensível aos potenciais prevaricadores, inibindo as suas condutas criminosas, e aos cidadãos, alertando-os para a dimensão dos crimes. Conjugam-se, assim, três fatores no combate à corrupção, a transparência das instituições, a publicitação alargada e a responsabilidade cívica.

\section{BIBLIOGRAFIA}

Aristóteles (2001). Da geração e da corrupção. São Paulo: Landy.

Aristóteles (2005). Sobre a Geração e a Corrupção. Lisboa: INCM.

Avritzer, L., Gignotto, N., Guimarães, J., Starling, H. M. M. (org.) (2008). Corrupção: ensaios e críticas. Belo Horizonte: Editora UFMG.

Blankenburg, E. (2002). From Political Clientelism to Outrighy Corruption - The rise of the Scandal Industry, pp. 149-165. In: Kotkin, Stephen \& Sajó, A. Political Corruption in transition: a sceptic's handbook. Budapeste: Central European University Press.

Campus, D. (2010). Mediatization and Personalization of Politics in Italy and France: The Cases of Berlusconi and Sarkozy. The International Journal of Press Politics. 15: 219-235.

Bobbio, N., Matteucci, N., Pasquino, G. (2004). Dicionário de Política. 2 vols.12a ed. Brasília: Editora da Universidade de Brasília.

Charron, N. (2009).The impact of Socio-Political Integration and Press Freedom on Corruption. Journal of Development Studies. 39 (4): 1-21.

Cunha, A. G. da (1982). Dicionário etimológico da língua portuguesa. São Paulo: Nova Fronteira.

Dobel, P. (1978). The corruption of the State. Los Angeles. American Political Science Review, 72 (3): 958-973.

Edelman, M. (1976). The Symbolic Uses of Politics. Champaign: University of Illinois Press.

Ferin, I. (coord.) Jornalismo e Democracia. Lisboa: Paulus. 
Filgueiras, F. (2008). Corrupção, democracia e legitimidade. Belo Horizonte: Editora UFMG.

Gambetta, D. (2002).Corruption: An Analytical Map, p. 33-56. In: Kotkin, S. \& Sajó, A. Political Corruption in transition: a sceptic's handbook. Budapeste: Central European University Press.

Heidenheirmer, A. J. \& Johnston, M. (ed.) (2002). Political Corruption: Concepts \& Contexts. (3ed.). New Jersey: The State University.

Jacobs, J. B.(2002). Dilemmas of Corruption Control, p. 81-90. In: Kotkin, S. \& Sajó, A. Political Corruption in transition: a sceptic's handbook. Budapeste: Central European University Press.

Kotkin, S. \& Sajó, A. (2002). Political Corruption in transition: a sceptic's handbook. Budapeste: Central European University Press.

Leblanc, G. Del modelo judicial a los processos mediáticos, pp. 60-70. In: Gauthier, G., Gosselin, A., Mouchon, J. (comps). Comunicacion y Politica. Barcelona: Gedisa.

Lindstedt, C. \& Naurin, D. (2009). Transparency is not enough: making transparency effective in reducing corruption. International Political Science Review. 31 (3): 301-322.

Paixão, B. (2010). O Escândalo Político em Portugal. Coimbra: Minerva.

Philp, M. (2002). Political Corruption, Democratization, and Reform, pp. 57-79. In: Political Corruption in transition: a sceptic's handbook. Budapeste: Central European University Press.

Raboy, M. \& Dagenais, B. (1992). Media, Crisis and Democracy. London: Sage

Shea, D. (1999). All scandal politics is local: ethical lapses, the Media and Congressional Elections. International journal of Press Politics 4:45-62.

Sousa, L. de \& Triães, J. (2007). Corrupção e Ética em democracia: o Caso de Portugal. Lisboa: ObercomBrief.

Thompson, J. B. (2002). O escândalo político: poder e visibilidade na era mídia. Rio de Janeiro: Vozes.

Transparency International (2005). Global Report 2004: Political Corruption. Cambridge: University Press. 
Maria João Silveirinha

FLUC

\section{O SOM DO SILÊNCIO:}

\section{A QUESTÃO DA VOZ NAS SOCIEDADES NEOLIBERAIS EM CRISE}

\section{Crise e neo-liberalismo}

Referindo-se à atual crise económica, o filósofo Esloveno Slavoj Zizek (2009: 9) disse que a verdadeira surpresa não é que o problema económico tenha, de facto, acontecido, mas a facilidade com que se aceitou a ideia de que ele aconteceu do nada e que era imprevisível. Simultaneamente, embora houvesse já muitos sinais indiciadores do colapso financeiro, quando de facto ele ocorreu, estabeleceu-se uma enorme confusão sobre como entendê-lo. A incerteza e incompreensão da situação produziram pânico e muitas histórias que buscaram uma culpa, como é típico das situações de crise. E, quando a primeira reação é de pânico, este reafirma violentamente as premissas básicas da ideologia dirigente. Tal explica que, na crise económica atual, a tarefa central da ideologia dirigente tenha sido "impor uma narrativa que coloca a culpa da crise financeira não no sistema capitalista global em si mesmo" mas "em desvios secundários e contingentes" como a falha do sistema de regulação ou a corrupção das grandes instituições financeiras ou ainda ações levadas a cabo por indivíduos que agiram, maioritariamente, de forma irresponsável e irracional (Zizek, 2009: 19).

Este foco na procura dos culpados do problema económico tende a levar a soluções aparentemente simples para um problema complexo dado que, uma vez aparentemente identificadas as fontes do problema, basta-nos agir sobre elas. Neste caso, a reação constituiu-se no discurso de que bastaria eliminar as maçãs podres que causaram a crise e produzir rapidamente ações apenas impulsionadas pela crença irracional de que seria preciso "fazer alguma coisa", fosse ela qual fosse. 
Destas reações, pelo menos duas consequências se fazem já sentir de um modo profundo no tecido social. Por um lado, as consequências "arrastadas" que aprofundam ainda mais a crise social. É em função delas que Zizeck argumenta que aquilo com que realmente precisamos de nos preocupar não é apenas com as consequências económicas da crise -financeira mas com o modo como esta crise é, ela própria, usada "para impor duras medidas de «ajuste estrutural»" (2009: 20). Por outro lado, como tem sido recordado, o problema de pacotes de estímulo e planos de resgate como os que foram organizados por causa da pressão dos governos para fazer algo rapidamente é que não só eles não funcionam, como produzem uma tendência para minimizar o contexto mais vasto cultural e político que lhe deu forma.

Na verdade, quando a crise é entendida apenas como "matéria económica ou financeira, não conseguimos ver o grande quadro que nos permite formular respostas estratégicas" e projetar "imaginários políticos viáveis do futuro" (Grossberg, 2010a: 296).

Ora, a procura desses imaginários pode partir precisamente do contexto que deu forma à crise e do qual esta não deve ser separada: e esse contexto é do neoliberalismo como doutrina que se refere, em termos gerais, à rejeição da economia do Estado de bem-estar keynesiano e ao domínio da Escola de Chicago da economia política baseada nas doutrinas de von Hayek, Friedman e outros.

Na América, poder-se-á situar o início desta doutrina no último ano da administração americana de Jimmy Carter, e mais claramente na de Reagan. A inspiração ideológica viria, no entanto, da Grã-Bretanha, nomeadamente do slogan de Margaret Thatcher "Não Há Nenhuma Alternativa" (TINA), que declarou obsoletas todas as variantes de keynesianismo social e revivificou as crenças de início do século xx "na magia" de mercados supostamente autorregulados (Arrighi e Zhang, 2011).

Mais remotamente, as origens do neoliberalismo são diversas, mas não queremos deixar de assinalar Walter Lippman, jornalista, publicista e teórico social do início do século xx, como uma das suas fontes. Lippmann, embora tivesse começado por ser favorável ao New Deal que ao seu tempo aparecera na América, viria posteriormente a identificá-lo com a economia do estado totalitário. Associando coletivismo e totalitarismo, dizia que "nas suas formas de pensamento, os intelectuais que expõem o que agora passa por "liberalismo», 
"progressivismo", ou "radicalismo" são quase todos coletivistas no seu conceito da economia, autoritários no seu conceito do estado, totalitários no seu conceito de sociedade" (Lippmann, 1937: 49). O verdadeiro liberalismo, afirmou em The Good Society, deve insistir em dois mecanismos sociais ameaçados pela ordem coletivista - o mercado livre e a Lei. Opondo-se a todas a todas as formas de coletivismo, Lippmann afirmou que

"a filosofia liberal é baseada na convicção que, salvo em emergências e com objetivos militares, a divisão do trabalho não pode ser regulada com sucesso pela autoridade coerciva, seja ela pública ou privada, que o modo da produção que a humanidade em geral começou a adotar há cerca de cento e cinquenta anos é, na sua essência, uma economia de mercado, e que, por isso, a verdadeira linha do progresso não é prejudicar ou abolir o mercado, mas mantê-lo e melhorá-lo" (Lippmann, 1937: 175).

A sua mensagem principal era, portanto, uma afirmação do princípio da superioridade da economia de mercado relativamente à intervenção estatal.

Pouco tempo após a publicação de The Good Society, um pequeno grupo de liberais (incluindo Raymond Aron, Friedrich August von Hayek, Ludwig von Mises, Michael Polanyi), convidados pelo filósofo francês Louis Rougier, encontraram-se em Paris para discutir este mesmo livro de Walter Lippmann, dando origem a um trabalho de ressistematização do conceito de neoliberalismo (Plehwe e Walpen, 2006).

Desde então, as políticas económicas às quais o neoliberalismo se associa são bem conhecidas e são facilmente enumeradas, por exemplo na ortodoxia que emergiu nos anos 1980 e anos 1990. Vieram a ser conhecidas na frase do economista John Williamson como o "consenso de Washington": forte disciplina fiscal, reduções da despesa pública, reforma fiscal para estimular investidores de mercado, taxas de juro determinadas pelos mercados e não pelo Estado, taxas de câmbio competitivas, liberalização comercial, o encorajamento do investimento direto estrangeiro, privatização de serviços e ativos públicos, desregulação dos mercados financeiros e manutenção de direitos privados (Williamson, 2008). A estes focos esteve subjacente a visão de que é o fracasso do governo, não dos mercados, que impede o desenvolvimento e que, por isso, são os mercados e 
não os Estados que devem desempenhar o papel central no desenvolvimento económico, nomeadamente por uma "terapia de choque" (Klein, 2007) ${ }^{105}$.

Sob a influência conjunta da crise das dívidas externas e das instituições de Bretton Woods, este Consenso de Washington, que acentua a privatização, a desregulação e a liberalização do comércio, foi abraçado pelos governantes na América Latina e na Europa Oriental pós-socialista, tendo tido uma receção mais cautelosa em África e na Ásia, ainda que, também aí, as políticas tivessem assumido um impulso decidido em direcção aos mercados. O papel atribuído ao governo nestas reformas não foi além da manutenção da estabilidade macroeconómica e do papel de fornecer a educação. A prioridade, nesta linha de pensamento, era fazer recuar o Estado, não torná-lo mais eficaz.

Mas, como já vimos, o neoliberalismo foi também uma estrutura política adotada voluntariamente por muitos países ricos, como os EUA, o Reino Unido e, de uma forma geral, a Europa. O neoliberalismo, então, não é apenas o Consenso de Washington, mas mais vastamente o tipo de políticas que se desenvolveram internacionalmente desde o início dos anos 1980 para fazer do funcionamento do mercado a prioridade esmagadora da organização social. Dever-se-á dizer, no entanto, que ainda que todos estes referentes mais estritamente económicos que acabámos de referir capturem os efeitos do neoliberalismo, eles também o reduzem a um conjunto de políticas económicas com consequências políticas e

105 Um desenvolvimento-chave na história do neoliberalismo foi a eleição de Salvador Allende como presidente do Chile em 1970, a sua morte no golpe de estado e a ascensão de Augusto Pinochet, que deu oportunidade a um grupo de académicos de Chicago (os chamados "Chicago Boys") que, entretanto, tinham voltado para o Chile, para implementar as ideias neoliberais de Friedman a que, numa explicação altamente crítica, Naomi Klein chama "a doutrina de choque" (Klein 2007). A esta corresponde uma visão de que uma revisão total da economia necessitava de um choque (como o golpe chileno) e as políticas económicas deveriam ser projectadas para chocar a economia de modo a modificá-la dramaticamente e, pelo menos na teoria, insuflar-lhes a vida. A doutrina de choque, nos anos 1980, teve eco em especial nas administrações políticas conservadoras de Margaret Thatcher na Grã-Bretanha e de Ronald Reagan nos E.U. Cedo nas suas administrações, ambos empreenderam terapia de choque, por exemplo, contra os sindicados. Tais choques foram então usados como uma base de aplicação das ideias neoliberais da Escola de Chicago. Uma década depois, o colapso da União Soviética aparentemente deixou poucas alternativas ao neo-liberalismo. A maior parte do mundo veio para aceitar, ou foi coagido na aceitação, neoliberalismo. Novas forças de impulso vieram do Fundo Monetário Internacional e do Banco Mundial, que praticou uma forma de terapia de choque conhecida como 'ajuste estrutural', obrigando as nações a, para receber a ajuda destas organizações, a reestruturar as suas economias e sociedades de acordo com a teoria neoliberal. Ausente, este qualquer ideia de equidade, redistribuição, questões sociais ou o ambiente. Naomi Klein é altamente crítica destas políticas vendo o resultado das reformas associadas à terapia de choque como "a triste realidade da desigualdade, corrupção e degradação ambiental" (2007: 280). 
sociais colaterais, ignorando a racionalidade política que as organiza e que atinge outros domínios para além do mercado. Além disso, estas explicações mas economicistas obscurecem o registo especificamente político do neoliberalismo no Primeiro Mundo, isto é, a sua potente corrosão das instituições democráticas liberais em lugares como a Europa e os Estados Unidos (Brown, 2003).

Tal força corrosiva tornou-se desde logo visível nos anos 1950, quando se desenvolveu a crença de que as sociedades industrializadas eram sistemas sociais harmoniosos que não continham interiormente nenhuma força de oposição. A isto se chamou o "fim de ideologia", proclamado, de uma forma ou outra, por Raymond Aron, Seymour Martin Lipset e Daniel Bell. Este último, em particular, no seu livro O Fim da Ideologia (Bell, 1960), escreveu a partir do pressuposto de que a ideologia - descrita como a conversão das ideias em alavancas sociais - se tinha esgotado como forma de produzir ação social ou política. Em praticamente todos os países da NATO, os partidos da esquerda enfrentavam a ameaça da extinção e, face a esta suposta falência da Esquerda, as teorias conservadoras da democracia do consenso tinham ganho, sem oposição prática. A partir destes princípios conservadores, Bell assumia, assim, que a discussão sobre a ideologia como o princípio de organização de sociedade tinha terminado (1960: 47-74). Mas, na verdade, como Mills (1960) defendeu, a ideologia do fim da ideologia tornara-se ela própria, uma ideologia.

Em todo o caso, afirmando-se como discurso que veio a dominar o mundo contemporâneo (formal, prática, cultural e imaginativamente), o neoliberalismo funciona hoje com uma visão da vida económica que se impõe sobre a política, reduzindo esta à implementação do funcionamento de mercado. Neste processo de se impor sobre a política e a sociedade, evacua-se inteiramente o lugar do social na política e a regulação política da economia.

É importante referir, no entanto, que estas ideias que se disseminaram com uma extraordinária capacidade de incorporação no pensamento económico dominante, não deixaram de ter outras leituras: a ausência de imaginação e contradições do "consenso de Washington" foram expostas pelos teóricos sociais como o brasileiro Roberto Unger ou o Nobel da economia e filósofo Amartya Sen que há muito que argumenta pela reabertura da economia à ética e pela abertura dos conceitos dos economistas de racionalidade e liberdade a considerações de valor. De um modo mais geral, entre as passadas décadas de 60 
e 70, também Nicos Poulantzas e Jürgen Habermas escreveram sobre os novos problemas de legitimação que resultam do rápido crescimento e das crises nas sociedades capitalistas desenvolvidas.

De quadrantes mais próximos da política económica, outras figuras se revelaram igualmente críticas das ideias-base do consenso de Washington. Por exemplo, a ideia de que os empresários e os líderes das empresas se tornaram os heróis da democracia, tendo o mercado substituído a política como o instrumento da vontade popular ("populismo de mercado") foi exposta por Thomas Frank (2001). Os defensores de um New Deal como Joseph Stiglitz, o antigo Economista no Banco Mundial, Paul Krugman, ou o investidor multibilionário George Soros, falam hoje de um "consenso pós-Washington" (Stiglitz, 2002).

A estas vozes se juntaram outras, de dimensão coletiva: os fortes protestos relativos ao reordenamento do mundo segundo os grandes interesses empresariais e que procuram impedir o progresso da doutrina neoliberal como princípio dominante passaram a marcar presença constante na política internacional, desde os encontros da Organização Mundial do Comércio de Seattle em 1999.

Apesar destas "brechas" no discurso neoliberal, este não parece, no entanto, abalado. Como refere David Harvey,

\footnotetext{
"a existência de fendas no edifício ideológico não significa que este esteja completamente quebrado. Nem se segue que porque algo é claramente oco, as pessoas a reconhecerão imediatamente como tal. Até agora, a fé nos pressupostos subjacentes à ideologia de mercado livre não corroeu demasiado. Não há indicação que as pessoas nos países capitalistas avançados (à parte dos descontentes habituais) estejam a procurar modificações radicais do estilo de vida, embora muitos reconheçam que deveriam economizar aqui ou poupar mais ali" (Harvey, 2010: 218)
}

Além disso, como a crise portuguesa demonstra mais uma vez, o neoliberalismo reforça-se em situações de crise. Esta, no entanto, não é apenas económica e não pode ser explicada apenas neste termos. São as suas ramificações para o social e o político que exploramos de seguida. 


\section{Novos espíritos hegemónicos}

O conceito de Gramsci (1971) de "hegemonia» constitui um quadro possível para compreender a imposição do neoliberalismo na maioria das sociedades contemporâneas. Ainda que haja múltiplas interpretações neogramscinianas do neoliberalismo, parece-nos útil a de Richard Peet que escreve que, para Gramsci, "a hegemonia ideológica foi estabelecida sobretudo por instituições civis e não estatais. Nesta formulação, a hegemonia é um conceito da realidade, espalhada pelas instituições cívicas, que dá forma a valores, hábitos e ideais espirituais, induzindo, em todas as camadas de sociedade, consentimento "espontâneo" ao status quo. A hegemonia é uma visão do mundo, tão completamente difundida que se torna, quando interiorizada, senso comum" (Peet, 2003:15). Peet recorda ainda que processo de incorporar uma conceção do mundo hegemónica - "a produção sociocultural da forma como as pessoas pensam" (Peet, 2003: 17) - não é nunca completo, mas um esforço contínuo das elites para controlar a opinião pública.

Pelo seu lado, na análise que fazem do capitalismo contemporâneo Luc Boltanski e Ève Chiapello (2005) não utilizam o termo "hegemonia» e mantêm o de "ideologia", mas afirmam que "o espírito do capitalismo é precisamente o conjunto de crenças associadas à ordem capitalista que justificam esta ordem e, ao legitimá-la, mantêm as formas de ação e as predisposições que são compatíveis com ela" (Boltanski e Chiapello, 2005: 10). Acrescentam estes autores que teremos de "reconhecer que uma maioria dos envolvidos - os fortes, tanto quanto os fracos - se baseiam nesses esquemas para representar para si próprios o funcionamento, os benefícios e os constrangimentos da ordem em que se encontram imersos" (Boltanski e Chiapello, 2005: 11). O termo "espírito" (inspirado em Weber) do capitalismo refere-se, portanto, a uma ideologia que justifica o compromisso das pessoas para com ele e serviu para legitimar o capitalismo neoliberal flexível do nosso tempo, traçando um afastamento das estruturas hierárquicas fordistas em direção a modelos mais flexíveis de organização e emprego. Focando principalmente o contexto francês, estes autores veem no neoliberalismo um "espírito" totalizador que tudo deve ao facto de cada nova época do capitalismo cooptar o espírito de divergência e de desafio da época anterior. Assim, nos anos 1970 e 1980, os teóricos da gestão de empresas agiram 
como uma vanguarda neoliberal quando embeberam o espírito radical de 1968 e o venderam às massas de trabalhadores da Nova Economia.

Nesse sentido, o discurso da gestão incorporou e cooptou "a crítica artística», articulada com aparecimento, em final dos anos 60, de um novo tipo de protesto de grupo, "especialmente sensível à crítica artística do capitalismo, com as suas exigências de libertação (particularmente sexual) e uma existência e "verdadeira» (movimentos feminista, homossexual, anti-nuclear e ecológicos)" (Boltanski e Chiapello, 2005: 190). Conseguiram fazê-lo porque o neoliberalismo, embora possa servir fins ideológicos específicos, é muito mais que uma ideologia, tal como esta é tradicionalmente entendida (grupo de crenças falsas ou ilusórias). Antes, é melhor entendido como "hegemonia», uma hegemonia do mais vasto horizonte do pensamento que mantém, como aceitáveis, as desiguais distribuições dos recursos e do poder.

A transformação dos movimentos sociais nos anos 60 e a sua aliança à chamada "Nova Esquerda" produziu, com efeito, para alguns autores, uma cooptação destes ao neoliberalismo. Antes de meados dos anos 1960, os teóricos dos movimentos sociais concentraram-se na perceção comum de desigualdade económica, injustiça social e nas relações mais vasta de classe e/ou raça. Mas, desde então, observou-se que os chamados "novos movimentos sociais" mostraram uma tendência de afastamento das lutas de ideologia ou classe em direção a questões de identidade e auto-perceção.

Referindo-se a este particular aspeto, a análise que Nancy Fraser desenvolve sobre a relação do feminismo como neoliberalismo é especialmente potente e perturbadora porque não só estabelece os grandes quadros de análise para pensar esta questão, como mais particularmente foca um dos movimentos sociais que mais força teve na sua luta contra as desigualdades e as injustiças geradas pela sociedade capitalista: o feminismo. Valerá a pena, antes de mais, citar longamente como ela descreve as várias frentes de luta das feministas em finais das décadas de 1960 e 1970 contra a cultura política economicista, androcêntrica, estatista e Westfaliana do capitalismo organizado pelo Estado:

"as feministas da segunda vaga uniram-se a outros movimentos emancipatórios para romper o imaginário restritivo e economicista do capitalismo organizado pelo Estado. Politizando "o pessoal", expandiram o significado 
de justiça, reinterpretando como injustiças desigualdades sociais que tinham sido negligenciadas, toleradas ou racionalizadas desde tempos imemoráveis. Rejeitando tanto o foco exclusivo do Marxismo na economia política quanto o foco exclusivo do liberalismo na lei, desvendaram injustiças localizadas noutros lugares - na família e nas tradições culturais, na sociedade civil e na vida quotidiana. Além disso, (...) ampliaram o número de eixos que poderiam abrigar a injustiça. Rejeitando a primazia das classes, as feministas socialistas, as feministas negras e as feministas anti-imperialistas também se opuseram aos esforços das feministas radicais em situar o género na mesma posição de privilégio categorial (...). Ao fazê-lo, ampliaram efetivamente o conceito de injustiça para abranger não apenas as desigualdades económicas, mas também as hierarquias de status e as assimetrias do poder político. Numa visão retrospetiva, podemos dizer que elas substituíram uma visão de justiça monista e economicista por uma compreensão tridimensional mais ampla, abrangendo a economia, a cultura e a política." (Fraser, 2009: 103)

Fraser nota então que o neoliberalismo causou uma profunda mudança no próprio terreno que constitui a base da segunda vaga do feminismo. Com efeito,

\begin{abstract}
"a ascensão do neoliberalismo coincidiu com uma alteração na cultura política das sociedades capitalistas em que as reivindicações de justiça foram progressivamente expressas como reivindicações de reconhecimento da identidade e da diferença. Com esta mudança "da redistribuição para o reconhecimento" vieram pressões poderosas para transformar a segunda vaga do feminismo numa variante da política de identidade. Uma variante progressista, de facto, mas que tendia, contudo, a alargar excessivamente a crítica da cultura, enquanto subestimava a crítica da economia política. $\mathrm{Na}$ prática, a tendência foi para subordinar as lutas sócio-económicas a lutas pelo reconhecimento" (Idem).
\end{abstract}

Numa referência a Boltanski e Chiapello, Fraser interroga-se, portanto, se o feminismo de segunda vaga forneceu inconscientemente um ingrediente-chave do "novo espírito do capitalismo" que, por sua vez, incorporou a crítica do feminismo de segunda vaga do capitalismo estatal e "o resignificou". 
Outros fatores constituem elos de ligação entre o capitalismo e a segunda vaga do feminismo. Assim, se o "espírito do capitalismo" assenta numa narrativa masculina do indivíduo livre, na verdade as mulheres são um seu elemento central. Atraídas pela necessidade de independência económica que o capitalismo parecia oferecer, e na base de uma crítica do salário familiar, encontramos, por isso, na interface com o sistema económico, grandes frentes de mulheres: não apenas "os quadros femininos das classes médias profissionais, determinadas a quebrar os tetos de vidro", como "as trabalhadoras temporárias, de trabalho parcial, prestadoras de serviço de baixa remuneração, domésticas, trabalhadoras do sexo". Por isso, ao contrário de uma suposta emancipação que teria trazido para as mulheres, na verdade o "capitalismo desorganizado vende gato por lebre ao elaborar uma nova narrativa do avanço feminino e de justiça de género" (Fraser, 2009: 110).

Fraser não abandona algum otimismo sobre a possibilidade de uma viragem no neoliberalismo vigente, mas o mais perturbador no seu texto é o vislumbre de que mesmo a voz dissidente e emancipatória pode ser cooptada por lógicas que criamos também pela nossa própria voz e não apenas pelos nossos silêncios.

Mas, ao considerar as nefastas consequências da crise neoliberal como um aprofundamento da pobreza em geral e para os grupos que estão em maior desvantagem, talvez devamos considerar que o que está em causa não é apenas a voragem economicista das nossas reivindicações culturais, mas também uma verdadeira crise de voz, no sentido em que esta não é escutada. Ouvir, aqui, constitui-se como o ato radical de reconhecer que alguém tem algo a dizer, que é capaz de gerar outras narrativas de si mesmas/os e dos seus projetos humanos. Ouvir, neste sentido, obriga-nos a adotar perspetivas morais que garantam as condições sociais do reconhecimento e do respeito por todos os outros, pelo amor, igualdade e solidariedade (Honneth, 2007).

\section{Uma crise de voz}

E é precisamente como uma crise de voz que Nick Couldry vê o êxito incontestado da racionalidade neoliberal, onde o termo fundamental na compreensão do mundo é "mercado": o mundo social surge nesta racionalidade apenas como 
composto de mercados e de espaços de concorrência potencial, bloqueando todas as outras narrativas (Couldry, 2007). É este bloqueio de narrativas que, para este autor, se constitui como uma crise da voz. Nas suas palavras (2010: 10), "a voz é minada por racionalidades que não têm em conta a voz e por práticas que excluem a voz ou desprezam formas da sua expressão”. E essa racionalidade que impede a voz é, para Nick Couldry, precisamente o neoliberalismo, um tema que ele desenvolve extensamente no seu livro Why Voice Matters (2010).

Para Couldry, o termo "voz" constitui a ligação que interrompe a perspetiva neoliberal da vida económica, desafia a visão neoliberal da política como mercado e que nos permite construir uma perspetiva alternativa de política, que é pelo menos em parte orientada para valorizar os processos da voz, incluindo um reconhecimento da capacidade que as pessoas têm de cooperação social. A voz, como Couldry a entende, não traduz uma certa perspetiva dos processos económicos (a "voz" do consumidor) ou sequer dos mecanismos da representação política (a 'voz' política), mas constitui-se como uma explicação mais vasta do que são os seres humanos, implicando reconhecimento da sua capacidade de ação reflexiva e de reconhecimento dos outros. Nas suas palavras, a voz

"refere-se ao valor de segunda ordem da voz enraizado no processo de reconhecer mutuamente que as nossas afirmações uns aos outros como agentes humanos reflexivos, cada um com uma explicação para oferecer, uma explicação das nossas vidas que tem de ser registada e ouvida, estando as nossas histórias infinitamente emaranhadas nas histórias dos outros" (Couldry, 2009: 580)

O valor da voz articula determinados aspetos básicos da vida humana que são relevantes, sejam quais forem as nossas visões de democracia ou justiça. Por isso, permite estabelecer pontos em comum entre as estruturas contemporâneas para avaliar a organização económica, social e política e para pensar a crise contemporânea além da estrutura neoliberal.

O termo "voz", em Couldry, passa pela bem conhecida discussão de Aristóteles em a Política” onde ele distingue a mera 'voz' (phone) 'do discurso' (logos); para Aristóteles só este último é o meio de deliberação política e ação, sendo a primeira a capacidade que os seres humanos partilham com a maior parte de 
animais de comunicar sentidos básicos de dor, prazer etc.. Mas a integração moderna do mundo da vida e dos sistemas, intensificada na prática nos regimes da era dos media digitais e ideologicamente pela doutrina neoliberal, interrompe o espaço básico da voz/expressão que Aristóteles via como seguramente assumida "sob" o discurso político. Hoje, a phone ocupa quase totalmente o lugar do logos e o resultado é uma forte cacofonia que nada mais é que o ruído do silêncio.

Importa, pois, recuar no silêncio e devolver a voz à sua dimensão narrativa, como explicações de nós e do nosso lugar no mundo. Como referiu Paul Ricoeur, também citado por Couldry, "Talvez, apesar de tudo, seja necessário... acreditar que novas formas narrativas, que ainda não sabemos como denominar, já estejam a nascer". Pois, escreve ele, "não temos ideia nenhuma do que seria uma cultura onde já ninguém soubesse o que significa narrar as coisas”. (Ricoeur, 1984: 28). Tratar as pessoas como se elas não tivessem essa capacidade de narrativa é tratá-las como se elas não fossem humanas e o século passado fornece muitos exemplos vergonhosos disto mesmo.

A voz, para Nick Couldry, é uma palavra para essa capacidade, mas ter voz nunca é o suficiente. Tenho de saber que a minha voz importa; de facto, a oferta de voz é crucial à legitimidade das democracias modernas, e na vida económica e social a voz é oferecida de várias formas. No entanto, habituámo-nos a formas de organizar o mundo que ignoram a voz, que supõem que a voz não importa e desse modo negamos a nossa humanidade.

O reconhecimento disto é comum à filosofia continental (Paul Ricoeur), ao pós-estruturalismo (Judith Butler, Adriana Cavarero) e à tradição anglo-americana (Charles Taylor, Axel Honneth, Nancy Fraser), mas é nesta última que a comunicação ganha particular destaque, no seu sentido ético-moral: seja na ética discursiva habermasiana (frequentemente criticada pelo seu formalismo e proceduralismo), seja na perspetiva de Honneth onde as próprias patologias do reconhecimento possam ser o centro do diagnóstico crítico das nossas sociedades e onde "os conceitos básicos de uma análise da sociedade têm de ser construídos de modo a compreender as desordens ou défices na estrutura social do reconhecimento, enquanto que os processos de racionalização societal perdem a sua posição central" (Honneth, 2007: 74).

Também no campo da psicologia, Carol Gilligan analisou a dimensão ética do escutar do outro, na frequente dificuldade das mulheres em encontrar uma 
voz ou um reconhecimento da sua agência moral e como a forma como "numa vOZ diferente" podemos desenvolver uma ética não da justiça, mas do cuidado. Também o seu trabalho mais recente com sobre a interseção de raça, cIasse e género das jovens pobres negras ou latinas americanas permite compreender como se produz uma ausência de poder e de voz. Carol Gilligan, com Jill Taylor e Amy Sullivan, em Between Voice and Silence, seguem um grupo de raparigas adolescentes que começam a sua vida certas do seu direito de falar, mas que aprendem, à medida que crescem, que o silêncio é valorizado sobre a voz. As experiências de vida ensinam estas jovens a "aprender" a ser passivas e a não questionar. Dizem-nos as autoras: "neste livro, introduzimos uma paisagem que é estranhamente silenciosa - onde as jovens na sua maioria não são ouvidas em público, ou se são, fala-se delas, em geral, na terceira pessoa. Estas raparigas têm vozes; elas são perfeitamente capazes de falar na primeira pessoa, mas como elas dirão repetidamente, ninguém escuta, ninguém se preocupa, ninguém pergunta o que elas sentem e pensam" (Gilligan et al, 1995: 1). Fica, portanto, claro como também as intensas forças locais podem fazer com que a algumas pessoas sejam fechadas as oportunidades de falar e de ser reconhecidas positivamente no que dizem, dentro de uma mais larga distribuição social da voz que tem fortes marcas de género.

O que todos estes exemplos nos mostram é a necessidade de pensar a voz muito para além dos binários ativo-passivo dos modelos de comunicação e da receção baseados em teorias da "transmissão", tão comuns quando se pensa a comunicação humana. E é sobretudo essa desconstrução que urge fazer quando passamos ao terreno dos media.

\section{Media e reconbecimento}

Regressando a noções de hegemonia para explicarmos a imposição do neoliberalismo, não podemos deixar de recordar Gramsci para quem "a relação entre os intelectuais e o mundo da produção não é tão directa como é com os grupos sociais fundamentais mas é, de forma variável, "mediada" por todo o tecido da sociedade" (Gramsci 1971: 12). E é nessa mediação que Dieter Plehwe, Bernhard Walpen e Gisela Neunhöffer (2006) se centram para compreender o que chamam de 
"constelações neoliberais", referindo-se à ascensão sem precedentes de diversas organizações de sociedade civis implicadas nas lutas contemporâneas pela hegemonia dentro e através de fronteiras nacionais: actores privados transnacionais, como fundações, think tanks e organizações de pesquisa, media, sindicatos e igrejas desempenham um papel-chave na manutenção do status quo neoliberal. Não basta, portanto, pensar os grandes "núcleos" estatais ou empresarias para compreender a imposição de uma certa racionalidade sobre todo o tecido social e político. É preciso compreender também como ela é aceite a partir da base e da própria sociedade civil:

"As forças neoliberais são fortemente deturpadas e subestimadas se forem equacionadas com as "forças sistémicas» das elites ou classes dirigentes, ou se a reprodução do neoliberalismo "de baixo para cima» no terreno da sociedade civil não merecer atenção" (Plehwe et. al., 2006: 15-16).

A crise de voz de que fala Couldry para compreender o neoliberalismo e a situação atual encontra, portanto, alguns dos seus elos "de baixo para cima" na ligação que se faz, entre outros elementos, nos suportes que sustentam a nossa voz: os media. Estes são um elo, na verdade, extraordinariamente potente, não porque tenham efeitos imediatos e unívocos, mas porque, de modo mais subtil, são eles que se constituem como lugar privilegiado para analisar a interseção entre determinadas narrativas da crise, que hoje fazem parte do nosso quotidiano, e os processos de reconhecimento moral que necessariamente terão de estar presentes em qualquer comunicação, como vimos, se queremos que as nossas vozes tenham significado. Por isso, é também para os media que nos devemos também voltar para compreendermos a crise que vivemos.

$\mathrm{Na}$ verdade, os media desempenham um papel importante na construção das nossas compreensões, dos nossos afetos e respostas, tanto populares como governamentais, à crise (Grossberg, 2010b). Numa perspetiva cosmopolita, eles podem, nos termos de Roger Silverstone, permitir-nos ligar justiça e liberdade com "hospitalidade", no sentido de "obrigação ética de ouvir" (Silverstone, 2006: 14). Mas essa capacidade é com frequência impedida pelo facto de os media serem, eles próprios, um produto das lógicas das guerras de audiências, do apelo ao consumo e não à cidadania, atravessados por uma economia 
política neoliberal que permeia todo o seu funcionamento. Por isso, conhecemos as vozes, os argumentos, as narrativas que eles constituem diariamente e ouvimos o som do silêncio das vozes alternativas que, com raras exceções, não encontram espaço para se expressarem. Além disso, a narrativa mediática da crise - a sua velocidade, instantaneidade, produção de uma vertiginosa sucessão de eventos catastróficos que se precipitam - tende também a acentuar a articulação de vidas individuais de uma forma que exclui ou impede a possibilidade de estabelecer as ligações entre os destinos individuais e as formas mais vastas de humanidade que a todos/as nos liga. Na verdade, tais histórias são exemplos claros das imbricações dentro da vida quotidiana dos atos mediados de falar e de escutar, onde o conjunto de práticas de escuta alternativa é reprimido e interpelado por uma espécie de "empresarialização da escuta", contra as suas energias coletivas e democráticas (Lloyd, 2009). Daí, o silêncio ensurdecedor a que sistematicamente certos grupos, como as mulheres e as minorias, neles são votados, salvo quando a sua voz pode ser narrativizada em histórias singulares descontextualizadas que apelam ao sentimento e não à razão e raramente estão ligadas às narrativas maiores que lhes dão forma e das quais não podem ser destacadas.

Apesar destes fortes problemas, porém, isto não significa que os media sejam apenas os altifalantes da racionalidade neoliberal e é demasiado fácil encontrar neles mais um bode expiatório das narrativas da crise. Igualmente problemático é pensar que os processos de comunicação mediática se constituem como simples correias de transmissão de mensagens (como Walter Lippmann imaginava), geradas por uma ideologia a que não podemos escapar. Mesmo quando pensamos os mais recentes media digitais, vemos que o seu papel na arena pública não é linear ou unívoco. Por um lado, não é, de facto, possível ignorar as ligações entre o neoliberalismo e as redes digitais. Recordemos que para os seus teóricos, como Hayek, o neoliberalismo implica o triunfo das agregações de fins individuais e não de fins sociais. E de facto, ele conduziu, de várias formas, a uma forma da organização em rede na qual as pessoas não estão de modo substancial "anexadas" a grupos ou a organizações, mas a que se unem de uma maneira contingente e potencialmente frágil. Além disso, o modo como a "interatividade" é agora assumida ao nível da tomada de decisão política na sua relação com os/as cidadãs/os 
é paradigmática desta mesma fragilidade. A partir dos exemplos do Reino Unido - que podem ser estendidos possivelmente a toda a Europa -, Nick Couldry (2010) dá-nos claros exemplos do conflito entre a possibilidade de "oferecer voz" em, por exemplo, os serviços públicos - escolha interativa do/ da consumidor/a - e um rotundo fracasso em compreender o que é escutar e dar um valor mais vasto à voz, para além do puro formalismo do acesso.

E, no entanto, apesar destas preocupantes evidências, seria um erro subestimar o potencial de voz dos media ou presumir que estas novas redes, como os seus media precedentes, são apenas suportes tecnológicos a que os indivíduos se podem ligar para fins meramente consumistas.

O quadro do reconhecimento tem muitas implicações para a análise da voz, não apenas em termos do acesso aos recursos materiais (dar voz) mas em termos de justiça comunicativa, isto é, de atenção e resposta às necessidades (materiais e culturais) que avançamos. Ora, as instituições e as representações dos media são centrais aos processos de (não)dominação cultural, (não)reconhecimento e (des)respeito, bem como à constituição de recursos partilhados nas lutas pelo reconhecimento. No contexto dos media, a justiça torna-se uma questão não apenas da quantidade de tempo de antena ou acesso aos meios da produção, mas também da qualidade de relações entre oradores/as e ouvintes. Ao pensar os media em termos de reconhecimento, não basta, portanto, considerar apenas numa redistribuição material do acesso à voz. Na verdade, a política do reconhecimento sugere que uma simples redistribuição de recursos materiais da voz é inadequada, a menos que haja também uma mudança nas hierarquias de valor e respeito atribuídas a diferentes identidades e à sua produção de voz. Se, para citar Fraser, o remédio para a injustiça económica é a redistribuição, "o remédio para a injustiça cultural, pelo contrário, é algum tipo da modificação cultural ou simbólica":

"Isto pode implicar a reavaliação de identidades desrespeitadas e dos produtos culturais de grupos desvalorizados. Pode também implicar o reconhecimento e a valorização positiva da diversidade cultural. Mais radical ainda, pode implicar a transformação por atacado dos modelos sociais de representação, interpretação e comunicação de modos que poderiam modificar o sentido de si mesmo/a de todas as pessoas" (Fraser 1997: 15). 
É, portanto, na dupla componente de redistribuição material (dar vOz) e cultural (reconhecer a pluralidade de vozes, dar atenção, ouvir) que os media - velhos e novos - são elementos cruciais para a transformação do sentido do nosso self e dos nossos projetos de vida. Eles são, de facto, a mais potente plataforma capaz de cumprir o ideal de comunicação, onde a voz de muitos pode constituir um horizonte comum de interpretação, dentro da qual a auto-compreensão de nós mesmos/as como comunidade política e não apenas económica re-imaginada pode ser disputada publicamente. Nessa perspetiva, e para além das suas hierarquias de valor das notícias, entretenimento, interesse e credibilidade, os media não serão simples polos de um processo de comunicação que envolve emissores e recetores assimétricos no seu poder de produzir discursos ou de constituir uma audiência, mas uma parte indissociável da comunicação comum, baseada no reconhecimento do valor mútuo das vidas que quotidianamente narramos pela nossa voz viva e/ou mediada. Assim, um dos focos prioritários da nossa análise da crise neoliberal terá de ser, não apenas o dos ruídos da crise, mas o som dos silêncios mediáticos.

\section{BIBLIOGRAFIA}

Arrighi, Giovanni e Lu Zhang (2011), "Beyond the Washington Consensus: A New Bandung?" In Jon Shefner and Patricia Fernández-Kelly (editors), Globalization and Beyond: New Examinations of Global Power and its Alternatives, Philadelphia, PA: Pennsylvania State University Press.

Bell, D. (1960), The end of ideology. Glencoe, IL: Free Press

Boltanski, Luc, Chiapello, Ève (2005), The New Spirit of Capitalism, London: Verso

Brown, W. (2003), "Neo-liberalism and the end of liberal democracy", Theory and Event, 7(1): $4-25$

Campbell, John L., and Pederson, Ove K., eds. (2001), The Rise of Neoliberalism and Institutional Analysis. Princeton: Princeton University Press.

Cavanagh, John, and Robin Broad (2007), "Washington Consensus." In Ian Aart Schölte and Roland Robertson, eds., Encyclopedia of Globalization. New York: MTM Publishing

Couldry, Nick (2009), "Rethinking the politics of voice", Continuum, 23: 4, 579-582

Couldry, Nick (2010), Why Voice Matters: Culture and Politics After Neoliberalism. London: Sage Publications 
Cox, Robert (1996/1991), "The Global Political Economy and Social Choice", in R.W. Cox and T. J. Sinclair, Approaches to World Order, Cambridge: Cambridge University Press

Frank, T. (2001), One Market Under God, London: Secker \& Warburg

Fraser, N. (1997), "From Redistribution to Recognition?" in Justice Interruptus: Critical Reflections on the "Postsocialist" Condition. London: Routledge, pp. 11-40

Fraser, N. (2009), "Feminism, Capitalism and the Cunning of History", New Left Review 56, pp. $97-117$

Gramsci, Antonio (1971), Selections from the Prison Notebooks, New York: International Publishers.

Grossberg, Lawrence (2010a), "Modernity and commensuration: A reading of a contemporary (economic) crisis". Cultural Studies, 24: 295-332.

Grossberg, Lawrence (2010b), "Standing on a Bridge: Rescuing Economies From Economists”, Journal of Communication Inquiry, 34(4): 316-336

Harvey, David (2010), The Enigma of Capital and the Crises of Capitalism, London: Profile Books

Klein, Naomi (2007), The Shock Doctrine: The Rise of Disaster Capitalism. New York: Metropolitan Books.

Lloyd, Justine (2009), "The listening cure", Continuum, 23: 4, 477-487

Mills, C.Wright (1960), "Letter to the New Left." In Power, Politics and People: The Collected Essays of C.Wright Mills, ed. I. L. Horowitz, New York: Oxford University Press, pp. 247-259

Peet R (2003), Unholy Trinity: The IMF, World Bank and WTO. London: Zed Books

Plehwe, Dieter e Bernhard Walpen (2006), "Between network and complex organization. The making of neoliberal knowledge and hegemony", In, Plebwe, Dieter, Bernhard Walpen Gisela Neunhöffer, (eds.), Neoliberal Hegemony: A Global Critique. London: Routledge, pp. 27-50

Plehwe, Dieter, Bernhard Walpen e Gisela Neunhöffer (2006), "Introduction: Reconsidering neoliberal hegemony", In Plehwe, Dieter, Bernhard Walpen e Gisela Neunböffer, (eds.), Neoliberal Hegemony: A Global Critique. London: Routledge, pp. 1-24

Ricouer, P. (1984), Time and Narrative/Temps et Recits, Vol II. The University of Chicago Press: Chicago

Silverstone, R. (2006), Media and Morality: On the Rise of the Mediapolis. Cambridge: Polity

Stiglitz, Joseph E. (2002), Globalisation \& Its Discontents, Norton: New York

Taylor, J. M., Gilligan, C., \& Sullivan, A. M. (1995), Between voice and silence: Women and girls, race and relationship. Cambridge, MA: Harvard University Press.

Williamson, John (2008), "A Short History of the Washington Consensus" in Serra, Narcis e Joseph E. Stiglitz (eds), The Washington Consensus Reconsidered. Towards a New Global Governance, New York: Oxford University Press

Zizek, S. (2009), First as tragedy, then as farce. London: Verso. 
Carlos Camponez

FLUC - CEIS20

\section{Jornalismo: o FRACASSO DE UM CONTRAPODER ENTRE PODERES}

O jornalista, investigador e escritor espanhol, Manuel Vázquez Montalban, num importante relatório sobre a informação em Espanha, afirmava que o poder dos jornalistas é a triste história da virgem que acabou no prostíbulo (Montalban, 2008: 229).

Face à evolução que os media e o jornalismo sofreram, de forma particular nas últimas décadas, e as consequências que isso poderá ter no espaço público contemporâneo, consideramos que as palavras de Manuel Vászquez Montalban não devem ser entendidas como uma mera provocação.

No presente artigo, propomo-nos debater algumas questões que se relacionam com a crise socioprofissional dos jornalistas e perceber que autonomia podem eles reivindicar face à transformação das áreas do saber, da informação e do conhecimento no quadro das transformações dos denominados Capitalismo Intangível, Cognitivo ou Novo Capitalismo ${ }^{106}$, para recuperar conceitos de autores

106 A leitura acerca das transformações operadas pela sociedade da informação está longe de se aproximar de um consenso, nomeadamente quanto à questão de se saber se os novos conceitos reflectem novas realidades ou se essas realidades não são mais do que a expressão de mudanças de superfície, que resultam da própria capacidade da estrutura profunda do capitalismo se adaptar às novas situações, mantendo a sua natureza intrínseca. Este é um tema recorrente no livro de Kumar, Da Sociedade Pós-Industrial à Sociedade Pós-Moderna, onde o autor admite que as novas tecnologias e, em particular, os media são instrumentos de criação de novas formas de sociabilidade, embora considere que isso não nos pode levar, com inteira segurança, a falar de uma sociedade de informação com a mesma propriedade com que falamos da Revolução Industrial. Por isso, alguns autores preferem expressões como novo capitalismo, capitalismo cognitivo, capitalismo intangível, que vincam a permanência de uma mesma estrutura económica e social, do que termos como sociedade da informação ou sociedade pós-moderna, que tendem a encobrir a sua natureza e os seus fundamentos capitalistas (K. KUMAR, 1997: 172). Na mesma linha de pensamento, e numa crítica às teses de Manuel Castells, Nicholas Garnham questiona se as transformações da denominada sociedade da informação são suficientemente novas para justificarem a afirmação de que entrámos numa nova era: a era do capitalismo informacional, da sociedade em rede ou da informação (GARNHAM, 2000: 57). 
como Andrè Gorz, Jeremy Rifkin e Richard Sennett, cujas reflexões seguiremos neste artigo de uma forma particular.

Procuraremos, assim, refletir sobre algumas transformações contemporâneas da profissão e defenderemos que, contrariamente ao que faziam prever as próprias teorias sobre a sociedade da informação, os jornalistas e os profissionais da comunicação não escapam ao processo de desprofissionalização verificado em outros domínios.

\section{Da «Jaula de Ferro» à perda da autorrealização dos sujeitos}

Para Jeremy Rifkin, o capitalismo contemporâneo caracteriza-se pela redução do carácter físico da sua economia. Se a "era industrial» do Capitalismo estava marcada pela acumulação de capital e pela detenção da propriedade física, na "nova era» valorizam-se as formas intangíveis de poder (Rifkin, 2002: 137).

O capitalismo imaterial procura o controlo da dimensão simbólica, cujo alcance já não se limita aos aspetos económicos e comerciais, mas estende-se também à política e à cultura (Gorz, 2003: 62). Na perspetiva de César Bolaño, ao penetrar as áreas da cultura, o capital transforma-se, ele próprio, em cultura, no sentido mais amplo do termo, e a forma de mercadoria passa a monopolizar o conjunto das relações sociais, inclusive as mais interiores do mundo da vida e também as mais resistentes à extensão e à apropriação pela lógica capitalista (Bolaño, 2001: 81).

De acordo com Richard Sennett, o novo capitalismo alterou substancialmente as estruturas em que assentava o capitalismo social dos finais do séc. XIX. O conceito de capitalismo social relaciona-se com a noção de racionalização da vida institucional e da sociedade civil, inspiradas originalmente no modelo militar, e que foi levado a cabo na Alemanha por Otto von Bismarck. Max Weber vira neste processo de racionalização da sociedade a criação de uma «jaula de ferro», onde o sujeito estaria completamente despojado de si, face ao poder da burocratização das sociedades modernas. No entanto, segundo Sennett, os objetivos de Bismarck eram os de fundar um capitalismo capaz de garantir a paz social. Deste modo, esse capitalismo social permitiu conter a parte selvagem do "capitalismo "primitivo"» e, por isso mesmo, também estancar os ingredientes revolucionários que estavam na sua própria natureza (Sennett, 2006: 23-24). 
É certo que a burocracia impôs a funcionalização dos sujeitos, em detrimento do reconhecimento da especificidade de cada uma das suas histórias de vida, de modo a assegurar a autoconservação do sistema e a estabilidade institucional (Sennett, 2006: 34). No entanto, apesar da rigidez deste modelo militar hierarquizado, ele permitiu também a racionalização do tempo, não apenas ao nível institucional através da adoção do pensamento estratégico, como também ao nível das carreiras individuais e mecanismos de auto-compreensão dos sujeitos no interior da sociedade. Em função disso, muitos trabalhadores puderam planificar, pela primeira vez, não obstante as contingências de percurso, a compra da sua casa e ter algum controlo sobre o seu plano de realização individual (Sennett, 2006: 26). Por isso, Sennett considera que Weber exagerou na sua visão acerca da sociedade burocratizada, encerrada na jaula de ferro, não percebendo que mesmo as estruturas rígidas e burocráticas como as militares dão um espaço amplo de poder de interpretação das decisões superiores: "todos obedecem, mas todos interpretam" pelo que a ideia da "militarização da sociedade», não pode ser vista como um processo rígido de transformação dos indivíduos numa massa cega, subordinada e obediente de trabalhadores (Sennett, 2006: 34).

Esta perspetiva serve de base de partida a uma interrogação que nos interpela sobre se as liberdades subjacentes às propostas de flexibilidade e de mudança preconizadas pelo novo capitalismo serão uma verdadeira alternativa às ameaças da "jaula de ferro» sob o mundo do trabalho.

As mudanças operadas pelo novo capitalismo iniciaram-se no início dos anos 70 e são, numa abordagem sintética, consequências das novas exigências do denominado capital impaciente, resultante da ordem económica que emergiu do fim dos acordos de Bretton Woods. Pelo efeito combinado dos investimentos disponíveis e a exigência de lucros rápidos, a nova ordem económica mundial que daí emergiu, provocou mudanças aceleradas nas instituições, obrigando-as a ajustarem-se às formas organizativas mais flexíveis e menos estáveis, consideradas mais atrativas à reprodução dos investimentos e às exigências dos novos acionistas (Sennett, 2006: 39-40). Estas mudanças foram ainda potenciadas pelo desenvolvimento das tecnologias da comunicação que permitiram um maior acesso à informação, uma maior rapidez nas tomadas de decisão, bem como uma nova centralização do poder interior das organizações (Sennett, 2006: 42). 
Os processos de reengenharia ${ }^{107}$ - associados à flexibilidade, ao aumento da concorrência no interior das empresas -, bem como a precarização do trabalho, a diminuição dos níveis hierárquicos e a desvinculação das responsabilidades sociais das organizações relativamente aos trabalhadores afetaram o prestígio moral da atividade laboral. Deste modo, alteraram-se igualmente elementos chave de uma certa ética do trabalho, assente numa possibilidade de reconhecimento das capacidades dos trabalhadores, na sua experiência e comprometendo a hipótese de os indivíduos planificarem e investirem nas suas carreiras profissionais.

A ética do trabalho é um elemento que permite a Sennett distinguir dois modelos de trabalhador: o artesão e o trabalhador flexível do novo capitalismo. O primeiro rege-se pelo princípio de «fazer algo bem pelo simples facto de o fazer bem», pelo aperfeiçoamento, e é incompatível com instituições que pretendem que se faça muitas coisas diferentes e rapidamente. Já o segundo obedece a um perfil de trabalho a curto prazo, com tarefas em mudança constante onde não há lugar nem tempo para o exercício apurado das suas funções e do seu saber. Sennett dá como exemplo a investigação realizada por ele junto de um grupo de programadores informáticos que lamentavam o facto de estarem numa grande empresa de software que tinha como política distribuir material imperfeito ao público, que ia sendo corrigido em função das queixas e reclamações dos consumidores (Sennett, 2006: 92 a 94). Ora, flexibilidade e a superficialidade do trabalho impossibilitam a construção por parte dos sujeitos da sua própria narrativa enquanto autorrealização (Sennett, 2000: 30).

Neste sentido, pode-se dizer-se que as promessas efetuadas pelo novo capitalismo em relação às esperanças libertadoras contidas no virar de página da era da «jaula de ferro» limitaram-se a diminuir a componente social, mantendo incólume o essencial da natureza própria do capitalismo, mas agora desvalorizando a dimensão moral do trabalho e retomando o espectro dos trabalhadores qualificados de reserva. De alguma forma, poder-nos-íamos questionar se o

\footnotetext{
107 A reengenharia, tal como a definem Michael Hammer e James Champy, é o "repensar fundamental e a redefinição radical dos processos empresariais que visa alcançar medidas drásticas nos indicadores de desempenho críticos e contemporâneos, tais como custos, qualidade, nível de serviço e rapidez" (Hammer e Champy, s.d., p. 44.].
} 
fim deste capitalismo social não representa uma certa revisitação do capitalismo primitivo, a que se referia atrás Richard Sennett.

Com efeito, como demonstra Jeremy Rifkin, enquanto a primeira onda da automatização afetou os trabalhadores de colarinho azul, a revolução das novas tecnologias, associada ao conceito, incidiu sobre os colarinhos brancos, a classe média, os executivos de idade mais avançada e muitos trabalhadores assalariados com formação universitária (Rifkin, 1996: 236 e 238). A simples existência de um grande número de trabalhadores com emprego temporário, subcontratados, ou mesmo no desemprego permite a redução dos níveis salariais dos restantes empregados.

Para além disso, o alargamento deste fenómeno transformou numa mera ilusão o pressuposto ético de investimento no trabalho e na construção de uma carreira como condição base dos sujeitos poderem aceder a uma vida melhor (Rifkin, 1996: 236).

Sennett, por seu lado, considera que este processo de flexibilização colocou os trabalhadores perante a ameaça da inutilidade, provenientes essencialmente da globalização da oferta de trabalho, da automatização e da denominda gestão do envelhecimento (Sennett, 2006: 78).

Porém, as conceções sobre o novo capitalismo tendem a considerar que as profissões do intangível são aquelas que melhor se vão adaptando e resistindo à depredação do valor de trabalho. Entre essas profissões encontramos as ligadas aos setores intangíveis da informação e do conhecimento (Rifkin, 1996: 242; Sennett, 2006: 43), no domínio do denominado capital cognitivo (Gorz, 2003: 56). Apesar de estarmos perante conceitos com implicações vastas, queríamos salientar que não nos parece possível incluir nesse setor da informação e do conhecimento os jornalistas, uma vez que, como demonstraremos de seguida, o jornalismo não escapa aos fatores perturbadores da ética do trabalho trazidos pelo novo capitalismo.

\section{Os efeitos do Novo Capitalismo no Jornalismo}

O mais recente estudo de David Weaver (et al.) sobre os jornalistas norte-americanos identifica a emergência de cinco perigos que ameaçam a autonomia 
do jornalismo. Curiosamente desses cinco, quatro têm a ver diretamente com as questões postas em marcha pelo capitalismo cognitivo e pelas novas tecnologias:

1. A crescente comercialização das notícias;

2. As elevadas expectativas de lucro por parte das companhias de media;

3. A erosão da parede entre as redações e o negócio das organizações dos media;

4. Os escândalos;

5. As novas tecnologias dos media (WEAVER et al., 2007: 71-73).

Com efeito, as transformações verificadas no contexto do Novo Capitalismo estão já bem patentes no jornalismo e refletem-se em fenómenos que passaremos a analisar de seguida, como a racionalização a juvenelização, a perda de memória, a deslocalização das redações, bem como a hiperconcorrência, a desprofissionalização e a precariedade.

\subsection{Racionalização}

Os efeitos da racionalização impostos pelo novo capitalismo iniciam-se nos anos 70, com a informatização, embora só venha a sentir-se nas salas de redação na década seguinte, a exemplo do que aconteceu também com o interesse do "capital impaciente», em busca de investimentos de elevada rentabilidade, nas empresas de comunicação, norte-americanas. Como sublinha Ramón Zallo, a informatização das redações faz parte de um processo mais vasto que tornou o jornalista mais especializado, sem com isso estarmos perante uma efetiva melhoria da sua qualificação (Zallo, 2002: 90). Muito pelo contrário. Os jornalistas estão confrontados com uma maior concentração das capacidades de decisão nas funções de direção, chefias de secção e de redação (Zallo, 1988: 117), reduzindo a sua autonomia, mas também com exigências de maior produtividade de conteúdos, uma estrita organização temporal do trabalho, uma maior especialização e uma abundância de informação institucionalizada, relegando para um segundo plano o papel atribuído aos repórteres. De uma forma geral, a racionalização das empresas de comunicação, gerou novas pressões sobre a liberdade de criação do trabalho intelectual e aspetos relacionados com 
os direitos de autor ou a cláusula de consciência dos jornalistas, favorecendo a comercialização dos conteúdos (Zallo, 2002: 89-90).

\subsection{Hiperconcorrência e «jornalismo de comunicação»}

Como referem os investigadores canadianos Jean Charron e Jean Bonville o aumento da concorrência no setor dos media, associado às novas condições tecnológicas existentes na produção e receção de mensagens, conduziu a um jornalismo de biperconcorrência ${ }^{108}$, em que a competição, no campo jornalístico, deixou de se fazer apenas no plano das empresas - como acontecia desde o fim do séc. Xıx - para se alargar ao próprio campo profissional de produção de mensagens. Para Philip Meyer, face à quantidade de mensagens disponíveis, o problema agora é o de manter a atenção do público, recorrendo quer à segmentação e especialização dos temas, quer à confusão de géneros e à acentuação das funções expressivas e fácticas no discurso dos media (Meyer, 2007; 19 e 242-243).

Este contexto promove uma amálgama cada vez maior entre informação, entretenimento e publicidade e contribui para a diluição do muro existente entre o setor da redação e o da publicidade ${ }^{109}$. São disso expressão o aparecimento de géneros híbridos como a publirreportagem, o infoentertenimento e outros conteúdos redacionais subjugados a objetivos estritamente comerciais.

\subsection{Desprofissionalização}

Como salienta Sara Meireles, perante este «jornalismo de reclame», os jornalistas enfrentam o esbatimento das fronteiras profissionais entre, por um lado, «um mediador de estatuto menorizado, que as empresas exigem sobretudo polivalente e

108 Segundo a definição dos autores, "hiperconcorrência designa o jogo concorrencial muito particular que caracteriza os sectores assentes nas tecnologias da informação, particularmente os da informática e o das telecomunicações, e que têm de comum fundar a sua estratégia no crescimento e na inovação" (Charron e Bonville: 2004; 292-293).

109 Um dos casos conhecidos é a experiência levada a cabo pelo Los Angeles Times, cuja administração se propôs utilizar uma «bazuca para destruir o tradicional muro entre a secção de publicidade e a redação» (Apud Mesquita, 1998: 66-67). 
maleável aos seus objetivos comerciais» e, por outro lado, um operário técnico, mais próximo da execução do que da criação (Meireles, 2005; 1225 e 1228).

Este aspeto parece-nos bem patente na mitificação promovida pelo próprio jornalismo em torno da ideia do jornalista cidadão. O jornalismo praticado "por todos", tal como no-lo apresenta Dan Gillmor (2005), é de facto a expressão última da desprofissionalização e o relegar do jornalismo para o papel de mero provedor ou sinalizador de conteúdos disponíveis. Estes desenvolvimenos não deixam de dar razão a autores como Martínez Albertos quando prognostica que o jornalismo, tal como ainda hoje o vamos pensando, se extinguirá por volta do no ano 2020, quando ele não for mais do que um serviço de fornecimento de conteúdos (Albertos, 1977: 56).

\section{4. "Juvenelização» e perda de memória}

O denominado rejuvenescimento ou «juvenilização» ${ }^{110}$ da classe dos jornalistas ${ }^{111}$ é outro dos sintomas da crise no jornalismo que deve ser pensado muito para além de uma luta de gerações pelo emprego. Jornalistas mais idosos, normalmente com remunerações mais elevadas, são tradicionalmente aqueles que oferecem mais resistência às ordens superiores e à racionalização das redações. Estes dois factos tornam-nos num dos alvos principais da gestão empresarial sempre que objetivos de ordem financeira ou comercial impõem medidas de reestruturação das redações (Charron e Bonville, 2004: 304). A evolução da profissão dos jornalistas, em Portugal, verificada nos primeiros anos do séc. xxi, ficou marcada por tentativas de reduzir as redações e torná-las mais baratas, através de despedimentos e rescisões de jornalistas mais antigos e experientes e o recurso ao trabalho de outros mais jovens ou até de estagiários (Fidalgo, 2008: 111). A nossa preocupação com a juvenilização das redações não tem a ver com um conflito de

110 Para José Luís Garcia o movimento de rejuvenescimento é também acompanhado por uma diminuição geral da antiguidade dos jornalistas na profissão, podendo falar-se, nessa aceção, em «uvenilização» (GARCIA, 1994: 69).

111 Sobre o caso português veja-se GARCIA, 2009; GARCIA, 1994; GARCIA e CASTRO, 1994; Meireles, 2007, (nomeadamente Anexos); SILVA, "Jornalistas portugueses: elementos sociográficos", in URL: http://bocc.ubi.pt/pag/silva-pedro-alcantara-jornalistas-portugueses.html\# ftn1 (30/08/2011). 
gerações, mas antes com a perda de uma certa memória necessária para garantir a mise en perspective, essencial para assegurar a qualidade da informação.

\subsection{Deslocalização}

Tradicionalmente, a comunicação é considerada uma das áreas onde a globalização exige, como contraponto, uma forte componente de contextualização da informação, através de mediadores capazes de traduzirem a diversidade de mensagens que circulam no mundo inteiro para os ambientes culturais onde se inserem (Wolton, 1999: 245). Se nos ativermos às palavras de Dominique Wolton, em termos comunicativos, a deslocalização das redações é um contrasenso. No entanto, esta perspetiva esquece que a globalização é, ela própria, geradora de informação e de cultura global, bem como de processos de produção correspondentes, razão pela qual já assistimos a centros produtores de notícias a deslocalizarem os seus serviços para várias regiões da Ásia, com mão de obra e "cérebros" mais baratos, como aconteceu já com serviços da Reuters, do Chicago Tribune, do Columbus Dispatch e da BBC World.

\subsection{Precariedade}

A concentração das empresas é considerada, indiretamente, como uma ameaça à liberdade de emprego (Correia, 2006: 39). Com efeito, a concentração dos media em poucos proprietários diminui as possibilidades de mobilidade e de emprego. Segundo o Sindicato dos Jornalistas portugueses, os grupos de media funcionam como «verdadeiros cartéis de mão de obra jornalística, empregando a maior parte dos profissionais e ditando as regras do seu futuro profissional» e detêm "condições objetivas para limitar e condicionar a liberdade de expressão e a liberdade de emprego» (SINDICATO DOS JORNALISTAS, 2003). Estas posições são reiteradas por jornalistas para quem a concentração pode fomentar a «acomodação e a subserviência»), uma vez que um jornalista que se incompatibilize com um órgão de informação pode ver "fecharem-se-lhe as portas de parte significativa das empresas do setor»(Fidalgo, 2008: 116 e 117). 
No caso português, entre 2000 e 2005, 350 jornalistas foram levados a rescindir os contratos de trabalho durante processos de reestruturação, realizados nas suas empresas. Mas só nos anos de 2009 e 2010 o número de novos pedidos de subsídio de desemprego entrados na Caixa de Providência e Abono de Família dos Jornalistas foi de 254, 78 por cento dos quais de trabalhadores provenientes de um dos grandes grupos de comunicação social portugueses (Informação Sindical, 2011: 1 a 3).

A precarização do emprego está muito bem patente na alteração que se verificou no estatuto do jornalista freelance. No passado, o freelance era a imagem mais aproximada da autonomia e do exercício independente da profissão, tal como os médicos, os advogados e os engenheiros. Geralmente, eram profissionais com uma importante experiência e reconhecimento profissional, facto que lhes permitia o exercício da profissão em outras condições, quer do ponto e vista remuneratório quer ainda do reconhecimento do seu estatuto profissional. Por isso mesmo, o estatuto de freelance estava reservado a um número relativamente reduzido de jornalistas. Hoje a maior parte destes profissionais são denominados de "falsos" freelance ou freelance "forçados», prestando as suas tarefas em condições em tudo idênticas às dos outros jornalistas assalariados. Um estudo efetuado em 2003 mostrou que ofreelance representava cerca de 20 por cento dos jornalistas da União Europeia e que a taxa de crescimento entre 1995 e 2003 foi, na generalidade, bastante mais elevada que a dos jornalistas assalariados. No caso específico da Alemanha, o crescimento do número de jornalistas freelance foi superior ao dos trabalhadores independentes dos restantes setores de atividade, revelando estarmos mesmo a assistir a uma substituição do trabalho assalariado pelo freelance, a exemplo do que parece suceder também na Suécia. Em países como a Grécia e a Hungria, o número de jornalistas freelance era já superior ao dos assalariados e, na Itália, atingia os 48 por cento da totalidade dos jornalistas, correspondendo a um crescimento de 90 por cento entre 1998 e 2002 (Nies e Pedersini, 2003).

Como referem Blumler e Gurevitch, a diminuição e precarização do emprego, bem como o aumento dos aspetos concorrenciais dentro dos próprios media são fatores considerados determinantes do enfraquecimento do estatuto e da autonomia dos jornalistas nos últimos anos, em particular nos domínios da informação política (Blumler e Gurevitch, 1991: 159-160). 
Face a esta desqualificação dos jornalistas há já quem os equipare a operários em linha de montagem (Baptista, 2008; 36 a 39). O jornalista António Rego questiona-se mesmo se ainda existem jornalistas livres. No seu entender, não estamos perante uma mera pergunta retórica, mas uma inquietação que atinge muitos profissionais de comunicação que escrevem, dizem e filmam o que mandam os seus superiores e não aquilo que gostariam de revelar. E acrescenta:

"A fábrica em que trabalham, pública ou privada, tem regras, objetivos, métodos, que utiliza o jornalismo para um fim que não é o de informar, formar ou divertir. É um instrumento de poder, fatia de um grande queijo que funciona como artefacto de lucro ou aparelho de propaganda, que precisa de bons profissionais que tornem o produto apetecível, vendável ou politicamente persuasivo. Está em laboração contínua na corrida ao primeiro lugar, à liderança, ao domínio do mercado ou ao peso da influência, com capacidade de comunicação, resposta pronta, antecipação arrojada. É um campo de batalha a informar, a cultivar, a divertir» (REGO, 2008: 5).

\section{Uma desregulação ética do trabalho}

Este diagnóstico afeta profundamente as bases da ética do trabalho no jornalismo e a situação não nos parece muito diferente daquela efetuada por Sennett noutras áreas do trabalho face às mudanças provocadas pelo novo capitalismo.

Talvez devêssemos questionar se também ao nível de profissões ditas ordenadas como os médicos, os advogados, os arquitetos - para já não falar dos professores universitários -, não se farão já sentir muitos destes fatores de desprofissionalização e perda de autonomia. Essa discussão levar-nos-ia muito longe. Limitar-nos-emos a referir que, no caso do jornalismo, essa autonomia é posta em causa por outros fatores, resultantes do facto de estarmos a falar de uma profissão aberta e sem um campo de saber específico. No estudo que realizámos sobre a autorregulação dos jornalistas portugueses, entre 1974 e 2007, verificamos que os jornalistas poucas vezes assumiram de forma consistente a defesa dos seus valores profissionais, através de uma autorregulação vigorosa, representativa e credível (Camponez, 2010). Esta situação afigura-se-nos 
particularmente grave, em particular porque compartilhamos da opinião do historiador francês Gilles Feyel segundo o qual, enquanto profissão aberta, e na ausência de um saber sistémico próprio, o único fundamento legitimador do jornalismo reside na ética (Prodhome, 2005: 62) ${ }^{112}$. Se retomássemos as teses do professor Vital Moreira sobre estas matérias, diríamos que a autonomia dos jornalistas, em Portugal, exerce-se num quadro de uma autorregulação regulada pelo Estado. Através de um processo de concluído com a legislação publicada em 2007 e 2008, sobre o Estatuto do Jornalista e a Comissão da Carteira Profissional do Jornalista, assistimos desde os anos 90 a um processo de captura da autorregulação dos jornalistas pelo Estado, expressão última daquilo que consideramos ser a autorregulação frustrada dos jornalistas portugueses.

\section{Conclusão}

Ao focarmos os aspetos de ordem sistémica presentes no novo capitalismo e ao sublinharmos os efeitos que isso tem na profissão dos jornalistas, não pretendemos, pois, justificar o que vai mal na autorregulação dos jornalistas, nem tão-pouco mitigar a sua responsabilidade social. Pelo contrário. A ausência de uma autorregulação vigorosa do jornalismo é um sintoma de uma crise profunda da profissão pelo que não percebemos como podem os jornalistas exercerem a sua responsabilidade, sem assumirem a autorregulação como uma das componentes essenciais da sua auto-consciência. Como afirma Mário Mesquita, não sendo um profissional liberal, o jornalista possui uma área de autonomia pelo que não é legítimo que se demita de exercê-la ou que faça de conta que não a exerce (Mesquita, 2003: 87). E «(...) quando isso acontece - sustenta por seu lado Edwin Baker -, tanto perdem os jornalistas como o público que neles confia» (Baker, 2002: 281).

112 Michel Mathien refere-se também à ética como o elemento motor do reconhecimento do estatuto dos jornalistas em França, nos anos 30 do século passado. A organização dos jornalistas numa estrutura como o Sindicato Nacional dos Jornalistas franceses parecia responder ao desiderato de uma autorregulação capaz de assegurar a independência de espírito e preservar a consciência moral dos profissionais, rejeitando aqueles que eram considerados «indignos" da profissão (Mathien, 1995: 72). 
Neste sentido, à crise suscitada pelas lógicas sistémicas do novo capitalismo junta-se a crise dos valores profissionais, enquanto um espaço de valores e de recriação do jornalismo. Sem pensamento crítico, sem regresso, sem capacidade de se pensar não há causa que valha a pena e o jornalismo enfrenta a mais séria ameaça de subtração do seu próprio futuro.

Com efeito, estamos em crer, pelo fenómeno de convergência e concentração que assistimos nos media em todo o mundo, que o novo capitalismo, e o capitalismo intangivel tornarão o jornalismo mais lucrativo, mas o desafio que se nos coloca é saber se com isso a democracia ficará mais rica. 


\section{BIBLIOGRAFIA}

BAKER, C. Edwin (2002), Media, Markets and Democracy, Cambridge, Cambridge University Press.

BAPTISTA, Carla (2008), "O jornalismo faz mal à saúde», Jornalismo e Jornalistas, n. . 34, Abril/Junho.

BLUMLER, Jay G., e GUREVITCH, Michael (1991), "Rethinking the study of political communication", in CURRAN, James e GUREVITCH, Michael (orgs.), Mass Media and Society, Londres, Edward Arnold.

BOLAÑO, César Ricardo Siqueira (2001), «Trabajo intelectual, comunicación y capitalismo - La reconfiguración del factor subjetivo en la actual reestructuración productivan, in FERNÁNDEZ, Fenando Queirós, e CABALLERO, Francisco Sierra (dirs.), Comunicación, Glogalización y Democracia - Crítica de la economía política de la comunicación y la cultura, Sevilha, Comunicación Social.

CAMPONEZ, Carlos (2010), Fundamentos de Deontologia do Jornalismo - A auto-regulação fristrada dos jornalistas portugueses (1974-2007), Coimbra, Almedina.

CORREIA, Fernando (2006), Jornalismo, Grupos Económicos e Democracia, Lisboa, Caminho.

CHARRON, Jean, e BONVILLE, Jean (2004), «Le Journalisme et le marché: de la concurrence à l'hiperconcorrence», in BRIN, Colette, CHARRON, Jean, e BONVILLE, Jean, Nature et Transformation du Journalisme - Théorie et recherches empiriques, s.l., Les Presses Universitaires de Laval.

FIDALGO, Joaquim (2008), "Os novos desafios a um velho ofício ou... um novo ofício? A redefinição da profissão de jornalista", in PINTO, Manuel, e MARINHO, Sandra, Os Media em Portugal nos Primeiros Cinco Anos do Século XXI, Porto, Campo das Letras.

GARCIA, José Luís (2009) (org.), Os Jornalistas Portugueses - Metamorfoses e encruzilhadas no limiar do séc. XXI, Lisboa, ICS.

GARCIA, José Luís e CASTRO, José (1994), «Recomposição social e estratégias profissionais", in Jornalista Português O Que É? - Inquérito e perfil sócio-profissional, s.l., Sindicato dos Jornalistas.

GARCIA, José Luís (1994) «Principais Tendências de Evolução do Universo dos Jornalistas Portugueses", Vértice, Maio-Junho, n. ${ }^{\circ}$ 60, 2a Série.

GARNHAM, Nicholas (2000), «La théorie de la société de l'information en tant qu'idéologie», Réseaux, n. ${ }^{\circ} 101$.

GILlMOR, Dan (2005), Nós os Media, Lisboa, Presença.

GORZ, André (2003), L'Immatériel - Connaissance, valeur et capital, Paris, Galilée.

HAMMER, Michel, e CHAMPY, James (s.d.), A Reengenharia da Empresa - Em função dos clientes, da concorrência e das grandes mudanças da gerência, Lisboa, Dinalivro.

KUMAR, Krishan (1997), Da Sociedade Pós-Industrial à Pós-Moderna - Novas teorias sobre o mundo contemporâneo, Rio de Janeiro, Jorge Zahar Editor. 
MATHIEN, Michel (1977), Les Journalistes, Paris, Presses Universitaires de France, 1995.

ALBERTOS Martínez, José Luíz (1997), El Ocaso del Periodismo, Barcelona, CIMS.

NIES, Gerd, e PEDERSINI, Roberto (2003), Les Journalistes Free-Lances dans l'Industrie Médiatique Européenne, FEJ/Commission Européenne, Outubro.

MEIRELES, Sara (2005), "As mutações do jornalismo profissional no novo ambiente dos mass media", in AAVV, Livro de Actas - IV. ${ }^{\circ}$ SOPCOM, in URL: http://www.bocc.ubi. $\mathrm{pt} / \mathrm{pag} / \mathrm{graca}-\mathrm{sara}$-mutacoes-jornalismo-profissional-novo-ambiente-mass-media. pdf, (consultado em 30/08/2011).

MEIRELES, Sara (2007), Os Jornalistas Portugueses - Dos problemas aos novos dilemas profissionais, Coimbra, MinervaCoimbra.

MESQUITA, Mário (1998), Jornalismo em Análise - A coluna do provedor dos leitores, Coimbra, Minerva.

MESQUITA, Mário (2003), O Quarto Equívoco - O poder dos media na sociedade contemporânea, Coimbra, MinervaCoimbra.

MONTALBAN, Manuel Vázquez (2008), Informe Sobre la Información, Barcelona, Valentín Roma.

PRODHOME, Magali (2005), La Place du Discours sur l'Éthique dans la Construction de l'Espace et de l'Identité Professionnels des Journalistes, Clermont-Ferrand, Presses Universitaires de la Faculté de Droit de Clermont-Ferrand.

REGO, António (2008), "Haverá jornalistas livres», Agência Ecclesia ("Igreja e Media - Em busca de novas sintonias»), n. ${ }^{\circ} 1145,29$ de Abril.

RIFKIN, Jeremy (1996), El Fin del Trabajo - Nuevas tecnologías contra puestos de trabajo: el nascimiento de una nueva era, Barcelona, Buenos Aires, México, Paidós.

RIFKIN, Jeremy (2002), La Era del Acceso - La revolución de la nueva economía, Barcelona, Buenos Aires, México, Paidós.

SENNETT, Richard (2000), La Corrosión del Carácter - Las consecuencias personales del trabajo en el nuevo capitalismo, Barcelona, Editorial Anagrama.

SENNETT, Richard (2006), La Cultura del Nuevo Capitalismo, Barcelona, Editorial Anagrama.

SENNETT, Richard (2003), Respect - De la dignité de l'homme dans un monde d'inégalité, s.l., Hachette Littératures.

SILVA, Pedro Alcântara da, "Jornalistas portugueses: elementos sociográficos», in URL: http://bocc.ubi.pt/pag/silva-pedro-alcantara-jornalistas-portugueses.html\#_ftn1 (consultado em 20/12/2008).

SINDICATO DOS JORNALISTAS, «Por Uma Agenda dos Poderes Públicos para os Media - Contributo do Sindicato dos Jornalistas", 5 de Setembro, 2003, in URL: http://www. jornalistas.online.pt $/$ noticia.asp? $\mathrm{id}=1352 \&$ idselect $=377 \&$ idCanal $=377 \& \mathrm{p}=0 \quad$ (consultado em 30/08/2011).

SINDICATO DOS JORNALISTAS (2011), "Desemprego volta a penalizar em 2010 - Grupos "concentram" 78\% dos jornalistas despedidos", s.l., Informação Sindical, n. ${ }^{\circ}$ 1, 20 de Janeiro. 
WEAVER, David H., BEAM, Randal A., BROWNLEE, Bonnie J., VOAKES, Paul S., e WILHOIT, Cleveland (2007), The Ameican Journalist in the 21st Century - U.S. News people at the daw of new millennium, Nova Jérsia e Londres, Lawrence Erlbaum Associates.

ZALLO, Ramón (1988), Economia de la Comunicación y la Cultura, Madrid, Akal.

ZALLO, Ramón (2002), El Mercado de la Cultura - Estructura económica y política de la comunicación, Donostia, Gakoa Liburuak. 
Ana Teresa Peixinho

FLUC - CEIS20

\section{A narrativa como Superação da CRise}

\section{Considerações prévias: a crise dos jornais de papel}

O que pretendo partilhar nesta reflexão prende-se essencialmente com um pressuposto: o de que o Jornalismo vive uma crise sem precedentes, mote que, aliás, tem sido retomado de forma insistente na última década.

O Jornalismo, enquanto atividade e área sociocultural, também não escapa, portanto, à abrangência da crise nas sociedades atuais, sendo ele um campo marcado por problemas endógenos mas também e, seguramente, por tensões externas que dilaceram o campo socioprofissional. Crise de legitimidade profissional, dramática para os jornalistas que têm de encarar despedimentos ou submissões diversas, muitas vezes violentando a sua independência e liberdade; crise de leitura, pois cada vez menos os jornais impressos são comprados e lidos; crise ético-deontológica, assistindo-se a subversões nos critérios de seleção e tratamento das notícias; crise de estratégias e práticas editoriais: estas são algumas das consequências, na nossa opinião, decorrentes da lógica de mercado selvagem que impera sobre o jornalismo, a que Carlos Camponez chama de "crise sistémica das lógicas do novo capitalismo" (Camponez, 2010), e também das mudanças rápidas provocadas pelo surgimento dos novos media que arrastam consigo novos paradigmas de construção do sentido, de escrita e de leitura, tema desenvolvido na conferência do Professor António Fidalgo publicada neste volume.

Na sua lição para Provas de Agregação, Manuel Pinto faz uma radiografia bastante bem circunstanciada das múltiplas crises que atravessam o campo jornalístico na atualidade, explicando como a formação de grandes oligopólios mediáticos e a ditadura da rentabilização que preside à lógica de mercado tiveram 
consequências a dois níveis: por um lado, o desinvestimento nas redações, de onde foram afastados os jornalistas mais experientes, por outro, a aposta numa informação capaz de seduzir o público, mas que passou necessariamente pela tabloidização (Pinto, 2008: 10-11). Neste sentido, chamamos à colação o conceito de hiperconcorrência, proposto pelos investigadores canadianos Jean Charron e Jean Bonville, segundo o qual o centro gravitacional dos media, no tempo presente, é a disputa pela conquista de públicos, através de procedimentos de sedução, muito mais próximos de lógicas de entretenimento hollywoodescas do que de estratégias estruturantes da informação. A necessidade febril de conquistar leitores e espectadores conduziu o jornalismo a um caminho, certamente mais fácil, de optar por um conjunto de estratégias, também nada inovadoras, mas que se vislumbram como receitas propícias a captar a empatia dos públicos: aquilo a que, no fundo, Mário Mesquita chamou já há alguns anos de jornalismo hiperbólico (Mesquita, 2003).

Quando digo que nada disto é inteiramente novo, refiro-me a um aspeto que considero historicamente relevante: a partir do momento em que o jornalismo, neste caso, a imprensa se industrializa adquirindo contornos e matizes semelhantes aos que tem hoje, ela vive esse dilema. Sensacionalismo, excessiva exploração da proximidade, espectacularização: marcas da yellow press, que, no final do século xix, serão responsáveis por uma cisão no campo jornalístico, que, inclusivamente, se refletirá no questionamento da sua legitimidade pública.

Se atentarmos na ampla e acesa discussão que envolveu os intelectuais franceses no fim do século, perceberemos que, a partir do momento em que se massifica, o jornalismo vive este dilema. Entre 1897 e 1898, a Revue Bleue desenvolveu um largo debate sobre o papel da Imprensa, em que se destacaram duas conceções antagónicas de jornalismo: uma de matriz pedagógica que entendia o jornalismo como uma prática com deveres públicos e edificantes, capaz de traduzir ideias e defender princípios, por um lado; por outro, uma conceção mais moderna e consentânea com as inovações importadas do jornalismo americano, que colocava a ênfase na vertente lúdica dos conteúdos do jornal. No fundo, este debate traduzia a tensão sentida no universo jornalístico francês do final do século, como o expressa eloquentemente Ferenczi: 
"os primeiros têm a nostalgia de um jornalismo que pusesse em primeiro plano a literatura, as ideias, a política, que não estivesse sujeito às procupações do dinheiro e que não procurasse multiplicar as reportagens no terreno. Os segundos desejam uma imprensa que tivesse como missão descrever a realidade (...) oferecendo ao público informações exatas, precisas, seguras." (Ferenczi, 1993: 235) $)^{113}$.

Quer isto dizer, portanto, que face às vincadas mudanças no universo da imprensa, decorrentes da propagação das práticas americanas, intelectuais e jornalistas franceses, formados numa arreigada tradição histórica segundo a qual literatura, política e jornalismo se harmonizavam, recusam ceder aos constrangimentos da massificação da imprensa ${ }^{114}$. Ainda no decurso do debate acima referido, aliás lançado pelo filósofo Alfred Fouillée, o senador francês Bérenger, homem de letras e jornalista, abriu a discussão, isolando os dois grandes vícios desta nova imprensa: o excessivo gosto pelo espetacular e sensacional e a corrupção pelo dinheiro (Delporte, 1995: 30-31), afinal, dois dos aspetos que mais críticas suscitaram dos intelectuais oitocentistas e que atualmente têm sido retomados como mote por todos quantos veem de fora o jornalismo ${ }^{115}$.

\section{Em busca da narrativa perdida}

Pretendemos, nesta nossa breve abordagem, perceber o conceito de crise de leitura que afeta os jornais impressos nacionais, defendendo a tese - que, confessamos, não é totalmente original - de que o jornalismo pode encontrar

\footnotetext{
113 Tradução nossa.

114 Num artigo em que analisa a obra Le Sieur de Va-Partout, da autoria de Pierre Giffard, Myriam Boucharenc sintetiza bem esta oposição entre os defensores do velho jornalismo e aqueles que aderiram ao novo jornalismo anglo-americano: "Na aurora da sua modernidade, o jornalismo ainda é largamente um depositário da herança do Segundo Império. (...) a imprensa francesa permanece dominada pelos "velhos marechais da crónica" e só timidamente segue o exemplo dos Stanleys ultramarinos. O confronto é então vivo, e bem conhecido, entre os seguidores do «velho sistema", que lamentam a intrusão da reportagem no muito literário jornal francês (...) e aqueles que se passaram a chamar "Os novos jornalistas", entre os quais Fernand Xau, fundador do Journal, Hugues Leroux, escritor e repórter prolixo, ou ainda Jules Huret, todos advogando um jornalismo de investigação que agradasse ao público." (Boucharenc, 2004: 512). Tradução nossa.

115 Os textos de Carlos Camponez e de João Figueira, publicados neste volume, abordam de forma circunstanciada o panorama da crise do Jornalismo.
} 
um último reduto, caso decida fazer um exercício retrospetivo, recuperando algumas das características que tinha nas suas origens. Sem querermos enveredar por caminhos reacionários ou passadistas, e tendo a perfeita noção da distância de tempos e de contextos, julgamos que o importante papel que a imprensa teve ao longo do século xix pode ser parcialmente recuperado, o que passará, naturalmente, não só por uma revisão do papel dos jornais, mas também por uma abertura destes a novos agentes, implicando uma revisão do papel da escrita e da narrativa na construção dos acontecimentos.

Num artigo recente, precisamente dedicado aos media europeus face à crise, Nobre Correia afirma que se assiste hoje a uma redefinição da função social da imprensa e a uma profunda mutação das práticas jornalísticas. Segundo este estudioso, os jornais em papel recuperarão as funções que inicialmente tiveram ao longo do século xix e nos princípios do século xx, publicando grandes reportagens, análises aprofundadas, opinião e comentários, relegando para o jornalismo digital a função meramente informativa (Correia, 2010: 313).

Este prognóstico, embora não seja propriamente novo nem original, tem sido objeto de discussão por parte de alguns autores e de alguns, poucos, jornalistas. A nós, para a reflexão que aqui partilhamos, interessa-nos retomar este tópico, sobretudo porque julgamos que este novo paradigma do jornalismo escrito, um paradigma "a haver", passa necessariamente por uma profunda reflexão acerca das potencialidades da narrativa como modo fundacional do discurso mediático.

Na década de 60 do século passado, um grupo de grandes repórteres norte-americanos, face àquilo que consideravam ser um divórcio dos leitores em relação ao jornalismo, decidiu revolucionar os modos de reportar, acabando por ter ficado na história como o movimento do New Journalism, tão polémico e problemático. Exemplos célebres como Tom Wolfe, Gay Talese, Truman Capote, Norman Mailer, Tomas B. Morgan, Brock Brower, todos grandes jornalistas de publicações de referência americanas, dotados de excecionais capacidades de escrita, começaram a fugir à escrita padronizada do jornalismo, criando verdadeiras peças narrativas que rapidamente ombrearam os grandes romances da Literatura, quer pela sua qualidade estilística, quer pela densidade das suas tramas: reportagens e artigos que fugiam aos padrões da imparcialidade, isenção, objetividade e cinzentismo da linguagem jornalística, aproximando-se muito da escrita literária. 
Antes, porém, de olharmos para as consequências deste tipo de abordagem jornalística, convém que a entendamos, até porque a questão renasceu na primeira década do século xxi. Para isso, parece-nos crucial reler o "texto-programa" deste movimento, escrito na década de 70 por Tom Wolfe ${ }^{116}$. Na segunda parte, a central do ensaio, o autor explica o que era este movimento, bem como algumas das suas características, começando por exprimir que aquilo que mais o fascinou foi, não apenas o facto de perceber que se conseguia escrever artigos fiéis à realidade empregando técnicas literárias, típicas do conto ou do romance, mas sobretudo descobrir que se podia recorrer a qualquer artifício literário para provocar o leitor de um modo simultaneamente "intelectual e emotivo". No fundo, tratava-se de uma alteração da atitude do jornalista face ao acontecimento: se, no jornalismo tradicional, o repórter se esforçava por ser uma "testemunha objetiva", distanciando-se o mais possível, no ato da escrita; no novo jornalismo, não só a intromissão do "eu" é permitida, mas a presença do jornalista no acontecimento torna-se o fio condutor da narração, garante da economia narrativa.

Wolfe exemplifica, com artigos seus, os procedimentos que começou a adotar e que se assumem como as principais diretrizes desta nova forma de fazer jornalismo: 1) a vOz do narrador deve ceder espaço à vOz das personagens, devendo ser uma voz comprometida e não a voz cinzenta e neutral que era comum nos artigos jornalísticos ${ }^{117}$; 2) a apologia das mudanças de perspetiva e de ponto de vista, utilizando habilmente os códigos narrativos apropriados para esse fim ${ }^{118}$; 3) a forma de recolha do material também era diferente e muito mais ambiciosa, postulando uma maior proximidade entre fontes e repórteres. Jornalistas como Capote $^{119}$ ou Talese fomentaram o hábito de passar dias inteiros com as pessoas

116 No seu ensaio O Novo Jornalismo, o autor explica o contexto sociocultural da emergência desta nova escrita, a sua ligação a técnicas romanescas mais antigas, nomeadamente às do romance realista, o estado de letargia dos romancistas norte-americanos daquela época e a saturação do leitor perante um certo tipo de jornalismo. Trata-se de um texto incontornável para entender a fundo a revolução desencadeada por estes jornalistas-escritores (Wolfe, 1990).

117 "Gostei da ideia de conseguir um artigo que fizesse com que o leitor, através do narrador, falasse com as suas personagens, se entusiasmasse com elas, se identificasse." (Wolfe, 1990: 29).

118 "Em vez de me apresentar como o locutor radiofónico que descreve a grande parada, deslizava o mais rapidamente para o olhar das personagens do artigo. Com frequência, mudava o ponto de vista a meio de um parágrafo ou até de uma frase." (Wolfe, 1990: 31).

11 De facto, no seu trabalho A sangue frio, Capote entrevistou centenas de pessoas próximas da família Clutter e dos assassinos, acumulando documentos suficientes para encher um pequeno quarto. Passou seis anos da sua vida em pesquisa para a história, criando inúmeros amigos na pequena vila de Holcomb, no Texas. 
sobre as quais escreviam, a fim de captar detalhes como expressões faciais, diálogos, gestos, ambientes. Quer isto dizer que a revolução provocada por estes escritores-jornalistas passou não apenas por drásticas alterações na metodologia de pesquisa, requerendo uma imersão do jornalista nas situações, mas também um amplo aproveitamento de signos narrativos, até aí preteridos pelo registo neutral da imprensa.

$\mathrm{Na}$ terceira parte do ensaio, Wolfe enumera outros quatro procedimentos narrativos que fazem parte desta nova técnica ou arte de reportar o real: a construção cena a cena, evitando a narração histórica; o registo do diálogo na sua totalidade, desnudando a personagem ao leitor na sua totalidade, com maior eficácia e rapidez; o recurso à focalização interna; e, finalmente, a exploração do detalhe, conseguido pela valorização da descrição de gestos, sons, cheiros, comportamentos, poses e estilos.

No fundo, aquilo que estes novos jornalistas fazem, segundo Tom Wolfe, é seguir as técnicas do Realismo, particularmente do Realismo oitocentista à Balzac ou à Dickens, começando instintivamente a descobrir os procedimentos que conferiam ao romance realista a sua força única: a capacidade para apaixonar, absorver, através de uma comunicação emotiva fundada na realidade concreta. Ou seja, a imersão exigida ao repórter era a condição sine qua non para a promoção da imersão do leitor, através da criação de um relato que o envolvesse, provocando, no fundo, aquilo que em termos literários podemos chamar de estranhamento ${ }^{120}$.

Esta brevíssima descrição dos procedimentos dos novos jornalistas norte-americanos permite perceber o alcance da polémica que envolveu a receção dos seus trabalhos, quer por parte de jornalistas e jornais mais conservadores, quer por parte de críticos literários ou homens de letras. O epíteto de "parajornalismo" ou "jornalismo bastardo" foi veiculado por conceituados jornais

120 Neologismo proposto pelo formalista russo Viktor Chklovski em "A arte como processo", ensaio publicado na segunda edição da Poetika em 1917. "Para Chklovski, o contrário é que é válido: "A finalidade da arte é dar uma sensação do objeto como visão e não como reconhecimento; o processo da arte é o processo de singularização [ostraniene] dos objetos e o processo que consiste em obscurecer a forma, em aumentar a dificuldade e a duração da perceção. O ato de perceção em arte é um fim em si e deve ser prolongado; a arte é um meio de sentir o devir do objeto, aquilo que já se 'tornou' não interessa à arte." O estranhamento seria então esse efeito especial criado pela obra de arte literária para nos distanciar (ou estranhar) em relação ao modo comum como apreendemos o mundo, o que nos permitiria entrar numa dimensão nova, só visível pelo olhar estético ou artístico." (Ceia, 2011). 
como The New York Review of Books e Columbia Journalism Review. De facto, a variedade e veemência das críticas provocadas pelas reportagens, peças e perfis destes jornalistas, desde meados da década de 60, é por si um sintoma do seu impacto. Vários críticos concluíram que este Novo Jornalismo era perigoso por diversos motivos: arriscava tornar as notícias em mero entretenimento; os diálogos e as cenas poderiam distorcer os factos; as fronteiras entre ficção e factualidade poderiam matizar-se.

No fundo, aquilo que era criticado a este movimento prendia-se com uma questão crucial e muito sensível no jornalismo moderno: a da objetividade. A vertiginosa aproximação destas reportagens à literatura fazia perigar os conceitos de realidade e de factualidade, prementes no jornalismo. Se lermos uma declaração de Truman Capote, em entrevista à New York Book Review em 1966, ano do lançamento do seu sucesso editorial In Cold Blood, conseguiremos captar melhor o que está aqui em causa:

"Parecia-me a mim que jornalismo, reportagem poderiam esforçar-se por atingir uma nova forma de arte séria: a nonfiction novel como eu a imaginei. Muitos admiráveis repórteres (...) mostraram as possibilidades da narrativa de reportagem (...) No seu conjunto, ainda, o jornalismo é o mais subestimado, o menos explorado dos media literários." (Capote, entrevista a New York Book Review, 1966).

Estamos perante um paradigma radicalmente diferente de fazer jornalismo, totalmente distanciado da construção narrativa formatada pelo modelo industrial. O próprio conceito de nonfiction novel é na essência problemático: onde termina a factualidade e começa a ficção? Poderemos considerar o jornalismo um medium literário? Como defender a utilização de técnicas, no fundo importadas da narrativa ficcional oitocentista, para construir histórias credíveis e que mantenham o pacto de verdade com os leitores? Na verdade, as técnicas ficcionais do Novo Jornalismo derivam da combinação do jornalismo periódico e da arte de contar histórias que fez nascer o romance no século xviII.

Numa recente entrevista dada à Pública por Mark Kramer, conceituado professor e jornalista, o tema é recuperado. Segundo este autor, uma das formas 
de contornar a atual crise do jornalismo, nomeadamente do jornalismo escrito, será a recuperação destes princípios defendidos pelos repórteres norte-americanos da década de 60. Curiosamente, uma das motivações que explicam contextualmente o surgimento do Novo Jornalismo nos Estados Unidos são de índole comercial e económica. Na verdade, como explica John Hollowell, nos finais dos anos 50, os custos de produção e a baixa das receitas publicitárias devida à era dos media eletrónicos, como a televisão, obrigaram muitas publicações a encerrar a sua atividade. Assim, uma das saídas para esta crise foi lançar no mercado novas experiências, das quais a "não ficção" foi a mais importante, tornando o jornal e a reportagem mais apelativos para os leitores.

Regressando a Mark Kramer, o modelo defendido por este autor é o de um jornalismo narrativo:

"A minha análise da utilidade da narrativa sugere que, mostrando a complexidade das histórias que são notícia e a real situação humana dos seus intervenientes, situações que os leitores podem compreender facilmente, os jornais podem revitalizar-se e tornar-se mais interessantes" (Kramer, 2010).

Alertado para a perigosa e indesejável contaminação do jornalismo pela literatura, Kramer privilegia o termo jornalismo narrativo em detrimento do de jornalismo literário. No fundo, aquilo que é defendido é a reutilização do potencial narrativo dos textos, a exploração de diversas ferramentas narrativas, a fim de restituir aos jornais a sua função primordial: contar histórias, com densidade, que impliquem o envolvimento do leitor, que problematizem o real, traduzindo-o em toda a sua complexidade.

Se pensarmos que toda a prática jornalística passa precisamente por esta capacidade de narrativizar o real, facilmente perceberemos que todo o jornalismo é narrativo, pois todo ele pressupõe a seleção de histórias e a organização discursiva de factos. Ao fazê-lo, qualquer jornalista se desdobra numa voz, submetendo-se a convenções editoriais que lhe ditam as regras de construção e composição de uma história. Aquilo que jornalistas como Mailer, Capote ou Wolfe fizeram foi lutar contra essa tendência de uniformização, defendendo e impondo as suas visões pessoais, as suas sensibilidades e as suas cosmovisões. 


\section{Narrativa e objetividade}

É chegado o momento de uma sistematização prévia. Acabámos de citar duas opiniões sobre esta problemática. Ambas incidem sobre questões que consideramos cruciais nesta abordagem: em primeiro lugar, o facto de o jornalismo narrativo nos conduzir impreterivelmente a uma discussão em torno do conceito de narrativa ficcional; em segundo lugar, a revisão obrigatória do conceito de objetividade, neste contexto; em terceiro lugar, a necessidade imperiosa de se entender a narrativa como forma de acesso natural e intrínseca à condição humana.

Quando Juan Luís Cebrián, numa das suas cartas ao jovem Honório, começa o texto com "não deixes que a realidade te estrague uma boa reportagem" (Cebrián, 1998: 39), enceta, de modo provocatório, um interessante diálogo epistolar sobre a relação entre narrativa jornalística e narrativa literária. Essa relação é transversalmente atravessada por uma problemática, cuja complexidade não é compatível com o espaço de que aqui dispomos: trata-se da relação entre narrativas factuais e narrativas ficcionais. Embora não aprofundemos a questão, parece-nos incontornável explicitar alguns pressupostos de onde partimos.

A questão central pode sintetizar-se da seguinte forma: o que permite distinguir os Cem Anos de Solidão, enquanto exemplar ficcional, de Notícia de um Sequestro? Haverá algum sinal que indique ao leitor quando entramos no mundo possível da ficção? A verdade é que, do ponto de vista formal, os procedimentos textuais inerentes à ficção são os mesmos da narrativa factual. O que nos leva a ler como ficção a descrição do Chiado no final do romance queirosiano $O$ Crime do Padre Amaro? E porque lemos como verídica a História do Portugal Contemporâneo de Oliveira Martins?

Parece-nos, portanto, e seguindo a linha de raciocínio de Umberto Eco, que, do ponto de vista formal, não existe nenhum sinal ostensivo que assinale a narrativa de ficção, distinguindo-a da narrativa factual. Num texto já antigo, parece-nos que o semiótico italiano recoloca muito bem esta questão, defendendo o valor comunicacional das narrativas, cujo autor, título, medium, co-texto e enquadramento ensinariam o leitor a decodificá-las. Quer isto dizer que será no paratexto, enquanto lugar envolvente das narrativas, que se constroem os pactos de leitura que orientarão o horizonte de expectativas do leitor na sua 
decodificação (Eco, 1997). Neste sentido, deveremos perspetivar a ficcionalidade, como modalidade literária, como um conjunto de regras de natureza comunicacional e não estilística, como bem o demonstrou Maria Augusta Babo:

"Do ponto de vista da estrutura narrativa não nos é possível encontrar uma diversidade estruturante entre as chamadas narrativas ficcionais e as ditas narrativas factuais. Quer dizer que os procedimentos textuais inerentes à ficção, na literatura, são os mesmos, do ponto de vista formal, da narrativa histórica ou jornalística. O que se passa é que a condição da própria "mise-en-intrigue"ou narratividade é a da produção, configuração do sentido, independentemente da referência. E essa configuração passa, no entender por exemplo de um Ricoeur, pela organização interna da temporalidade, organização essa que é talvez, para este autor, mais rica de potencialidades na ficção do que na narrativa factual; a diferença não constituindo sequer uma mudança de género mas um grau maior de capacidade a refigurar o tempo e a referencialidade." (Babo, 1996: 3).

Segundo Searl, a ficcionalidade não reside numa qualquer especificidade estilística ou numa qualquer função metafórica da linguagem, mas sim numa intenção de comunicação que é da inteira responsabilidade do autor. Assim sendo, a ficcionalidade é um valor ilocutório do enunciado que se prende com o fingimento intencional do autor, por um lado, e, por outro, está suportada por um conjunto de convenções comunicacionais que a distinguem da mentira e, finalmente, depende do pacto estabelecido com o leitor. No fundo, a questão reside naquilo a que Umberto Eco chama de "protocolos ficcionais", que mais não são do que pactos de leitura previamente estabelecidos entre autor e leitor, geralmente inscritos na zona paratextual (Eco, 1997). Para o que nos interessa discutir aqui, é importante perceber que o jornal é portador implícito de narrativas naturais / factuais, pois o leitor espera encontrar nele histórias reais e não efabulações possíveis. O pacto que o jornalismo estabelece com os leitores é o pacto de verdade e de honestidade: o público lê estas narrativas como índices de real. Mais uma vez é uma questão pragmática que se prende, por um lado, com o protocolo de leitura e, por outro, com uma questão ética e deontológica de honestidade. 
Passemos agora ao segundo ponto atrás enunciado: a questão, igualmente complexa e muito ligada a esta última, da objetividade jornalística. Para Jay Rosen, os critérios de objetividade jornalística têm a ver também com um pacto comunicacional - implícito - entre jornalistas e empresários, assinado no início da industrialização da imprensa. A comercialização de que nos fala Rosen traduz-se, no plano narrativo, numa linguagem cada vez mais sintética, em textos cada vez mais curtos, na uniformização dos temas abordados, etc. Enfim, num jornalismo muito mais pobre em termos de conteúdo, construído por narrativas formatadas, pretensamente objetivas, mas não raras vezes mais subjetivas do que se fossem objeto de trabalho mais apurado. Partindo da análise de um conjunto de narrativas mediáticas portuguesas sobre acontecimentos relativamente recentes, Mário Mesquita ecoa esta opinião, ao aceitar a posição de Deni Elliot, segundo a qual a crise do jornalismo advém de um choque de modelos, entre os "rituais da objetividade" e a vertiginosa velocidade da circulação da informação (Mesquita, 2003).

As narrativas jornalísticas são também construções e representações da realidade que relevam de escolhas ideacionais e interpessoais, para utilizarmos os termos da gramática de Halliday. As notícias não são listas de eventos, nem são factos, muito menos a realidade. As notícias são representações em linguagem verbal e/ou não verbal: representações discursivas e sociais, construções textuais que implicam a intervenção de um conjunto lato de signos e de códigos, que modelam e constroem a nossa perceção da realidade (Tuchman, 2002).

Assim, uma análise semiótica dos jornais deverá considerar que tipo de mensagens são comunicadas pelos códigos do discurso das notícias, os contextos em que essas notícias são produzidas pelos jornalistas e descodificadas pelos leitores, bem como o significado ideológico do discurso noticioso. Ora, um jornal incorpora códigos muito específicos bem como outros usados noutras áreas e produtos sociais, sendo a narrativa um deles (Bignell, 2002: 81-108).

A notícia não é uma categoria fixa que exista naturalmente, resultando antes de um modo de pensar, de selecionar e de compor segundo códigos retóricos, éticos e deontológicos. Assenta numa seleção de factos, assumidos como significativos segundo critérios de seleção específicos, os chamados valores-notícia, partilhados por um corpo profissional e que, afinal, são os responsáveis pela estruturação dos acontecimentos em narrativas de informação. 
Se pensarmos na estrutura narrativa da notícia, tal como foi cristalizada no final do século xix, na era da massificação do jornalismo, perceberemos que nada há de natural na existência de um lead, nem no conjunto de fatores que obrigatoriamente o integram. Esta constatação tem sido estudada pelos historiadores dos media que têm demonstrado que, à época, um conjunto de fatores económicos, políticos e até tecnológicos conduziram o jornalismo norte-americano a ditar uma estrutura tida como eficiente que se coadunava não apenas com a objetividade almejada mas também com a relação comunicacional entre jornais e públicos ${ }^{121}$.

A objetividade é, portanto, um significado mítico do discurso noticioso criado por assunções sobre notícias e sobre a profissão. Se partirmos do pressuposto de que qualquer enunciado em linguagem verbal é produto de uma subjetividade, perceberemos que o texto jornalístico pode ter a objetividade como meta, como baliza, mas nunca a poderá concretizar plenamente. No entanto, citando uma vez mais Mário Mesquita, também é em nome da objetividade e da independência que se insinua o poder do jornalismo. Deste modo, entendemos que o autor recoloca muito bem a questão, entendendo a objetividade como escopo situado a tês níveis distintos: no plano deontológico, como um dever; no plano retórico, como um conjunto de regras estilísticas; no plano de investigação jornalística como um leque de normas processuais (Mesquita, 2003: 207-217).

À semelhança do que constatámos relativamente à ficcionalidade, também a objetividade jornalística deve ser integrada no pacto comunicacional com o leitor, que espera das narrativas textos factuais, honestos, imparciais e objetivos.

A etimologia das palavras narrativa e narração ${ }^{122}$ evidencia a íntima conexão existente entre narrativa e conhecimento. Não é por acaso que desde a nossa infância, as histórias são a principal fonte de conhecimento sobre o mundo e um importante meio de dar sentido à experiência. A narrativa está, portanto,

121 No artigo de Mário Mesquita «Em louvor da Santa Objetividade», são circunstanciadamente explicados os fatores históricos que concorreram para a criação da objetividade, então intimamente ligada a estruturas textuais. É sobretudo a partir do século xix que o conceito de objetividade adquire pertinência no caso do jornalismo, na fase industrial da imprensa: grande público; massificação; credenciação dos jornais; profissionalização dos jornalistas; emergência das agências noticiosas; estratégia comercial. No início do século xx, o conceito impõe-se nos EUA: evitar o sensacionalismo; distinguir-se das Relações Públicas (Mesquita, 2003).

122 Os termos narrativa, narração e narrar derivam do Latim: narrare, narratum e narro, que por sua vez advêm do adjetivo gnarus, que significava sabedor, aquele que conhece. 
presente em todos os lugares e em todas as sociedades: a nossa tendência para organizar a experiência em forma narrativa é um impulso humano sincrónico com a aquisição da linguagem. Temos, pois, uma predisposição primitiva e inata para a organização narrativa da realidade. Inclusive, alguns autores acreditam que já nascemos com um sentido intuitivo e natural para a narrativa e que contar e perceber as nossas vidas como narrativas é algo de comum a todos os grupos e sociedades. Foi esta a tese de Roland Barthes quando, no célebre número 8 da revista Communications, defendeu a transculturalidade da narrativa: as narrativas são um fenómeno universal e até podem evidenciar estruturas universais, defendendo que o estudo das narrativas deve ser um dos mais importantes inquéritos da atividade humana (Barthes, 1968: 1-3).

Uma narrativa é simultaneamente "um modo particular de combinar as partes num todo", um processo dinâmico de comunicação, uma construção de sentido e uma representação social. Partindo destes pressupostos, aceita-se, então, como válida a definição de Labov que define a narrativa como "um método de recapitulação da experiência passada que consiste em fazer corresponder uma sequência de eventos a uma sequência de proposições verbais." (Labov, 1978). Podemos, então, entender a narrativa como o resultado da discursivização da experiência humana: trata-se, no fundo, de construir um processo de representação dinâmica de factos, acontecimentos, passados num tempo específico.

Por isso, perspetivar o jornalismo sob o prisma narratológico também é importante porque nos ajuda a perceber como o conhecimento, os sentidos, os valores são reproduzidos e circulam na sociedade. Porém, as narrativas mediáticas não refletem apenas o mundo real: elas providenciam esquemas mentais e formas de moldar os nossos modos de percecionar, conhecer e acreditar.

Por tudo o que foi dito até ao momento, aceita-se com Carlos Reis que o processo narrativo possa ser descrito em três vertentes: ele decorre de uma atitude de distanciamento assumida por quem narra em relação ao que narra; resulta de uma tendência para a exteriorização, já que descreve e caracteriza um universo autónomo, exterior ao sujeito que o desencadeia; e instaura uma dinâmica temporal que se alimenta não só do devir cronológico da história contada mas também da temporalidade inerente ao próprio discurso (Reis, 1995).

São precisamente estes vetores que, em nosso entender, justificam que a narratividade se revele como o modo fundacional do discurso jornalístico. Mas 
ao fazê-lo, devemos admitir que contar histórias envolve sempre uma atividade de seleção e omissão do material narrável, sendo que o que se omite é por vezes tão importante quanto o que se seleciona. Torna-se, assim, claro que uma narrativa não é uma amálgama de eventos. Quando contamos uma história, tentamos dar sentido a conexões causais entre eventos e ações, também nos preocupamos em situar os eventos no tempo e no espaço, organizando-os numa determinada ordem. O que é caótico, simultâneo, desordenado passa a ter um significado e uma organização.

Esta é, de facto, a tarefa do jornalismo: olhar a realidade, multimodal, desordenada, multifacetada e transformá-la em acontecimento legível. Esta tarefa, que no fundo é a tarefa de qualquer narrador em qualquer situação, envolve uma triagem, uma hierarquização. Envolve escolhas, sempre filtradas por uma subjetividade. Envolve o domínio de um conjunto de códigos que regulam o funcionamento das narrativas, independentemente da sua forma de expressão.

Como afirma Helen Fulton, num mundo dominado por media impressos e eletrónicos, é crucial que percebamos como funcionam as narrativas por eles estruturadas, como explicam as causas e os efeitos dos eventos e das ações, pois esse é um passo imprescindível para que consigamos entender como os media constroem o nosso conhecimento do mundo social e político. As narrativas dos media, tal como as outras, são contadas a partir de perspetivas específicas, privilegiando certos pontos de vista e certas versões, em detrimento de outras, construindo personagens, dando voz a determinados atores sociais e silenciando outros. Saber o que as histórias mediáticas nos contam e aquilo que escondem ou omitem é crucial para entender o exercício de poder em sociedade e para perceber que sentidos são produzidos (Fulton, 2005).

Assim, os Estudos Narrativos defendem a existência de aspetos comuns a todas as narrativas, sejam elas de índole literária, histórica, cinematográfica, televisiva ou jornalística. Estes fatores apontam para a possibilidade de se estudar a narratividade como processo geral que é comum a todas as narrativas. Não cabendo aqui o desenvolvimento do conceito de narratividade, gostaríamos de adotar a perspetiva de Gerald Prince que prevê que a narratividade não pode circunscrever-se a particularidades intrínsecas ao texto, antes deve ser entendida numa aceção pragmática, em que o leitor assume um papel preponderante. Ou seja, para além da dinâmica de transformação desencadeada pelo texto narrativo, 
e salientada por autores como Greimas ou Ricoeur, a narratividade tem de ser considerada em estreita conexão com a instância da receção. Ela pode ser entendida, segundo os autores do Dicionário de Narratologia, como uma qualidade discursiva que é atualizada pelo processo de leitura, ou seja, é um processo inerente à dinâmica de transformação desencadeada pelo texto narrativo, mas é também uma referência latente que organiza a descodificação da narrativa (Reis e Lopes, 1994: 274-285).

Trata-se, portanto, de entender a narratividade neste duplo enquadramento, conjugando a sua vertente de condição específica do texto narrativo, constituída essencialmente pela dinâmica temporal que preside à sua constituição e, por outro lado, como conjunto de características que condicionam e orientam as expectativas de leitura.

Assim sendo, o facto de defendermos para o jornalismo uma linha narrativa não implica necessariamente que entendamos que o princípio da objetividade, entendido como um pacto comunicacional com os leitores, deva ser posto em questão. Nem tão pouco aceitaremos que se confunda o cariz narrativo do jornalismo com a vertente de entretenimento também presente em muitas narrativas mediáticas, nomeadamente nas televisivas. Acreditamos que, ao construir narrativas sobre o mundo, ao tornar legível e ao dar sentido à realidade, o jornalista deve explorar as potencialidades que a narrativa possui, de forma a abarcar a complexidade do real. Ora, tal investimento não é compaginável com a submissão do jornalismo a lógicas de competitividade capitalistas, promotoras de uma simplificação e de um empobrecimento de conteúdos, por um lado, e por outro responsáveis pela manipulação das narrativas, no sentido de as transformar em elementos tão persuasores quanto a publicidade.

\section{Em síntese: jornalismo narrativo}

Partindo desta abordagem pragmática da narratividade, em que ao leitor cabe o papel ativo de refiguração e reconstrução do mundo do texto narrativo, parece-nos fazer todo o sentido defender que, em termos contextuais, o jornalismo escrito pode, de facto, revitalizar-se se enveredar em parte pela aposta noutros tipos de narrativa. 
Esta hipótese pressupõe naturalmente um conjunto de mudanças estruturais, quer na constituição do próprio jornal, quer na mentalidade de editores e diretores. Não se trata, naturalmente, de transformar o jornal num objeto de culto de estrelas escritoras, nem tão-pouco de o remeter para pequenas elites intelectuais. Pelo contrário. Acreditamos poder ser possível enriquecer as páginas dos jornais com novas narrativas, que coexistam com a tradicional forma de fazer jornalismo: apostar nas grandes reportagens, nos perfis, nos artigos de fundo.

Esta mudança, que paulatinamente já começou em algumas redações norte-americanas e brasileiras, em que existem "equipas narrativas" para cobrir esta área, implicará alterações substanciais não apenas na relação do repórter com as pessoas, com as fontes e com os eventos que descreve, mas também e sobretudo na arquitetura e no estilo das histórias contadas que passarão a enriquecer-se com estratégias tradicionalmente ligadas à ficção, sobretudo ao romance e às histórias breves. No fundo, não se trata de abandonar a objetividade mas de a perspetivar de uma forma muito mais profunda: deve ser-se sério e honesto, revelando opiniões pessoais, admitindo preconceitos e valores. Usando técnicas literárias, o jornalismo narrativo constrói informação, conferindo espessura às suas histórias, nem sempre possíveis de obter num jornal ou numa revista noticiosa, e permitindo ao leitor imergir na história de um modo muito mais denso, profundo e completo. Atente-se nas palavras de Gay Talese na célebre obra Fame and Obscurity:

\footnotetext{
"O melhor novo jornalismo, apesar de lido muitas vezes como ficção, não é ficção. É, ou deveria ser, tão real como qualquer outra reportagem, oferecendo uma verdade tão profunda quanto possível através da compilação de factos verificáveis. (...) Mas exige uma abordagem mais imaginativa no ato de reportar."
}

Desta forma, creio que os jornais recuperariam um espaço há muito perdido, em que a imaginação, a poética, a arte de bem escrever responderiam a uma das necessidades dos leitores: sentir prazer na leitura. Na Poética de Aristóteles, o filósofo argumenta que as histórias dão prazer porque imitam a vida e possuem um ritmo próprio, com certas ações e mudanças. De facto, para explicarmos a nossa apetência por histórias, temos de perceber que elas mostram e contam 
os desejos das personagens mas também os das audiências, convidando à identificação e incentivando ao prazer de saber e de descobrir.

Não se trata aqui, sublinhe-se, de fazer a apologia de um jornalismo fundado no conceito de entretenimento ou de ficção. Trata-se, antes, de fazer o elogio do prazer do texto, para roubar um brilhante conceito barthesiano. No fundo, o ideal seria, agora citando Mário Mesquita, fundir a "orientação apolínea" da prática jornalística, que defende o prosaísmo e a objetividade, com a "tendência dionisíaca”, tendencialmente poética e subjetiva (Mesquita, 2004: 56). Cremos que tal sintonia, embora difícil, não é de todo impossível. A nossa história da imprensa recente conta com nomes que foram a prova viva desse enlace.

\section{BIBLIOGRAFIA}

Babo, M. A. (1996). Ficcionalidade e processos comunicacionais. In: www.bocc.ubi.pt

Barthes, R. (1968). "Analyse Structurale du Récit». In: Communications, 8, pp. 1-27.

Bignell, J., (2002), "Newspapers», Media Semiotics An Introduction. Manchester University Press, pp. 81-108.

Bremond, C. (1973). Logique du Récit. Paris: Seuil.

Ceia, C. (2011). "Estranhamento", E-Dicionário de Termos Literários. coord. de Carlos Ceia, ISBN: 989-20-0088-9, <http://www.edtl.com.pt>, consultado em 1/05/2011.

Charron, J. e Bonville, J., (2004). "Le Journalisme et le marché: de la concurrence à l'hiperconcurrence». In: Brin, C. et alii, Nature et Transformation du Journalisme - Théories et Recherches empiriques. Laval: Les Presses Universitaires de Laval, pp. 292-293.

Correia, N. (2010). "L'Europe des Médias face à la crise». In: Les Cahiers du Journalisme, n. 21 - Automne, pp. 298-318.

Delporte, C., (1995). Histoire du Journalisme et des Journalistes en France (du XvII siècle à nos jours). Paris: P. U.F., Col. "Que sais-je?».

Eco, U., (1997). Seis Passeios nos Bosques da Ficção. Carnaxide: Difel.

Ferenczi, T., (1993). Linvention du journalisme en France. Naissance de la presse moderne à la fin du XIX siècle. Paris: Plon.

Fulton, H. et alii, (2005). Narrative and Media. Cambridge, New York: Cambridge University Press.

Hellmann, J., (1981). Fables of fact: the new journalism as new fiction. Chicago, London. The University of Illinois Press. 
Herman, D. ; Jahn, M. ; Ryan, M.-L. (eds.) (2005). The Routledge Encyclopedia of Narrative Theory. London: Routledge.

Hollowell, J., (1977). New journalism and the nonfiction novel. Chapel Hill: The University of North Carolina Press.

Iser, W., (1979). «La fiction en effet», Poétique, no 39, septembre, pp. 275-298.

Keeble, R. and Wheeler, S. (eds.) (2007). The Journalistic Imagination. Literary Journalists from Defoe to Capote and Carter. London e New York: Routledge.

Kramer, M. (2010). «Entrevista» a Paulo Madeira in: Pública.

Labov, W. (1978). "La transformation du vécu à travers la syntaxe narrative". In: Le parler ordinaire. Paris: Ed. Minuit.

Lotman, I. (1973). La Structure du Texte Artistique. Paris: Gallimard.

Mesquita, M. (2003). "Rumos do Jornalismo na Era da Hipérbole». O Quarto Equívoco. Coimbra: Minerva, pp. 53-58.

Mesquita, M., (2000). «Em louvor da santa objectividade», JJ, Janeiro-Março, pp. 22-27.

Pinto, M., (2008). «Digressão sobre a 'crise do jornalismo' - entre definhamento e re-invenção». Texto da lição de síntese apresentada como requisito das Provas de Agregação no ramo de Ciências da Comunicação, Universidade do Minho. In: http://novosmedia.org (consultado em 20/02/11).

Reis, C. e Lopes, A. C., (1994). Dicionário de Narratologia. 4ed., Coimbra: Almedina.

Reis, C. (1995). O Conhecimento da Literatura. 1ªed., Coimbra: Almedina.

Tuchman, G., (2002). "As notícias como uma realidade construída». In: Media e Jornalismo. Lisboa: CIMJ, pp. 91- 102.

Wolfe, T., (1990). The new journalism. London: Picador / Id., (1992), El nuevo periodismo, $5^{\mathrm{a}} \mathrm{ed}$. Barcelona: Anagrama. 
João Figueira

FLUC - CEIS20

\section{A pegada jornalística na paisagem mediática}

"Os media só vão atrás dos carros oficiais". A frase é do jornalista norte-americano, Danny Schechter, que a empregou para questionar o que considera ser o comportamento dominante dos jornalistas. O valenciano Pascual Serrano recupera o conceito, para o aplicar a situações concretas. Diz ele que em março de 2007, enquanto os jornalistas recolhiam diligentemente as frases que George W. Bush fazia na Guatemala, sobre as vantagens do comércio livre no aumento das oportunidades de emprego e no combate à pobreza, ninguém se referiu à unidade de processamento alimentar situada a uma dúzia de quilómetros, e na qual trabalhavam em condições deploráveis menores de 13 anos (Serrano, 2009: 64).

Por essa altura, relembra o mesmo jornalista e especialista em análise dos media, decorria na cidade colombiana de Cartagena das Índias o congresso de língua espanhola, repleto de académicos e líderes políticos. Uma vez mais, assinala Pascual Serrano, os jornalistas estavam demasiado concentrados nas declarações de cada protagonista, ignorando que a escassas centenas de metros do luxuoso hotel onde decorria o congresso, havia um bairro miserável chamado Nelson Mandela, com meio milhão de pobres e um turismo sexual galopante (Serrano, 2009: 64).

Estes dois exemplos revelam o comportamento dominante dos media noticiosos, os quais se pautam, ainda, por uma inexplicável falta de memória. Os detentores de altos cargos políticos sabem que as suas promessas e declarações em cimeiras ou reuniões importantes são sempre objeto de notícia e destaque, sem que os mesmos órgãos de comunicação social se preocupem, seis meses mais tarde, em confirmar se as promessas e os anúncios feitos foram cumpridos. Quer isto dizer, portanto, que, nestes casos, os media noticiosos não nos informam acerca 
do que realmente sucede, mas sobre o que os autores das palavras dizem que vai suceder, porque a atenção informativa está centrada nas declarações de intenção, sem atender às respetivas condições de realização. Ou seja, a informação assim praticada, limita-se às palavras sem depois verificar a sua concretização.

Os casos citados, que como é sabido confirmam a regra de atuação dos media, recentram o debate sobre a informação jornalística nestes tempos de mudança e também de crise, em torno das seguintes questões:

- qual a finalidade do jornalismo e como acrescentar valor à informação jornalística num contexto de perda do monopólio de distribuição da informação?;

- quais os contextos organizacional e comunicacional em que a profissão é exercida?;

- qual o papel dos cidadãos na qualidade da informação fornecida?.

Como veremos, as questões enunciadas relacionam-se entre si numa espécie de vasos comunicantes, porque nenhuma delas existe isolada do conjunto e este é, em grande medida, o resultado da atuação individual de cada uma delas. Por outro lado, esta é, ainda, uma questão crucial do nosso tempo, porquanto, como Dominique Wolton, Manuel Castells ou Furio Colombo oportunamente observaram, todas as sociedades apresentam modelos de comunicação específicos e dominantes, os quais, por sua vez, determinam e influenciam os respetivos modelos informacionais. "Se construímos modelos comunicacionais nas nossas sociedades é também verdade que os principais paradigmas comunicacionais formatam o que um determinado sistema de media será"123.

Ora, nunca como agora, os dois modelos suscitaram tanta reflexão e debate, fruto do seu relacionamento nem sempre fácil e pacífico e, por isso mesmo, gerador de um clima que nos apresenta desafios e problemas.

"O modelo comunicacional da nossa sociedade contemporânea — segundo Gustavo Cardoso - é moldado pela capacidade dos processos de globalização comunicacional mundiais, juntamente com a ligação em rede entre media de massa e media interpessoais e, em consequência, pelo aparecimento da mediação em rede". ${ }^{124}$

123 "Da comunicação de massa para a comunicação em rede", in Media, Redes e Comunicação, (Coord) Gustavo Cardoso, Francisco R. Cádima, Luís L. Cardoso, Quimera, 2009, Lisboa, p. 16

124 "Da comunicação de massa para a comunicação em rede", in Media, Redes e Comunicação, (Coord) Gustavo Cardoso, Francisco R. Cádima, Luís L. Cardoso, Quimera, 2009, Lisboa, p. 16 
O seu ponto de vista, estribado no pensamento de Castells sobre a comunicação em rede, aponta para a afirmação de um novo paradigma "caracterizado pela fusão da comunicação interpessoal e em massa, ligando audiências, emissores e editores sob uma matriz de media em rede"125. Ou seja, coloca os utilizadores e as literacias de que estes necessitam no centro do processo comunicacional. Para Gustavo Cardoso, "o ideal da pessoa informada neste início de século é alguém que sabe produzir conhecimento a partir de todas as notícias disponíveis em diferentes media, com diferentes profundidades de análise e que as pode, e sabe, cruzar com análises mais extensas sobre diferentes assuntos"126. Sem nunca esquecer que na sociedade em rede na qual ele se situa, é a comunicação em rede que predomina e, nesse sentido, aponta para uma valorização da busca de informação no interior desse universo e da sua troca entre os diversos membros das respetivas redes sociais.

Tal pensamento traz consigo a ideia de uma mudança cultural no que toca ao conceito que se faz sobre o que é ser um cidadão informado, muito especialmente no que toca aos processos de troca e acesso à informação, na linha, aliás, do que o investigador norte-americano especialista em economia dos media, Robert Picard defende, quando centra a sua análise e olhar nos aspetos vincadamente económicos do processo informativo. Dentro desse quadro, a informação nem sempre é o bem público, na perspetiva que Bill Kovach e Tom Rosenstiel apontam, quando dizem que "a finalidade do jornalismo não é definida pela tecnologia nem pelos jornalistas ou pelas técnicas que estes empregam, mas pela função que as notícias desempenham na vida das pessoas" (Kovach ; Rosenstiel, 2004: 15). Porque, entendem os mesmos autores, "a principal finalidade do jornalismo é fornecer aos cidadãos a informação de que precisam para serem livres e se autogovernarem" (Kovach ; Rosenstiel, 2004: 16). Nesta perspetiva, o jornalismo "é um saber prudencial que consiste na comunicação adequada do saber sobre as realidades humanas atuais que aos cidadãos é útil saberem para agirem livre e solidariamente" (López, 2001: 258).

O problema, digamos assim, é que atualmente os jornalistas e as empresas para as quais trabalham têm hoje um controle menor sobre os fluxos informativos

\footnotetext{
125 Idem, p. 17

126 Idem, p. 20
} 
e a sua distribuição. De acordo com Robert Picard, as mudanças sociais, económicas e tecnológicas reduziram o papel desempenhado pelos jornalistas e empresas de comunicação social nas sociedades modernas atuais, em que existem mecanismos alternativos que permitem ao público obter, criar e distribuir notícias e informação.

Na conferência que deu no Instituto Reuters para o estudo do Jornalismo, na Universidade de Oxford, a 6 de maio de 2009, sob o título, "Why journalists deserve low paid" e cujas linhas de força e reflexão aprofundou no seu mais recente livro, Value creation and the future of news organizations: why and how journalism must change to remain relevant in the twenty-first century, onde discorre sobre as mudanças que o jornalismo e as empresas de comunicação social têm necessariamente de fazer no contexto de um novo quadro comunicacional determinado pela nova paisagem mediática e de mercado, Robert Picard entende que hoje os produtores de informação noticiosa não têm o poder centralizador e dominador do passado, porquanto agora existe uma ampla rede de fontes capazes de responder, por eles e como eles, às funções e benefícios que, do seu ponto de vista, cabe ao jornalismo desempenhar.

Partindo da ideia de criação de valor inspirada na teoria económica, segundo a qual o valor do produto final terá de ser superior à soma do valor dispendido, parcelarmente, em cada um dos recursos usados na respetiva produção, o mesmo investigador critica a generalizada ausência de valor acrescentado na informação noticiosa, o que a torna, por seu turno e aos seus olhos, igualmente pouco diferenciada. Em síntese, aquilo que Robert Picard afirma é que a generalidade dos jornalistas dispõe das mesmas competências e tem os mesmos ângulos de abordagem, recorre às mesmas fontes, faz perguntas idênticas e escreve textos relativamente semelhantes. Daí, sustentar que este trabalho pouco diferenciado e facilmente substituível explica os salários baixos da média dos jornalistas, em contraste com os pagamentos mais chorudos feitos aos colunistas, cartoonistas e jornalistas especializados.

Em Robert Picard existem preferencialmente consumidores em vez de cidadãos e a informação jornalística é vista e analisada segundo a satisfação de três benefícios: funcional, emocional e identitário. Ora, quando tais benefícios podem e passam a ser satisfeitos através e junto de outros meios e fontes, isso significa que o produtor inicial deixa, como sucedeu durante o último século, de 
ter o monopólio na distribuição da informação e de ter esse mesmo exclusivo no acesso a fontes autorizadas e ao espaço público mediatizado.

"A emergência de canais noticiosos durante as 24 horas, os talk-shows e a internet oferecem às pessoas a possibilidade, nunca antes experimentada, de seguir acontecimentos em tempo real, receber informação diretamente de entidades conhecedoras e autorizadas e, ainda, de interagir com as fontes de informação através de uma multiplicidade de formas e plataformas nunca antes tornadas possível"127, realça ainda Robert Picard, para quem os novos meios de comunicação reduzem o valor do trabalho anteriormente desempenhado pelos jornalistas que eram os únicos que tinham a possibilidade de aceder e relatar os acontecimentos, assim como detinham a exclusividade no acesso às fontes e ao conhecimento. "O primeiro valor económico do jornalismo - observa o mesmo autor - reside não no seu conhecimento próprio, mas na capacidade de distribuição do conhecimento dos outros"128, vantagem essa que se esbate ou desaparece, a partir do momento em que existem outras opções.

Donde, se agora existem organizações e mecanismos alternativos capazes de executar as mesmas tarefas e responder às mesmas solicitações e expectativas do público ou, dito de outra maneira, se este pode aceder e comunicar sem necessitar da intermediação de qualquer instância jornalística, isso traduz, à luz do pensamento de Robert Picard, uma menor dependência dos consumidores face aos media noticiosos e uma fragilidade crescente destes e dos seus profissionais no quadro da respectiva atuação.

Percebe-se porquê. Afinal de contas, como chega, hoje, a informação a uma parte considerável dos cidadãos? Pois bem, deixando de lado qualquer análise sobre a qualidade em que se processam os novos circuitos informativos, aceitemos como certa a ideia - facilmente constatável, de resto - de que a uma parte cada vez maior dos cidadãos, a informação chega-lhe, sobretudo, através da net e das suas múltiplas redes sociais, em mensagens curtas e reduzidas. Significa isso que, gradualmente, estamos a habituar-nos, como cidadãos, a tomar como representações da realidade as micronarrativas dessa mesma realidade, o que torna a informação e a apropriação da respetiva realidade ainda mais simplista.

127 "Why journalists deserve low paid", Conferência apresentada por Robert Picard, no Reuters Institute for the Study of Journalism, University of Oxford, 6/05/2009, p. 4

128 Idem, p. 3 
Motivo este, dir-se-á, que reforça a ideia de necessidade de uma informação mais completa feita por jornalistas, segundo os critérios e os princípios da profissão.

É sabido que o jornalismo procura transmitir de forma simples e acessível o que é complexo. O risco atual reside em transmitir apressadamente e de forma simplista apenas o que é simples. E o risco é real e propaga-se à velocidade da luz. De uma forma tendencialmente crescente, como sustenta Adriano Duarte Rodrigues, "são as redes mediáticas que dimensionam a comunicação em termos universais. Quebram, no espaço e no tempo, as fronteiras convencionais; mobilizam e mantêm disponíveis conteúdos múltiplos, colocados ao acesso de contextos virtuais muito diversificados. São estas redes mediáticas que, em virtude das suas potencialidades, flexibilidade e performatividade — acrescenta o mesmo investigador — dão a exata dimensão do espaço público contemporâneo: já não um espaço essencialmente topológico e físico, mas, cada vez mais, um espaço simbólico e reticular" (Rodrigues, 2001: 123), em circulação permanente nas autoestradas da informação, as quais "encarnam a ilusão de um tempo único da informação", como se a "ideologia técnica” pudesse, por si só, cumprir essa utopia do tempo único mundial, por esbatimento dos "tempos históricos locais" (Wolton, 1999:291).

No entanto, como nos alerta Dominique Wolton, se é verdade que a sociedade imperial da tecnologia pode permitir-nos seguir e ver tudo, isso não significa, como ele próprio também assinala, que se possa compreender tudo ${ }^{129}$. Crítico daquilo a que designa por "ideologia técnica", Wolton defende que toda a comunicação é uma relação de forças, sublinhando, a este respeito, que o horizonte de qualquer comunicação está na relação com o outro.

Daí colocar o fator humano no centro e razão de ser do processo comunicativo $^{130}$, o qual, em seu entender, comporta três tipos de comunicação intersubjetiva ou humana, mediática e a internet - aceitando que todos eles desempenham um papel próprio e que, por isso mesmo, não faz sentido escolher

129 A reflexão em torno dos problemas e dos desafios que se colocam à comunicação, colocada perante os avanços tecnológicos e as desigualdades que eles acentuam, constitui um elemento essencial do pensamento do autor. Resultado de 20 anos de pesquisa e investigação, Dominique Wolton critica neste seu livro - Pensar a comunicação (1999) - obra central no seu vasto trabalho, o domínio da "ideologia técnica" e aponta para a necessidade de uma redescoberta e reforço das identidades.

130 Em seu entender, "qualquer teoria da comunicação que não enuncie formalmente a visão da sociedade que lhe está associada é caduca", na medida em que "não existe teoria da comunicação sem uma teoria da sociedade", (Wolton, 1999: 41) 
ou prescindir de um deles, mas antes conjugar ou concertar as três formas de comunicação numa espécie de conciliação estratégica, em que o significado e a narrativa da comunicação apresentam marcas culturais e ideológicas que escapam à gramática exclusivamente tecnicista do dispositivo comunicacional.

Em Pensar a comunicação, Wolton sustenta, aliás, que a verdade não está no ato de mostrar tudo e dizer tudo, razão pela qual propõe o reforço do papel do jornalista como intermediário generalista entre o espetáculo do mundo e o público, mesmo sabendo que a informação não se reduz à narrativa do acontecimento. Isto, porque a lógica comunicacional, de que a vertente noticiosa é parte integrante, mas não exclusiva, é hoje dominada pela cultura da espetacularidade, onde a sobremediatização dos acontecimentos e a dificuldade em os apresentar em perspetiva, constituem sinais marcantes e preocupantes do exercício atual da informação noticiosa.

"De repente, desliza-se facilmente da ideia de liberdade devida à ausência de intermediários, para a ideologia da imediatez. Tudo é público e imediato” (Wolton, 1999: 183). E assim sendo, a "aventura já não é o acesso ao acontecimento mas, sim, a sua compreensão. Demasiada informação mata os factos e a sua compreensão. Este é o resultado paradoxal da vitória do paradigma da informação: o acontecimento satura a informação. Ou melhor, a informação, em vez de ser a escolha entre diversos acontecimentos, torna-se, simplesmente, a sua soma" (Wolton, 1999: 225). Estaremos, à luz deste raciocínio, a assistir à morte da notícia e ao esgar dos critérios de noticiabilidade?

$\mathrm{Na} 4^{\mathrm{a}}$ Conferência Internacional de Jornalismo realizada em novembro de 2010, em Estrasburgo, Philippe Lefait, do canal televisivo France 2, na linha das palavras de Wolton, lançou o seguinte grito de alarme: "o excesso de informação mata as notícias"131. Queria ele dizer com isso que o jornalismo tem de recuperar os seus fundamentos, realçando que se "antigamente os cidadãos eram questionados pelos jornalistas, agora lidamos com um público consumidor e jornalistas vendedores"132.

Jérome Bouvier, presidente deste encontro internacional que junta atores da informação e públicos para debaterem a qualidade da informação, considera que

\footnotetext{
131 "O tempo dos slow media", in Courrier International, n 179, Janeiro 2011, p. 73

132 Idem
} 
a possibilidade de a profissão de jornalista, como hoje a conhecemos, poder vir a desaparecer dentro de uma década está longe de ser um risco sem sentido.

Como ele, o movimento slow media, criado em janeiro de 2010 na Alemanha, sustenta que o jornalismo "é uma profissão que precisa de tempo", quando o seu exercício atual se resume em correr mais depressa que o respectivo concorrente. Tal "vertigem de imediatismo", para usar a expressão de Bouvier, está a arruinar a profissão, uma vez que se incentiva a velocidade e a profusão de notícias, em detrimento da sua seleção cuidada e de um tratamento qualificado da informação.

O coro das vozes desencantadas sucede-se. Patrick de Saint-Exupéry, chefe de redação e cofundador da revista francesa $X X I^{133}$, publicação trimestral vocacionada para a grande reportagem e que sobrevive graças aos 52 mil exemplares que vende, dado que não aceita publicidade nas suas páginas, sublinha que a sua equipa, quando trabalha, "tem sempre presente que está a escrever para alguém e que esse alguém é um leitor, não é um destino"134 .

Até que ponto é que esta revista, rentável e com as contas equilibradas, não responde à ideia de diferenciação e de valor acrescentado de que Picard nos falava há pouco?

É interessante observar como perante o exercício de uma profissão e de uma atividade económica, em clara derrapagem e em inquestionável fase de transformação, o pensamento predominantemente editorial se aproxima, no plano das suas opções estratégicas, do olhar economicista.

Robert Picard entende que a sobrevivência do jornalismo está na sua capacidade de inovar e criar novas formas de aproximação, processamento e distribuição de informação, de modo a disponibilizar conteúdos e serviços a que os seus públicos não possam aceder de outra maneira. E se assim for, esses mesmos públicos, que este investigador classifica de consumidores, estarão dispostos a pagar um preço razoável pela informação em causa. Para que isso aconteça, o mesmo autor alerta para a importância decisiva das lideranças no quadro das decisões estratégicas das respetivas organizações, porquanto elas têm, em seu entender, de olhar para os interesses amplos e diferenciados dos seus stakeholders,

133 A 24 de Março de 2011, a mesma equipa lançou a revista semestral 6 Mois, inteiramente dedicada à foto-reportagem. Como a XxI, não aceita publicidade e também não se encontra à venda nos quiosques - apenas se compra em livrarias ou em assinatura pela internet.

134 "O tempo dos slow media", in Courrier International, $\mathrm{n}^{\circ} 179$, Janeiro 2011, p. 73 
numa perspetiva de superação dos meros objetivos perseguidos pelos respetivos sharebolders, a fim de conseguirem encontrar formas de incorporar valor suficiente no jornalismo, para que os consumidores o suportem financeiramente (Picard, 2010). Quer isto dizer, ainda na linha de pensamento do mesmo autor, que o jornalismo tem de ser capaz de inovar e de encontrar fórmulas novas e mais exigentes de prestar a informação, embora admita que o modelo de negócio que possa suportar uma opção desta natureza não é fácil de encontrar e de pôr em prática.

A esta mesma conclusão chegaram, de resto, recentemente, em Madrid, os diretores de Le Monde, El Pais The Guardian, The New York Times e Der Spiegel, durante um debate sobre "O futuro do jornalismo" ${ }^{35}$, realizado no museu Reina Sofia.

O pretexto do debate foi a publicação, por aqueles órgãos de comunicação social, dos telegramas disponibilizados pela Wikileaks, mas a ocasião foi aproveitada para discutir o novo cenário informativo e o papel e a relação do jornalismo com os cidadãos, em especial através do on-line, visto ser esse o meio em que todos os intervenientes apostam fortemente e no qual, acreditam, está o futuro. Divide-os, no entanto, uma questão central: como pagar um jornalismo de qualidade num quadro comunicacional predominantemente gratuito? Georg Mascolo, diretor da revista alemã Der Spiegel, hesita, como os outros, no modelo de negócio a seguir. Contudo, arrancou a maior ovação da tarde quando disse que se recusava a aceitar que uma revista fosse mais barata que um café no Starbucks, porque os custos de uma redação qualificada e o consequente exercício de uma informação exigente têm preços elevados e alguém terá de os suportar.

Esta representa, a meu ver, a questão central da discussão em torno da necessidade de existência de um jornalismo independente, credível e qualificado nos nossos dias, numa altura em que o desenvolvimento do google news, com o seu sistema de acesso e transmissão de notícias, constitui um exemplo notório e notável da massificação informativa a custo zero. Confrontados com uma tendência crescente do acesso gratuito à informação, esta apenas pode ambicionar ter um

135 O encontro foi realizado a 27 de fevereiro de 2010 e foi aproveitado para cada um dos diretores manifestar as suas incertezas quanto às opções de ordem económica a seguir no que toca às edições eletrónicas. Todos concordaram que os respetivos títulos em papel estarão condenados, a prazo, assim como não têm dúvidas que o futuro da informação está no online. 
preço se os seus destinatários estiverem dispostos a pagar por ela, porque a consideram exclusiva, relevante ou útil à resposta das suas necessidades profissionais ou de cidadania.

Colocados perante este dilema que é, ao mesmo tempo, o maior desafio do jornalismo atual e da sua forma de exercício, Robert Picard atira a primeira pedra com a mais profunda das suas convicções: o uso das novas tecnologias, a atenção permanente às redes sociais, a pesquisa de websites especializados, a procura de inspiração para as suas estórias em weblogs e o exercício do chamado jornalismo colaborativo com as audiências, apesar dos aspetos positivos e vantagens que apresenta tal prática, ela, só por si, não acrescenta valor à informação jornalística. Por uma razão simples, em seu entender: a maior parte dos interessados naquelas matérias utilizam, na sua busca e discussão, os mesmos recursos, competências e instrumentos dos jornalistas.

Esta procura ansiosa e permanente por novos conteúdos noticiosos, com o objetivo de os editar o mais depressa possível nas diversas plataformas que cada órgão de comunicação social administra atualmente, tem vindo a conduzir, por seu lado, à afirmação do conceito de marca informativa, em detrimento do velho título que cada media orgulhosamente ostentava no cabeçalho do respectivo jornal. "A imprensa que era artesanal — refere Patrick de Saint-Exupéry — tornou-se numa indústria quase mecânica", ao mesmo tempo que "aos jornalistas foi entregue o papel de técnicos de informação, em detrimento da legitimidade da sua função primordial: dar notícias"136.

É justamente dentro deste quadro de referências que faz sentido atender às palavras de Robert Picard, quando ele aponta para a necessidade de uma nova forma de organização e cooperação entre empresas, mas cuja renovação deve incluir os jornalistas. Nesse sentido, jornalistas e administradores devem promover uma estreita colaboração conjunta e criar um quadro de relacionamento social que possibilite a concretização dos objetivos que são comuns. Paralelamente, sublinha Picard, "os jornalistas têm de adquirir competências ao nível da inovação e do empreendedorismo, de modo a que eles possam também liderar esse processo de mudança, em vez de se limitarem a reagir a ele"137. Caso contrário,

136 "O tempo dos slow media", in Courrier International, n ${ }^{\circ}$ 179, janeiro, 2011

137 "Why journalists deserve low paid", Conferência apresentada por Robert Picard, no Reuters Institute for the Study of Journalism, University of Oxford, 6/05/2009, p. 6 
"se os jornalistas não criarem mais valor no trabalho que realizam e se não se envolverem mais intensamente nos destinos das respetivas empresas — sustenta o mesmo autor — os seus salários serão progressivamente diminuídos, ao mesmo tempo que as suas empresas irão definhar e morrer"138. Para Robert Picard, o jornalismo e as respetivas empresas enfrentam um momento decisivo da sua existência, pelo que uns e outros têm de entender o novo quadro competitivo em que se movimentam e, nessa perspetiva, serem capazes de encontrar as soluções adequadas às atuais circunstâncias (Picard, 2010).

Percebe-se porquê. O jornal "enquanto empresa, local de trabalho e modelo jornalístico baseado apenas na escrita e na fotografia terminou ou, melhor, não terminou ainda, mas encontra-se num processo de mutação, que nos fará olhar para este momento atual como um início de rutura" ${ }^{139}$ Assim sendo, é a própria cultura organizacional e a gestão de recursos humanos que estão em causa. "O desafio é enorme — sustenta Gustavo Cardoso — porque implica que as empresas adotem ciclos de produção adaptados às dietas de media e dos consumidores" e, sobretudo, exige uma nova cultura de gestão, em que a empresa interiorize a prática de atitudes criativas "dirigidas para a conquista de leitores", recusando "soluções únicas, estanques, permanentes". Vendo bem, trata-se, no fundo, de "aprender a inovar nos modelos e não apenas nos conteúdos, recusando também a ideia de um produto final único", enquanto representante de um "pensamento monopolizante". ${ }^{140}$

Da mesma maneira que não há um público mas muitos e diversificados públicos que querem coisas diferentes e a diferentes horas do dia, isso quer dizer que o jornalismo terá de procurar e dar notícias diferentes. Tal como observámos no pensamento de Robert Picard, também Gustavo Cardoso entende que tem de haver uma notória diferenciação e valor acrescentado na informação a veicular, pela simples razão, sublinha, de que o "mediado já chega por via de diferentes fontes, profissionais ou outras, tanto ao jornalista como ao público. O que significa que, para haver diferença, tem de haver mais tempo no terreno, tem de haver

\footnotetext{
138 Idem, p. 6

139 "Da comunicação de massa para a comunicação em rede", in Media, Redes e Comunicação, (Coord) Gustavo Cardoso, Francisco R. Cádima, Luís L. Cardoso, Quimera, 2009, Lisboa, p. 44

140 Idem, pp. 44-45
} 
fontes face-a-face, estar na rua, ir onde a redação não chega, gravar, escrever a partir dos locais dos acontecimentos". ${ }^{141}$

Aquilo que Gustavo Cardoso aqui nos propõe é, no essencial, o regresso do jornalismo ao seu habitat, numa altura em que ele é visto como uma peça de uma sofisticada engrenagem, no interior da qual o jornalista é uma espécie de operador de computador, a quem é exigida uma produção diária de textos que é impossível elaborar segundo o estado da arte da profissão.

A atual era do ciclo noticioso de 24 horas implica que as redações ocupem o seu tempo em busca de novos dados para acrescentar às informações existentes. Sucede, no entanto, que essa procura não traz, em regra, novos dados nem verifica os que foram veiculados. Limita-se a apresentar mais interpretações, porque a cultura jornalística dominante, regra geral, tem vindo a enfraquecer e a desviar a metodologia da verificação que constitui o tronco central do seu trabalho, para o chamado jornalismo de citação.

Tal modelo organizacional e da ação jornalística, como Tom Rosenstiel e Bill Kovach demonstram na sua obra, Os elementos do jornalismo, comporta sérios riscos e, sobretudo, está a retirar os jornalistas do epicentro dos acontecimentos, conduzindo, com essa atitude, ao empobrecimento da própria informação. Os mesmos autores consideram, aliás, que "à medida que os jornalistas passam mais tempo a tentar sintetizar o interminável fluxo de dados que lhes chegam através dos novos portais de informação, correm o risco de se tornarem mais passivos, mais receptores do que colectores de informação" (Kovach e Rosenstiel, 2004:80)

Sem tempo para pensar nem confirmar e muito menos para aprofundar e colocar em perspetiva os textos que escreve, o jornalista limita-se a produzir em série, estando, assim, à mercê das fontes mais bem apetrechadas e que, sabedoras dos constrangimentos organizacionais das empresas jornalísticas, conseguem dominar e influenciar a agenda informativa.

O cenário atual é de grande concorrência e a informação é permanente e instantânea, ao ponto, como diz Debray, referindo-se à ideia de prescrição das notícias, de "reconduzir Sísifo, em cada manhã, ao sopé da montanha" (Debray, 1994: 31).

$141 \quad$ Idem, pp. $45-46$ 
A atualidade, por seu turno, é comandada pelo sensacionalismo e pela dimensão espetacular da informação, ao ponto de ter deslocado a própria política do estrito domínio do confronto e da discussão ideológica para o terreno movediço do fait-divers e do escândalo. "A regra dos duelistas de outrora, a do primeiro sangue" ${ }^{142}$, segundo a expressão de Jean Lacouture, é também a do jornalismo de hoje, cada vez mais atento e preocupado com a construção de uma realidade parcialmente considerada, onde, "tudo o que era diretamente vivido se afastou numa representação", como se as imagens em que nos olhamos e vemos "o espetáculo como inversão concreta da vida" correspondessem à ideia de "pseudomundo à parte", de que nos fala Guy Debord, em "A sociedade do espetáculo" (Debord, 1991: 9).

Perante este cenário, no qual crescem todos os dias os apelos e encorajamentos ao papel do cidadão-jornalista (seja isto o que for), e onde a influência das agências de comunicação e gabinetes de assessoria dispõem hoje de meios incomparavelmente maiores que a generalidade das redações, importa perguntar para que serve o jornalismo? Por outras palavras: qual a sua função nas atuais sociedades, numa altura em que qualquer empresa ou instituição pode, através das redes digitais, comunicar diretamente com os seus potenciais destinatários, sem necessitar da intermediação jornalística?

Na sua génese, o jornalismo comporta os conceitos de independência, verdade, vigilância, interesse público, sem que todas estas características coexistam em simultâneo no mesmo título. Mas elas são o seu ADN, a sua marca d’água. Se assim não for, como podem as sociedades democráticas sobreviver sem uma informação livre e independente?

Esta é uma questão central, por vezes muito ignorada, justamente porque ela não faz parte das preocupações do chamado jornalismo de mercado ${ }^{143}$ que constitui hoje o discurso dominante no espaço mediático. Desligado da ideia de responsabilidade cívica, essa forma de exercer o jornalismo, amiga do conceito de globalidade e defensora da homogeneização dos públicos, professa

142 Lacouture, Jean, "A História imediata", in A Nova História (dirigida por Jacques Le Goff, Roger Chartier, Jacques revel), Almedina, 1990, p. 334

143 Esta ideia é desenvolvida, entre outros, pelo sociólogo Pierre Bourdieu, para quem o campo jornalístico estrutura-se segundo o "polo comercial" e o "polo intelectual". No primeiro, os jornalistas determinam a sua atitude em função do mercado, da audiência; no segundo, atendem à qualidade do produto jornalístico e aos valores da deontologia profissional. 
essencialmente as virtudes do alargamento do mercado, numa perspectiva de aproveitamento das múltiplas plataformas de comunicação disponíveis.

Paralelamente, a informação deixou de ser um exclusivo dos órgãos de comunicação social, para se tornar um conteúdo que as grandes plataformas, sobretudo digitais, colocam gratuitamente à disposição de qualquer pessoa. O mesmo sucede com o fenómeno dos jornais gratuitos que hoje tomou conta das grandes cidades. A ideia subjacente é idêntica: dar de forma rápida, sumária e a custo zero para o destinatário um conjunto de notícias produzidas segundo o sistema de low cost.

Ora, não é possível nem desejável entender este processo como algo que apenas diz respeito aos jornalistas e se esgota na sua função, sem atender ao papel ativo que, neste contexto, nos deve caber a nós, cidadãos.

Se a informação, como já foi dito, visa fornecer instrumentos e dados para os cidadãos melhor decidirem sobre os destinos das suas comunidades e países, mas se esses mesmos cidadãos preferem consumir ou prestar mais atenção a temáticas centradas em escândalos ou na vida pessoal de figuras públicas, isso significa que há um imenso trabalho de fundo para fazer e cujo alvo, entendamo-nos, não se circunscreve apenas às pessoas com menores habilitações académicas.

A grande dificuldade é que o jornalismo de qualidade e de referência, que hoje enfrenta problemas sérios em quase todas as latitudes, não pode esperar tanto tempo. E como também não vive isolado no espaço mediático, os últimos anos mostram-nos uma crescente contaminação dos órgãos de referência por temáticas e espaços editoriais que até há pouco tempo eram do domínio exclusivo da imprensa popular. Este, portanto, e aqui apresentado de modo muito resumido, o enorme dilema do jornalismo atual: mercado desregulado, competição desenfreada pelos públicos e audiências, predomínio do espetáculo e do entretenimento, imediatismo, afirmação dos grandes grupos, aposta na inexperiência e baixos salários, transferência dos públicos para o on-line, sem que tal mudança equilibre, para já, a crise da imprensa e a sua perda dos proventos comerciais.

Tudo nos diz, portanto, que o jornalismo como o entendemos e vimos durante décadas a fio está a acabar. Não direi a sua função, que esta ainda não encontrou um substituto credível e à sua altura. Refiro-me ao modo como ele hoje é entendido na generalidade dos seus contextos organizacionais e também como é praticado e às escolhas das temáticas a que ele dá mais atenção e espaço, 
num contexto tecnológico completamente novo e cujas potencialidades alteraram também a forma de exercício do jornalismo.

Mas se a tecnologia e as técnicas de comunicação mudaram, os princípios do jornalismo mantêm-se inalterados, não obstante as transformações que a profissão está a enfrentar. Claro que a fragilização das redações, acompanhada por uma estratégia de comunicação assente em linguagens e critérios alheios ao jornalismo tornam este mais fraco e dependente.

O jornalismo, com se sabe, tem um valor instrumental, cuja relevância é exterior a si próprio. Isto é, o jornalismo não é importante em si mesmo, da mesma maneira que o seu exercício não é um discurso sobre si próprio; a sua importância comporta uma dimensão instrumental, no sentido em que a sua prática visa o esclarecimento do público, apoiar a interação social, assumir-se como um elemento facilitador e de dinamização do jogo democrático.

Resta saber, portanto, à luz desta observação, qual o grau de responsabilidade que o cidadão deve ter na defesa e preservação de um jornalismo de qualidade, dado que enquanto recetor e nas palavras de Mauro Wolf "é parte ativa do processo de comunicação"144. Hugo Aznar pergunta se "pode o público continuar a ser considerado como alheio ao processo de comunicação e a sua participação nos media como uma intromissão?", para defender que tal "participação não só constitui um direito mas também uma obrigação" (Aznar, 2005:189).

Para este professor de Filosofia e Jornalismo, da Universidade de Valência, o público, "na medida em que pode escolher e agir, por pouco que seja, também tem uma parte de responsabilidade na tarefa de melhorar a comunicação, de se esforçar para que ela se ajuste mais aos seus valores e princípios éticos" (Aznar, 2005: 189).

Nesta linha de pensamento, entende-se que "não é só pertinente falar de uma ética do jornalista e de uma ética da empresa comunicativa, mas também de uma ética do público, uma ética dos utilizadores da comunicação, dos recetores ou da audiência" (Aznar, 2005:189). O consumo dos media "deve ser, assim, visto”, segundo as palavras de Hamelink, que chega até a formular um decálogo dos deveres do público, "como uma atividade social que implica

144 Wolf, Mauro, La investigación de la comunicación de masas. Críticas y perspectivas, Barcelona, Paidós, 1996, p. 79 
decisões morais e, portanto, a consequente assunção da responsabilidade derivada dessas decisões"145.

Esta ideia de responsabilidade cultural coletiva que se aproxima do conceito de responsabilidade ecológica, no sentido em que todos somos responsáveis por cuidar do ambiente, remete um pouco para a expressão do escritor Henri Michaux quando ele chama à sua cabeça "as minhas propriedades", na perspetiva de que é nesse território individual e intransmissível que se aloja toda a gama de informação que recebemos e captamos.

Daí, que a qualidade da informação que é dada aos cidadãos é tão importante como a existência de um clima de liberdade e pluralidade para a veicular. Não basta poder publicar e dizer o que se quer - é preciso ter as condições para perceber, aprofundar e verificar a informação que se fornece e observar a sua qualidade. Caso contrário continuaremos a falar de liberdade de informação, mas no plano formal, das aparências, e não da sua substância.

E se assim for, não é apenas a liberdade de informação que estará em causa — é a democracia que estará em risco. Ora, não "deveria haver em cada um de nós - como nos desafia Michael Sandel, professor de Filosofia em Harvard - um voz importuna que perguntasse permanentemente: será que alguém vai também comprar a democracia?"146.

A existência de uma boa informação nas sociedades democráticas e abertas em que habitamos é um bem público de primeira necessidade como a eletricidade ou a água - é impossível viver sem elas. Donde, será normal que a informação jornalística qualificada, exigente e diferenciadora tenha também o seu custo, valor e relevância.

O escritor Gonçalo M. Tavares, que foi diretor por um dia do Diário de Notícias, na edição do $147^{\circ}$ aniversário do jornal, escreveu na ocasião a mesma coisa com as palavras admiráveis com que termino este texto: "um médico responsável, um médico de seres humanos e não um médico de órgãos que ainda estão vivos, logo a seguir à questão: o que é que come? deveria perguntar ao seu paciente: o

145 Hamelink, Cees J. "Ethics for media users", European Journal of Communication, Vol. X, n ${ }^{\circ}$ 4, p. 504, citado por Hugo Aznar na obra Comunicação responsável. A auto-regulação dos media, Porto Editora, 2005, p. 189

146 A frase foi primeiramente citada por Thomas Friedman, num texto intitulado "Corporations on Steroids", publicado no The New York Times de 4/02/2000. Bill Kovach e Tom Rosenstiel recuperam a expressão de Michael Sandon e inserem-na no livro, Os elementos do jornalismo. 
que é que lê? e que imagens é que vê habitualmente? o médico que se preocupa com a saúde do seu paciente, tal como aconselha alimentos e hábitos, poderia aconselhar filmes, livros, fotografias, concertos e artigos de jornal”147.

147 Editorial do $D N, 29 / 12 / 2010$, "Das leituras e da medicina", p. 8 


\section{BIBLIOGRAFIA}

AZNAR, Hugo, Comunicação responsável. A auto-regulação dos media, Porto Editora, 2005.

CARDOSO, Gustavo, "Da comunicaçãoo de massa para a comunicação em rede", in Media, redes e comunicação. Futuros presentes, Coord: Cardoso, Gustavo; Cádima, Francisco Rui; Cardoso, Luís Landerset, Quimera, 2009.

DEBORD, Guy, A sociedade do espetáculo, Mobilis in mobili, Lisboa, 1991

DEBRAY, Régis, O Estado sedutor. As revoluções midiológicas do poder, Editora Vozes, Petrópolis, 1994.

KOVACH, Bill; ROSENSTIEL, Tom, Os elementos do jornalismo, Porto Editora, 2004.

LACOUTURE, Jean, "A História imediata", in A Nova História (dirigida por Jacques Le Goff, Roger Chartier, Jacques Revel), Almedina, 1990.

LÓPEZ, Gabriel Galdón, Desinformação e os limites da informação, Folhas \& Letras, Lisboa, 2003.

PICARD, Robert, Value creation and the future of news organizations: why and how journalism must change to remain relevant in the twenty-first century, Media XXI, Lisboa, 2010.

RODRIGUES, Adriano Duarte, Estratégias de comunicação, Presença, 2001.

SERRANO, Pascual, Desinformación. Cómo los médios ocultan el mundo, Ediciones Península, Barcelona, 2009.

Wolton, Dominique, Pensar a comunicação, Difel, Lisboa, 1999.

\section{Conferência}

Why journalists deserve low paid, Robert Picard, Conferência apresentada no Reuters Institute for the Study of Journalism, University of Oxford, 6 de Maio de 2009.

\section{Jornais}

Courrier International, no 179, Janeiro, 2011-04-21

Diário de Notícias, 29 Dezembro de 2010

El País, 24 e 25 de Fevereiro de 2010.

Público, 25 de Fevereiro, 2010

Expresso, 26 de Fevereiro de 2010. 
ECONOMIA E CRISE 
(Página deixada propositadamente em branco) 


\section{A Crise atual do capitalismo: CRISE ESPERADA E QUASE PROGRAMADA ${ }^{148}$}

1. Toda a construção liberal assenta na ideia de que o melhor dos mundos se atinge, graças à mão invisível inventada por Adam Smith, deixando funcionar o mercado para que a taxa de lucro possa crescer, e, com ela, o investimento, o crescimento económico e o bem-estar para todos.

Este otimismo dos clássicos ingleses acerca das possibilidades de crescimento sem limites e da melhoria generalizada das condições de vida vinha reforçado pela confiança na Lei de Say, segundo a qual não são possíveis crises de sobreprodução generalizadas, e pela convicção de que, em virtude de leis naturais, os salários nunca poderiam, duradouramente, ultrapassar o valor correspondente ao mínimo de subsistência.

Este o enquadramento que justificava o paraíso liberal (o mesmo dos neoliberais dos nossos dias).

A verdade, porém, é que Malthus e depois Marx, cada um à sua maneira, vieram mostrar o que a vida confirmaria: as crises cíclicas de sobreprodução são inerentes ao capitalismo. Perante a evidência da Grande Depressão, o próprio Keynes reconheceu que, nas sociedades capitalistas, as situações de pleno emprego são raras e efémeras.

\footnotetext{
148 Este artigo foi escrito originariamente para um livro de homenagem ao Professor Eros Roberto Grau, Professor Titular Jubilado da Faculdade de Direito da USP, que deverá vir a público em São Paulo (Brasil) durante este ano de 2012. Utilizo neste texto reflexões inseridas no livro As Voltas que o Mundo Dá... Reflexões a Propósito das Aventuras e Desventuras do Estado Social, Edições Avante, Lisboa, 2010 (editado posteriormente no Brasil, com algumas alterações, pela editora Lumen Juris, Rio de Janeiro, 2011) e desenvolvidas, no momento em que escrevo esta nota (início de maio de 2012), em outro livro que entretanto publiquei: A Crise do Capitalismo: Capitalismo, Neoliberalismo, Globalização, Lisboa, Página a Página, 2012.
} 
A crise que agora abala o mundo é, pois, mais uma crise do capitalismo, uma "crise estrutural do capitalismo". ${ }^{149}$

2. Os factos dão razão ao velho Keynes, que, há mais de 50 anos, advertia para os perigos de paralisação da atividade produtiva em consequência do aumento da importância dos mercados financeiros e da finança especulativa.

Talvez por isso a ideologia dominante se tenha apressado a decretar a "morte de Keynes”, 'sacrificado' no altar dos deuses do neoliberalismo. Desmantelada a regulamentação da atividade bancária e financeira, o capital financeiro ficou inteiramente livre para estabelecer o seu império, com a cumplicidade ativa de uma regulação amiga do mercado.

A ação do capital financeiro especulador acabou por anular as políticas nacionais de regulação das taxas de câmbio, uma vez que as autoridades competentes de muitos países ficaram sem meios para se defender eficazmente da ação dos especuladores. Basta recordar que o montante das reservas detidas pelos bancos centrais de todo o mundo (principal meio de defesa das moedas nacionais) é sensivelmente igual ao montante das transações diárias no mercado cambial (em grande parte puramente especulativas).

Por outro lado, o poder político do capital financeiro desmantelou todas as estruturas e mecanismos de regulação e de controlo da atividade financeira, que vinham dos tempos do combate à grande depressão dos anos 1930, a primeira grande crise do capitalismo marcada pelo predomínio do capital financeiro e pela especulação financeira.

2.1. A aceleração do processo de inovação financeira traduziu-se, nomeadamente, no desenvolvimento dos mercados de produtos financeiros derivados. Chamam-lhe produtos para criar a ilusão de que resultam de uma qualquer 'indústria' (também se fala da indústria bancária...) ou de outra atividade produtiva, mas essa é, a todas as luzes, uma designação falsa, enganadora e não inocente.

149 Cfr. G. DUMÉNIL e D. LÉVY, The Crisis..., cit. 
Criados como instrumentos de gestão dos riscos inerentes à instabilidade das taxas de juro e das taxas de câmbio, estes 'produtos' transformaram-se de imediato em instrumentos destinados apenas a alimentar as 'apostas' na bolsa (o grande casino do capital financeiro), dada a pequena percentagem do capital investido em relação aos ganhos possíveis, e revelaram-se um novo e poderoso fator de instabilidade dos mercados financeiros. ${ }^{150}$

Trata-se de produtos virtuais, cujo valor global se calcula em cerca de mil biliões de dólares (o equivalente a vinte anos da produção mundial!), mal conhecidos, que não têm qualquer relação com a economia real e com as atividades produtivas (criadoras de riqueza). É capital puramente fictício, cujo valor é fixado em função dos ganhos que os 'apostadores' prevêem que podem obter, chamando a si uma parte significativa da riqueza criada pela economia real. Estes 'produtos', cada vez mais sofisticados, servem apenas para ganhar dinheiro com a especulação, atraindo bancos, seguradoras, sociedades gestoras de fundos de investimento e de fundos de pensões.

O recurso abusivo à sua emissão e comercialização conduziu rapidamente à manipulação e à instabilidade dos 'mercados financeiros', porque os contornos e os riscos que esses 'produtos' incorporam nem sempre são facilmente identificáveis, mesmo pelos habituais frequentadores deste 'casino' (como os bancos), que compram muitas vezes 'produtos financeiros' tão esotéricos que não sabem exatamente o que estão a comprar.

Na última década do século xx, o volume das transações sobre os mais perigosos destes 'produtos', os chamados over-the-counter derivative markets, aumentou de 24, 6 mil milhões de dólares em 1992 para 94, 6 mil milhões de dólares em 1999 (um aumento de quase 285\%!). O Relatório Podimata (aprovado pelo Parlamento Europeu em fevereiro/2011) salienta que, em termos globais, o volume das transações financeiras, muitas delas implicando a exposição em elevado grau de capitais alheios nos 'jogos de casino', aumentou sempre ao longo da década que terminou em 2007, em especial devido ao incremento das transações sobre produtos derivados, tendo atingido neste ano um valor igual a 73, 5 vezes o PIB nominal mundial. ${ }^{151}$

150 Para uma visão um pouco mais ampla deste processo de inovação financeira, ver A. J. AVELÃS NUNES, O Crédito..., cit., 201-239.

151 Cfr. Relatório Podimata, 5. 
2.2. Os especialistas avisaram que este fenómeno (completamente alheio às necessidades da economia real), para além de expor as instituições financeiras aos riscos máximos inerentes à natureza volátil destes 'produtos', tornava muito mais difíceis o controlo pelas autoridades de supervisão e a auditoria das contas daquelas instituições. ${ }^{152}$ Os seus defensores, porém, não se cansavam de proclamar as 'virtudes globais' de tais produtos: "Formas inteiramente novas de instrumentos financeiros tiveram de ser inventadas ou desenvolvidas - derivativos de crédito, títulos lastreados em ativos, futuros de petróleo e congéneres, que criam condições para o funcionamento muito mais eficiente do sistema de comércio mundial". É este o ponto de vista de Alan Greenspan. ${ }^{153}$

Para além dos riscos inerentes à proliferação dos produtos derivados, a liberalização dos movimentos de capitais, ao serviço do objetivo de criar um mercado único do capital à escala mundial, arrastou consigo um conjunto de alterações que vieram potenciar fortemente a ameaça de risco sistémico. ${ }^{154}$

Com efeito, a internacionalização dos mercados de valores mobiliários veio colocar em rede mercados muito diferentes, cada um com as suas regras de funcionamento e os seus riscos específicos, abrindo caminho à propagação contagiosa dos fatores de risco.

Por outro lado, a ausência de controlo dos mercados financeiros e dos movimentos de capitais pelos estados nacionais provocou uma onda sem precedentes de concentrações, de fusões e de aquisições de empresas financeiras, com a redução acentuada do número de bancos (que controlam companhias de seguros e, direta ou indiretamente, outras instituições financeiras, nomeadamente sociedades gestoras de fundos de investimento e de fundos de pensões), a concentração nos maiores deles da parte de leão dos depósitos bancários e a preponderância dos grandes bancos nas operações de fusão e aquisição de empresas do setor financeiro.

Um estudo recente de três investigadores do Instituto Federal Suíço de Tecno$\operatorname{logia}^{155}$ dá-nos conta do grau de concentração do poder económico-financeiro ao nível dos centros de decisão a nível mundial. Partindo da definição de empresas

152 Cfr. J. M. QUELHAS, ob. cit., 442.

153 Cfr. A. GREENSPAN, A Era..., cit., 355 [usamos a tradução brasileira].

154 Para maiores desenvolvimentos, ver J. M. QUELHAS, ob. cit., 439-441.

155 O referido estudo foi divulgado em Zurique em 28.7.2011 e está disponível em http://arxiv. org/abs/1107.5728v2. 
transnacionais adotada pela OCDE, os autores selecionaram 43.060 empresas de entre as registadas no banco de dados Orbis 2007.

Neste conjunto de empresas, detetaram mais de 600 mil participações diretas e mais de um milhão de participações indiretas no capital de outras empresas. De entre elas, apuraram um núcleo constituído pelas 1318 mais poderosas empresas transnacionais, que representam diretamente $20 \%$ do rendimento global.

Uma análise mais fina permitiu-lhes concluir que cada uma destas empresas tem, em média, participações no capital de 20 outras grandes empresas, o que permite a este grupo de 1318 empresas transnacionais deter ou controlar, em conjunto, cerca de $60 \%$ da economia mundial.

Dentro deste grupo, o estudo identificou um núcleo mais restrito de 147 entidades (3/4 das quais são instituições financeiras: bancos, seguradoras, fundos de investimento, fundos de pensões) que dominam grande parte das restantes: menos de $1 \%$ das entidades estudadas controlam $40 \%$ de toda a rede. Acresce que estas 147 entidades nucleares estão ligadas entre si por uma densa teia de participações cruzadas, o que faz delas o verdadeiro 'governo' do mundo capitalista. Ficamos a saber o que são "os mercados" e compreendemos que estes "mercados" não sejam compatíveis com a democracia.

Em outro plano, compreendemos que, neste mundo controlado pelo capital financeiro, falar de concorrência não faz qualquer sentido. E compreendemos também que a concentração do capital se traduziu na supremacia do capital financeiro, que controla os centros de decisão à escala mundial. Fica claro o significado último da tão falada financeirização da economia. E fica claro também porque é que o fenómeno descrito, para além de acentuar a supremacia do capital financeiro sobre o capital produtivo, veio facilitar o contágio dos riscos entre os vários componentes do mesmo grupo, propiciando a convergência e a acumulação do risco em um núcleo mais restrito de centros de decisão. Nisto consiste o risco sistémico: se uma destas entidades entra em colapso, a doença pode transformar-se rapidamente em pandemia à escala global.

2.3. Igualmente relevantes, para a problemática que vimos analisando, são as consequências da desregulamentação da atividade bancária, da atividade seguradora e das atividades que decorrem nos mercados de valores mobiliários. 
A onda de desregulamentação terá começado nos EUA, com a abolição das restrições à definição e exploração das rotas da aviação comercial, obra da Administração Carter. E a onda prosseguiu o seu caminho, até provocar um verdadeiro tsunami desregulamentador, que atingiu outros setores da atividade económica, entre os quais as telecomunicações, os media e os serviços financeiros.

Durante a Administração Clinton, os bancos comerciais e os bancos de investimento (obrigatoriamente separados por força de legislação promulgada na sequência da Grande Depressão) foram autorizados a juntar-se, dando origem aos chamados conglomerados financeiros, verdadeiros supermercados de serviços financeiros. A revogação (em 1999) do Glass-Seagall Act (de 1933) pelo Gramm-Leach-Bliley Act libertou o setor financeiro das 'peias' da regulação introduzida durante o New Deal, permitindo aos bancos comerciais negociar com valores mobiliários e 'investir' na bolsa, isto é, jogar no casino. Também sob a responsabilidade da Administração Clinton, foi adotado (em 2000) o Commodities Futures Modernization Act, que veio libertar de qualquer controlo os produtos financeiros derivados de maior risco.

O chamado princípio da banca universal veio permitir aos bancos alargar a sua atividade para além das áreas tradicionais do 'comércio bancário', tendo-se multiplicado os produtos mistos (bancassurance, v.g.) e tendo-se verificado uma integração crescente dos vários mercados financeiros (banca, seguros, moedas e títulos).

O desenvolvimento acelerado daqueles poderosíssimos conglomerados financeiros veio aumentar enormemente o seu poder (incluindo o seu 'poder político') e veio tornar muito mais complexas e difíceis as atividades de regulação e de supervisão de cada um dos setores de atividade financeira, o que constitui mais um fator a potenciar o risco sistémico.

2.4. Conscientes dos perigos destas políticas, alguns especialistas vinham defendendo o desmantelamento dos conglomerados financeiros, instituindo de novo a separação rigorosa entre bancos comerciais e bancos de investimento e separando claramente a função bancária da função seguradora, impedindo os bancos de exercer atividades próprias das empresas seguradoras. Assim se evitaria, pelo menos, o financiamento das atividades especulativas com o dinheiro dos 
depositantes, que passaria a financiar a concessão de crédito às empresas e às famílias, impulsionando a criação de emprego e de riqueza, em vez de alimentar as rendas do capital financeiro.

Os estudos mais consistentes e mais informados sobre a matéria justificavam os sucessivos alertas para os perigos do risco sistémico inerente à disseminação dos produtos financeiros derivados, no quadro de um mercado financeiro único de dimensões planetárias, onde impera a plena liberdade de circulação de capitais. À semelhança do que a teoria refere para os mercados de oligopólio, também neste mercado financeiro global os operadores tendem a atuar em função daquilo que eles pensam que será o comportamento dos demais operadores. A turbulência causada pela especulação em um dado país ou região tende a propagar-se a todo o sistema financeiro mundial graças ao comportamento mimético dos grandes especuladores. O risco sistémico é, assim, o risco global de desmoronamento do sistema financeiro à escala mundial. A consciência disto mesmo é que dá sentido à tese dos que, há uns anos a esta parte, vêm defendendo que tais 'produtos' ameaçavam transformar-se em "armas de destruição maciça".

Estas 'armas' são livremente produzidas e utilizadas pelos conglomerados financeiros acima referidos. Mais uma razão para justificar a adoção de medidas com vista ao seu desmantelamento. Os governantes de serviço, porém, nada fizeram neste sentido, antes proclamaram a plena liberdade de ação do capital como o valor supremo a acautelar.

3. As crises recorrentes das últimas décadas, com início no crash da bolsa de Nova York em 1967, foram claros anúncios da crise atual.

Um primeiro sinal da crise estrutural do capitalismo foi a rotura unilateral dos Acordos de Bretton Woods por parte dos EUA (agosto/1971) e a chamada crise do petróleo (1973 e 1975), à qual se seguiria uma outra 'crise do petróleo' em 1978-1980. Estes dois episódios, no início e no fim da década de 1970, anunciaram o esgotamento do keynesianismo, apanhado de surpresa pelo aparecimento da estagflação, estranho fenómeno que, contrariando o modelo histórico das crises do capitalismo e o otimismo dos defensores do capitalismo post-cíclico, veio mostrar que as crises cíclicas continuavam a caraterizar a vida do capitalismo e que, no quadro de um capitalismo altamente monopolizado, podiam 
perfeitamente coexistir preços altos, com taxas elevadas e crescentes de inflação, e taxas de crescimento do produto próximas de zero (ou mesmo negativas), acompanhadas de desemprego crescente.

Ficou patente que a capacidade de produção instalada no mundo capitalista era excessiva relativamente ao poder de compra agregado da população e ficou patente também que as grandes empresas monopolistas tinham suficiente poder de mercado para impedir a queda dos preços, mantendo a sua espiral ascendente, com a cobertura da subida dos preços do petróleo.

O alarme foi tal que Henry Kissinger, então ao leme da diplomacia norte-americana, chegou a ameaçar com a intervenção militar dos EUA se os países exportadores de petróleo não aceitassem baixar os preços do ouro negro. A estratégia imperialista de domínio dos circuitos de produção e de distribuição do petróleo e do gás natural tem aqui a sua origem, tendo desembocado na invasão e destruição do Iraque, na ocupação do Afeganistão, na guerra contra a Líbia, na ameaça de guerra contra o Irão, no congelamento da solução do problema do Médio Oriente. É o cheiro do petróleo e não o sangue das vítimas inocentes dos movimentos de protesto no mundo árabe que está a perturbar os dirigentes das potências ocidentais, que sempre apoiaram - e continuam a apoiar - todas as ditaduras dos 'reis do petróleo' e outras ditaduras 'amigas' (algumas impostas aos respetivos povos pelas "democracias ocidentais").

Mas esta crise da primeira metade da década de 1970 trouxe à luz do dia a tendência para a baixa da taxa de lucro, que se vinha observando com clareza, especialmente a partir de meados dos anos 1960, nas mais importantes economias capitalistas (baixa de 33\% no Japão; 30\% nos EUA e 19\% na Alemanha). ${ }^{156}$ E a tendência para a baixa da taxa de lucro é, em última instância, a causa primeira das crises do capitalismo, da dita crise do petróleo e da crise atual, no início da segunda década do terceiro milénio. ${ }^{157}$

No rescaldo das dificuldades da primeira metade da década de 1970, o consenso keynesiano foi substituído pelo chamado Consenso de Washington, o consenso entre os EUA e as agências internacionais relacionadas com a economia (FMI, Banco Mundial e GATT/OMC), que se enquadra na estratégia para travar aquela perigosa tendência no sentido da baixa da taxa de lucro.

\footnotetext{
156 Cfr. P. CARVAlHO, "A Crise..., cit., 95.

157 Sobre este ponto, ver G. DUMÉNIL e D. LÉVY, "The Profit Rate..., cit.
} 
Trata-se de um consenso no sentido de impor ao mundo as 'regras' da globalização neoliberal: a liberdade plena de circulação de capitais; a desregulamentação dos mercados de capitais, incluindo o mercado de divisas; o combate prioritário à inflação e a desvalorização das políticas de promoção do emprego; a privatização das empresas públicas, incluindo as que produzem e fornecem serviços públicos; a adoção de políticas tributárias favoráveis aos muito ricos e aos rendimentos do capital; a rejeição de qualquer ideia de equidade e de quaisquer políticas de redistribuição do rendimento em favor dos titulares de rendimentos mais baixos. Particular atenção mereceram as políticas tendentes à contenção e à redução dos salários reais e dos direitos dos trabalhadores, num mundo em que a mundialização do mercado de trabalho significou um aumento enorme do exército de reserva de mão-de-obra e constituiu um estímulo poderoso à deslocalização de empresas, em busca de mão-de-obra mais barata e sem direitos.

A reaganomics nos EUA e o thatcherismo no Reino Unido marcam, a partir de 1979, o início deste novo ciclo, em que a ideologia neoliberal se confirmou como a ideologia dominante, a ideologia das classes dominantes (mais especificamente, a ideologia do setor dominante das classes dominantes: o setor financeiro).

Em 1987, Alan Greenspan assume o comando do Sistema de Reserva Federal dos EUA, posto em que se mantém até 2006.

Por meados dos anos 1980, as grandes linhas da ideologia neoliberal começaram a dominar o pensamento e a ação dos partidos socialistas e sociais-democratas, sobretudo na Europa, talvez convencidos de que, nas condições da época, o respeito pelo deus mercado era uma condição de 'respeitabilidade' política. Os dogmas neoliberais ganharam novos crentes, que recorrentemente vêm defendendo a sua 'fé' com o inadmissivel 'argumento' thatcheriano de que não há alternativa [There is no Alternative].

A criação da União Económica e Monetária (UEM) em Maastricht (1991), com a moeda única (o euro), o Banco Central Europeu (BCE) e o Pacto de Estabilidade e Crescimento (PEC), é o ponto crítico da submissão da 'Europa' ao espírito do Consenso de Washington.

Os momentos de crise sucederam-se a partir dos anos 1980. Em 1995, a crise que teve o peso mexicano como protagonista fez tremer o sistema financeiro dos EUA e, por reflexo, o sistema financeiro de todo o mundo capitalista. 
Por essa altura, Michel Camdessus (então Diretor-Geral do FMI) escreveu que o mundo é dominado por um poder político sem controlo, à mercê de uma "classe composta por agentes globais que manipulam divisas e ações e dirigem um fluxo de capital de investimento livre, fluxo esse que todos os dias se torna mais importante, praticamente ao abrigo de todos os controlos estaduais". Referindo-se a estes especuladores profissionais, Camdessus não hesitou em afirmar, sem qualquer cerimónia, que "o mundo está nas mãos destes tipos".

E John Major, então Primeiro-Ministro britânico, observava que o jogo dos especuladores assume "dimensões que o colocam fora de qualquer controlo dos governos e das instituições internacionais". O Primeiro-Ministro italiano, Lamberto Dini, proclamava que "não se pode permitir que os mercados minem a política económica de todo um país". Mais radical foi o Presidente francês Jacques Chirac (outubro/1995): os especuladores são a "a sida da economia mundial".

Apesar deste alarme dos criadores perante o comportamento das suas próprias criaturas, a verdade é que nada foi feito para pôr cobro a esta vertigem libertária, nem sequer com o pretexto de salvar a economia mundial desta espécie de 'sida' que vai diminuindo as suas resistências. Crise após crise, a sida tomou conta da economia mundial, debilitando-a pela via do aumento do desemprego, do trabalho precário e da diminuição dos salários reais e dos direitos dos trabalhadores, do aumento da desigualdade e da exclusão social.

4. A 'guerra' entre os grandes colossos que operam no setor produtivo em mercados cada vez mais alargados e mais 'monopolizados' veio agravar as dificuldades de obter taxas de lucro atrativas nos setores não-financeiros, que vêm laborando com uma percentagem significativa de capacidade ociosa.

Por outro lado, as empresas não-financeiras tornaram-se cada vez mais dependentes dos financiamentos concedidos pela banca, que tem conseguido impor taxas de juro reais consideravelmente elevadas. E este é um dos fatores que tem 'ajudado' a avolumar as dificuldades de obtenção de taxas de lucro 'interessantes' na atividade produtiva, cujas empresas vêm apresentando níveis crescentes de endividamento e um peso crescente (às vezes insuportável) dos encargos financeiros nos custos de funcionamento. 
Com a consolidação da "contra-revolução monetarista" (anos 80 do século xx), ganhou importância relevante um dos aspetos da financeirização das economias capitalistas, que se vinha manifestando desde finais da década de 1960: o aumento acentuado do peso da participação dos investidores institucionais (bancos, companhias de seguros, fundos de investimento, fundos de pensões e mesmo alguns fundos soberanos) no capital acionista das sociedades cotadas em bolsa. ${ }^{158}$

Acresce que uma variada gama de instituições financeiras especializadas passou a gerir, em nome dos seus clientes, enormes carteiras de títulos, cuja dimensão tem aumentado exponencialmente.

Esta nova realidade significou uma mudança de comportamento dos 'investidores' em ações, contribuindo para alimentar a espiral de especulação e para a transformação definitiva das bolsas em bolsas-casino. Em 1999, os valores das novas ações emitidas através da sua venda nas bolsas de Nova York foi de cem mil milhões de dólares. Mas o valor total das ações transacionadas naquelas bolsas atingiu a cifra de 20, 4 milhões de milhões de dólares. Quer dizer: só 1\% dos valores transacionados nas bolsas representam novo capital para as sociedades cotadas em bolsa; 99\% dos negócios bolsistas são jogos de casino. ${ }^{159}$ As bolsas são a alma do capitalismo de casino (expressão que Susan Strange inventou para caraterizar o capitalismo atual).

Nos anos 1950, a regra era ainda a de que a propriedade destes ativos era mantida, nas mesmas pessoas (famílias), durante longos períodos. Atualmente, nos EUA, as ações mantêm-se na titularidade do mesmo 'investidor', em média, por um período que não vai além de um ano. As transações de ações em bolsa representavam cerca de 18\% do capital cotado em bolsa até finais de 1968. Esta percentagem estabilizou à roda dos 20\% na década de 1970, mas atingiu 102\% em 2000, prática que só pode ter-se acentuado desde então.

Novidade é também a lógica de atuação das grandes sociedades cotadas em bolsa e dos seus administradores. As perspetivas sobre a vida e o êxito das empresas a médio prazo e a longo prazo deixaram de interessar aos acionistas-

158 Tomando o exemplo dos EUA, os particulares detinham, nos anos 1950, cerca de $90 \%$ das ações das sociedades cotadas em bolsa. No final dos anos 1970, essa percentagem baixou para 59\% e em 2000 era apenas de 42\%. O resto das ações pertencia aos referidos investidores institucionais, que respondiam por cerca de $3 / 4$ das transações em bolsa. Cfr. J. CROTTY, ob. cit., 274.

159 Cfr. M. KELLY, ob. cit., 33-35. 
-investidores-especuladores (que são tudo menos empresários). Especializados na arte de "enriquecer a dormir" (na expressão de François Miterrand, há uns anos atrás), o negócio deles são os jogos de casino. A sua preocupação fundamental é a de garantir, a curto prazo, a valorização do capital acionista, passando para segundo plano a saúde económica das empresas do setor produtivo, assim transformadas em meras fichas dos jogos de casino.

O capital financeiro descobriu um modo autónomo de ganhar dinheiro, à margem (e à custa) do setor produtivo. Para tanto, as 'metas' atribuídas pelos donos do capital aos gestores profissionais das sociedades cotadas em bolsa passaram a traduzir-se na garantia de elevados rendimentos financeiros a curto prazo e na distribuição pelos acionistas-investidores dos máximos dividendos possíveis em cada exercício. Este é um caminho que privilegia a ótica do curto prazo e desvaloriza a ótica de médio e longo prazos, uma lógica que pode ajudar a compreender o fenómeno de 'desindustrialização' que se vem registando, perigosamente, nos EUA e na Europa.

Em certas condições, tais resultados só são possíveis através do recurso sistemático à fraude em grande escala, através da falsificação dos balanços e da difusão de informação viciada, práticas criminosas que estiveram na ordem do dia no último quarto de século, dando origem (quando conhecidas...) a enormes escândalos, que vieram desfazer o mito da transparência, da racionalidade e da eficiência dos mercados financeiros regulados e afetaram negativamente a honorabilidade das mais 'distintas' empresas de contabilidade e de consultadoria financeira (basta recordar a Arthur Anderson, que desapareceu com o escândalo da ENRON) e das 'sagradas' agências de rating, todas elas comprometidas até à medula com as instituições financeiras e com os gestores das grandes empresas neste jogo de falsidades. ${ }^{160}$

Os gestores profissionais passaram a ter interesse direto na instrumentalização das empresas que gerem ao serviço dos especuladores, entre os quais se incluem. Com efeito, eles são pagos em função dos resultados obtidos no cumprimento das metas fixadas pelos grandes acionistas-investidores-especuladores,

160 Nos EUA, o Congresso, alertado para a situação, nada fez para pôr cobro à fraude, porque "as indústrias financeiras e de contabilidade estão entre os maiores contribuintes para as campanhas dos políticos de Washington, numa época em que as eleições são obscenamente caras". (J. CROTTY, ob. cit., 276) 
maximizando os ganhos financeiros a curto prazo. E são pagos (ordenados e prémios), em grande parte, mediante a entrega de ações das sociedades que administram. ${ }^{161}$

Há alguns anos atrás (ao longo da década de 1970) a doutrina dominante garantia que os top managers não serviam a lógica do capital, gerindo as empresas dotadas de alma como verdadeiros servidores do interesse público. Proclamou-se mesmo que esta revolução dos gerentes tinha transformado o capitalismo em socialismo, anulando o socialismo como alternativa ao capitalismo. Pois bem. Os gerentes deixaram de ser 'revolucionários', e, como grandes acionistas-investidores-especuladores, apostam agora, por todos os meios (incluindo as práticas criminosas), na obtenção de ganhos de capital a curto prazo, associados à especulação bolsista. E o estado ajuda, tornando o 'jogo' mais atraente: as mais-valias ganhas na bolsa ou não são tributadas ou pagam impostos muito inferiores aos que incidem sobre os lucros da atividade produtiva.

Envolvidas nesta teia de interesses especulativos, as empresas dos setores não-financeiros deixaram de se autofinanciar (com uma parte dos lucros não distribuídos), e, muitas vezes, são 'empurradas' para situações de sobreendividamento (o que aumenta a conta dos juros a pagar à banca) para que os seus gestores possam falsificar os balanços e manipular os 'mercados'. E os dividendos que distribuem prodigamente por acionistas (incluindo bancos e outras instituições financeiras) e gestores vão direitinhos para a especulação financeira (preferencialmente em paraísos fiscais, para manter o 'segredo dos negócios' e fugir ao fisco). À escala mundial, é este também o destino de excedentes de capital que não encontram no setor produtivo oportunidades de investimento tão lucrativo como a especulação financeira.

Assim se alimenta o processo de financeirização, a subordinação do capital produtivo ao capital financeiro puramente especulativo. Em última instância, a lógica do capital financeiro privilegia a obtenção de ganhos da especulação a curto prazo e desvaloriza os planos de investimento a médio prazo e a longo prazo, ficando em causa o financiamento adequado do investimento produtivo e da inovação, com a consequente menor criação de emprego e maior pressão

161 Segundo dados colhidos em J. CROTTY (ob. cit., 274), os honorários dos top managers aumentaram, nos EUA, mais de 300\% entre 1970 e 1999, período durante o qual a parte paga em ações da própria empresa passou de $22 \%$ para $63 \%$. 
para cortar nos custos salariais, na tentativa de compensar o aumento dos encargos financeiros das empresas.

5. Entretanto, o processo de inovação financeira continuou a fazer o seu caminho, sem qualquer controlo.

A progressiva liberalização e desregulamentação dos mercados financeiros, juntamente com a absoluta liberdade de circulação de capitais, abriram de par em par as portas da especulação e a especulação ameaça afundar a economia, à escala mundial, como é próprio deste mundo 'globalizado'.

Sabe-se hoje que os receios de uma crise financeira mundial já tinham chegado à reunião do G7 de fevereiro/2007. Nela foi abordada a eventual necessidade de regulamentar a atividade dos chamados hedge funds. Estes são fundos de investimento puramente especulativos, inteiramente desregulados, que operam à escala mundial, muitas vezes com sede em off-shores, que escapam às regras da transparência e ao controlo das autoridades de supervisão, atuando com base em estratégias de investimento que buscam a máxima rentabilidade investindo em 'produtos' de alto risco. Constituem, por tudo isso, elementos fortemente desestabilizadores do sistema financeiro e propagadores de elevado potencial das crises financeiras.

Os mais avisados já então admitiam que o colapso de um deles poderia arrastar consigo uma crise mundial de grandes dimensões. Mas os 'donos' do 'casino' (com destaque para os EUA e o Reino Unido, que constituem o ninho acolhedor de cerca de dez mil hedge funds) opuseram-se a qualquer intervenção. A roleta continuou a rodar, até que a crise rebentou. ${ }^{162}$

Os apóstolos das liberdades do capital sempre proclamaram, aliás, o seu carinho por estes fundos de investimento geradores de "altos lucros financeiros", capazes de atrair "um grande aparato de pessoas e de instituições altamente qualificadas". E Alan Greenspan - que vimos citando - sublinha que "as estratégias

162 Reunindo dados de Van Hedge Fund Advisors International, Inc. (colhidos em http://www. hedgefund.com), J. M. QUELHAS (ob. cit., 516) mostra que no período entre 1988 e 2002, o número de hedge funds aumentou de 1373 para 7500, passando o valor dos ativos geridos por estes fundos, no mesmo período, de 42 mil milhões de dólares para 650 mil milhões de dólares. Esta tendência não abrandou, pelo menos até finais de 2007. 
de investimento dos hedge funds continuam a ser úteis para a eliminação de spreads anormais nos mercados e, talvez, até para a superação de muitas ineficiências".

O gurú do neoliberalismo sabe que nem sempre a realidade sustenta o seu otimismo. Cita mesmo o caso de um dos mais 'ilustres' destes fundos, cujos administradores (entre os quais dois economistas americanos galardoados com o Prémio Nobel da Economia) "se transformaram em jogadores compulsivos, fazendo grandes apostas que tinham pouco que ver com o seu plano de negócios original". Resultado: "Em 1998, a LTCM [o tal hedge fund] perdeu as calças" (a expressão é de Greenspan), sendo os prejuízos absorvidos por empresas seguradoras, fundos de pensões e instituições semelhantes. ${ }^{163}$

Apesar disso, Greenspan regozija-se pelo facto de que tais fundos "não estão sujeitos a qualquer regulamentação pelo estado", fazendo votos para que continuem assim, porque, segundo ele, "os hedge funds ["vibrante setor trilionário, dominado por empresas americanas"] e os fundos de private equity parecem representar as finanças do futuro".

Para salvaguarda do futuro, Greenspan insiste em que "qualquer restrição normativa às estratégias e às táticas de investimento dessas entidades limitaria a assunção de riscos, que é parte integrante da contribuição dos hedge funds para a economia global e, principalmente, para a economia dos Estados Unidos. Por que circunscrever o voo das abelhas polinizadoras de Wall Street?”, pergunta ele.

O esforço 'teorizador' de Greenspan continua: "A inovação é tão importante para nossos mercados financeiros globais quanto para a tecnologia, para os bens de consumo e para a assistência médica. Para acompanhar a expansão da globalização, o nosso sistema financeiro precisa de manter a sua flexibilidade. O protecionismo [i. é, a regulamentação], qualquer que seja o pretexto, político ou económico, seja qual for o seu impacto sobre o comércio ou sobre as finanças, é receita certa para a estagnação económica e para o autoritarismo político". ${ }^{164}$

O Sr. Alan Greenspan, o grande apóstolo da desregulamentação (que se define a si mesmo como "defensor ferrenho do livre funcionamento dos mercados"165),

163 Cfr. A. GREENSPAN, A Era..., cit., 357-359.

164 Cfr. A. GREENSPAN, A Era..., cit., 363. Levando a sério as considerações de Greenspan, teríamos de concluir que Reagan, G. W. Bush (e talvez até Pinochet) e os seus Governos foram exemplos de democracia.

165 Cfr. A. GREENSPAN, A Era ..., cit., 359. 
sempre defendeu, como Presidente do FED, que quanto mais liberdade para o capital financeiro melhor para os negócios (e melhor para o mundo). O seu estímulo e o seu aplauso como 'papa' do mundo financeiro facilitaram a revogação (em 1999) do Glass-Steagall Act, deixando os bancos livres para a especulação. ${ }^{166}$ A onda liberalizadora e desregulamentadora abriu as portas do casino aos bancos, e estes, como jogadores compulsivos, 'queimaram' no jogo, criminosamente, o dinheiro dos depositantes.

As suas responsabilidades foram-lhe recordadas numa Comissão do Congresso, perante a qual, já em plena crise, Greenspan prestou declarações. "O senhor disse-lhe o Presidente da Comissão - tinha autoridade para evitar práticas irresponsáveis que conduziram à crise dos empréstimos subprime. Foi avisado por muita gente para atuar nesse sentido. Agora a nossa economia como um todo está a pagar o preço". ${ }^{167}$

Na sequência do interrogatório, o Congressista recordou afirmações públicas de Greenspan defendendo as teses mais fundamentalistas do neoliberalismo: "não é necessária qualquer regulação pública", mesmo quando se trata de "transações de produtos derivados fora de bolsa", porque "nada na regulação levada a cabo pelo estado a torna superior à regulação do mercado”. E perguntou-lhe se se sentia pessoalmente responsável pelo que aconteceu. Greenspan não respondeu diretamente e o Presidente da Comissão continuou a citá-lo: "Eu tenho uma ideologia. O meu juízo é que mercados livres e de concorrência são, de longe, o melhor modo de organizar as economias. Tentámos as regulações. Nenhuma delas funcionou minimamente". Como quem diz: eu tenho uma ideologia e atuei em conformidade com ela, porque só o mercado livre resolve os problemas.

Foi a vez de o Congressista insistir: "O senhor acha que a sua ideologia o empurrou para tomar decisões que o senhor gostaria de não ter tomado? (...) O senhor enganou-se?" Resposta de Greenspan: "Eu cometi um erro ao presumir que os interesses próprios de organizações, especificamente bancos e outras, eram tais que constituíam o modo mais capaz de proteger os seus próprios acionistas e as suas ações nas empresas. (...) Na realidade, um pilar crítico da concorrência e do mercado livre quebrou. E penso que isso me chocou. Ainda não compreendi

166 Cfr. A. GREENSPAN, A Era..., cit, 362/363.

167 As citações relativas a esta sessão no Congresso dos EUA foram colhidas em J. CASSIDY, ob. cit., 4-6. 
inteiramente porque é que isso aconteceu, e, obviamente, na medida em que eu veja claro o que aconteceu e porquê, eu mudarei os meus pontos de vista".

Em outro momento das suas declarações, Greenspan afirmou: "Encontrei uma falha no modelo que eu considerava como a estrutura crítica de funcionamento que define o modo como o mundo funciona, se posso dizer assim”. Tentando concluir, o Presidente da Comissão interpelou Greenspan: "Por outras palavras, o senhor acha que a sua concepção do mundo, a sua ideologia, não era correta”? Ao que Greenspan respondeu: "Precisamente". Mas não deixou de salientar que ter uma ideologia é, a seu ver, uma condição indispensável para lidar com a realidade e que, para existir, precisamos de uma ideologia ("To exist, you need an ideology").

É um diálogo curioso e elucidativo. Ele mostra que se entregou à raposa a guarda da capoeira, confiando a regulação ao defensor mais radical da desregulação. Ele mostra também quanto é urgente uma reflexão séria sobre esta problemática por parte de todos aqueles que, à 'esquerda', em nome do pragmatismo, da 'modernidade', da 'respeitabilidade' como políticos capazes de bem gerir o capitalismo, vêm procurando apagar a ideologia (com o argumento TINA de que não há alternativa...), aceitando, como 'comandos' inevitáveis, os dogmas da ideologia neoliberal.

Como se diz atrás, há anos que os especialistas na matéria chamam a atenção dos responsáveis políticos para o perigo de os novos produtos financeiros, nomeadamente os produtos derivados, se transformarem em "armas de destruição maciça”. O 'desregulador-mor' não ignorava estes estudos. Mas, como todos os grandes do mundo, há-de ter pensado que, nas guerras, quem costuma morrer é o povo...

O que é verdade é que nas cimeiras do G20 de 2008 (Washington) e de 2009 (Pittsburg) se falou da necessidade de reforçar os mecanismos de regulação e de supervisão do setor financeiro. Mas não se foi além da conversa. ${ }^{168}$ Quando o 'negócio' faliu, chamaram o povo para os salvar, e o povo está a pagar a fatura.

No Relatório da Comissão de Inquérito à Crise Financeira, entregue ao Presidente Obama em janeiro/2011, reconhece-se que, antes de a crise rebentar, não faltaram os sinais anunciadores dela, sinais que foram ignorados ou mini-

168 Informação colhida no chamado Relatório Podimata, cit., 5. 
mizados. O FED nada fez para impedir os bancos de conceder empréstimos de alto risco, deixando-os, irresponsavelmente, 'envenenar-se' com ativos tóxicos: "os reguladores tinham o poder necessário para proteger o sistema financeiro", mas "escolheram não o utilizar", diz o Relatório. Nele se denunciam as pressões das instituições financeiras sobre os decisores políticos e sobre as entidades reguladoras, feitas à custa de milhares de milhões de dólares pagos às sociedades de lobbying e pagos aos políticos para financiar as suas campanhas eleitorais. A ação das agências de rating é igualmente apontada como um dos fatores essenciais da crise. ${ }^{169}$

Hoje é por demais evidente a pesada responsabilidade desta política neoliberal de fomento e garantia das liberdades do capital financeiro no desencadear da grave crise financeira que anunciou e desencadeou a crise económica profunda e global que hoje se vive no mundo capitalista: a progressiva desregulamentação dos mercados financeiros, a liberdade absoluta de circulação de capitais à escala mundial e a deficiente (ou cúmplice) atuação das entidades reguladoras e das sociedades (privadas) de rating são alguns dos fatores que conduziram o 'casino' à bancarrota.

Esta crise veio tornar evidentes as consequências dramáticas do capitalismo de casino, da predominância do capital financeiro sobre o capital produtivo, do corte entre a especulação financeira e a economia real, pondo em xeque, de modo irrecusável, os cânones do neoliberalismo.

6. Uma das mais celebradas invenções da 'inovação financeira' é a titularização de créditos, cuja importância cresceu exponencialmente a partir do início da década de 2000 (em 2007, o valor envolvido correspondia a pouco menos de metade do produto mundial), fazendo dela um dos instrumentos da financeirização do sistema capitalista, que se acentuou a partir dos anos 80 do século xx.

A titularização de créditos está na base da crise financeira que começou nos EUA no setor do crédito hipotecário. Vendiam-se habitações a crédito (garantido por hipoteca sobre o prédio vendido) a quem não tinha capacidade financeira

169 Cfr. Le Monde Diplomatique (ed. port.), março/2011, 8. Tem inteira razão Serge Halimi: "os responsáveis políticos comportam-se demasiadas vezes como marionetas que se preocupam, sobretudo, em não incomodar o festim dos banqueiros" (Le Monde Diplomatique, maio/2011, 1). 
para as pagar e a quem as comprava apenas com fins especulativos (ganhar, a curto prazo, com a valorização dos imóveis). De seguida, emitiam-se novos títulos obrigacionistas, assentes na hipoteca.

Falam alguns autores de financeirização do rendimento pessoal dos indivíduos ou famílias que recorriam ao crédito bancário (para a compra de casa, mas também para a educação, a saúde, etc.), com o objetivo de extrair dele, diretamente, um ganho financeiro (puramente especulativo). A esta prática chama Costas Lapavitsas "expropriação financeira". ${ }^{170}$

A voragem era tal que, enquanto o preço das habitações foi aumentando, muitos dos clientes dos bancos que tinham adquirido as suas casas a crédito eram encorajados a constituir sobre elas uma nova hipoteca, para receberem mais crédito ao consumo, que iria ser igualmente titularizado, numa espiral vertiginosa.

A banca começou a vender pacotes desses produtos derivados (títulos obrigacionistas negociáveis), assentes em créditos hipotecários menos fiáveis, 'produtos' que foram adquiridos por investidores institucionais (nomeadamente os atrás referidos hedge funds), tendo-se espalhado por instituições financeiras de todo o mundo. Disperso o risco pela grande quantidade de titulares de unidades de participação nestes fundos, os inventores deste 'jogo' talvez tenham pensado ter resolvido a quadratura do círculo, acreditando que poderiam vender sem limitações esses créditos titularizados, com base na ilusão de que a dispersão dos riscos os fazia desaparecer. ${ }^{171}$

O dinheiro disponível excedia a capacidade de investimento na economia real, pelo que os grandes gestores da banca se convenceram de que podiam ganhar muito dinheiro emprestando-o ou lançando-o no 'jogo' sem acautelar minimamente o seu reembolso. E, se bem o pensaram, melhor o fizeram: alguns bancos chegaram a emprestar o equivalente a trinta vezes o montante dos seus depósitos. Para tanto, montaram um 'esquema' assente nos chamados empréstimos subprime, assim designados porque concedidos sem respeitar as regras técnicas sobre as garantias exigidas a quem recorre ao crédito, no que toca à sua capacidade para cumprir atempadamente os encargos da dívida (juros e amortização do capital). Muitos desses empréstimos foram, aliás, designados

170 Cfr. C. LAPAVITSAS, "Financialised Capitalism", op. cit., p. 115.

171 A verdade é que, no período entre 2004 e 2006, foram titularizados 79, 3\% destes créditos hipotecários de baixa qualidade. Cfr. C. LAPAVITSAS, últ. ob. cit., 117. 
empréstimos tipo ninja, i. é, empréstimos concedidos a quem não tinha rendimentos, nem emprego, nem ativos - "No Income, no Job or Asset". ${ }^{172}$

Num país em que o endividamento das famílias, graças ao 'estímulo' do crédito ao consumo, representa $120 \%$ do rendimento disponível, a fantasia desfez-se quando, em meados de 2006, os preços das habitações começaram a baixar e, no primeiro trimestre de 2007, cerca de $15 \%$ das pessoas (famílias) que tinham sido atraídas pelo crédito fácil deixaram de pagar os seus encargos (mais de dois milhões de famílias). Foi o início da subprime crisis, com a falência do subprime market, no qual se negociavam produtos financeiros derivados do crédito de baixa qualidade concedido a empresas de construção civil e a compradores de casa (subprime credit).

Já em 2004 o próprio FBI chamava a atenção, publicamente, para o que designava "uma epidemia de fraudes hipotecárias". As entidades reguladoras fizeram de conta que não viam nada e a Administração de George W. Bush não só não fez nada como deu a entender, com suficiente clareza, que nada faria. ${ }^{173}$

O risco afetou rapidamente não só os bancos mas também as companhias de seguros que tinham feito o seguro (e até o resseguro) dos créditos concedidos, bem como os fundos de investimento controlados por aqueles, cujas dificuldades aumentaram porque o valor de mercado dos prédios hipotecados foi baixando progressiva e acentuadamente (entre 5\% e 10\% em 2007; em maior escala ainda em 2008), por excesso de oferta e baixa da procura. Quando os produtos derivados resultantes da titularização dos créditos hipotecários, embora teoricamente negociáveis, deixaram de ser negociados na prática, porque ninguém os queria,

172 Um exemplo esclarecedor da fúria especulativa, à margem das regras mais elementares das práticas bancárias, é relatado por Richard Cohen em The Washington Post, tendo como personagem a Sra Marvene Halterman, de Avondale, Arizona. "Aos 61 anos, após 13 anos desempregada e pelo menos outros tantos vivendo da previdência social, ela conseguiu uma hipoteca. Conseguiu-a apesar de, em certa ocasião, viverem 23 pessoas em sua casa (175 metros quadrados, uma casa de banho) e em algumas edículas caindo aos pedaços. Ela conseguiu pelo imóvel 103 mil dólares, quantia que excedia em muito o valor da casa. (...) A casa da $\mathrm{Sr}^{\mathrm{a}}$ Halterman nunca fora exatamente uma vitrine - uma vez fora intimada pela prefeitura por causa de todo o entulho (roupas, pneus, etc.) no quintal. Contudo, uma instituição financeira local, com o nome de fachada Integrity Funding $L L C$, deu-lhe uma hipoteca, avaliando a casa em cerca do dobro do preço pelo qual uma propriedade vizinha semelhante fora vendida... A Integrity Funding vendeu depois à Wells Fargo E Co., que o vendeu ao HSBC Holding PLC, que então o empacotou junto com milhares de outras hipotecas de risco e ofereceu o mingau indigesto a investidores. A Standard and Poor's e a Moody's Investors Service fizeram averiguações, como deveriam fazer, e atribuíram a notação triplo-A (AAA), i. é, totalmente isento de riscos" (apud James GALBRAITH, Introdução, cit., 10/11).

173 Informação colhida em James GALBRAITH, Introdução, cit., 9. 
chegou-se ao fim do caminho: a banca do 'casino' ficou sem fundos; as famílias estavam mais endividadas (muitas perderam as casas) e as taxas de poupança baixaram dramaticamente. ${ }^{174}$

Em pouco tempo a crise instalou-se no mercado interbancário, o mercado em que os bancos emprestam dinheiro uns aos outros, em regra a prazos muito curtos. Perante a realidade, os bancos deixaram de confiar uns nos outros (porque conheciam bem o lixo que todos tinham acumulado) e deixaram de conceder crédito uns aos outros, o que provocou a diminuição da liquidez, a escassez do crédito e o aumento das taxas de juro.

Em março de 2008, o Bear Sterns (um importante banco de investimentos) entrou em colapso, tendo sido salvo pelo FED, que forçou a sua compra pelo JPMorgan, ao qual teve de conceder, para esse efeito, um empréstimo de 29 mil milhões de dólares. Em 7 de setembro de 2008, o governo americano 'tomou conta' da Fannie Mae e da Freddie Mac (as duas 'estrelas' do crédito hipotecário, que detinham cerca de metade do mercado dos créditos hipotecários), numa operação de salvamento que custou aos contribuintes americanos 200 mil milhões de dólares.

Na tentativa de aumentar a liquidez, o FED injetou milhões de dólares no circuito financeiro, gastou um milhão de milhões de dólares na compra de ativos tóxicos e ofereceu crédito a taxas de juro próximas de zero. Apesar disso, o Lehman Brothers anunciou falência no dia 15 de setembro de 2008. No dia seguinte, a Administração americana decidiu intervir (transformando dívida privada em dívida pública) para salvar o AIG (American International Group), um grupo segurador de créditos, muitos deles assentes em ativos tóxicos. ${ }^{175}$

Por pressão do capital financeiro, o estado capitalista, fiel aos dogmas do neoliberalismo, concedeu todas as liberdades à especulação. Quando o 'negócio' faliu, foi chamado o estado para salvar os especuladores, tendo respondido à chamada com toda a solicitude e determinação, convocando o povo para pagar a fatura. Só os acionistas e os credores do Lehman Brothers perderam o seu dinheiro. Invocando o risco sistémico (que até então ignorara), a Administração

${ }_{174}$ De 9\%/10\% do rendimento disponível nos anos 1970/1980, a taxa de poupança das famílias baixou para 0, 4\% em 2006/2007. Cfr. C. LAPAVITSAS, últ. ob. cit., 118.

175 Segundo a chamada Doutrina Greenspan, as bolhas não podem ser prevenidas, cabendo ao estado resolver o problema a posteriori. E "a prática de Greenspan foi criar uma bolha após outra, até finalmente surgir uma tão vasta que destruiu todo o sistema". Cfr. James GALBRAITH, Introdução, cit., 9/10. 
de G. W. Bush anunciou que não deixaria falir mais bancos, protagonizando a mais dispendiosa intervenção do estado na economia desde os anos trinta, apesar de sempre ter proclamado que a intervenção do estado na economia era uma das marcas do império do mal. Estava inventado o capitalismo sem falências, ao menos para os bancos (e outras instituições financeiras) considerados too big to fail. ${ }^{176}$ As voltas que o mundo dá.... No final de 2008, a crise financeira degenerou em crise económica, que teve o momento mais simbólico no afundamento da General Motors, o símbolo da indústria americana e do poderio americano (ficou célebre o slogan: o que é bom para a GM é bom para os EUA), salva à custa de milhões e milhões de dólares saídos dos bolsos dos contribuintes.

7. Parece até que, desta vez, tudo foi planeado para que a crise acontecesse. Num artigo publicado em L'Express em finais de 2011, até o insuspeito Jacques Attali vem reconhecer que "esta crise foi consequência do enfraquecimento da parte dos salários no valor acrescentado". ${ }^{177}$ Mas a importância do "enfraquecimento da parte dos salários no valor acrescentado" como elemento potenciador de crises de sobreprodução é de há muito conhecida. Marx esclareceu esta questão. E Keynes, à sua maneira, deixou claro que as enormes desigualdades de rendimento não favoreciam o crescimento económico, antes provocariam a insuficiência da procura efetiva, que ele considerava a causa das crises cíclicas próprias do capitalismo.

E, no entanto, a tentativa de travar a tendência para a baixa das taxas de lucro (que a crise de 1973-1975 evidenciara) conduziu, nas últimas décadas, à adoção de políticas sistemáticas de diminuição da parte dos salários no rendimento global e do poder de compra dos salários, apesar de se saber que estas políticas potenciam a ocorrência de crises.

7.1. O pensamento liberal sempre assumiu que a baixa dos salários reais é o elemento indispensável para tornar atrativa a contratação de trabalhadores desempregados e assim inverter o ciclo, abrindo o caminho para que, com base

\footnotetext{
176 Cfr. G. STERN and R. FELDMAN, Too Big to Fail, ob. cit.

177 Citado por A. BARROSO, ob. cit., 16.
} 
no funcionamento do mercado livre, se atinjam situações de reequilíbrio com pleno emprego em todos os mercados e em todos os setores da economia.

Hayek enfatiza este ponto: "o problema do desemprego é um problema de salários". Isto é: a diminuição dos salários reais e salários reais baixos são a condição indispensável e decisiva para se prevenirem e se ultrapassarem as crises, que poderiam ser evitadas se se deixassem funcionar livremente os mercados, nomeadamente o mercado de trabalbo, liberto das 'imperfeições' que o descaraterizam (contratação coletiva, salário mínimo garantido, proteção legal contra os despedimentos sem justa causa, subsídio de desemprego, etc.).

Compreende-se, por isso, que, ao longo das últimas quatro décadas de império neoliberal, os interesses e os atores que estão por detrás da financeirização tenham pressionado (e continuem a pressionar) os governos a adotar as políticas de arrocho salarial (diminuição dos salários reais e diminuição da parte da riqueza criada que cabe aos trabalhadores), bem como as políticas que dão primazia ao combate à inflação (para não ficarem em risco as cotações dos valores mobiliários) e que desvalorizam a promoção do crescimento e do emprego. ${ }^{178}$

Num contexto de acentuado desenvolvimento científico e tecnológico (rapidamente incorporado na atividade produtiva) e consequente aumento da produtividade, tratava-se de fazer reverter os ganbos da produtividade em benefício do capital, impedindo os trabalhadores de beneficiar condignamente da riqueza que criam. ${ }^{179}$

7.2. Em termos globais, a produtividade aumentou, à escala mundial, nos últimos dez anos, cerca de 30\%, enquanto o aumento dos salários não foi além de 18\%.

178 Cfr. P. - A. IMBERT, ob. cit., e M. HUSSON, ob. cit.

179 Hayek condenou violentamente a pretensão dos sindicatos de que os salários devem aumentar tendo em conta os aumentos da produtividade, pretensão hoje geralmente considerada socialmente justa e economicamente vantajosa, de tal modo que mesmo as associações patronais não a atacam em público, por acreditarem que tal seria 'politicamente incorreto'. Para Hayek ao invés, a aceitação daquela pretensão dos sindicatos equivaleria ao reconhecimento do direito de expropriar uma parte do capital das empresas. Vejamo-lo nas suas próprias palavras: "O reconhecimento do direito do trabalhador de uma empresa de participar, enquanto trabalhador, numa quota dos lucros, independentemente de qualquer contribuição que ele tenha feito para o seu capital, faz dele proprietário de uma parte da empresa. Neste sentido, tal exigência é, sem dúvida, puramente socialista e, o que é mais, não baseada em qualquer teoria socialista do tipo mais sofisticado e racional, mas no mais grosseiro tipo de socialismo, vulgarmente conhecido por sindicalismo." Cfr. F. HAYEK, "Unions..., cit., 281ss. 
A 'globalização' aumentou enormemente o número de trabalhadores disponíveis à escala mundial, tendo o exército de reserva de mão-de-obra aumentado também, no quadro europeu, na sequência da implosão da URSS, do desaparecimento da comunidade socialista europeia e da integração de vários dos países da Europa central e de leste na própria União Europeia.

Os especialistas põem em relevo o facto de que "os trabalhadores de todos os países, independentemente do seu grau de desenvolvimento industrial e do sistema social, estão doravante em concorrência entre si, em todos os domínios da economia, com um leque salarial entre um e 50 ou mais". O aumento da concorrência entre os trabalhadores neste novo mercado mundial do trabalho já foi considerado "a principal consequência social da mundialização". 180 Ele é, sem dúvida, um elemento novo na caraterização do capitalismo global, que não existia em 1916, quando Lenine publicou o estudo clássico sobre O Imperialismo, e que precisa de ser analisado à luz da revolução científica e tecnológica do último quarto de século.

Nestas condições particularmente favoráveis ao capital, o referido objetivo foi plenamente conseguido. O aumento da parte do capital na partilha do valor criado pelo trabalho produtivo atingiu mesmo proporções escandalosas. A distorção, em favor do capital, da chamada distribuição funcional do rendimento tem-se traduzido no agravamento da exploração e no empobrecimento relativo (e mesmo absoluto) da grande massa dos trabalhadores, tanto nos chamados 'países ricos' como nos ditos 'países pobres.' ${ }^{181}$

180 Cfr. D. GALLiN, ob. cit., 103.

181 Os trabalhadores continuam, por outro lado, a pagar um dramático "imposto de sangue" (Ignacio Ramonet, Le Monde Diplomatique, ed. port., Junho/2003), traduzido no elevado número de vítimas de acidentes de trabalho e de doenças profissionais. Segundo dados da OIT, todos os anos 270 milhões de trabalhadores são vítimas de acidentes de trabalho e 160 milhões contraem doenças profissionais. Os acidentes de trabalho provocam todos os dias pelo menos 5 mil mortos (mais de dois milhões por ano!). Mesmo num país como a França, todos os anos morrem 800 trabalhadores vítimas de acidentes de trabalho, registando-se cerca de dez feridos por minuto.

Um Relatório da OIT elaborado no âmbito do Dia Mundial da Segurança e Saúde no Trabalbo (28.4.2010) refere que o stress, enquanto doença profissional, atinge gravemente mais de $20 \%$ dos trabalhadores da UE, sendo a causa de mais de metade dos dias de trabalho perdidos.

Neste mundo antropofágico, em estado de guerra civil permanente, há ainda que contabilizar os que morrem de fome e outras vítimas da fome. Há pouco tempo, o Prof. Jean Ziegler, membro do Comité Consultivo do Conselho de Direitos Humanos da ONU, tornava público que, de 5 em 5 minutos, morre uma criança com menos de dez anos; que mil milhões de pessoas são subalimentadas; que todos os dias morrem 47 mil pessoas de fome (Cfr. Público, 4.4.2010). Se a estes juntarmos os que morrem de doenças evitáveis, muitas vezes resultantes da fome, o número de mortos provocados por esta guerra civil é, em cada ano, muito próximo dos mortos causados pela Segunda Guerra Mundial. Este mundo capitalista, agora gerido pela cartilha neoliberal, não é, de verdade, o paraíso... 
Um estudo do FMI, publicado em 2007, mostra que a parte do rendimento do trabalho no rendimento nacional baixou, de forma sistemática, entre 1980 e 2005, no conjunto dos países mais desenvolvidos. ${ }^{182}$

No Relatório sobre o Trabalbo no Mundo/2008, a OIT sublinha que "em 51 dos 73 países para os quais existem dados disponíveis, a parte dos salários no rendimento nacional tem diminuído ao longo dos últimos vinte anos", especificando que "o declínio mais forte da parte dos salários no PIB teve lugar na América Latina e nas Caraíbas (-13 pontos percentuais), seguindo-se a Ásia e o Pacífico (-10 pontos percentuais) e as economias desenvolvidas ( 9 pontos percentuais)".

Um documento de trabalho apresentado na reunião de julho de 2010 do Banco de Pagamentos Internacionais faz uma longa análise crítica deste mesmo fenómeno: "A parte dos lucros é hoje invulgarmente elevada, e a parte dos salários invulgarmente baixa. De facto, a dimensão desta evolução e o leque dos países a que diz respeito não têm precedentes nos últimos 45 anos".

Para o conjunto da UE, a Comissão Europeia regista uma diminuição da parte dos salários de 8, 6\% entre 1983 e 2006 (9, 3\% na França). E, para o conjunto dos países do G7, o FMI aponta, para o mesmo período, uma diminuição de 5, 8\%.

Os dados oficiais mostram que, na UE/15, a parte dos rendimentos do trabalho no rendimento nacional passou de 65\% em 1980 para 49, 4\% em 2005 e 48, 9\% em 2008. Tomando a UE/25, essa percentagem passou de 50, 2\% em 2002 para 48, 5\% em 2008, sabendo-se que, em vários países da UE, entre os quais Portugal, esta percentagem é ainda mais baixa. ${ }^{183}$

Em finais de 2007, alguém tão insuspeito como Alan Greenspan reconhecia que "a parte dos salários no rendimento nacional nos EUA e em outros países desenvolvidos atingiu um nível excepcionalmente baixo segundo os padrões históricos, ao invés da produtividade, que vem crescendo sem cessar." E não escondeu a sua preocupação, invocando que "esta desproporção entre fracos níveis salariais e lucros historicamente muito elevados faz temer um aumento da

182 Cfr. IMF, Finance and Development, junho/2007.

183 Em Portugal, a distribuição mais favorável aos trabalhadores registou-se em 1975: a parte dos rendimentos do trabalho no rendimento nacional atingiu então 59\% (uma cifra modesta, apesar de bastante melhor do que a registada até 1974, durante o salazarismo); em 2002, essa percentagem rondava os 50\%, tendo-se reduzido para 47, 0\% em 2008. De então para cá, baixou e muito. 
animosidade contra o capitalismo e o mercado, tanto nos EUA como em outras zonas do mundo". ${ }^{184}$

É capaz de ter razão. Mas é curioso que Greenspan não tenha sequer aludido ao risco de uma crise grave do capitalismo, como consequência do fenómeno que regista. Talvez porque ele é um fiel da Lei de Say e acredita que as crises de sobreprodução não são possíveis nas sociedades capitalistas...

7.3. Isto significa que os ganhos da revolução científica e tecnológica têm servido, essencialmente, para aumentar os lucros (em especial os lucros especulativos do capital financeiro), quando deveriam ter ajudado à progressiva libertação dos trabalhadores, não só através do aumento dos salários, mas, sobretudo, proporcionando garantias mais sólidas no que toca aos direitos no âmbito da segurança social, melhores condições de vida e de trabalho, redução do horário de trabalho, melhores serviços públicos de educação e de saúde, universais, gerais e gratuitos.

A história do capitalismo adulto mostra que, quando o medo do aumento da "animosidade contra o capitalismo e o mercado" (A. Greenspan) perturbou o sono dos senhores do mundo, estes cederam às reivindicações dos trabalhadores, acreditando que assim os desviavam dos caminhos da revolução anti-capitalista, podendo, por isso, dormir em paz.

E mostra também que o aumento do poder de compra dos trabalhadores (que constituem a grande maioria da população) acompanhou sempre os períodos de crescimento económico e de progresso social. Isto quer dizer que a subida dos salários reais, em resultado da luta das organizações dos trabalhadores, tem constituído, historicamente, um fator de desenvolvimento pelo menos tão importante como o desenvolvimento científico e tecnológico (e o consequente aumento da produtividade), as exportações e o investimento direto estrangeiro.

O grande mérito de Keynes poderá ter residido na sua capacidade de compreender isto mesmo. E, preocupado, acima de tudo, em salvar o capitalismo, fez propostas que estão na base do estado social e do estado-providência.

184 Cfr. Financial Times, 17.9.2007. 
Mas, com a implosão da URSS e da comunidade socialista europeia, a contra-revolução monetarista ganhou novo fôlego, o pensamento único conquistou mais adeptos, a ideologia neoliberal acentuou o seu domínio, e os 'donos' do mundo acreditaram que não havia razão para medos e que, como os vampiros, poderiam comer tudo e não deixar nada.

Sempre tem sido assim: quando as condições objetivas permitem alimentar o sonho de que o capitalismo tem garantida a eternidade, ganha força a tentação reacionária de regressar ao século xvıı e à violência das relações industriais que marcou os primeiros tempos do capitalismo.

Este o sentido das políticas neoliberais - prosseguidas por conservadores, socialistas ou sociais-democratas -, que rejeitaram ou esqueceram a lição de Keynes e apostaram na baixa dos salários reais e na partilha dos ganhos de produtividade em benefício do capital. Estas políticas garantem lucros (e muitos) a curto prazo aos que "vivem do lucro" (para usar a expressão de Adam Smith), mas agravam as contradições dentro do capitalismo como um todo e acentuam os riscos de ocorrência de crises cíclicas. Em obediência aos dogmas do neoliberalismo, semearam ventos; os povos sofrem agora as tempestades.

8. Apesar dos enormes ganhos da produtividade do trabalho (a uma escala sem comparação com os séculos anteriores), decorrentes do desenvolvimento científico e tecnológico e da sua rápida aplicação na esfera da produção, a globalização neoliberal acentuou as desigualdades e condenou à extrema pobreza milhões de seres humanos, espalhando, como uma nódoa, a chaga da exclusão social (a "nadificação do outro", na expressão terrivelmente certeira do cineasta brasileiro Walter Salles), que é uma vergonha deste nosso tempo.

Ainda ninguém conseguiu demonstrar a existência de uma relação positiva entre a flexibilização da legislação laboral e os baixos salários, por um lado, e o aumento da 'competitividade' ou a redução do desemprego, por outro lado. A vida nega todos os dias esta pretensa relação, que não passa de uma criação da ideologia dominante. Keynes (e Marx antes dele) deixou claro que os salários sobem quando o desemprego diminui e diminuem quando o desemprego aumenta, e não o contrário. O desemprego não diminui quando os salários baixam nem aumenta quando os salários sobem, porque - defende Keynes - o nível do 
emprego (e o nível dos salários) depende de um fator externo ao mercado de trabalho: a procura efetiva.

Poucos aceitarão, por isso, que se justifiquem as políticas de baixa dos salários com o argumento de que elas são necessárias para proteger e para relançar o emprego. Elas visam apenas aumentar a parte do capital na riqueza produzida. E os resultados estão à vista, em termos de empobrecimento da grande maioria da população.

O Presidente do Banco Mundial (Robert Zoellick) escrevia, em outubro/2010: "Pela primeira vez na história, mais de mil milhões de pessoas deitam-se todas as noites com a barriga vazia". ${ }^{185}$

Num Relatório da OCDE de finais de 2011 (6 de dezembro) põe-se em relevo o facto de as desigualdades sociais terem aumentado ininterruptamente ao longo dos últimos trinta anos, tendo atingido níveis de rotura: "o contrato social está a desfazer-se em muitos países", recordou o Secretário-Geral daquela Organização, durante a sessão de apresentação do relatório, em Paris.

Segundo dados do FMI (outono/2010), as políticas neoliberais destruíram, em 2009, à escala mundial, 30 milhões de postos de trabalho, dando uma boa contribuição para engrossar o número dos desempregados, que rondará, segundo a OIT (Tendências Mundiais do Emprego - 2011) os 205 milhões em todo o mundo, sendo que 1530 milhões dos que têm trabalho desenvolvem a sua atividade em condições de precariedade.

Considerando pobres aqueles que auferem rendimento inferior a 60\% do salário médio do país onde vivem, 80 milhões de cidadãos da rica UE vivem abaixo do limiar da pobreza (incluindo 19 milhões de crianças), e cerca de 17\% dos europeus não têm recursos suficientes para satisfazer as suas necessidades básicas (dados da Comissão Europeia referentes a 2010).

E o Grupo de Reflexão constituído no âmbito do Conselho Europeu e presidido por Felipe González concluiu que, "pela primeira vez na história recente da Europa, existe um temor generalizado de que as crianças de hoje terão uma situação menos confortável do que a geração dos seus pais". 186

\footnotetext{
185 Citação colhida em Le Monde Diplomatique (ed. port.), outubro/2010.

186 Segundo um estudo da Fabian Society, de finais de 2009, na Inglaterra, as políticas levadas a cabo por conservadores e trabalhistas (de Thatcher a Blair e a Gordon Brown) colocaram o país "perante o risco de regressar a níveis de pobreza idênticos aos da era vitoriana" (The Independent, 30.11.2009). Também aqui, é o regresso ao século xvıII.
} 
É particularmente elucidativa, a este respeito, a análise da realidade americana a partir de 1973 (Administração Nixon) e de 1979 (com o início da reaganomics), realidade que alguém classificou como "depressão silenciosa". ${ }^{187}$

Os salários reais (que subiram sempre entre 1947 e 1973) registam uma baixa significativa a partir deste último ano. O mesmo aconteceu com o rendimento mediano das famílias americanas, sempre crescente no período atrás referido. A partir de então, este indicador só não baixou (manteve-se praticamente estagnado) porque a participação crescente das mulheres no mundo do trabalho permitiu que o salário das mulheres se somasse ao salário dos homens.

No mesmo sentido aponta a evolução registada em matéria de distribuição do rendimento: a partir do início da década de 1970 baixou o rendimento familiar médio dos $80 \%$ das famílias americanas com rendimentos mais baixos (baixas de quase $15 \%$ para os $10 \%$ mais pobres), ao mesmo tempo que aumentava (mais de $16 \%$ ) o rendimento dos $10 \%$ mais ricos (aumento de 23 , $4 \%$ para os $5 \%$ mais ricos e de quase $50 \%$ para os do topo da tabela - 1\%).

Em 1979, esta elite dos 1\% mais ricos arrecadava, após o pagamento dos impostos, o mesmo rendimento que cabia aos 20\% de rendimentos mais baixos; em 2007, a mesma elite arrecadava tanto como os $40 \%$ do fundo da tabela; a percentagem do rendimento nacional que cabe a estes 'eleitos' (após pagamento dos impostos) passou de 8\% em 1979 para 17\% em 2007. ${ }^{188}$ Em finais de 2009, os 20\% mais pobres dos americanos auferiam rendimentos inferiores ao nível oficial da pobreza. ${ }^{189}$ E o Censo de 2010 revelou, segundo os dados vindos a lume na comunicação social, que 40, 1 milhões de americanos vivem abaixo da linha de pobreza.

9. O recurso às políticas orientadas para provocar a baixa dos salários reais tem sido o principal expediente utilizado para tentar contrariar a tendência

187 Cfr. W. C. PETERSON, ob. cit..

188 Dados colhidos em Sam PIZZIGATI, http://toomuchonline.org/ExecScouboard.html (29.10.2011).

189 Cfr. F. GOLDSTEIN, ob. cit., 8. A diminuição da percentagem dos rendimentos do trabalho é ainda mais acentuada se deixarmos de fora os advogados de negócios, os gestores profissionais, o reduzido núcleo (1\%) dos 'colaboradores' mais bem pagos, que, no grande banquete do capital, se sentam à mesa com os maiores acionistas das grandes sociedades anónimas. Tomando apenas os EUA, dados da OCDE indicam que os 25\% dos salários mais baixos diminuíram 31\% entre 1980 e 2005, enquanto os salários dos 10\% do topo da escala aumentaram 21\%. Cfr. E. STOCKHAMMER, ob. cit., 10/11. 
estrutural no sentido da baixa da taxa de lucro. Mas a verdade é que o salário pago aos trabalhadores não é apenas um elemento dos custos de produção. É também o rendimento que alimenta o poder de compra da grande maioria da população que há-de comprar as mercadorias que foram produzidas com o único objetivo de serem vendidas no mercado e que têm de ser vendidas para que os empresários capitalistas possam recuperar o dinheiro investido e apoderar-se da mais-valia (em linguagem marxista).

Por isso, a diminuição do poder de compra dos trabalhadores não pode ser inteiramente compensada pelo aumento do consumo de luxo e de superluxo dos ricos. Esse aumento - que se tem, aliás, registado, de forma explosiva, 'queimando' para investimentos produtivos e investimentos sociais uma parte significativa da riqueza criada - não basta (como já Henry Ford e Keynes tinham percebido) para assegurar uma procura agregada que acompanhe o aumento da capacidade de produção. A sociedade de produção em massa exige um consumo de massa.

Pode aumentar a pressão consumista, usando e abusando dos instrumentos ao serviço da sociedade de consumo. Mas isso também não basta: a tentativa de compensar a redução do poder de compra dos salários através do estímulo ao consumo financiado pelo crédito (credit-financed-consumption) não chega para anular os efeitos daquela redução, e provoca a baixa generalizada e acentuada da taxa de poupança das famílias (e dos estados) e o sobreendividamento de muitas delas, que acabam por não poder pagar os encargos assumidos.

A crise económica e social aberta na sequência da crise financeira e da crise fiscal dela resultante veio confirmar o que já se sabia: ao reduzir os salários, o capital aumenta a sua taxa de mais-valia. Mas, ao fazê-lo, reduz o poder de compra dos trabalhadores, que constituem a grande massa dos consumidores, colocando em risco a realização da mais-valia, abrindo, deste modo, uma crise de sobreprodução. Porque as crises cíclicas inerentes ao capitalismo são, precisamente, crises de realização da mais-valia.

O predomínio do capital financeiro sobre o capital produtivo tem acentuado os riscos de crise nos setores das atividades produtivas (nomeadamente os setores industriais), com a crescente dificuldade do capital produtivo na recuperação do capital adiantado e com a acentuação da tendência para a baixa da taxa de lucro, uma vez que as rendas do capital fincanceiro (com realce para o capital especulativo) vêm absorvendo uma parte crescente da mais-valia global. 
10. Dados os elevados custos da tecnologia atualmente utilizada, as grandes empresas são forçadas a expandir a produção até ao limite da sua capacidade disponível, na tentativa de aumentar a sua quota de mercado e os seus lucros.

Mas esta tecnologia altamente sofisticada exige cada vez menos trabalhadores, que produzem cada vez mais bens por unidade de tempo de trabalho, do mesmo modo que a concorrência entre os trabalhadores à escala mundial facilita a adoção de políticas orientadas para fazer baixar os salários reais e acentua os efeitos destas políticas.

A financeirização da economia foi acompanhada (sobretudo nos EUA e na Europa) pela 'internacionalização' de muitas empresas industriais (isto é, pela exportação de capital acompanhada da deslocalização de muitas delas para países com mão-de-obra muito barata e sem direitos, como a China, Índia e outros países do chamado Terceiro Mundo). A outra face desta realidade é a acentuada desindustrialização das economias capitalistas desenvolvidas, com profundas alterações na estrutura da produção e do emprego, que têm provocado enorme debilidade nas estruturas produtivas dos países dominantes. E esta debilidade é o pano de fundo das políticas que têm vindo a pôr em causa a segurança do emprego, os níveis salariais e os direitos sociais dos trabalhadores dos países mais industrializados, e dificultando a criação de emprego no momento da ultrapassagem dos períodos de depressão.

Estudos referentes aos EUA indicam que os novos postos de trabalho criados no setor dos serviços oferecem, na sua maioria, salários bastante mais baixos do que os praticados anteriormente na indústria. E aqui pode radicar um fator estrutural gerador da baixa dos salários reais na sociedade americana, aumentando as desigualdades e potenciando a ocorrência de crises cíclicas, cada vez mais difíceis de ultrapassar, no que se refere ao desemprego, dada a redução das atividades produtivas na indústria: é mais difícil criar novos postos de trabalho e os que existem oferecem salários mais baixos.

Por outro lado, como é sabido, a concorrência entre as grandes empresas monopolistas (nos mercados de oligopólio) faz-se através da introdução de novas tecnologias de produção e de novos produtos. Mas as tentativas de ampliar por este meio as quotas de mercado atingem rapidamente os seus limites. Com efeito, o alto nível de produtividade das tecnologias disponíveis gera em pouco tempo um volume de produção que ultrapassa o poder de compra dos 
consumidores, e o processo de expansão é travado, porque ninguém investe para aumentar a capacidade de produção se souber que não pode vender, com lucro, os bens produzidos.

Por isso, nos últimos vinte ou trinta anos, as crises do capitalismo têm-se caraterizado por uma enorme dificuldade em retomar o crescimento do emprego: a economia começa a crescer, mas o desemprego mantém-se, a níveis elevados. Isto significa que, não recuperando o seu posto de trabalho, os trabalhadores não recebem o seu salário e não dispõem de rendimentos para comprar as mercadorias que o sistema produz para vender (única forma de realizar a mais-valia e obter lucros).

A ultrapassagem das crises do capitalismo vem-se revelando uma tarefa cada vez mais difícil de resolver, porque, nas condições referidas, não é fácil fazer arrancar o processo de acumulação do capital, traduzido na recuperação da economia e na criação de emprego. Apesar da enorme injeção de capitais públicos, a economia americana continuava a registar, em meados de 2011, 14 milhões de desempregados.

11. Do ponto de vista das nossas preocupações, é também importante tentar saber qual a relação entre o aumento dos lucros e o aumento do investimento, dado que, desde Adam Smith, os defensores do mercado vêm insistindo em que a salvaguarda das margens de lucro é indispensável para que haja investimento. Dentro da lógica do capitalismo, esta afirmação é verdadeira; mas isso não significa que o aumento dos lucros arraste necessariamente consigo um correspondente aumento do investimento.

$\mathrm{Na}$ verdade, a relação entre o aumento dos lucros e o nível do investimento diminuiu consideravelmente, nos países mais desenvolvidos (EUA, Reino Unido, Alemanha, França e Japão), a partir de meados dos anos $1970{ }^{190}$, período que coincide com o início da contra-revolução monetarista, que trouxe consigo o domínio do capital financeiro e a adaptação das 'regras do jogo' aos interesses dos especuladores. Os 'investimentos' a curto prazo na especulação tornaram-se mais rentáveis do que o investimento produtivo. Estava aberto o caminho

190 Cfr. E. STOCKHAMMER, ob. cit., 12/13. 
da financeirização do sistema, que afundou os grandes senhores do capital no mundo obscuro dos jogos de casino. Estes, como já se disse atrás, fizeram o resto.

Neste mesmo sentido atuou o processo de inovação financeira, a que nos referimos anteriormente. Os chamados investidores institucionais adquiriram um peso enorme no capital acionista das grandes empresas cotadas em bolsa. E este tem sido um dos fatores da financeirização das economias capitalistas, porque estes investidores têm privilegiado o 'investimento' em capital fictício (ativos financeiros), o mesmo fazendo os bancos, que têm exigido às empresas produtivas taxas de juro crescentes (capazes de se aproximar dos ganhos chorudos da especulação), realizando assim lucros elevados (quase isentos de impostos), que canalizam (bem como os depósitos dos seus clientes) para atividades puramente especulativas, quase sempre desenvolvidas por entidades com sede no ambiente acolhedor dos paraísos fiscais.

Por outro lado, as grandes sociedades anónimas e os seus managers abandonaram a prática tradicional de não distribuir uma parte dos lucros, a fim de canalizar para o financiamento do investimento produtivo esta poupança forçada dos acionistas. Ao invés, passaram a privilegiar a maximização do lucro a curto prazo e a distribuição de dividendos elevadíssimos aos acionistas, acompanhada do pagamento de generosos salários e prémios aos gestores que cumprem as metas. Uns e outros colocam este dinheiro nos paraísos fiscais (para isso os inventaram) e jogam forte nas bolsas-casino.

12. Como é sabido, no rescaldo da primeira grande crise do capitalismo ocorrida após um período de euforia especulativa, Keynes (1936) veio defender junto dos que, como ele, queriam salvar o capitalismo, a ideia de que a socialização do investimento tornaria o capital abundante e baixaria as taxas de juro para valores próximos de zero dentro de um prazo de 25 anos, provocando deste modo, gradualmente, sem necessidade de qualquer revolução, o que ele chamou a eutanásia do rendista, a morte do capitalista sem profissão ("functionless investor" - cap. XXIV da General Theory).

Mas a contra-revolução monetarista veio matar Keynes, enterrado a preceito, para que não ressuscitasse. E a cartilha neoliberal impôs, ao longo das últimas décadas, políticas deliberadamente empenhadas em criar as condições 
favoráveis à especulação e em proteger os que vivem das 'rendas' da especulação bolsista, das 'rendas' da especulação imobiliária e de todas as 'rendas' de tipo feudal garantidas pelo estado capitalista, agora na veste de estado garantidor.

Neste ambiente, a crise chegou, esperada e talvez programada.

Trata-se de uma crise do neoliberalismo, diagnosticaram alguns, com o objetivo de fazer passar a mensagem de que o capitalismo não tem que ver com as crises, que o capitalismo - com a sua famosa economia de mercado é intocável e é eterno, como eternas e universais são as leis que o governam.

A verdade, porém, é que o neoliberalismo não existe fora do capitalismo, não é um fruto exótico que nasceu nos terrenos do capitalismo, nem é o produto inventado por uns quantos 'filósofos' que não têm mais nada em que pensar. O neoliberalismo corresponde a "uma nova fase na evolução do capitalismo". ${ }^{191}$ O neoliberalismo é o reencontro do capitalismo consigo mesmo, depois de limpar os cremes das máscaras que foi construindo para se disfarçar. O neoliberalismo é o capitalismo na sua essência de sistema assente na exploração do trabalho assalariado, na maximização do lucro, no agravamento das desigualdades. O neoliberalismo é o capitalismo puro e duro do século xvıı, mais uma vez convencido da sua eternidade, e convencido de que pode permitir ao capital todas as liberdades, incluindo as que matam as liberdades dos que vivem do rendimento do seu trabalho. O neoliberalismo é a expressão ideológica da hegemonia do capital financeiro sobre o capital produtivo, hegemonia construída e consolidada com base na ação do estado capitalista, porque, ao contrário de uma certa leitura que dele se faz, o neoliberalismo exige um forte estado de classe ao serviço dos objetivos do setor dominante das classes dominantes, o capital financeiro. O neoliberalismo é a ditadura da burguesia, sem concessões. Mais especificamente: a ditadura do grande capital financeiro.

A esta luz, poderemos dizer que, em certo sentido, esta é uma crise do neoliberalismo (ou uma crise da financeirização). ${ }^{192}$ Com efeito, a contra-revolução monetarista trouxe consigo a plena liberdade de circulação de capitais à escala mundial; a independência dos bancos centrais; a desregulamentação das atividades do setor financeiro; o livre curso do processo de inovação financeira (criação

191 Cfr. G. DUMÉNIL e D. LÉVY, The Crisis..., cit., 5.

192 Uma caraterização desta crisis of financialisation pode ver-se em C. LAPAVITSAS e outros, Eurozone Crisis, cit., 4. 
de produtos derivados, mercados de futuros, todos os ingredientes das bolsas-casino); a prioridade absoluta conferida à estabilidade dos preços em detrimento do pleno emprego e do combate ao desemprego; a orientação das grandes sociedades anónimas no sentido de favorecer a distribuição de dividendos régios aos seus acionistas e de prémios principescos aos seus gestores, com prejuízo do autofinanciamento do investimento produtivo; a luta contra os sindicatos (nomeadamente contra a contratação coletiva); o aumento das taxas reais de juro cobradas pela banca e o aumento dos ganhos do setor financeiro, que se apropria de uma parte crescente da mais-valia, da riqueza criada no setor produtivo, que, por isso mesmo, é afetado pela tendência para a baixa das taxas de lucro; o aumento do endividamento das famílias, das empresas e dos estados.

E estes são elementos claramente potenciadores da ocorrência das crises cíclicas próprias do capitalismo e da crescente dificuldade em sair delas através da recuperação das taxas de lucro das empresas não financeiras, do aumento da taxa de utilização da capacidade de produção instalada, do aumento do investimento privado em atividades produtivas, e, sobretudo, através do aumento da produção e do emprego. Neste sentido, concordamos em absoluto com a tese segundo a qual "as últimas transformações do capitalismo [as que decorrem da ideologia neoliberal] podem conduzir a crises em que os mecanismos monetários e financeiros desempenham um papel central, aumentando a instabilidade inerente ao sistema. (...) Estas crises constituem uma componente maior dos custos do neoliberalismo". 193

Seja como for, a presente crise é, na sua essência, mais uma crise do capitalismo, uma "crise estrutural do capitalismo". ${ }^{194}$

As suas causas últimas, indo além das bolhas especulativas e dos jogos de casino que tornaram a crise indisfarçável, radicam na própria essência do capitalismo, tendo-se acentuado progressivamente à medida que se foram consolidando os resultados da mundialização feliz de que falam os apóstolos da política de globalização neoliberal dominante.

O ambiente especulativo atrás desenhado acentuou a volatilidade e a incerteza dos mercados financeiros (nomeadamente quanto às taxas de juro e às taxas de

193 Cfr. G. DUMÉNIL e D. LÉVY, "Costs and benefits..., cit., 602, e também C. CAMACHO e J. ROJAS NIETO, ob. cit.

194 Cfr. G. DUMÉNIL e D. LÉVY, The Crisis..., cit. 
câmbio), afetando negativamente o investimento nos setores produtivos. Se à baixa deste tipo de investimento acrescentarmos a baixa do consumo privado, o resultado é a diminuição da procura agregada.

A equação enunciada permite compreender não só a génese das situações recorrentes de sobreprodução, mas também o facto de estar a tornar-se cada vez mais difícil para o capital recuperar os adiantamentos feitos na aquisição de equipamentos muito caros, acentuando-se a tendência para a baixa da taxa de lucro.

Esta é a questão central que está por detrás da crise (desta e de todas as outras crises do capitalismo). E ela traduz uma contradição que o capitalismo não consegue ultrapassar, a contradição entre o nível de desenvolvimento das forças produtivas e a natureza das relações de produção próprias do capitalismo, que assentam no trabalho assalariado e pressupõem a maximização do lucro do capital.

13. As ideias que acabámos de enunciar não são ideias novas. O facto de elas terem sido deliberadamente 'esquecidas' pode resultar da atitude obscurantista dos fanáticos do deus-mercado, mas pode resultar também da vontade destes mesmos e de todos os setores do capital de, num quadro que consideravam favorável, desencadear uma crise, para, a coberto dela e sob o pretexto de a combater, acentuarem as políticas tendentes a aniquilar de uma vez por todas os direitos sociais dos trabalhadores (e, portanto, também os seus direitos civis e políticos), com o objetivo de fazer regressar o mundo aos tempos do capitalismo selvagem (que é, afinal, o capitalismo na sua essência).

A presente crise, fruto das desigualdades, vem agravando as desigualdades e vem alargando a pobreza (com um número cada vez maior de pobres que trabalham), confirmando o capitalismo a sua caraterística genética de "civilização das desigualdades".

Razões não faltam, como se vê, para deitar fora os catecismos neoliberais: no plano teórico, o neoliberalismo está completamente desacreditado, e os resultados das políticas neoliberais são consabidamente desastrosos. A verdade, porém, é que o neoliberalismo não saiu de cena: os pontos deste 'teatro do mundo' continuam a soprar aos atores em palco os mesmos textos... E os governantes de 
turno não conhecem outra cartilha. Infelizmente, até hoje a realidade confirma este diagnóstico.

Esta não será a última crise do capitalismo, mas ela ajudará a enfraquecer ainda mais este corpo condenado a morrer (como tudo o que é histórico) e a dar lugar a um mundo diferente, apesar de todos os meios - e são muitos - que podem ainda prolongar-lhe a vida.

O feudalismo deu o lugar ao capitalismo quando, ao fim de um longo período de desagregação, aquele modo de organização económico-social se revelou incapaz de garantir as rendas que sustentavam o estatuto privilegiado das classes dominantes, que já não tinham mais margem para aumentar a exploração dos trabalbadores servos. Talvez se aproxime o tempo em que as contradições do capitalismo começam a revelar a sua incapacidade para manter as rendas (verdadeiras rendas feudais) do capital financeiro. A menos que, esgotada a possibilidade de novas exigências aos trabalbadores assalariados, se recorra, uma vez mais, à barbárie extrema.

Há mais de cinquenta anos, o argentino Raúl Prebisch (o primeiro Presidente da agência da ONU Comissão Económica para a América Latina) avisou que as soluções liberais só podem concretizar-se manu militari. No início dos anos 1980, Paul Samuelson chamava a atenção para os perigos do "fascismo de mercado". Mais recentemente Paul Krugman recordava: "Somos uma sociedade em que a concentração do rendimento e da riqueza nas mãos de poucas pessoas ameaça fazer com que sejamos uma democracia somente de nome (...), uma vez que a concentração extrema do rendimento é incompatível com a democracia real". ${ }^{195}$

Se tivermos presente esta lição, compreendemos que a luta contra o neoliberalismo e contra as políticas nele inspiradas é uma luta pela democracia. E esta luta trava-se hoje também no terreno do trabalho teórico (que nos ajuda a compreender a realidade para melhor intervir sobre ela) e no terreno da luta ideológica, porque o peso dos aparelhos ideológicos ao serviço da ideologia dominante é hoje talvez o fator mais importante na determinação da correlação de forças que decide as lutas sociais e porque a luta ideológica é, hoje mais do que nunca, um fator essencial da luta política e da luta social (da luta de classes).

195 Artigo no New York Times, 7.11.2011. 
Parafraseando um poeta brasileiro (Álvaro Moreyra), uma coisa parece hoje incontestável: este mundo está todo errado. É preciso passá-lo a limpo. Aos universitários e aos intelectuais em geral cabe, como cidadãos, como universitários e como intelectuais, uma responsabilidade enorme nas lutas a travar nestes domínios, para que um dia, como nos diz a canção de Xico Buarque, possa nascer uma flor no "impossível chão". 


\section{BIBLIOGRAFIA}

AVELÃS NUNES, António José - Economia, Vol. II, O Crédito (Lições aos alunos do $5^{\circ}$ ano da FDUC), edição dos Serviços de Acção Social da Universidade de Coimbra, Coimbra, 2006.

BARROSO, Alfredo - "A crise da social-democracia europeia", em Le Monde Diplomatique (ed. port.), no 61, novembro/2011, 16/17.

CAMACHO, Carlos Morera e NIETO, José Antonio Rojas - "The Globalisation of Fnancial Capital, 1997-2008", em http://researchonmoneyandfinance.org, 15 março/2009.

CARVAlHO, Pedro - "A Crise por detrás da(s) Crise(s). Reflexões sobre a evolução do sistema capitalista do século xix à Grande Depressão", em Vértice, n 152, maio-junho/2010, 81-99.

CASSEN, Bernard e outros (Coord.), Contra a ditadura dos mercados, trad. port., Campo da Comunicação, Porto, 2000.

CASSIDY, John - How Markets Fail - The Logic of Economic Calamities, Londres, Allen Lane/Penguin Books, 2009.

CROTTY, James - "The Neoliberal Paradox: The Impact of Destructive Product Market Competition and Impatient Finance Nonfinancial Corporations in the Neoliberal Era", em Review of Radical Political Economics, Vol. 35, n 3 (2003), 271-279.

DUMÉNIL, Gérard e Dominique LÉVY - "Costs and benefits of neoliberalism. A class analysis", em Review of International Political Economy, Vol. 8, no 4, Inverno/2001, 578-607 ; - "The profit rate: where and how much did it fall? Did it recover? (USA 1948-2000), em Review of Radical Political Economics, vol. 34 (2002), 437-461;

- The Crisis of Neoliberalism, Harvard University Press, 2011.

GALBRAITH, James K. - Introdução à tradução brasileira de John Kenneth GALBRAITH, 1929 - A Grande Crise, Larousse do Brasil, São Paulo, 2010, 9-14.

GALLIN, Dan - "Reinventar a política sindical", em B. CASSEN e outros (Coord.), ob. cit., 101-122.

GOLDSTEIN, Fred - "Capitalism in Crisis" (outubro/2010), disponível em www.lowwagecapitalism.com

GREEN, David G. - The New Conservatism - The counter revolution in political, economic and social thought, St. Martin's Press, New York, 1987.

GREENSPAN, Alan - A Era da Turbulência - Aventuras em um novo mundo, trad. bras., Elsevier Editora/Campus, São Paulo, 2008.

HAYEK, Friedrich - "Unions, Inflation and Profits" (original de 1959), em F. HAYEK, Studies in Philosophy, Politics and Economics (1 $1^{\mathrm{a}}$ edição, 1967), Routledge and Kegan Paul, Londres, 1978.

HUSSON, Michel - "Uma forma exacerbada de rendibilizar o capital", em B. CASSEN e outros (Coord.), ob. cit., 51-53. 
IMBERT, Pierre-André - "Todo o poder aos fundos de pensões", em B. CASSEN e outros (Coord.), ob. cit., 41-47.

KELLY, Marjorie - The Divine Right of Capital, Berrett-Koehler, San Francisco, 2001.

LAPAVITSAS, C., A. Kaltenbrunner, D. Lindo e outros - "Eurozone Crisis: Beggar Thyself and Thy Neighbour", RMF occasional report, março/2010, em www.researchonmoneyandfinance.org.

PETERSON, Wallace. C. - "The Silent Depression", em Challenge, no de julho-agosto/1991 [utiliza-se a versão publicada em Problèmes Économiques, no 2.271, 15.4.1992, 1-6].

QUELHAS, José Manuel Gonçalves Santos - Sobre as Crises Financeiras, o Risco Sistémico e a Incerteza Sistemática, Tese de Doutoramento, Coimbra, 2009.

STERN, Gary H. and FELDMAN, Ron J. - Too Big to Fail - The Hazards of Bank Bailouts, Washington, Brooking Institution Press, 2009.

STOCKHAMMER, Engelbert - "Neoliberalism, Income Distribution and the Causes of the Crisis", em http://researchonmoneyandfinance.org, versão 0.6:17 junho 2010. 
Alain de Benoist

Diretor das revistas Nouvelle Critique e Krisis

\section{Aux origines de la Crise financière}

On dit souvent que le capitalisme est synonyme de crise, qu'il se nourrit des crises qu'il provoque, ou encore que sa "faculté d'adaptation" est sans limites, laissant ainsi entendre qu'il est indestructible. En réalité, il faut distinguer les crises cycliques, conjoncturelles, et les crises systémiques, structurelles (comme celles qui ont eu lieu entre 1870 et 1893, puis lors de la Grande Dépression de 1929-30, ou encore entre 1973 et 1982, lorsqu'un chômage structurel a commencé à apparaître dans les pays occidentaux).

Les cycles économiques, qui ont été décrits par des économistes comme Nicolas Kondratieff (mort en 1930) ou Joseph Schumpeter (mort en 1950), s'inscrivent dans ce que l'historien Fernand Braudel appelait le temps de la "longue durée». Les cycles mis en évidence dès 1926 par Kondratieff sont des cycles de l'ordre de 40 à 60 ans, qui se décomposent en deux phases. Dans la phase ascendante, les profits sont fondamentalement générés par la production, tandis que dans la phase B, le capitalisme, pour continuer à faire augmenter les profits, doit se financiariser. Les capitaux deviennent de plus en plus des titres de spéculation sur l'avenir, perdant leur fonction d'investissements nécessaires au travail.

La phase A, caractérisée par l'invention et la diffusion d'innovations nombreuses, s'accompagne progressivement d'un excès d'investissements, réalisé pour faire face à la concurrence, ce qui provoque une hausse des prix et des taux d'intérêts, prélude à un retournement du cycle. Dans la phase $\mathrm{B}$, descendante, on assiste à un endettement massif tant de la part des Etats que des ménages. Parallèlement à la suraccumulation du capital, le renforcement du pouvoir financier devient le levier déterminant de toute stratégie visant à augmenter la rentabilité du capital. Au stade final, les «bulles» spéculatives explosent les unes après les autres, le 
chômage augmente, les faillites se multiplient, etc. Dans un climat de destruction générale de la valeur (élimination des stocks, fermeture des entreprises et des filières les moins rentables), l'économie se retrouve en état de déflation réelle. Le système devient alors chaotique et incontrôlable, les troubles politiques et sociaux venant encore aggraver la situation.

Nombre d'économistes pensent que nous sommes aujourd'hui dans la phase B d'un cycle entamé il y a environ 35 ans, et que la crise financière mondiale qui s'est ouverte aux Etats-Unis à l'automne 2008 est bien une crise structurelle, correspondant à une rupture de la cohérence dynamique de l'ensemble du système. Venant après les crises pétrolières de 1973 et 1979, la crise de la dette bancaire des pays en voie de développement de 1982, la crise du marché des actions et des taux d'intérêt de 1987, la récession américaine de 1991, la crise asiatique de 1997, l'explosion de la bulle des valeurs Internet de 2001, cette crise, beaucoup plus forte que les précédentes, est incontestablement la plus grave que l'on ait connue depuis les années 1930. D’autant qu'elle se déroule dans un univers désormais mondialisé.

C'est en fait à une triple crise que nous nous trouvons confrontés: crise du système capitaliste, crise de la mondialisation libérale, crise de l'hégémonie américaine.

L'explication la plus souvent avancée pour interpréter les origines de la crise actuelle est l'endettement des ménages américains par le biais des prêts hypothécaires immobiliers (les fameux «subprimes»). Ce n'est pas faux, mais on oublie de dire pourquoi ils se sont endettés.

L'éternel problème du capitalisme est celui des débouchés. A l'origine, le capitalisme cherchait à vendre toujours plus à des gens qu'il tendait toujours plus à priver des moyens d'acheter. D’un côté, il se félicitait de voir augmenter ses bénéfices au détriment des revenus du travail, de l'autre il voyait bien qu'en dernière analyse, il fallait bien que la consommation progresse pour que ses profits continuent d'augmenter. Or, baisser les salaires, c'est aussi faire baisser la consommation. Dans la phase fordiste, on avait réalisé qu'il ne servait à rien d'augmenter sans cesse la production si les gens n'avaient pas les moyens de l'acheter. On a donc progressivement augmenté les salaires à seule fin de soutenir la consommation. C'est de cette phase, qui a connu son apogée à l'époque des «Trente Glorieuses», que l'on est en train de sortir. Dans ce que Frédéric Lordon a appelé le "capitalisme de basse pression salariale», on abandonne 
progressivement la logique fordiste, qui reposait sur l'idée qu'il fallait augmenter régulièrement les salaires afin d'alimenter et soutenir la consommation, et l'on en revient au capitalisme initial, où la répartition des revenus entre le capital et les salariés s'interprétait comme un jeu à somme nulle: tout ce qui était gagné par les uns était perdu par les autres.

Comment retrouver des débouchés quand la profitabilité des investissements tend à baisser, c'est-à-dire quand on assiste à une baisse tendancielle du taux de profit? Une première solution est l'allongement du temps de travail, mais l'augmentation de revenus qui en résulte est toute relative, d'autant que le prix de l'unité de temps travaillé n'est évidemment pas revalorisé (on doit travailler plus, mais toujours au même tarif). L'obligation de travailler plus, de travailler le dimanche, de faire des heures supplémentaires, etc., a par ailleurs des effets pervers sur la vie quotidienne: moins de loisirs, moins de temps à consacrer à sa vie familiale ou à ses enfants. Une seconde solution consiste à recourir à une main-d'œuvre à bon marché, peu qualifiée mais également peu revendicative. C'est ce qui explique pourquoi le patronat a toujours favorisé l'immigration, en considérant les immigrés comme une armée de réserve du capital permettant de peser à la baisse sur les salaires des autochtones.

La troisième solution, qui est celle à laquelle le capitalisme a eu massivement recours depuis la Deuxième Guerre mondiale, et surtout depuis les années 1980, est le crédit. Si les gens s'endettent, ils disposeront de plus de moyens et pourront donc plus consommer. Le problème, dans ce schéma de soutien à la consommation par le crédit, est évidemment que les gens sont censés rembourser leurs dettes - et qu'ils n'y parviennent plus, précisément, dès lors que leurs revenus stagnent ou diminuent. C'est l'une des composantes majeures de la crise actuelle. Aux Etats-Unis, le taux d'endettement moyen des ménages (le ratio de leur endettement total par rapport à leur revenu disponible) était en 2008 de 120 \%. Le taux d'endettement a également explosé dans la plupart des autres pays occidentaux, ce surendettement s'ajoutant à la dette publique et à l'endettement des entreprises. D'où la situation explosive que l'on connaît.

Le salaire est aujourd'hui écrasé entre deux types de contraintes: d'une part, la contrainte actionnariale, et de l'autre la contrainte concurrentielle.

L'un des traits dominants du "turbo-capitalisme», correspondant à la troisième vague de l'histoire du capitalisme, est la complète domination des marchés 
financiers. Cette domination donne un pouvoir accru aux détenteurs du capital, et plus particulièrement aux actionnaires, qui sont aujourd'hui les véritables propriétaires des sociétés cotées en Bourse. Désireux d’obtenir un rendement toujours plus élevé et plus rapide de leurs investissements, les actionnaires poussent à la compression des salaires et à la délocalisation opportuniste de la production vers des pays émergents où la hausse de la productivité va de pair avec de très bas coûts salariaux. Parallèlement, les entreprises tentent d'obtenir un meilleur taux de productivité en employant toujours moins d'hommes, ce qui entraîne des destructions d'emploi. L'augmentation de la valeur ajoutée profitant aux revenus du capital plus qu'aux revenus du travail, la déflation salariale se traduit par la stagnation ou la baisse du pouvoir d'achat, et la diminution de la demande solvable globale. La concurrence, de son côté, s'exprime en termes nouveaux à l'époque de la mondialisation: les délocalisations, qui mettent en concurrence les salariés des pays développés avec des hommes qui, à l'autre bout du monde, exécutent le même travail à des tarifs de dumping absolu, la font en effet s'exercer dans des conditions objectivement déloyales.

Le résultat final est que le salaire devient quasiment une variable d'ajustement macro-économique, et que les destructions d'emplois se multiplient. La stratégie actuelle des maîtres du Capital est donc de comprimer toujours plus les salaires, d'aggraver toujours plus la précarité du marché du travail, produisant ainsi une paupérisation relative des classes populaires et des classes moyennes qui, dans l'espoir de maintenir leur niveau de vie, n'ont d'autre ressource que de s'endetter, alors même que leur solvabilité réelle ne cesse de diminuer.

La possibilité offerte aux ménages d'emprunter pour couvrir leurs dépenses courantes ou acquérir un logement a été l'innovation financière majeure du capitalisme d'après-guerre. Les économies ont alors été stimulées par une demande artificiellement fondée sur les facilités du crédit. Outre-Atlantique, cette tendance a été encouragée depuis les années 1990 par l'octroi de conditions de crédit de plus en plus favorables, sans aucune considération de la solvabilité des emprunteurs. On a ainsi cherché à compenser la baisse de la demande solvable résultant de la compression des salaires par l'emballement de la machine à crédit. En d'autres termes, on a stimulé la consommation à travers le crédit, faute de pouvoir la stimuler par l'augmentation du pouvoir d'achat. C'était là le seul moyen, pour les détenteurs de portefeuilles 
financiers, de trouver de nouveaux gisements de rentabilité, fût-ce au prix de risques inconsidérés.

D’où le surendettement pharamineux des ménages américains qui ont depuis longtemps choisi de consommer plutôt que d'épargner (les ménages américains sont aujourd'hui deux fois plus endettés que les ménages français, trois fois plus endettés que les ménages italiens). Après quoi, on a spéculé sur ces "créances pourries" par le biais de la "titrisation», qui a permis aux grands acteurs de la sphère du crédit de se décharger, en les rendant liquides, des risques d’insolvabilité de leurs emprunteurs. La "titrisation», qui est une autre des innovations financières majeures du capitalisme d'après guerre, consiste à découper en tranches, dites obligations, les prêts accordés par une banque ou une société de crédits, puis à en revendre le montant, c'est-à-dire le risque, à d'autres agents financiers appartenant au monde des fonds de placement. Il se crée ainsi un vaste marché du crédit, qui est aussi un marché du risque. C'est ce marché qui s'est effondré en 2008. L'emballement des mécanismes du crédit, qui ont techniquement déclenché la crise aux Etats-Unis, résulte donc de la tentative du capital de maintenir la capacité de consommation du plus grand nombre alors que les salaires et les revenus du travail étaient de plus en plus mis sous pression. La crise actuelle s'est ouverte quand le crédit s'est évaporé. La mégalomanie et la cupidité inouïe des hauts dirigeants des grandes sociétés et des grandes banques commerciales ou d'affaires ont fait le reste.

Mais c'est aussi à une crise de la mondialisation libérale que l'on assiste. La transmission brutale de la crise hypothécaire américaine aux marchés du monde entier est le fruit direct d'une globalisation conçue et réalisée par les apprentis sorciers de la finance. Au-delà de sa cause immédiate, elle constitue l'aboutissement de 40 ans de déréglementation voulue par un modèle économique mondialisé selon les recettes libérales. C'est en effet l'idéologie de la dérégulation qui a rendu possible le surendettement américain, tout comme elle avait déjà été à l'origine des crises mexicaine (1995), asiatique (1997), russe (1998), argentine (2001), etc. La globalisation, en même temps qu'elle rendait possible toutes sortes de délocalisations, a renforcé l'organisation concentriques des marchés financiers autour du pôle américain. Elle permet également aux capitaux de circuler sans contrôle d'un bout à l'autre de la planète. Elle donne ainsi aux marchés financiers, eux aussi mondialisés et complètement déterritorialisés, une position dominante, 
ce qui renforce la financiarisation du capital par rapport à l'économie réelle: la monnaie n'étant plus émise proportionnellement à la richesse créée (la somme des biens et des services produits), d'immenses masses financières virtuelles tournent à une vitesse croissante autour du globe à la recherche d'un investissement rentable ou d'une incarnation durable. La globalisation, enfin, a créé une situation dans laquelle les crises majeures qui se produisent en l'un ou l'autre point de la Terre se propagent désormais presque instantanément, de façon «virale» aurait dit le sociologue Jean Baudrillard, à l'ensemble de la planète. C'est pourquoi la crise américaine a touché aussi vite les marchés financiers européens, à commencer par les marchés du crédit, avec toutes les conséquences que pouvait avoir une pareille onde de choc à un moment où l'économie américaine comme celle de l'Europe étaient déjà au bord de la récession.

On ne doit pas perdre de vue, enfin, que cette crise mondiale a sa source aux Etats-Unis, c'est-à-dire dans un pays qui doit déjà faire face à un déficit budgétaire abyssal, une dette extérieure qui ne cesse de croître et un déficit commercial colossal. Depuis dix ans, l'économie américaine n'a plus pour moteur la croissance due à la production réelle, mais l'expansion de la dette et la rente monétaire résultant de la domination mondiale du dollar.

Le fait que le dollar soit à la fois une monnaie nationale et une unité de compte internationale, qui plus est libérée de tout lien avec l'or depuis 1971, a longtemps permis aux Etats-Unis d'affirmer et de faire peser leur hégémonie tout en continuant d'enregistrer des déficits colossaux. Le procédé a consisté pour les Américains à exporter systématiquement leurs titres de dettes vers des pays excédentaires. A l'avenir, l'inquiétude des grands fonds publics et privés qui, notamment en Asie, détiennent des quantités considérables de titres publics et parapublics américains (bons du Trésor, etc.), et donc autant de créances sur les Etats-Unis, sera déterminante. A l'heure actuelle, 70 \% de toutes les réserves étrangères dans le monde sont constituées en dollars, cette masse n'ayant plus depuis longtemps le moindre rapport avec le volume réel de l'économie américaine. Dans les années qui viennent, il n'est pas impossible que les pays exportateurs de pétrole abandonnent peu à peu le dollar (les fameux "pétrodollars») pour l'euro. A long terme, cette situation pourrait aboutir à ce que des pays comme la Chine et la Russie postulent à des responsabilités financières internationales, voire à ce qu'ils se concertent pour concevoir un projet alternatif à l'ordre financier 
international actuel. George Soros, au printemps 2008, le disait sans ambages: "Le monde fonce vers la fin de l'ère du dollar".

On assure maintenant qu'il suffirait de «réguler» ou de «moraliser» le système pour éviter ce genre de crises. Les hommes politiques parlent volontiers de "dévoiement de la finance», tandis que d'autres stigmatisent l'«irresponsabilité» des banquiers, laissant ainsi entendre que la crise n'est due qu'à une insuffisance de réglementation et qu'un retour à des pratiques plus «transparentes» permettrait de faire revenir sur la scène un capitalisme moins carnassier. C'est une double erreur. D'abord, parce que c'est précisément l'impuissance des politiques à faire face à la crise d'efficacité du capital qui a ouvert la voie à la libéralisation totale du système financier. Ensuite et surtout, parce que c'est ignorer que la nature même du capitalisme en fait un système étranger à toute considération "morale». "Le capital ressent toute limite comme une entrave», disait déjà Karl Marx. La logique de l'accumulation du capital, c'est l'illimitation, le refus de toute limite, l'arraisonnement du monde par la raison marchande, la transformation de toutes les valeurs en marchandises, le Ge-stell dont parlait Heidegger.

Dans les phases de suraccumulation du capital, le renforcement du pouvoir financier devient le levier déterminant de toute stratégie visant à augmenter la rentabilité du capital. Mais au-delà de la seule finance, c'est en fait la régulation de l'économie toute entière par le seul critère du taux de profit, sans considération des facteurs humains, des emplois détruits, des vies broyées, de l'épuisement des ressources naturelles, des coûts non marchands (les «externalités négatives»), qui est mise en question par la crise financière. La cause finale de cette crise, c'est la recherche du profit financier le plus élevé possible dans le minimum de temps possible, en clair la recherche de l'augmentation maximale de la valeur des capitaux engagés à l'exclusion de toute autre considération.

Que va-t-il se passer maintenant? On le sait, depuis que les Etats ont refinancé les banques pour les empêcher de couler, le problème de la dette privée a débouché sur le problème de la dette publique. Par un effet de «dominos», la crise peut-elle entraîner à terme des défauts de paiement en chaîne de tous les agents économiques, et donc un effondrement de tout le système financier mondial? On n'en est pas encore là. Mais dans le meilleur des cas, la crise économique va durablement se maintenir, avec une récession généralisée, qui provoquera une remontée du chômage. Il devrait en résulter une baisse importante des profits, 
qui se répercutera inévitablement sur les marchés et les cours de la Bourse. Contrairement à ce que certains prétendent, le sort de l'économie spéculative conditionne directement celui de l'économie réelle. Les entreprises dépendent en effet du système bancaire, ne serait-ce que pour le crédit dont elles ont besoin pour leurs investissements. Or, la crise fait que les banques, fragilisées par l'accumulation de mauvaises dettes, réduisent aujourd'hui brutalement leurs crédits (c'est le "credit-crunch»).

En fait, soit on "assainit» le système pour lui permettre de repartir comme avant, auquel cas la contrainte actionnariale et la contrainte concurrentielle continueront à peser à la baisse sur les salaires, et l'on assistera dès que ce sera possible à un nouveau surendettement généralisé qui aboutira à une nouvelle crise de magnitude encore plus forte, soit on met sous contrôle la dette des ménages, mais alors la consommation baissera et la croissance ralentira, ce qui représente une perspective intolérable pour le Capital. Dans le passé, ce sont les guerres qui ont permis de sortir de ce genre de situation (dans le cas de la Deuxième Guerre mondiale, ce n'est pas comme on le croit souvent le New Deal qui a sorti les Etats-Unis de la dépression et du chômage de masse, mais bien la guerre qui transforma ce pays en atelier militaire des puissances alliées). Est-ce dans cette direction que s'orientera l'Amérique pour ne pas perdre sa suprématie mondiale?

Les Etats-Unis, qui vivent à crédit depuis longtemps, ont aujourd'hui accumulé une dette publique qui excède 11000 milliards de dollars, soit environ 36000 dollars par habitant. S'y ajoutent 50000 milliards de dettes privées (ménages et entreprises). Au total, chaque citoyen américain est endetté pour plus de 200000 dollars! Ce gonflement de la dette entraîne une augmentation corrélative de la masse monétaire, alors même que le pays qui émet cette monnaie est en récession, produit moins de richesses et s'endette chaque jour un peu plus. Quant au chômage, son taux réel a déjà dépassé les 10 \%, et l'on sait déjà que, malgré les réformes engagées par le président Obama, le nombre d'habitants dépourvus de toute protection sociale atteindra bientôt les 100 millions de personnes, soit un citoyen américain sur trois. Dans ce pays, où la reprise exigerait à la fois une baisse de la consommation, une augmentation de l'épargne privée et une réduction des déficits, le système bancaire est en réalité d'ores et déjà devenu quasiment insolvable. 
On compare souvent cette crise à celle de 1929. Elle est en réalité plus grave, pour au moins trois raisons. D'une part, il s'agit de la première vraie crise financière mondiale (la crise de 1929, souvent présentée comme telle, était en fait limitée aux Etats-Unis et à l'Europe), son ampleur reflétant la réalité même de la globalisation qui s'est mise en place depuis l'effondrement du système soviétique. D’autre part, nos sociétés dépendent beaucoup plus de la sphère financière qu'autrefois, dans la mesure où le crédit à la consommation a été depuis les années 1980 la clé de la croissance du produit national brut (PNB). Enfin, les Etats-Unis, qui étaient encore une puissance ascendante en 1929, sont aujourd'hui sur le déclin, alors qu'ils sont l'épicentre de la crise.

L'effondrement du système soviétique a résulté dans le passé d'un crise systémique. Peut-il en aller de même du système capitaliste? Certains le pensent, tel par exemple l'économiste Immanuel Wallerstein, pour qui «nous sommes entrés depuis trente ans dans la phase terminale du système capitaliste», car le capitalisme ne parvient plus à "faire système», c'est-à-dire à retrouver l'équilibre après avoir trop dévié de sa situation de stabilité. Wallenstein va jusqu'à évoquer une période de transition comparable à celle qui a vu l'humanité européenne passer du système féodal au système capitaliste. Sans aller jusque là, ce que l'on peut dire, c'est que le système de Bretton Woods (1944) connaît actuellement sa phase terminale.

Or, en dépit des proclamations du G20, les dirigeants mondiaux persistent à faire comme si le système financier mondial était seulement victime d'une crise de croissance, d'une panne passagère, auxquelles on pourrait remédier par la mise en place d'une "gouvernance financière mondiale» se traduisant par quelques mesures de "régulation", l'injection massive de nouvelles liquidités, l'octroi de nouveaux moyens au Fonds monétaire international (FMI), une baisse des taux d'intérêt, des plans de rachat des «actifs bancaires toxiques» et des "produits spéculatifs pourris» (qui ne font que repousser en direction de l'Etat, et de la dette publique, le coût de la sortie de crise), des plans de relance des industries menacées de faillite, une mise en cause superficielle des "paradis fiscaux", etc. La façon dont ces dirigeants ont unanimement condamné le protectionnisme et affirmé que la mondialisation devait à tout prix se poursuivre, montre qu'ils n'ont nullement pris conscience du caractère systémique et historique de cette crise, qui marque aussi la faillite du projet de "nouvel ordre mondial» formulé 
dans les années 1990. Ces mesures sont en outre vouées à l'échec, puisque les pays qui encourent un important déficit courant devront, pour respecter leurs engagements en matière de dette, dégager un jour ou l'autre des excédents qu'ils sont aujourd'hui incapables d'obtenir, sinon en suscitant une contraction de la demande intérieure équivalant à une récession profonde et durable, surtout lorsque leurs capacités d'exportation s'amoindrissent du fait de l'affaiblissement de leur compétitivité. En réalité, il y a tout lieu de penser que les centaines de milliards de dollars ou d'euros créés ex nihilo par les banques centrales ne génèreront que de nouvelles «bulles» encore plus monstrueusement nocives que les précédentes. Le risque est alors très grand que l'on crée les conditions, non d'une nouvelle croissance, mais d'une hyperinflation, censée effacer la dette mais qui, dans un climat de dépression généralisée, aboutira en fait à la mise en cessation de paiement de nombreux Etats, à l'explosion mondiale du chômage, à l'effondrement brutal possible de l'ensemble des systèmes de retraite par capitalisation (les célèbres fonds de pension), et surtout, quand les Etats-Unis seront dans l'obligation de monétariser leurs dettes colossales que l'étranger ne voudra plus financer comme il l'a fait jusqu'à présent, l'effondrement définitif du dollar.

En définitive, la crise que nous connaissons aujourd'hui n'est pas seulement une crise financière et bancaire, ni même simplement une crise économique. C'est une crise systémique du régime d'accumulation propre à la phase actuelle du capitalisme, qui marque également le point culminant de ce que l'on pourrait appeler, d'un point de vue philosophico-historique, la dialectique de l'avoir.

Ce sont là toutes les raisons pour lesquelles, à mon sens, la crise actuelle est loin d'être terminée. 


\section{Índice Onomástico}

Anderson, A., 224

Antoine, A., 62

Arendt, H., 14, 15, 23, 37, 38, 39

Aristóteles, 26, 27, 28, 122, 151, 152, 190

Aron, R., 143, 145

Arrighi, G., 142

Attali, J., 234

Avelãs Nunes, A. J., 17, 18, 213

Aznar, H., 207

Babo, I., 136

Babo, M. A., 184

Baker, E., 170

Barroso. A., 234

Baudrillard, J., 258

Bell, D., 145

Benjamin, W., 15

Benoist, A., 17, 18, 253

Best, S., 109, 112

Biran, M., 15, 60, 61, 62, 63, 64, 65, 67

Birkerts, S., 95, 96, 97, 98, 99, 100, 101, 102, 103

Blankenburg, E., 127, 130, 131, 132, 133, 134

Blumler, J. G., 168

Bobbio, N., 120, 121, 127, 139

Bolaño, C., 160

Boltanski, L., 147, 148, 149

Bonville, J., 165, 166, 176

Bouvier, J., 199, 200

Braudel, F., 253

Brower, B., 178

Brown, W., 145
Butler, J., 152

Camacho, C., 247

Camdessus, M., 222

Camponez, C., 17, 18, 19, 159, 169, 175, 177

Capote, T., 178, 179, 181, 182

Cardoso, G., 194, 195, 203, 204

Carr, N., 15, 93, 94, 95, 96, 100

Carvalho, P., 220

Castells, M., 159, 194, 195

Catroga, F., 49, 50

Cavarero, A., 152

Cebrián, J. L., 183

Ceia, C., 180

Charron, J., 165, 166, 176

Chartier, R., 205

Chiapello, E., 147, 148, 149

Chirac, J., 222

Chklovski, V., 180

Colombo, F., 194

Comte, A., 28

Correia, F., 167

Couldry, N., 150, 151, 152, 154, 156

Crotty, J., 223, 224, 225

Cunha, A. G., 120

Dahlberg, L., 180

Debord, G., 205

Debray, R., 204

Delporte, C., 177

Dini, L., 222

Dobel, P., 124 
Duménil, G., 214, 220, 246, 247

Dumont, L., 36

Eco, U., 183, 184

Elliot, D., 185

Esposito, R., 42

Esteves, J. P., 15, 16, 105

Ferenczi, T., 176, 177

Ferin, I., 16, 119, 124

Ferry, J.-M., 111

Feyel, G., 170

Fidalgo, A., 15, 93

Fidalgo, J., 166, 167, 175

Figueira, J. J., 17, 177, 193

Filmer, R., 80

Ford, H., 242

Frank, T., 146

Fraser, N., 148, 149, 150, 152, 156

Friedman, M., 142, 144, 208

Fulton, H., 188

Gadamer, H. G., 29, 30, 37, 38

Galbraith, J., 232, 233

Gallin, D., 236

Gambetta, D., 123

Garnham, N., 159

Gil, J., 15, 43, 44

Gilligan, C., 152, 153

Gillmor, D., 166

Goffman, E., 112

Goldstein, F., 241

Gorz, A., 160, 163

Gramsci, A., 147, 153

Greenspan, A., 216, 221, 226, 227, 228, 229, 233, 237, 238

Gross, B., 17

Grossberg, L., 142, 154

Gurevitch, M., 168

Habermas, J., 107, 115, 146

Halimi, S., 230

Hall, S., 112, 114

Harvey, D., 146

Hayek, F., 142, 143, 155, 235

Heidegger, M., 36, 65, 259
Heidenheimer, J., 124, 126, 136

Hirschman, A., 10

Hobbes, T., 78, 79, 80, 81, 82

Hölderlin, F., 14

Honneth, A., 150, 152

Husserl, E., 73, 74, 75, 76

Husson, M., 235

Imbert, A., 235

Innerarity, D., 15, 67

Johnston, M., 124, 126, 136

Jonas, H., 103

Judt, T., 14, 23, 24, 25, 26, 35

Kant, 32, 46, 58, 80, 82, 95

Kellner, D., 109, 112

Kelly, M., 223

Keynes, J. M. ,213, 214, 219, 234, 238, 239, 242, 245

Kissinger, H., 220

Klein, N., 144

Kondratieff, N., 253

Koselleck, R., 32, 35, 41, 65

Kovach, B., 195, 204, 208

Kramer, M., 181, 182

Krugman, P., 146, 249

Kuhn, T., 35, 58, 101

Kumar, K., 159

Labov, W., 187

Lacouture, J., 205

Landsberg, P., 34, 35, 59, 64

Lapavitsas, C., 231, 233, 246

Le Goff, J., 205

Leblanc, G., 135

Leibniz, 78

Lenine, 236

Lévy, D., 214, 220, 246, 247

Lippmann, W., 142, 143, 155

Lipset, S. M., 145

Lloyd, J., 155

Locke, J., 79

Lourenço, E., 54

Luke, T., 108

Mailer, N., 178, 182 
Major, J., 222

Malthus, T., 213

Martínez Albertos, 166

Marx, K., 213, 234, 239, 242, 259

Mascolo, G., 201

McLuhan, M., 91, 95, 100

Mead, G. H., 110

Meireles, S., 165, 166

Mesquita, M., 165, 170, 176

Meyer, P., 165

Michaux, H., 208

Mills, C. W., 145

Mises, L., 143

Miterrand, F., 224

Montalban, M. V., 159

Moreira, V., 170

Morgan, T. B., 178

Mouffe, C., 45, 46

Mounier, E., 34, 35, 55, 59, 64

Neunhöffer, G., 153

Nies, G., 168

Nietzsche, F., 36

Nobre Correia, 178

Pascoaes, T., 51

Pedersini, R., 168

Peet, R., 147

Peixinho, A. T., 17, 175

Pereira, M. B., 23, 27, 28, 29, 57

Pessoa, F., 50

Peterson, W. C., 241

Philp, M., 127

Picard, R., 195, 196, 197, 200, 201, 202, 203

Pinto, M., 175, 176

Platão, 27, 93

Plehwe, D., 143, 153, 154

Polanyi, M., 143

Portocarrero, M. L., 14, 23

Postman, N., 15, 68, 69, 95

Poulantzas, N., 146

Prebish, R., 249

Prince, G., 188

Prodhome, M., 170
Quelhas, J. M., 216, 226

Ramón Zallo, 164, 165

Ramonet, I., 236

Rego, A., 169

Reis, C., 187, 189

Reis, J., 7

Ricoeur, P., 14, 15, 23, 31, 32, 33, 34, 35, 36, 37, $58,59,64,65,66,68,152,184,189$

Rifkin, J., 160, 163

Rodrigues, A. D., 189

Rojas Nieto, J., 247

Rose-Ackerman, 122

Rosen, J., 185

Rosenstiel, T., 195, 204, 208

Rougier, L., 143

Rousseau, J. J., 79, 82

Sá, A. F., 15, 41

Saint-Exupéry, P., 200, 202

Sajó, A., 123

Salles, W., 239

Samuelson, P., 17, 249

Sandel, M., 208

Schechter, D., 193

Scheler, M., 34, 59, 69

Schmitt, C., 15, 45

Schumpeter, J., 253

Schütz, A., 72

Sen, A., 145

Sennett, R., 18, 160, 161, 162, 163, 169

Serrano, P., 193

Silveirinha, M. J., 16, 141

Silverstone, R., 154

Smith, A., 213, 239, 244

Stiglitz, J., 146

Stockhammer, E., 241, 244

Strange, S., 223

Sullivan, A., 153

Talese, G., 178, 179, 190

Tavares, G. M., 208

Taylor, C., 152

Taylor, J., 153

Thompson, J. B., 111, 113, 133, 136 
Tocqueville, A., 62

Tuchman, G., 185

Umbelino, L., 14, 57

Valente, V. P., 48, 49

Wallerstein, I., 261

Walpen, B., 143, 153

Weaver, D., 163, 164

Weber, M., 147, 160, 161

White, S. K., 108

Williamson, J., 143

Wolfe, T., 178, 179, 180, 182

Wolton, D., 167, 194, 198, 199

Young, T. R., 108

Zhang, L., 142

Ziegler, J., 236

Zizek, S., 146

Zoellick, R., 240 
(Página deixada propositadamente em branco) 
